Prepared in cooperation with the Miami-Dade County Water and Sewer Department and Department of Regulatory and Economic Resources

Estimation of Capture Zones and Drawdown at the Northwest and West Well Fields, Miami-Dade County, Florida, Using an Unconstrained Monte Carlo Analysis: Recent (2004) and Proposed Conditions

Open-File Report 2013-1086 



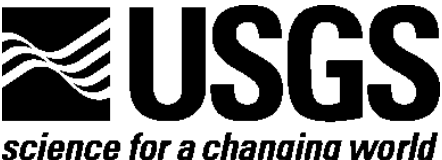

science for a changing world

Prepared in cooperation with the Miami-Dade County Water and Sewer Department and Department of Regulatory and Economic Resources

Estimation of Capture Zones and Drawdown at the Northwest and West Well Fields, Miami-Dade County, Florida, Using an Unconstrained Monte Carlo Analysis: Recent (2004) and Proposed Conditions

By Linzy Brakefield, Joseph D. Hughes, Christian D. Langevin, and Kevin Chartier

Open-File Report 2013-1086

U.S. Department of the Interior

U.S. Geological Survey 


\section{U.S. Department of the Interior KEN SALAZAR, Secretary}

\section{U.S. Geological Survey Suzette M. Kimball, Acting Director}

U.S. Geological Survey, Reston, Virginia: 2013

For more information on the USGS - the Federal source for science about the Earth, its natural and living resources, natural hazards, and the environment-visit http://www.usgs.gov or call 1-888-ASK-USGS

For an overview of USGS information products, including maps, imagery, and publications, visit http://www.usgs.gov/pubprod

To order this and other USGS information products, visit http://store.usgs.gov

Suggested citation:

Brakefield, L., Hughes, J.D., Langevin, C.D., and Chartier, K., 2013, Estimation of capture zones and drawdown at the Northwest and West Well Fields, Miami-Dade County, Florida, using an unconstrained Monte Carlo analysis: recent (2004) and proposed conditions: U.S. Geological Survey Open-File Report 2013-1086, 124 p.

Any use of trade, firm, or product names is for descriptive purposes only and does not imply endorsement by the U.S. Government.

Although this information product, for the most part, is in the public domain, it also may contain copyrighted materials as noted in the text. Permission to reproduce copyrighted items must be secured from the copyright owner. 


\section{Acknowledgments}

The authors would like to acknowledge assistance from Miami-Dade County Water and Sewer Department and the Department of Regulatory and Economic Resources employees Virginia Walsh, Maria MacFarland, Wilbur Mayorga and Rashid Istambouli for their assistance and support with data and review of the analyses and report. The authors would like to thank Dave Welter of the South Florida Water Management District for his insightful reviews, which led to improvement of the manuscript.

The authors would also like to acknowledge the helpful technical reviews of Kevin Cunningham and Jeffrey Starn of the U.S. Geological Survey, which greatly improved the clarity and thoroughness of the report. Conversations with Kevin Cunningham, in particular, greatly strengthened the Monte Carlo analysis presented in Appendix 1. Appreciation is also extended to Dorothy Payne, Robert Renken, Eve Kuniansky, Michael Deacon and Kim Swidarski for their editorial and technical reviews, which greatly improved the flow, organization, and clarity of the report. 



\section{Contents}

Acknowledgments..................................................................................................................................ii

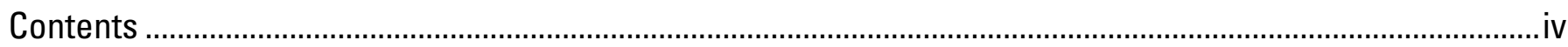

Abstract

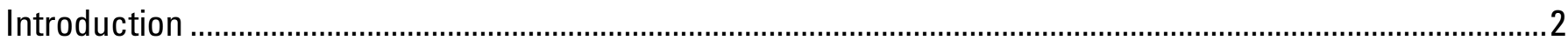

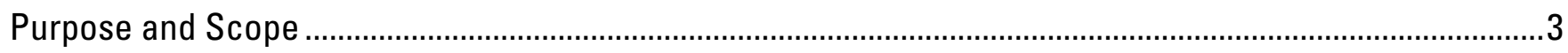

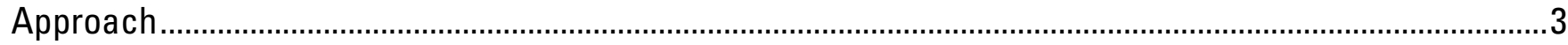

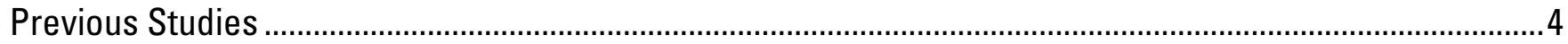

Description of Study Area .......................................................................................................................

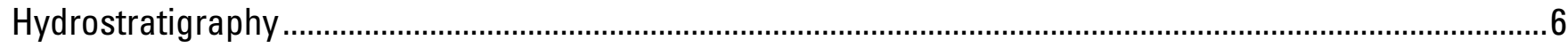

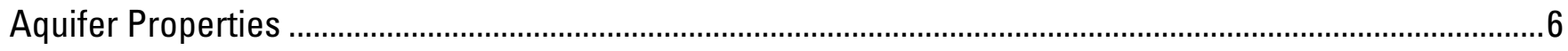

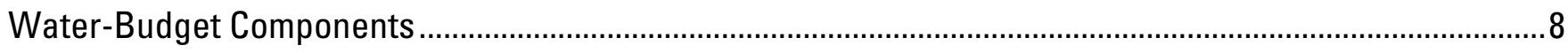

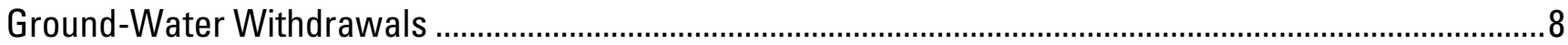

Surface-Water/Groundwater Interaction .............................................................................................

Rainfall, Evapotranspiration, and Runoff ...................................................................................

Simulation of Groundwater Flow near the Northwest and West Well Fields, 1996-2004 .................................10

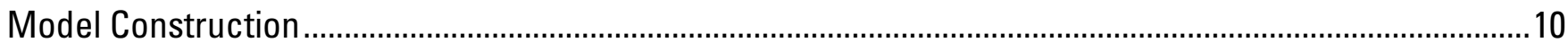

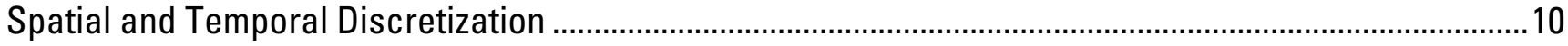

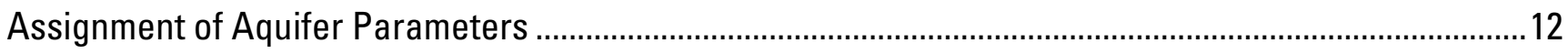

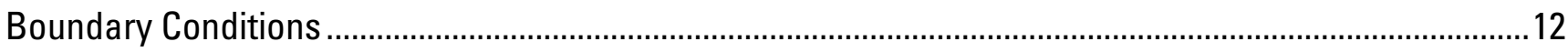

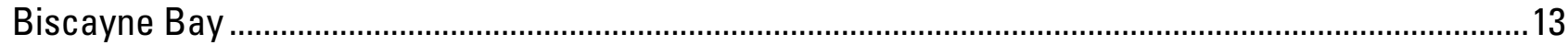

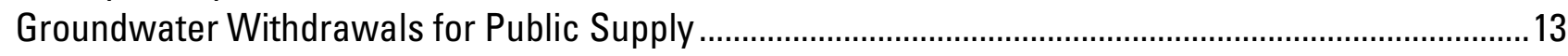

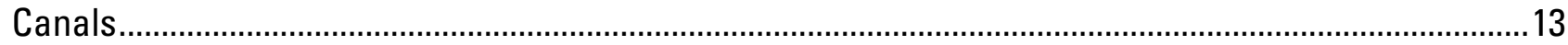

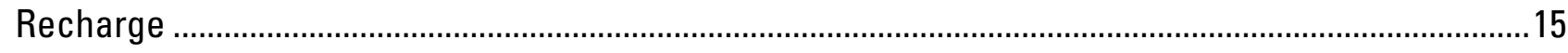

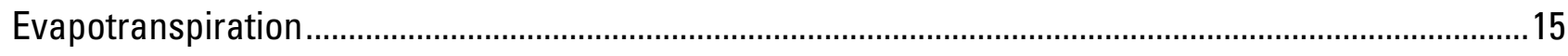

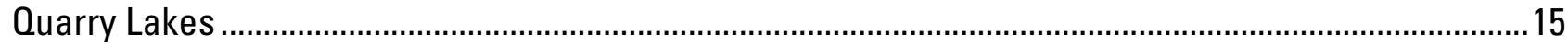

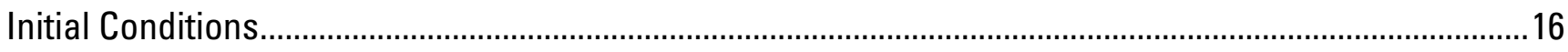

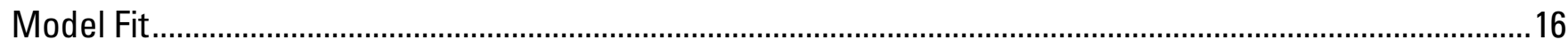

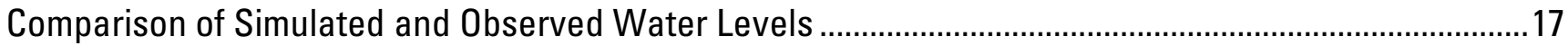

Comparison of Simulated and Observed Net Exchange between Canals and the Aquifer ........................18

Comparison of Dry and Wet Season Groundwater-Level Altitudes in Miami-Dade County.......................19

Estimation of Well-Field Capture Zones and Drawdown ............................................................................19

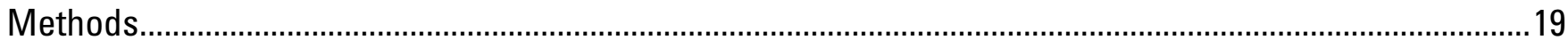

Lake Representation-Bulk Hydraulic Conductivity Calculation...............................................................20

Determination of Drawdown and Travel-Time Capture Zones.................................................................21

Evaluation of Uncertainty Using Monte Carlo Analysis ........................................................................22

Accounting for Uncertainty in Spatial Distribution of Hydraulic Conductivity ......................................22

Accounting for Uncertainty in Effective Porosity................................................................................24

Selection of Stress Period for Steady-State Particle-Tracking Simulation .............................................24

Simulated Time of Travel and Drawdown for Dry, Average, and Wet Hydrologic Conditions ........................25

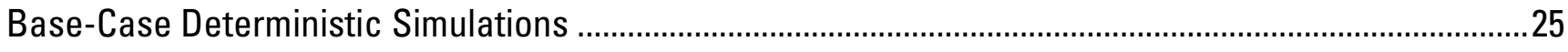

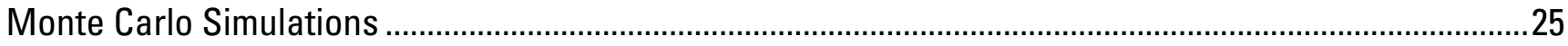


Two Proposed Scenarios: Potential Effects of Seepage Mitigation and Lake Expansion on Capture Zones and Drawdown

Proposed Scenario 1: Investigation of Effects of Seepage Mitigation .........................................................29

Proposed Scenario 2: Investigation of Effects of Lake Expansion .................................................................30

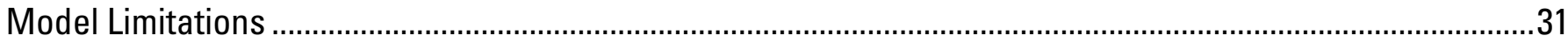

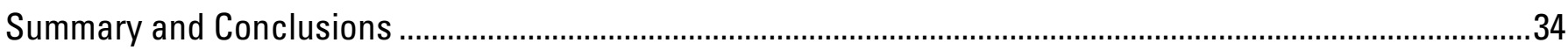

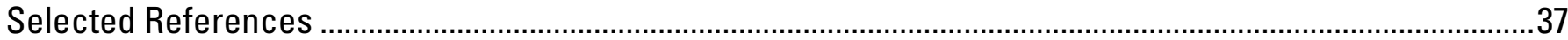

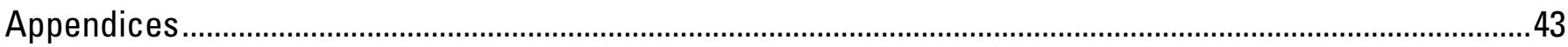

\section{Figures}

Figure 1. Locations of all base maps used throughout this report. Base maps are referred to in each map figure caption

Figure 2. Model grid extent, study area, hydrogeologic sections $A-A^{\prime}$ and $B-B^{\prime}$, location of production well fields and location of canals, southeastern Florida

Figure 3. Study area and existing Wellhead Protection Areas for production well fields in Miami-Dade County

Figure 4. Hydrogeologic cross section with subset section $A-A^{\prime}$

Figure 5. Hydrogeologic cross section $B-B^{\prime}$ across central part of the study area, including the Northwest Well Field

Figure 6. Altitude of the base of the Biscayne aquifer and its western extent throughout most of Miami-Dade County

Figure 7. Daily municipal supply well withdrawals from the Biscayne aquifer in Miami-Dade County for January 1, 1996, through December 31, 2004

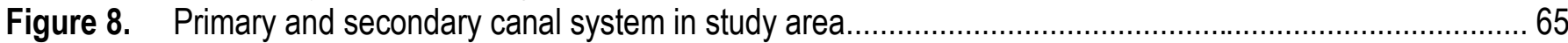

Figure 9. Location of active and inactive model cells, and type of MODFLOW boundary condition.........................66

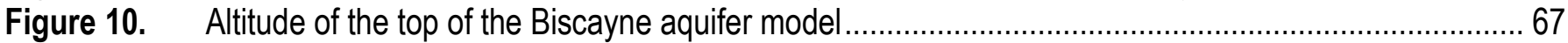

Figure 11. Hydraulic conductivity field for the base-case simulation and locations of transmissivity

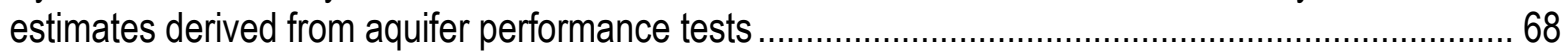

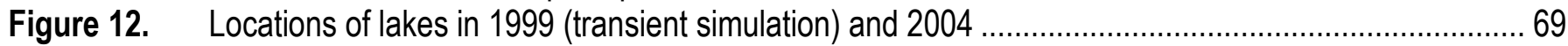

Figure 13. Daily observed and model-simulated water levels for selected monitoring wells in the study area...... 70

Figure 14. Locations of groundwater observation data used to calibrate model and mean error calculated from observed and simulated daily water levels .

Figure 15. Selected surface-water basins (shaded) in simulated area, locations of production wells, and canals

Figure 16. Monthly model-simulated and observed net exchange for composite C-4 and C-6 basins, and mean error, mean absolute error and the coefficients of determination for simulated versus

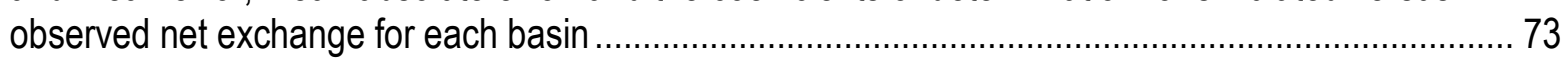

Figure 17. Average water-level differences for the Biscayne aquifer between May 1993 and May 1998 ............. 74

Figure 18. Average water-level differences for the Biscayne aquifer between November 1993 and

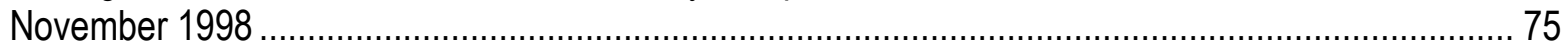

Figure 19. Hydraulic conductivity field used in transient and deterministic base-case steady-state simulations in the study area for the base-case simulation, and for three selected additional realizations 
Figure 20. Log-normal probability distribution of effective porosity used for sampling of random values for Monte Carlo analysis.

Figure 21. Tailwater stages at S-337 and G-119 with selected days representing dry, average, and wet hydrologic conditions identified with black circles

Figure 22. Simulated 0.25-foot and 0.1-foot drawdown contours, and particle endpoints for travel times of $10,30,100$, and 210 days for the base-case simulation of dry conditions.

Figure 23. Simulated 0.25 -foot and 0.1 -foot drawdown contours, and particle endpoints for travel times of $10,30,100$, and 210 days for the base-case simulation of average conditions

Figure 24. Simulated 0.25 -foot and 0.1 -foot drawdown contours, and particle endpoints for travel times of 10,30,100, and 210 days for the base-case simulation of wet conditions.

Figure 25. Simulated particle endpoint locations for travel times of 10, 30, 100, and 210 days for dry conditions for 10,000 realizations

Figure 26. Simulated particle endpoint locations for 210 days of travel for dry conditions for 100 realizations around the Northwest Well Field, and an example of the radial class division described by Varljen and Shafer.

Figure 27. Median and 95-percent confidence intervals for the 210-day capture zones for the Northwest Well Field and West Well Field for steady-state, dry conditions, and particle endpoints for 210 days of travel for the base-case simulation of dry conditions

Figure 28. Median and 95-percent confidence intervals for the 100-day capture zones for the Northwest Well Field and West Well Field for steady-state, dry conditions, and particle endpoints for 100 days of travel for the base-case simulation of dry conditions

Figure 29. Median and 95-percent confidence intervals for the 30-day capture zones for the Northwest Well Field and West Well Field for steady-state dry conditions, and particle endpoints for 30 days of travel for the base-case simulation of dry conditions

Figure 30. Median and 95-percent confidence intervals for the 10-day capture zones for the Northwest Well Field and West Well Field for steady-state, dry conditions, and particle endpoints for 10 days of travel for the base-case simulation of dry conditions

Figure 31. Median and 95-percent confidence intervals for the 210-day capture zones for the Northwest Well Field and West Well Field or steady-state, average conditions, and particle endpoints for 210 days of travel for the base-case simulation of average conditions.

Figure 32. Median and 95-percent confidence intervals for the 100-day capture zones for the Northwest Well Field and West Well Field for steady-state, average conditions, and particle endpoints for 100 days of travel for the base-case simulation of average conditions.

Figure 33. Median and 95-percent confidence intervals for the 30-day capture zones for the Northwest Well Field and West Well Field for steady-state, average conditions, and particle endpoints for 30 days of travel for the base-case simulation of average conditions

Figure 34. Median and 95-percent confidence intervals for the 10-day capture zones for the Northwest Well Field and West Well Field for steady-state, average conditions, and particle endpoints for 10 days of travel for the base-case simulation of average conditions.

Figure 35. Median and 95-percent confidence intervals for the 210-day capture zones for the Northwest Well Field (NWWF) and West Well Field (WWF) for steady-state, wet conditions, and particle endpoints for 210 days of travel for the base-case simulation of wet conditions 92

Figure 36. Median and 95-percent confidence intervals for the 100-day capture zones for the Northwest Well Field and West Well Field for steady-state, wet conditions, and particle endpoints for 100 days of travel for the base-case simulation of wet conditions

Figure 37. Median and 95-percent confidence intervals for the 30-day capture zones for the Northwest Well Field and West Well Field for steady-state, wet conditions, and particle endpoints for 30 days of travel for the base-case simulation of wet conditions. 
Figure 38. Median and 95-percent confidence intervals for the 10-day capture zones for the Northwest Well Field and West Well Field for steady-state, wet conditions, and particle endpoints for 10 days of travel for the base-case simulation of wet conditions.

Figure 39. Upper bounds of the 95-percent confidence intervals $(\mathrm{Cl})$ for the 210-day capture zones for the Northwest Well Field and West Well Field for steady-state, wet and dry conditions

Figure 40. Composite areal extent of the upper bounds of the 95-percent confidence intervals for the 210-day capture zones for the Northwest Well Field and West Well Field for steady-state, wet and dry conditions.

Figure 41. Median and 95-percent confidence intervals for 0.1-foot and 0.25-foot drawdowns for the Northwest Well Field and West Well Field for steady-state, dry conditions

Figure 42. Median and 95-percent confidence intervals for 0.1-foot and 0.25-foot drawdowns for the Northwest Well Field and West Well Field for steady-state, average conditions.

Figure 43. Median and 95-percent confidence intervals for 0.1-foot and 0.25-foot drawdowns for the Northwest Well Field and West Well Field for steady-state, wet conditions 100

Figure 44. Locations of the recharge canal west of the Northwest Well Field, the proposed slurry wall between the L-31N Levee and the L-31N Canal, and the Horizontal Flow Barriers west of the West Well Field for Scenario 1

Figure 45. Median and 95-percent confidence intervals for the 210-day capture zones for the Northwest Well Field for steady-state, dry conditions for seepage mitigation scenario and without seepage mitigation, and final particle endpoints for both conditions beyond 210 days 102

Figure 46. Upper bound of the 95-percent confidence intervals for the 210-day capture zones and upper bound of the 95-percent $\mathrm{Cl}$ for the 0.1-foot drawdown for the West Well Field for steady-state, dry conditions for seepage mitigation scenario and without seepage mitigation ......... 103

Figure 47. Upper bound of the 95-percent confidence intervals for the 100-day capture zones for the West Well Field (WWF) for steady-state, dry conditions for seepage mitigation scenario and without seepage mitigation....

Figure 48. Locations of existing lakes, projected expansion of existing lakes and new proposed lakes for lake-expansion scenario. 105

Figure 49. Median and upper bound of the 95-percent confidence intervals for the 210-day capture zones and upper bound of the 95-percent $\mathrm{Cl}$ for the 0.25 -foot drawdown for the Northwest Well Field for steady-state dry conditions for the lake expansion scenario and without lake expansion. 106

Figure 50. Upper bound of the 95-percent confidence intervals for the 210-day capture zones and upper bound of the 95-percent $\mathrm{Cl}$ for the 0.1-foot drawdown for the West Well Field for steady-state, dry conditions for the lake expansion scenario and without lake expansion

Figure 1-1. Simulated 500-day particle pathlines and head contours for one-layer conceptual Model A and three-layer conceptual model B.... 108

Figure 1-2. Model grid, locations of constant-head cells, river cells and pumping wells for Model A and Model B

Figure 1-3. Median and 95-percent confidence intervals for 1-foot drawdown for Model $A$ and Model B

Figure 1-4. Median and upper bound 95-percent confidence intervals for 210-day capture zones for Model A and Model B 
Figure 3-1. Simulated water levels for base-case, steady-state average conditions with model boundary as described in the main body of the report, with model boundary extended west of the western canals and general head boundary conductance of 269 square feet per day, and with model boundary extended west of the western canals and general head boundary conductance of $26,910 \mathrm{ft} / \mathrm{d}$

Figure 4-1. Simulated steady-state groundwater head and backward-tracked particle pathlines for the model representing lakes with high hydraulic conductivity and the model using the LAK Package to represent Lakes.

Figure 5-1. Daily observed and model-simulated water levels for monitoring wells in the study area not shown in figure 13.

Figure 6-1. Backward-tracked particle pathlines from a pumping well through lakes without residence-time post-processing and with residence-time post-processing

Figure 6-2. Map showing locations and numbering of lakes referred to in paper by Chin and others (2010)

\section{Tables}

Table 1. Monitoring well names, mean errors of head, mean absolute errors of head, and the coefficients of determination of simulated vs. observed values of head...

Table 2. Statistics of minimum value and maximum value of hydraulic conductivity for all realizations, prior to calculation of bulk hydraulic conductivities

Table 4-1. Simulated groundwater inflow, groundwater outflow, and evaporation lake water-budget terms for lakes simulated using the high-hydraulic-conductivity approach and the LAK Package .

Table 6-1. Residence times used in model documented in this report and those calculated by Chin and others (2010). 


\section{Conversion Factors, Abbreviations, and Datums}

\begin{tabular}{|c|c|c|}
\hline Multiply & By & To obtain \\
\hline \multicolumn{3}{|c|}{ Length } \\
\hline inch (in.) & 2.54 & centimeter $(\mathrm{cm})$ \\
\hline inch (in.) & 25.4 & millimeter $(\mathrm{mm})$ \\
\hline foot $(\mathrm{ft})$ & 0.3048 & meter $(\mathrm{m})$ \\
\hline mile (mi) & 1.609 & kilometer $(\mathrm{km})$ \\
\hline \multicolumn{3}{|c|}{ Area } \\
\hline square mile $\left(\mathrm{mi}^{2}\right)$ & 2.590 & square kilometer $\left(\mathrm{km}^{2}\right)$ \\
\hline \multicolumn{3}{|c|}{ Flow rate } \\
\hline foot per day (ft/d) & 0.3048 & meter per day $(\mathrm{m} / \mathrm{d})$ \\
\hline cubic foot per day $\left(\mathrm{ft}^{3} / \mathrm{d}\right)$ & 0.02832 & cubic meter per day $\left(\mathrm{m}^{3} / \mathrm{d}\right)$ \\
\hline million gallons per day (Mgal/d) & 0.04381 & cubic meter per second $\left(\mathrm{m}^{3} / \mathrm{s}\right)$ \\
\hline inch per year (in/yr) & 25.4 & millimeter per year $(\mathrm{mm} / \mathrm{yr})$ \\
\hline \multicolumn{3}{|c|}{ Rainfall rate } \\
\hline inch per day (in/d) & 0.0254 & meter per day $(\mathrm{m} / \mathrm{d})$ \\
\hline \multicolumn{3}{|c|}{ Hydraulic conductivity } \\
\hline foot per day (ft/d) & 0.3048 & meter per day $(\mathrm{m} / \mathrm{d})$ \\
\hline \multicolumn{3}{|c|}{ Transmissivity* } \\
\hline foot squared per day $\left(\mathrm{ft}^{2} / \mathrm{d}\right)$ & 0.09290 & meter squared per day $\left(\mathrm{m}^{2} / \mathrm{d}\right)$ \\
\hline \multicolumn{3}{|c|}{ Leakance } \\
\hline foot per day per foot $[(\mathrm{ft} / \mathrm{d}) / \mathrm{ft}]$ & 1 & meter per day per meter \\
\hline inch per year per foot $[(\mathrm{in} / \mathrm{yr}) / \mathrm{ft}]$ & 83.33 & $\begin{array}{l}\text { millimeter per year per meter } \\
{[(\mathrm{mm} / \mathrm{yr}) / \mathrm{m}]}\end{array}$ \\
\hline
\end{tabular}

\footnotetext{
APT Aquifer performance test

CDM Camp, Dresser \& McKee, Inc.

$\mathrm{Cl} \quad$ Confidence interval

ENP Everglades National Park

HFB Horizontal flow barrier package of MODFLOW

MAE Mean absolute error

ME Mean error

NWWF Northwest Well Field

RER Regulatory and Economic Resources (Miami-Dade County)

SGSIM Sequential Gaussian simulation method

SFWMD South Florida Water Management District

WHPA Wellhead protection area

WWF West Well Field
} 
Altitude is distance above the vertical datum.

Vertical coordinate information is referenced to the North American Vertical Datum of 1988 (NAVD 88) unless stated to be referenced to the National Geodetic Vertical Datum of 1929 (NGVD 29).

Horizontal coordinate information is referenced to the North American Datum of 1983 (NAD 83).

${ }^{*}$ Transmissivity: The standard unit for transmissivity is cubic foot per day per square foot times foot of aquifer thickness $\left[\left(\mathrm{ft}^{3} / \mathrm{d}\right) / \mathrm{ft}^{2}\right] \mathrm{ft}$. In this report, the mathematically reduced form, foot squared per day $\left(\mathrm{ft}^{2} / \mathrm{d}\right)$, is used for convenience. 


\title{
Estimation of Capture Zones and Drawdown at the Northwest and West Well Fields, Miami-Dade County, Florida, Using an Unconstrained Monte Carlo Analysis: Recent (2004) and Proposed Conditions
}

\author{
By Linzy Brakefield, Joseph D. Hughes, Christian D. Langevin, and Kevin Chartier
}

\begin{abstract}
Travel-time capture zones and drawdown for two production well fields, used for drinking-water supply in Miami-Dade County, southeastern Florida, were delineated by the U.S Geological Survey using an unconstrained Monte Carlo analysis. The well fields, designed to supply a combined total of approximately 250 million gallons of water per day, pump from the highly transmissive Biscayne aquifer in the urban corridor between the Everglades and Biscayne Bay. A transient groundwater flow model was developed and calibrated to field data to ensure an acceptable match between simulated and observed values for aquifer heads and net exchange of water between the aquifer and canals. Steadystate conditions were imposed on the transient model and a post-processing backward particle-tracking approach was implemented. Multiple stochastic realizations of horizontal hydraulic conductivity, conductance of canals, and effective porosity were simulated for steady-state conditions representative of dry, average and wet hydrologic conditions to calculate travel-time capture zones of potential source areas of the well fields. Quarry lakes, formed as a product of rock-mining activities, whose effects have previously not been considered in estimation of capture zones, were represented using high hydraulicconductivity, high-porosity cells, with the bulk hydraulic conductivity of each cell calculated based on estimates of aquifer hydraulic conductivity, lake depths and aquifer thicknesses. A post-processing adjustment, based on calculated residence times using lake outflows and known lake volumes, was utilized to adjust particle endpoints to account for an estimate of residence-time-based mixing of lakes. Drawdown contours of 0.1 and 0.25 foot were delineated for the dry, average, and wet hydrologic conditions as well. In addition, 95-percent confidence intervals (CIs) were calculated for the capture zones and drawdown contours to delineate a zone of uncertainty about the median estimates.

Results of the Monte Carlo simulations indicate particle travel distances at the Northwest Well Field (NWWF) and West Well Field (WWF) are greatest to the west, towards the Everglades. The manmade quarry lakes substantially affect particle travel distances. In general near the NWWF, the capture zones in areas with lakes were smaller in areal extent than capture zones in areas without lakes. It is possible that contamination could reach the well fields quickly, within 10 days in some cases, if it were introduced into lakes nearest to supply wells, with one of the lakes being only approximately 650 feet from the nearest supply well.
\end{abstract}


In addition to estimating drawdown and travel-time capture zones of 10, 30, 100, and 210 days for the NWWF and the WWF under more recent conditions, two proposed scenarios were evaluated with Monte Carlo simulations: the potential hydrologic effects of proposed Everglades groundwater seepage mitigation and quarry lake expansion. The seepage mitigation scenario included the addition of two proposed anthropogenic features to the model: (1) an impermeable horizontal flow barrier east of the L-31N canal along the western model boundary between the Everglades and the urban areas of Miami-Dade County, and (2) a recharge canal along the Dade-Broward Levee near the NWWF. Capture zones and drawdown for the WWF were substantially affected by the addition of the barrier, which eliminates flow from the western boundary into the active model domain, shifting the predominant capture zone source area from the west more to the north and south. The 95-percent CIs for the 210-day capture zone moved slightly in the NWWF as a result of the recharge canal. The lake-expansion scenario incorporated a proposed increase in the number and surface area of lakes by an additional 25 square miles. This scenario represents a150-percent increase from the 2004 lake surface area near both well fields, but with the majority of increase proposed near the NWWF. The lake-expansion scenario substantially decreased the extent of the 210-day capture zone of the NWWF, which is limited to the lakes nearest the well field under proposed conditions.

\section{Introduction}

The karstic Biscayne aquifer in Miami-Dade County has high permeability, is shallow and minimally confined, and thus, there are strong interactions between surface-water features and the aquifer, making the aquifer sensitive to activities at the surface. Regional groundwater flow across the aquifer beneath Miami-Dade County (fig. 1) is generally from the wetlands in the western part of the county toward Biscayne Bay to the southeast. Groundwater in the aquifer in the north-central part of the county flows predominantly through stratiform, high-permeability flow zones characterized by macroporosity features that provide pathways for rapid transport of groundwater, and result in some of the highest transmissivity values ever recorded. The county pumps approximately 400 million gallons per day (Mgal/d) from the aquifer, and it is a designated sole source of drinking water (Federal Register Notice, 1979). Some public supply well fields that pump from the Biscayne aquifer are in proximity to canals that were built to control inundation and aquifer recharge, and to quarry lakes, and there is concern about the risk that contamination of these surface-water features poses to the Biscayne aquifer. To better protect the groundwater supply, the U.S. Geological Survey, in cooperation with Miami-Dade County, initiated in 2008 a hydrologic investigation of the Biscayne aquifer to evaluate the interactions between groundwater and surface water.

Of particular concern for Miami-Dade County are the Northwest Well Field (NWWF) and West Well Field (WWF), located in the northwestern part of the urbanized part of the county (fig. 2). The NWWF is the largest supply well field for drinking water purposes in Miami-Dade County and is designed to withdraw $225 \mathrm{Mgal} / \mathrm{d}$ of water. The WWF is located southwest of the NWWF and has a capacity to withdraw $25 \mathrm{Mgal} / \mathrm{d}$. Both well fields are near canals, and the NWWF is near numerous quarry lakes. Several proposed construction projects may affect groundwater flow fields at and around the well fields. The county has established "Wellhead protection areas" (WHPAs) (fig. 3) around the well fields to limit activities that may adversely affect the productivity of the well fields and the groundwater quality. The county uses results of groundwater flow models, including estimated capture zones and drawdown, to establish the WHPAs. There is considerable uncertainty in these estimations, and quantification of the uncertainty may assist the county in protection of groundwater that supplies the well fields. Furthermore, evaluating the uncertainty in hydraulic properties, canal exchanges, and lake 
residence times may assist the county in understanding the risk to the groundwater supply from contamination of local surface and subsurface areas near these well fields.

\section{Purpose and Scope}

This report documents estimates of well-field capture zones and drawdown using a stochastic approach near the NWWF and WWF based on current understanding of the local hydrogeology and hydrology. To estimate well-field capture zones and drawdown, a groundwater model was constructed that allows for an evaluation of uncertainty in the results based on known uncertainties in the conceptualization of the flow system, groundwater exchanges with the canals and lakes, and hydraulic parameters. This report documents the development of the flow model for transient and steady-state conditions, including an unconstrained Monte Carlo analysis used with the steady-state simulations to estimate time-based capture zones and drawdown contours with 95-percent confidence intervals. The model was also used to investigate effects on capture zones and drawdown by proposed anthropogenic alterations to the hydrologic system. One scenario considers the effects of seepage mitigation, including a barrier to the groundwater flux from the west of the WWF, and implementation of a recharge canal west of the NWWF. A second scenario highlights potential effects from proposed lake expansion in the Lake Belt area.

\section{Approach}

Hydrologic analyses based on groundwater flow models have been used for delineating the areas that provide recharge to a supply well (Starn and Brown, 2007; Starn and others, 2000; Franke and others, 1998; Snyder and others, 1998; Barlow, 1995; Reilly and Pollock, 1993). Hydrologic analyses are often used to determine the impact of a municipal supply well on the surrounding aquifer and the spatial extent of this impact. One common method is to delineate travel-time capture zones. Capture zones provide insight into the lateral extent of the recharge area for a supply well, but because they are defined by specified times of travel, the zones may not necessarily encompass the entire contributing area for a given supply well. Additionally, drawdown, defined in this study as the difference in waterlevel altitude caused solely by well-field withdrawals, can be used to indicate how a well field will affect groundwater flow patterns. In this investigation, travel-time capture zones of 10, 30, 100, and 210 days were delineated, as well as 0.25 -foot (ft) and 0.1 -ft drawdown contours.

Groundwater models that provide estimates of capture zones and drawdown typically use a deterministic approach in which a single result is produced based from a single set of model input parameters. Uncertainty in simulated results cannot be quantified with this approach. The hydrologic analysis presented herein uses an unconstrained Monte Carlo analysis to delineate the 95-percent confidence interval (CI) associated with simulated capture zones and drawdown contours. With the Monte Carlo analysis, capture zone and drawdown contours are calculated for many different parameter sets that are equally plausible, in a statistical sense. Each parameter set and associated model result is called a realization. The approach is considered unconstrained in that no attempt was made to calibrate each realization. Reference to this approach is simply referred to as "Monte Carlo analysis" throughout the report, although in all instances the Monte Carlo simulations are unconstrained. Uncertainty in capture zones and drawdown can be assessed by evaluating the ensemble, which is the collection of all realizations. Monte Carlo methods have been used previously for these types of analyses (Varljen and Shafer, 1991; Bair and others, 1991; Franzetti and Guadagnini, 1996; Starn and others, 2000; Starn and Brown, 2007; Starn and others, 2010). 
The numerical groundwater flow model used for this study was calibrated for a 9-year simulation period, and then steady-state simulations of dry, average, and wet conditions were used along with the Monte Carlo analysis to estimate the median and 95-percent CI for both capture zones and drawdowns. Well-field withdrawal rates used in the steady-state simulations were based on updated design capacities provided by Miami-Dade County and differ from those used in previous analyses. The hydraulic effect of quarry lakes is a prominent component of the steady-state simulations presented herein. The unconstrained Monte Carlo analysis was also applied to proposed hydrologic scenarios in order to demonstrate how well-field capture zones and drawdown might be affected by possible alterations to the existing water management system in Miami-Dade County. The approach and methods discussed herein are also transferable to other studies that involve estimation of well-field capture zones and drawdown.

\section{Previous Studies}

The existing Wellhead Protection Areas (WHPAs) for the NWWF (fig. 3) were delineated using results from a one-layer groundwater model developed by Camp Dresser \& McKee Inc. (CDM). The CDM model was constructed using a modified version of the Prickett-Lonnquist Aquifer Simulation Model (PLASM) (Camp Dresser \& McKee, 1985; Prickett and Lonnquist, 1971). The PLASM code is similar to MODFLOW in that it is based on a finite-difference approximation of the groundwater flow equation. Lakes were not represented in the CDM model and the NWWF withdrawal rate was set at $220 \mathrm{Mgal} / \mathrm{d}$ (Camp Dresser \& McKee, 1985). The effects of lakes are included in the present analysis and the maximum design-capacity pumping rate for the NWWF is $225 \mathrm{Mgal} / \mathrm{d}$.

The existing WHPAs for the WWF (fig. 3), based on travel-time capture zones and drawdown delineated by a separate groundwater flow model than the model used for the NWWF, are based on the projected 1992 withdrawal rate of $140 \mathrm{Mgal} / \mathrm{d}$ (Department of Environmental Resources Management, 1992). Presently, the withdrawal rate for the WWF is only $25 \mathrm{Mgal} / \mathrm{d}$ from three wells in the southern part of the well field. Therefore, results from the numerical simulations described herein are not directly comparable to the existing capture zone and drawdown delineations of the WWF (fig. 3).

In 2001, CH2M Hill developed a MODFLOW model and used particle tracking to delineate capture zones of 180 and 230 days of travel to determine rock-mining setback distances for ongoing mining near the NWWF (CH2M Hill, 2001). The NWWF withdrawal rate used in the CH2M Hill model was $235 \mathrm{Mgal} / \mathrm{d}$. Effects of lakes on the capture zones were investigated with the model by representing the lakes as high-porosity and high hydraulic-conductivity zones having a depth of $70 \mathrm{ft}$ below land surface. The CH2M Hill model was based on the North Miami-Dade County Sub-Regional Groundwater Flow Model developed by the South Florida Water Management District (SFWMD). The CH2M Hill model contained multiple layers and incorporated more accurate, updated estimates of Biscayne aquifer transmissivities compared to those used in the $1985 \mathrm{CDM}$ model. The travel-time capture zones of the CH2MHill model results were more spatially extensive west of the NWWF because of the updated transmissivities, presence of lakes in the eastern part of the well field, and a greater wellfield withdrawal rate. Although the $\mathrm{CH} 2 \mathrm{M}$ Hill model provides a more updated assessment of groundwater flow and times of travel near the well field than offered by the $1985 \mathrm{CDM}$ model, the existing Miami-Dade WHPA maps are based on capture zone and drawdown results from the 1985 CDM model.

Since the determination of the existing WHPAs for the NWWF and WWF, more recent subsurface investigations in the area have characterized and mapped highly porous, stratiform, flow 
zones in the Biscayne aquifer that may play an important role in groundwater flow and contaminant transport in the study area (Cunningham and others, 2006a, 2009; Renken and others, 2005, 2008). These investigations focused primarily on the upper part of the Tamiami Formation, Fort Thompson Formation, and Miami Limestone. The purpose of these investigations was to characterize the lithologic variations, cyclostratigraphy, aquifer properties, and identify groundwater flow zones in the karstic limestone that composes the Biscayne aquifer. The increased potential for risk of contamination because of these flow zones near supply wells was investigated through the use of multiple tracer tests in 2003 and 2004 near the NWWF (Renken and others, 2005, 2008; Shapiro and others, 2008; Harvey and others, 2008). Results indicated that flow near the NWWF is dominated by megaporosity flow zones, and that the potential transport of contaminants could be more rapid near this well field than previously thought. Shoemaker and others (2008a) used a version of MODFLOW capable of accounting for turbulent groundwater flow (MODFLOW-Conduit Flow Process (CFP) - Shoemaker and others, 2008b) and a multi-layer model to investigate the potential for (1) turbulent flow in highly permeable flow zones of the Biscayne aquifer in the Lake Belt area and (2) the effects of turbulent flow on hydraulic heads and parameter sensitivities.

Guha (2008) developed a multi-layer model with stochastic MODPATH 5.0 particle tracking of the NWWF area to estimate a 60-day travel-time capture zone for WHPA refinement purposes. The Monte Carlo analysis used 300 spatially-constant realizations sampling a uniform distribution of hydraulic conductivity for an assumed occurrence of a single flow zone in the Biscayne aquifer. Lakes were modeled as high hydraulic conductivity cells using a hydraulic conductivity of $1.00 \times 10^{6}$ feet per day $(\mathrm{ft} / \mathrm{d})(305 \mathrm{~km} / \mathrm{d})$. Chin and others (2010) used an advective particle-tracking method with a random-walk dispersive component to estimate travel-time capture zones in locations containing lakes using a residence-time approach. This method was applied to Guha's (2008) model to estimate capture zones for 10, 30, 100, and 210 days of travel. This approach is compared to the approach utilized in the present investigation and discussed in this report.

\section{Description of Study Area}

The study area is in the north-central part of Miami-Dade County and includes the NWWF and WWF (fig. 2). Much of the study area consists of protected wetlands (in particular the Pennsuco Wetlands, fig. 3), borrow-pit rock mines, upland forests, and agricultural lands. The southeastern portion of the study area consists of residential and commercial areas. The study area lies just east of the protected wetlands of Everglades National Park (ENP) and Water Conservation Area 3B. The study area includes the western edge of the urbanized part of Miami-Dade County. The study area is used not only for limestone mining, but it also serves as an important source of drinking water supply, and as a development buffer area between the urban parts of the county and ENP and Water Conservation Area 3B. The study area is dominated by the 89-square-mile $\left(\mathrm{mi}^{2}\right)$ Lake Belt area (figs. 2 and 3), named for its characteristic presence of extensive quarry "lakes" formed through rock-mining activities. These man-made water bodies are the major open-water features in the study area and are referred to simply as lakes in the remainder of this report. 


\section{Hydrostratigraphy}

The focus of this investigation is the Biscayne aquifer, the primary source of municipal water supply for Miami-Dade County and a designated sole source of drinking water (Federal Register Notice, 1979) (figs. 4 and 5). The Biscayne aquifer is the highly permeable, uppermost part of the surficial aquifer system (Parker, 1951), which is composed of lithostratigraphic units of varying permeability from land surface downward to the top of the intermediate confining unit, at a depth between about 160 and $200 \mathrm{ft}$ below NGVD 29 (Fish and Stewart, 1991; Reese and Cunningham, 2000). In this investigation, the Biscayne aquifer is defined as that part of the surficial aquifer system composed of the modern peats, Miami Limestone, Fort Thompson Formation, and the Tamiami Formation where it is sufficiently permeable (based on borehole geophysical logs and flowmeter measurements published by Cunningham and others, 2004a, 2006b) (figs. 4 and 5). The Biscayne aquifer is underlain by a confining to semiconfining unit.

Parker (1951) indicated that the Biscayne aquifer is unconfined. Fish and Stewart (1991) clarified this by noting that over most of the area "(except near well fields or margins of waterconservation areas), water levels at depth are almost identical to local water-table elevations." Fish and Stewart (1991) observed that variations in the vertical distribution of water-level responses, during the early stages of pumping in wells open to highly permeable zones overlain by less permeable sands, may indicate semiconfined behavior. For well fields along the margins of water conservation areas, Fish and Stewart (1991) also noted that water levels measured at depth may differ from those observed at the water table. For example, near the Levee 30 Canal west of the NWWF, Sonenshein (2001) mapped vertical water-level differences on the order of $0.1 \mathrm{ft}$ or less.

In Miami-Dade County, the Biscayne aquifer is thickest at the coast and thins toward the west (fig. 4). In the study area, the base of the Biscayne aquifer generally dips eastward (fig. 6). The areal extent, bottom altitudes, and characteristics of the Biscayne aquifer are discussed at length in Fish and Stewart (1991). This highly transmissive aquifer, in the study area, comprises multiple vertical lithofacies successions (Cunningham and others, 2006a, b) arranged within high-frequency cycles (fig. 5). Vertical lithofacies successions record the prevailing water depth during a single cycle of relative rise and fall in sea level (Kerans and Tinker, 1997), and within the Biscayne aquifer in the study area, porosity and permeability are typically linked to the vertical arrangement of lithofacies within each succession that composes a high-frequency cycle (Cunningham and others, 2006a, b). In particular, megaporosity (also referred to as "touching vug porosity"), which is associated with highly permeable flow zones in the Biscayne aquifer, correlates with cyclostratigraphic sequences across the study area (fig. 5).

Highly porous, groundwater flow zones have been characterized and mapped throughout much of the study area and identified in other parts of the Biscayne aquifer in Miami-Dade County (Cunningham and others, 2004a, b, 2006a, b, 2009; Renken and others, 2005, 2008; Shapiro and others, 2008; Cunningham and Sukop, 2011). The cumulative thickness of the flow zones across the entire thickness of the aquifer at the NWWF is estimated to be about $29.5 \mathrm{ft}$ (9 m) (Renken and others, 2008).

\section{Aquifer Properties}

Transmissivity values for the Biscayne aquifer derived from aquifer performance tests (APTs) vary widely throughout Miami-Dade County. Fish and Stewart (1991) reported a range in transmissivity values for the surficial aquifer, which includes the Biscayne and gray limestone aquifers, of about 49 to $2.9 \times 10^{6}$ square feet per day $\left(\mathrm{ft}^{2} / \mathrm{d}\right)$; few of these estimates were made near the NWWF and WWF. 
Transmissivity values reported for the Biscayne aquifer, however, are generally higher than those reported for the gray limestone aquifer (Fish and Stewart, 1991; Reese and Cunningham, 2000). Results of an APT at the NWWF (Renken and others, 2008) yielded estimates of transmissivity ranging from $1.67 \times 10^{6} \mathrm{ft}^{2} / \mathrm{d}$ to $3.07 \times 10^{6} \mathrm{ft}^{2} / \mathrm{d}$. These data were acquired as part of a pathogen and chemical transport study to characterize and delineate flow through flow zones in the Biscayne aquifer near the NWWF. The flow zones constitute the main pathways of groundwater flow in the Lake Belt area (figs. 2 and 5) and therefore, are an important component of the hydrogeologic framework in regards to both groundwater flow and contaminant transport (Cunningham and others, 2006a, b; Renken and others, 2005, 2008; Shapiro and others, 2008). Delayed aquifer responses during these aquifer performance tests were attributed to the dual-porosity nature of the Biscayne aquifer. The flow was conceptualized as initial flow and storage depletion from high-porosity zones, and subsequent release of storage from less transmissive overlying and underlying units (Renken and others, 2005, 2008). These delayed aquifer responses are early-time phenomena and strongest near supply wells.

An important aquifer property controlling contaminant transport rates through an aquifer is effective porosity. Although aquifer bulk porosity is defined as the percentage of the total aquifer volume composed of voids, or rock pores, effective porosity is usually smaller because it only includes those voids that are interconnected; therefore, bulk porosity is always an upper bound to any estimates of effective porosity. Cunningham and others (2009) describe the karstic Biscayne aquifer as a dualporosity system consisting of (1) matrix porosity (characterized by interparticle and separated vugs), which provides groundwater storage, and (2) megaporosity (characterized by macroporous touching vugs), which creates stratiform, areally extensive, groundwater-flow pathways, and less common bedding-plane and cavernous vugs and thin vertical solution pipes. Reported values of bulk helium porosity measured in the study area range from 5.5 to 50.2 percent (Cunningham and others, 2004a, 2006b). Notably, a computer rendering of a megaporous outcrop limestone sample of the Biscayne aquifer from the Atlantic Coastal Ridge in Miami-Dade County has a megapore system dominated by burrow porosity calculated to be 78 percent (Cunningham and Sukop, 2011).

Estimates of effective porosity are commonly made from the mean arrival time of a tracer breakthrough curve. A field tracer test conducted at the NWWF using rhodamine water-tracing dye and deuterium oxide yielded effective porosity estimates ranging from 4 percent to 41 percent. The 4 percent value considers all megaporosity high-flow zones, which is considered to be the lower range for effective porosity in this area, whereas the 41 percent value considers transport solely through what was hypothesized to be the main flow zone at an altitude of $-31.5 \mathrm{ft}(-9.6 \mathrm{~m})$ (Renken and others, 2008). This approximation is based on the travel time of the peak breakthrough concentration, as the mean travel time could not be calculated for this test because it was prematurely terminated. Calibrated numerical models of the Biscayne aquifer in Miami-Dade County, which can also be used to estimate effective porosity, have incorporated values of 0.20 for effective porosity (Merritt, 1996, 1997; Langevin, 2001, Chin and others, 2010; Lohmann and others, 2012).

Estimates of hydraulic storage properties are needed to simulate transient responses. The Biscayne aquifer is generally unconfined, thus, specific yield, which is a measure of the ratio of the volume of water an aquifer will yield by gravity drainage to the volume of the aquifer, is the storage property required. Specific yield is commonly assigned a value between 0.20 and 0.25 based on (1) the quantification of aquifer responses to known rainfall events and (2) estimates from calibrated models (Merritt, 1996, 1997; Langevin, 2001, Lohmann and others, 2012). 


\section{Water-Budget Components}

The hydrology of southern Florida is characterized by distinct wet and dry seasons, high evapotranspiration rates, and surface-water management features designed to control aquifer heads. In general, the regional groundwater flow direction in the Biscayne aquifer is from west to east, with eventual discharge into Biscayne Bay. Groundwater withdrawals from the Biscayne aquifer are considerable, and therefore substantially affect the groundwater flow field. The high transmissivities of the Biscayne aquifer facilitate rapid responses of groundwater levels to changes in rainfall and managed canal stages.

\section{Ground-Water Withdrawals}

A principal hydrologic stress affecting flow through the groundwater system is well-field withdrawal. Groundwater is withdrawn from the NWWF and WWF for residential as well as commercial and industrial uses. The NWWF consists of 15 wells that have a maximum design-capacity pumping rate of $225 \mathrm{Mgal} / \mathrm{d}$, making it the largest well field used for drinking water supply in Florida. The WWF consists of three wells that have a maximum design-capacity pumping rate of $25 \mathrm{Mgal} / \mathrm{d}$. These design capacities are much larger than the actual and historical pumping rates. The actual volumetric daily pumping rates for the NWWF over the period of January 1996 to December 2004 ranged from 18.5 to $166 \mathrm{Mgal} / \mathrm{d}$ (V. Walsh, Miami-Dade Water and Sewer Department, unpub. data, 2008). Volumetric daily pumping rates for the WWF, between 1997 (when the well field became operational) and December 2004, ranged from 0 to $24.6 \mathrm{Mgal} / \mathrm{d}$ (V. Walsh, Miami-Dade Water and Sewer Department, unpub. data, 2008).

There are many other supply well fields withdrawing groundwater from the Biscayne aquifer in Miami-Dade County (fig. 2). Total municipal groundwater withdrawals in Miami-Dade County for the 1996-2004 period generally range from 350 to $440 \mathrm{Mgal} / \mathrm{d}$ (fig. 7). Groundwater withdrawals from the Biscayne aquifer for agricultural purposes are not accounted for in this investigation, but are estimated to be approximately 46.5 Mgal/d (Marella, 2009). Most agricultural groundwater withdrawals are made in the southern part of Miami-Dade County outside of the study area.

\section{Surface-Water/Groundwater Interaction}

The interconnected network of water-management features, including canals and control structures, is a unique aspect of the study area and southeastern Florida. These features have a strong influence on the hydrologic system. Water-management canals include primary canals, managed by the SFWMD, and secondary and tertiary canals maintained by the county or by local entities. Structures located along these canals are used to manage canal stages by controlling flow between canals. During the dry season, canal structure operations are designed to control water levels in the canals to maintain aquifer heads for water supply and to minimize saltwater intrusion near the coast. During the wet season, operations are designed mainly to provide flood control, whereby runoff from urban and agricultural areas collects in canals and is eventually discharged to Biscayne Bay. Flow within the canal network is generally from west to east, from primarily wetland areas through more urbanized parts of the county, with eventual discharge of surplus water to the ocean.

Groundwater in the Biscayne aquifer is closely coupled to the surface-water system because of the high transmissivity of the aquifer and its direct connection to the canals. Near the NWWF and WWF for example, the secondary Snapper Creek Extension Canal, (fig. 8), which extends from north to south 
directly east of the NWWF, is used to maintain heads in the aquifer during the dry season to prevent westward flow from urban contamination sources east of the canal. Thus, water levels in canals substantially influence the local aquifer heads and flow field. Canals can act as both a source of recharge to the aquifer (mostly in the dry season) and discharge (mostly in the wet season). In natural systems, baseflow refers to the portion of streamflow that is not runoff, that results from seepage of water from the aquifer into the stream. When groundwater levels fall below the stream stage, there can be losses of surface water into the aquifer. For purposes of this report, "net exchange" is defined as the gain or loss of water to the canal from the aquifer. Actual volumes or rates of recharge from canals and discharge to canals within a reach are difficult to quantify and are currently not well understood but are a large component of the water budget. Estimates of net exchange can be calculated using structure discharge data and are a surrogate for canal recharge and discharge to the aquifer.

\section{Rainfall, Evapotranspiration, and Runoff}

Aquifer recharge is typically the difference between rainfall and the sum of evapotranspiration and surface-water runoff. Rainfall is the largest source of water to the Biscayne aquifer in Miami-Dade County, with an estimated average of 53.5 inches per year (in/yr) during January 1, 1996, through December 31, 2004. This estimate is based on average annual precipitation data collected from rainfall stations throughout the county and downloaded from the SFWMD DBHYDRO environmental database. A substantial part of this rainfall, however, never directly recharges the aquifer because it is lost to (1) evaporation from ponded surface water (including lakes, canals, and wetlands), (2) plant transpiration, and (3) direct runoff to surface-water canals, some of which is eventually released into Biscayne Bay.

Evapotranspiration, defined as the loss of water to the atmosphere from evaporation and plant transpiration, is considerable in southeastern Florida. The average evapotranspiration rate was $40.4 \mathrm{in} / \mathrm{yr}$ during 1996 to 2004 for site 8 in German (2000), which is dry part of the year and not constantly wet or over open water (Lohmann and others, 2012). Based on this rate, a maximum of approximately 76 percent of the annual rainfall is lost through evapotranspiration.

Runoff refers to excess water flowing into surface-water bodies. Runoff occurs during highprecipitation events and depends on land-use type and soil moisture content. Precipitation falling on impervious surfaces present in highly urbanized areas becomes runoff that is routed to nearby drains, ditches, streams, or canals. Some portion of runoff into surface-water canals may eventually recharge the Biscayne aquifer; while the rest is discharged to Biscayne Bay. Precipitation falls primarily in wetland, wooded, or grassy undeveloped areas near the NWWF and WWF, which are located in the western, less urbanized part of Miami-Dade County. Precipitation not lost to evapotranspiration or that does not recharge the aquifer is routed to the C-4 and C-6 Canals (Cooper and Lane, 1987). Estimates of runoff in Miami-Dade County are difficult to quantify and therefore not available. Chin and Patterson (2005) found that the ratio of runoff to rainfall in the C-103/C-16 basin was in relatively close agreement with the percentage of impervious area. This correlation is likely a result of the high permeability of soils and underlying aquifer materials and observed limited runoff from pervious areas. Runoff is not accounted for in this investigation because the assumption is that direct runoff is minimal in the study area. This assumption is consistent with the findings of Chin and Patterson (2005). Impervious (urban) areas compose about 11 percent of the study area surrounding the NWWF and WWF, with most of the impervious area located in the southeastern part of the study area, outside the area directly affected by the NWWF and WWF. 


\section{Simulation of Groundwater Flow near the Northwest and West Well Fields, 1996-2004}

A two-dimensional, transient MODFLOW-2005 model (Harbaugh, 2005) was developed to simulate groundwater flow in the Biscayne aquifer of Miami-Dade County. The model was calibrated to observed groundwater levels and estimated net exchange during 1996-2004, and was shown to reasonably represent groundwater flow patterns in the area. The model was adjusted to represent steadystate dry, average and wet conditions, and used to estimate travel-time capture zones and drawdown contours for the NWWF and WWF. Backward particle-tracking simulations run using MODPATH 5.0 (Pollock, 1994), along with a lake residence-time post-processing adjustment, were used to develop travel-time capture zones; drawdown contours were calculated by subtracting water-level altitudes for simulations with and without groundwater withdrawals at the NWWF and WWF (and other major supply well fields nearby). Because of uncertainty in the hydraulic conductivity distribution, canal conductances, and representative values of effective porosity, the steady-state conditions were simulated using a stochastic approach, specifically, an unconstrained Monte Carlo analysis.

\section{Model Construction}

The model was constructed using MODFLOW-2005 (Harbaugh, 2005) to simulate the Biscayne aquifer flow system in Miami-Dade County for 1996-2004. The model accounts for daily canal-stage fluctuations; rainfall; evapotranspiration; water levels in Biscayne Bay, Card Sound, and Barnes Sound; and well-field withdrawals. The model was calibrated to observed historic Biscayne aquifer groundwater levels and net exchanges.

The model extends from Biscayne Bay, Card Sound, and Barnes Sound east and southeast of the study area to the L-31N and L-30 Canals in the western part of the study area (figs. 8 and 9). The northern model boundary is the C-9 Canal and the southern boundary is the C-111 Canal (fig. 9). These canals, as well as Biscayne Bay to the east and the L-30 and L-31N to the west, were chosen because they are hydraulic head boundaries and have daily observation data that can be used to specify the model boundary conditions. Stage and flow data for all of the canals making up the border of the active model domain can be used to specify best-estimates for head-dependent boundaries, or in the case of Biscayne Bay, time-varying specified-head conditions. While the Biscayne aquifer extends beyond these canals beneath wetlands to the west, the amount and variability of underflow is not known. Thus the area outside the northern, western, and southern head-dependent boundaries along the canals was not simulated and any exchange of water between these boundary canals and aquifer represents both underflow and canal exchange (fig. 9).

\section{Spatial and Temporal Discretization}

To simulate accurately groundwater heads, horizontal gradients, and flow near the NWWF and WWF, a uniform grid with a column and row width of $164 \mathrm{ft}(50 \mathrm{~m})$ was used throughout the model domain. This partitioning resulted in a model domain with 1,730 rows and 930 columns, yielding a total of 748,563 active model cells covering an approximate area of 1,550 $\mathrm{mi}^{2}$.

Multiple flow zones are known to exist in the Biscayne aquifer at some locations, but the aquifer was simulated using a single model layer for several reasons. Although the flow zones have been mapped over most of the study area, the connectivity of identified flow zones is unknown, they have not 
been mapped over the entire model domain, and there are only a few monitoring wells that measure water levels of specific flow zones. Furthermore, no APT data exist in the study area that provide vertical and horizontal hydraulic conductivity estimates of the individual flow zones, and no estimates exist of the spatial distribution of effective porosity. Simulation of the system using multiple layers to represent multiple flow zones would introduce substantial uncertainty into the analysis. A Monte Carlo analysis, which simulates the flow system thousands of times using thousands of possible realizations of the hydraulic properties, incorporates the uncertainty into simulated well-field capture zones and drawdown patterns. Furthermore, for the analysis to be tractable with available computational resources, a single realization had to run in less than a minute, and simplification of a one layer model helped control simulation run times. Simulations of groundwater flow in unconfined aquifers are often represented in two dimensions, instead of three, if the Dupuit assumptions hold (Anderson and Woessner, 1992). The Dupuit assumptions are that the hydraulic gradient is equal to the slope of the water table and that equipotentials are vertical. No aquifer can precisely meet these assumptions, but in most areas and for most times, the Dupuit assumptions are satisfied in the Biscayne aquifer. For these reasons, the model uses a single-layer to simulate two-dimensional groundwater flow in the Biscayne aquifer.

Test simulations were conducted to evaluate the differences between simulating the aquifer using one or multiple layers (Appendix 1). An analysis was designed to identify any differences between the simulated hydraulic responses and travel times of a three-layer model with explicit parameters and a one-layer model with bulk hydraulic properties. This analysis demonstrated that estimates of travel-time capture zones and drawdowns from the one-layer model were slightly more spatially extensive than those same results from the three-layer model, but that the results were generally similar. Results from this investigation are consistent with Sepulveda and Kuniansky (2010) that demonstrated flow in the unconfined surficial aquifer system in Florida could be simulated reasonably well as a one-layer unit with calculated composite horizontal hydraulic conductivity based on a thickness-weighted, arithmetic mean of hydraulic conductivity values of multiple lithologic units.

The top of the model was set at land surface obtained from two different topographic datasets: a topographic contour land-surface map provided by ENP and a topographic map from NOAA (NGDC) Coastal Relief Model data (http://www.ngdc.noaa.gov/mgg/bathymetry/relief.html, June 2006). These datasets were combined and the centroid of each model grid cell was used to sample this coverage to determine the upper altitudes for each cell. The data and interpolations used for the land-surface altitudes are the same as those used in the Biscayne model developed by Lohmann and others (2012). Interpolated land-surface altitudes along the Biscayne Bay shoreline were set to a $0.0 \mathrm{ft}$ altitude to reflect NAVD 88 (fig. 10). Bottom cell altitudes were assigned using a map of the base of the Biscayne aquifer (Fish and Stewart, 1991, p. 41; fig. 6). Fish and Stewart (1991) developed their map and cross sections of hydraulic conductivity using an integrated dataset of lithologic sample and core descriptions, APT results, and drilling flow rates throughout Miami-Dade County.

Most temporal data used for model input or calibration were measured on a daily basis, with the exception of evapotranspiration rates, which were averaged from data collected at 15-minute intervals. One-day stress periods were used for the January 1996 - December 2004 period, yielding 3,288 MODFLOW stress periods. 


\section{Assignment of Aquifer Parameters}

The horizontal hydraulic conductivity field was created using APT data and spatial interpolation between test locations using ordinary kriging. A raw variogram, which mathematically describes spatial continuity, was calculated using an exponential variogram model with a correlation length of $16,404 \mathrm{ft}$ $(5,000 \mathrm{~m})$ and a sill, or asymptotic value of variance, of 0.3 of the log-transformed hydraulic conductivity values. Hydraulic conductivities were calculated by dividing measured transmissivity by the full thickness of the Biscayne aquifer at that location. The locations of transmissivity estimates from APTs in Miami-Dade County (Fish and Stewart, 1991; Renken and others, 2008) and the interpolated horizontal hydraulic conductivity field, which will be referred to hereafter as the "base-case" hydraulic conductivity field, are shown in figure 11. This base-case field was utilized in the transient model as well as in the deterministic steady-state model simulations. These deterministic steady-state simulations are referred to as the "base-case" simulations.

The Biscayne aquifer was simulated as a convertible MODFLOW layer, for which unconfined flow conditions are assumed when the head is below the top of the model cell and confined conditions are assumed when the head exceeds the top of a model cell. For this one-layer Biscayne aquifer model, a specific storage coefficient of $1.0 \mathrm{ft}^{-1}$ was assigned for the confined case in MODFLOW, such that when water levels rise above the top of the aquifer (land surface) a unit head change results in a unit change in storage volume per unit area. This means that the volume above land surface is 100 percent water by volume. The storage term for unconfined aquifers is known as specific yield, which is a measure of the volume of water stored or released from an aquifer under gravity-drainage of the pore space per unit surface area of aquifer per unit decline in head. Specific yield was set to 0.20 , based on previous calibrated models of this area by Langevin (2001) and Merritt $(1996,1997)$.

For the deterministic base-case simulations, effective porosity was set to 0.12 based on the average of effective porosity estimates from tracer tests (4 percent) and effective porosity values used in calibrated models of the area (20 percent) (Langevin, 2001; Merritt, 1996, 1997, Lohmann and others, 2012). This effective porosity value is within the range of bulk porosity estimates from Cunningham and others (2004a, 2006b) and estimates for the NWWF from Renken and others (2008). The value of 0.12 is also the same as the mean value for effective porosity of groundwater flow zone layers used in the Lake Belt area by Shoemaker and others (2008a).

\section{Boundary Conditions}

Flows into and out of the model were simulated using specified-head, specified-flux, or headdependent-flux boundary conditions in MODFLOW. Flow in the unsaturated zone was not represented in this model because (1) the volume of water in the unsaturated zone is small relative to the total volume of water in the Biscayne aquifer, and (2) based on analysis of rainfall data and groundwater response time, the delay between infiltration of rainfall and groundwater recharge is thought to be less than a day. A no-flow boundary condition was assigned to the model base as there is a low-permeability confining unit that limits leakage between the two aquifers (Fish and Stewart, 1991). Additonally, any leakage between the Biscayne aquifer and the underlying portion of the surficial aquifer is considered to be small relative to other water budget sources and sinks, such as evapotranspiration and rainfall, and therefore could be neglected. 


\section{Biscayne Bay}

The cells representing Biscayne Bay, Barnes Sound, and Card Sound are adjacent to actively simulated onshore cells and are simulated as prescribed-head boundaries using the time-varying specified head or "Constant-Head (CHD) Package" in MODFLOW-2005. Water levels in these cells were assigned using daily tailwater stage data from control structure S-123. This structure, located along the coast, is centered along Biscayne Bay in the model and has been used previously as a proxy for water levels in Biscayne Bay (Langevin, 2001). Although Biscayne Bay is saline and density variations can affect groundwater flow patterns near the coast, variable density effects were not taken into account in the model. It is reasonable to expect that coastal density variations would not affect model results in the NWWF and WWF areas because they are far from the coast and separated from it by the salinity control structures and other hydrologic stresses included in the model. Model cells in Biscayne Bay not adjacent to active onshore cells were inactivated and set as no-flow cells.

\section{Groundwater Withdrawals for Public Supply}

All supply well fields in Miami-Dade County were simulated using the MODFLOW-2005 well (WEL) Package. Pumping rates were based on measured, daily volumetric pumping rates, where available. In some cases, only monthly volumetric totals were available; therefore, daily groundwater withdrawal rates were distributed over the number of days in the month and per well. When only hourly withdrawal rates were available, hourly rates were averaged for each 24 -hour period. All well-field withdrawal data were provided by the Miami-Dade County Water and Sewer Department. The dataset is the same as that used for the 1996 to 2004 time period of Lohmann and others (2012) and withdrawals are estimated in the same manner as discussed in that report.

\section{Canals}

Canals were simulated as head-dependent fluxes using the River (RIV) Package in MODFLOW2005. The RIV Package requires canal stage levels for each stress period, the river-bottom altitude and a conductance value for each canal cell. Daily headwater and tailwater stages for primary canal structures were obtained from the SFWMD DBHYDRO database and used to define river stages for the RIV Package. Stage data collected for important secondary canals were also included in the model. The most important secondary canal included in the model was the Snapper Creek Extension Canal (fig. 8), which is used to maintain high heads in the aquifer during dry periods to prevent east to west flow and has a substantial effect on the heads and drawdown in the NWWF area. If stage data were not available for included secondary and tertiary canals, stage data from primary canals hydraulically connected to these canals were used or modified during calibration.

Other variables required by the RIV Package were taken directly, or calculated, from a spatial dataset provided by the SFWMD (Giddings and others, 2006). The canal conductance value (CRIV) required in the RIV Package was calculated using the following equation:

$$
C R I V=\frac{K \times L \times W}{M}
$$

where

$K \quad$ is the horizontal hydraulic conductivity of the cell, in feet per day; 
$L \quad$ is the length of the canal reach in the cell, in feet;

$W \quad$ is the width of the canal in the cell, in feet; and

$M \quad$ is the flow length, in feet.

The length of each canal attributed to each model cell was determined by superimposing a spatial representation of the canal on the model grid. The RIV Package was created by geospatially intersecting the GIS canal coverage with the model grid to calculate the length $(L)$ of each canal-reach polyline in each model cell. The width $(W)$ used in CRIV calculations for each RIV cell was calculated using the average of the top and bottom widths in the GIS coverage. Unlike other canal parameters, which can be directly measured or estimated, the flow length parameter $(M)$ is not explicitly defined by the RIV Package. The parameter is similar in magnitude to the grid-cell size and, as Swain and others (1996) state, "in purely mathematical terms," it is an estimate of the distance between the center of a canal (in cross section) and the point in the aquifer where the head in the aquifer is equal to the average head in the model cell. Therefore, the calculation of conductance in this investigation comes from the MODFLOW definition presented for equation 1 (McDonald and Harbaugh, 1988), but is slightly adjusted such that the flow length parameter is equivalent to the thickness of the river bed $b^{\prime}$ in Swain and others (1996, eq. A1). Although this calculation is based on a vertical-flow relation, it is assumed that most water exchange between the canals and the surrounding aquifer occurs along the canal walls where sedimentation would be less than that along the canal bottom. Sedimentation was not explicitly incorporated in the calculation of CRIV but is assumed to be included into the flow-length parameter. The assumption of flow occurring along the walls of the canal implies that the channel side dimension would be more important to use in the calculation of CRIV than the canal width. It is assumed, however, that the conductance value - and seepage as well — are proportional to the width of the canal. Therefore, the estimated canal width (the average of the top and bottom width) is used for $W$ in the CRIV calculation, and the adjustment of this value to actually account for wall seepage instead of canalbottom seepage is assumed to be accounted for in the adjustment of the flow length parameter $M$. An $M$ value of $32.8 \mathrm{ft}(10 \mathrm{~m})$ was used in the model, based on the 164- $\mathrm{ft}(50 \mathrm{~m})$ cell dimensions, and results from the model were not shown to be very sensitive to this parameter. MODFLOW-2005 was modified to calculate canal conductance internally from the horizontal hydraulic conductivity $(K)$ of the cell and the assigned conductance value of each RIV cell (Appendix 2), which was specified in the RIV Package and is equal to $L \times W / M$. Canal-bottom altitudes, which are required in the RIV Package, were also taken from an attribute in the Lower East Coast Sub-Regional MODFLOW (LECsR) model coverage.

The western extent of the active model boundary is located at the L-30 and the L-31N Canals. A head-dependent flux is applied at this boundary, using the RIV package. The boundary flux is controlled by the specified canal stage and the conductance of the RIV cells. This boundary condition controls all flow of water coming into the model from the west. In effect, this boundary condition simulates a composite flux of water recharging the aquifer from the canals, and flowing beneath the canals from the west. This boundary condition is similar to that used for the western model boundary in the investigation of Lohmann and others (2012). The model in Lohmann and others (2012) was a multiplelayer model, and a head-dependent flux boundary condition was applied to the layers beneath the canal. The top layer of the model of Lohmann and others (2012) actively simulated the surface-water network in this area, and exchange between the canal and the underlying aquifer. The approach used for the onelayer model documented in this report does not allow the flux from canal recharge to be distinguished from flux beneath the canal from the west. Furthermore, it does not allow a determination of the entire 
contributing area for each well field, because particles can only track backward into the canal, and cannot track into possible source areas in the inactive area west of the canal. Although some estimates exist for canal underflow (Sonenshein, 2001), the magnitude and variability of the flux of water from the west under the L-30 and L-31N canals is poorly understood. This boundary condition brings water into the actively simulated area to meet calibration targets, without quantifying canal underflow from areas west of the model edge. Testing of this boundary by actively simulating an area directly west of the NWWF indicated that water levels in the NWWF are not affected by adjusting the model boundary, thus extending the model area would not affect drawdown in the well field (Appendix 3).

\section{Recharge}

Recharge in the model was simulated as a specified flux using the Recharge ( $\mathrm{RCH})$ Package. No attempt was made to reduce rainfall rates by estimated runoff rates. Daily measured rainfall rates at 48 stations in Miami-Dade County were averaged over the 1996-2004 period to determine the spatial distribution of rainfall fluxes (in inches per day). The average daily rainfall from 1996 to 2004 at each of the 48 sites was plotted and contoured. The contour plot indicated that rainfall could be classified into (1) an area of high rainfall of $65.0 \mathrm{in} / \mathrm{yr}$ in the northern half of the model domain, and (2) an area of low rainfall of $48.8 \mathrm{in} / \mathrm{yr}$ in the southern half of the model. Because the NWWF and WWF lies in the northern portion of the model, daily rates from 11 rainfall stations located near the NWWF and WWF within the northern rainfall zone were averaged (66.5 in/yr) and applied uniformly throughout the entire model domain.

\section{Evapotranspiration}

Evapotranspiration was modeled as a head-dependent flux using the Evapotranspiration (EVT) Package. Physical parameters required by the EVT Package include an evapotranspiration surface (SURF); the extinction depth, which corresponds to the depth below SURF where evapotranspiration no longer occurs; and maximum evapotranspiration rates. Physically, the extinction depth generally corresponds to the root depth of vegetation, which is a function of land use and land coverage. SURF was defined to be land-surface altitude (fig. 10), and the extinction depth was defined to be $3.28 \mathrm{ft}(1 \mathrm{~m})$ below SURF. Langevin (2001) used extinction depths ranging from $0.49 \mathrm{ft}(0.15 \mathrm{~m})$ for barren land to $2.3 \mathrm{ft}(0.70 \mathrm{~m})$ for upland forests.

Daily average maximum evapotranspiration rates used in the EVT Package were calculated and processed from 15-minute time-series data collected at site 8 in German (2000) for initial use in the model of Lohmann and others (2012) for the same model domain. Open-water stations located in the Everglades and Water Conservation Areas (WCAs) 1, 2, and 3 were not used in this calculation of daily average maximum evapotranspiration rates, as these rates at open-water stations are generally higher than those at stations with vegetation. Site 8 is dry part of the year as opposed to other sites listed in German (2000), which are over open water or consistently wet.

Quarry Lakes

In the NWWF and WWF area, rock-mining activities have created large man-made quarry lakes that form as groundwater seeps into newly excavated areas. Near the NWWF, lakes are as close as $650 \mathrm{ft}$ from the nearest supply well. These quarry lakes are estimated to reach depths of 50 to $80 \mathrm{ft}$ into the Biscayne aquifer, which in some cases, is as deep as or deeper than the level of the production zone 
of the public-supply wells, indicating the potential for direct hydraulic connection between the lakes and the production zone.

Lakes were simulated using high hydraulic conductivity cells. Each cell whose centroid was within a lake was assigned a horizontal hydraulic conductivity of 328,084 ft/d $(100,000 \mathrm{~m} / \mathrm{d})$. As another option, the MODFLOW Lake (LAK) Package could have been used to simulate the lakes. An analysis was undertaken to ensure that the high hydraulic conductivity approach was comparable to explicit representation of lakes using the LAK Package (Appendix 4). This analysis indicates that the use of high hydraulic conductivity zones to represent lakes produces similar results compared to those obtained using the LAK Package.

To assign lake cells, a 1999 aerial photograph was used to determine the outlines of the lakes during the timeframe of the transient model (fig. 12). These outlines were overlain on the model grid, and cells that had their centroid within a lake were assigned as lake cells. Lake depths were not estimated for the transient model, although lake depths are estimated and taken into account for the steady-state scenario models, as discussed later. Groundwater levels in the study area tend to be higher than a $0.0 \mathrm{ft}$ altitude (Appendix 5, fig. 13) and lake water levels were assumed to be similar to or lower than surrounding aquifer heads. Therefore, for lake cells, the top altitude and SURF parameter in the EVT Package were assigned a value of $0.0 \mathrm{ft}$ altitude. This approach ensured that water would be removed at the maximum evapotranspiration rate from lake cells. Lakes are 100 percent water by volume, thus the storage property and effective porosity were both set to 1.0 at all lake cells.

The 1999 lake shapefile was used to define lakes in the transient model because lake images were collected near the middle of the 1996-2004 simulation period. The steady-state scenario model runs utilized a newer lake shapefile developed from 2004 aerial photography (fig. 12), in order to simulate more recent conditions.

\section{Initial Conditions}

Initial heads everywhere were assigned a value of $3.28 \mathrm{ft}(1 \mathrm{~m})$. Some initial errors are evident when comparing the observed water levels at monitoring wells to simulated heads, but these errors tend to dissipate quickly (within days) and have no effect on the steady-state particle tracking and drawdown results, which are the results of interest in this investigation.

\section{Model Fit}

Model calibration targets for this investigation included daily groundwater levels at 25 monitoring wells in the study area and monthly net exchange for two surface-water basins in the study area. The model was calibrated by manual adjustment of evapotranspiration extinction depth, canal conductance flow length, secondary and tertiary canal stage (those without stage data), and hydraulic conductivity to qualitatively match observed groundwater levels and net exchange and to represent generally observed features of the flow system. A qualitatively higher standard of model fit was required within the study area compared to the surrounding area. Thus, in areas outside of the influence of withdrawals at the NWWF and WWF, the model was only required to capture general hydrologic trends of the Biscayne aquifer.

Model calibration is typically required to yield realistic simulation results from a deterministic model, and thus the model was calibrated for transient conditions. The boundary conditions were modified to represent steady-state conditions to estimate the well-field capture zones and drawdown. Calibration to transient conditions ensures that the calibrated hydraulic parameters and model 
construction reasonably represent the hydrologic system, whereas the steady-state simulations yielded long-term hydrologic responses to input stresses that occur during the period of interest.

\section{Comparison of Simulated and Observed Water Levels}

Daily simulated and observed water levels were evaluated in 25 monitoring wells (fig. 14). These monitoring wells were selected based on their location relative to the area of interest and the availability of daily data for the transient simulation period. The water-level comparisons (fig. 13 and Appendix 5) show that, compared to historical observations, simulated water levels near the NWWF and WWF have similar seasonal fluctuation patterns and, in many cases, similar maxima and minima. Locations of groundwater observation data used to calibrate model and mean error calculated from observed and simulated daily water levels. Area shown is Base map 2 (fig. 1). NWWF is Northwest Well Field. WWF is West Well Field.

Three statistics used to describe the model fit are mean error (ME), mean absolute error (MAE) and the coefficient of determination, $\mathrm{R}^{2}$. The $\mathrm{ME}$, or average difference between daily observed and simulated values, is an overall indicator of how well a model simulates observed conditions at a specific location. It should not be considered as the only indicator, however, because a small ME value does not necessarily indicate a good model fit (Anderson and Woessner, 1992). The ME is a standard indication of any model bias present at a location. The MAE, a good statistical indicator of the average quantitative misfit at a location, is calculated by taking the average of the absolute values of the differences between daily observed and simulated water levels at each monitoring well. The $\mathrm{R}^{2}$, or coefficient of determination, is a statistical approximation of the relative variance of the misfit. $\mathrm{R}^{2}$ is calculated as follows:

$$
R^{2}=1-\frac{\sum_{i=1}^{n}\left(h_{i_{o b s}}-h_{i_{s i m}}\right)^{2}}{\sum_{i=1}^{n}\left(h_{i_{o b s}}-\bar{h}_{o b s}\right)^{2}}
$$

where

$$
\begin{array}{cl}
h_{i_{o b s}} & \text { is an observed water level at location } i ; \\
h_{i_{\text {sim }}} & \text { is a simulated water level at location } i ; \\
\bar{h}_{\text {obs }} & \text { is the mean observed water level; and } \\
n & \text { is the total number of observations. }
\end{array}
$$

The closer $\mathrm{R}^{2}$ is to unity, the better the fit is assumed to be. These statistics were calculated for all observations at each monitoring site and averaged for all wells to obtain a general value for the study area.

Observed groundwater levels for all wells for the simulated period ranged from -5.08 to $8.038 \mathrm{ft}$. The ME values for individual wells ranged from -0.653 to $2.139 \mathrm{ft}$, with an average of $0.009 \mathrm{ft}$ (fig. 14 and table 1), which indicates simulated values are generally lower than observed values. The MAE for individual wells ranged from 0.087 to $2.186 \mathrm{ft}$ (table 1), with an average MAE of $0.52 \mathrm{ft}$. The average 
MAE of $0.52 \mathrm{ft}$ is approximately 4 percent of the overall range of observed values (highest observed head minus lowest observed head, in feet) and approximately 9 percent of the average observed range at each of the 25 individual wells. $\mathrm{R}^{2}$ values ranged from 0.324 to 0.967 , with an average value of 0.753 . The largest ME and MAE generally occurred at monitoring wells located near supply wells (G-551, G-3253 and G-3259A) (fig. 14). It can be difficult to match simulated and observed heads near pumping wells because of transient well effects and model grid resolution. Furthermore, errors introduced in cases where volumetric well-field pumping totals or rates were converted to individual well rates using maximum pumping rates may have introduced additional error. A combination of these types of measurement error could have possibly resulted in overestimated or underestimated simulated heads at individual monitoring wells. $\mathrm{R}^{2}$ values at these three wells and at G-973 (just east of the study area) were also low (table 1, fig. 13, fig. 14, and Appendix 5).

Another useful statistic for determining model fit is the standard deviation of observed minus simulated groundwater heads, normalized to the range in observed heads (Kuniansky and others, 2004). A target value of 0.1 or less is preferred in order to indicate a good fit to the observed head data. The standard deviation of the observed minus simulated heads for all 78,443 values was 0.758 ; when divided by $13.12 \mathrm{ft}$ (the range in observed values), this yields 0.058 , which is below the target of 0.1 .

Sensitivity analyses of the model indicated that simulated heads are relatively insensitive to changes in hydraulic conductivity because of the high transmissivity of the Biscayne aquifer. Moreover, sensitivity analyses indicated observed heads can be matched relatively well even with changes to various model input parameters. This finding indicates that history-matching to groundwater heads at monitoring wells in the Biscayne aquifer, by itself, does not necessarily ensure the model is an accurate predictor of actual groundwater flow patterns.

\section{Comparison of Simulated and Observed Net Exchange between Canals and the Aquifer}

Sensitivity analyses indicated that the hydrologic system is strongly controlled by canal stage. High hydraulic conductivities in the model allow observed heads to be matched with relative ease, so the model was calibrated also to estimated monthly net exchange. Estimated net exchange observations, or net recharge or discharge rates for the primary canals within a basin, were calculated using the C-2, C-3, C-4, C-5, and C-6 surface-water basins delineated by Cooper and Lane (1987; fig. 15). Net exchange for the C-2, C-3, C-4, and C-5 basins (labeled with asterisks in figure 15) were grouped into a single basin because flow measurements were not available between the inflow structure for the C-4 basin at the western edge of the urban areas and the outflow structures for the C-2, C-3, C-4, and C-5 basins. Thus, the composite net exchange for the C-2, C-3, C-4, and C-5 basins is henceforth called C-4 net exchange.

To calculate net exchange observations, the following hydrologic components were ignored: storage in the canals; direct rainfall onto canals and evaporation out of the canals; and internal flows in primary, secondary, and tertiary canals. Estimated net exchange observations were determined using structure inflows and outflows at basin boundaries (Langevin, 2001; Lohmann and others, 2012). Measured structure flows were acquired from the SFWMD DBHYDRO database. Calculated net exchange for a surface-water basin was assumed to be the difference between the sum of structure inflows and the sum of structure outflows for that basin.

The model simulates the daily volumetric exchange of water between the aquifer and the canal cells. The daily net exchange rate of water into or out of the composite C-4 and C- 6 canals was extracted from the model results. Comparisons between observed and simulated net exchange show that the model simulates seasonal fluctuations that are similar to observed values for both basins (fig. 16). A 
positive exchange represents a net loss of water from the canal and net gain in the aquifer for the basin (recharge), whereas a negative exchange represents a net loss of water from the aquifer and net gain in the canals for the basin (discharge). Monthly volumetric rates for estimated observed net exchange were used to evaluate model performance to reduce noise associated with canal storage effects, direct recharge and evaporation, and internal canal flows within the basin. ME, MAE, and $\mathrm{R}^{2}$ statistics were also calculated for the net exchange comparisons (fig. 16). In general, simulated net exchange appears to match the general seasonal trend reasonably well, although the model does tend to underestimate canal losses for the $\mathrm{C} 6$ basin and overestimate canal losses for the $\mathrm{C} 4$ basin.

\section{Comparison of Dry and Wet Season Groundwater-Level Altitudes in Miami-Dade County}

A comparison between potentiometric surfaces generated from observed data and potentiometric surfaces generated from simulated water levels shows that, over most of the study area, differences in water levels are within $1 \mathrm{ft}$. Average groundwater levels were calculated from the transient model results for May (dry season) and November (wet season), 1998. For purposes of comparison, published water-table altitudes (Sonenshein and Koszalka, 1996) for May and November 1993 were interpolated to grid-cell centers. Although the year 1993 does not fall within the transient model period, the year 1998 was shown to be most similar to the year 1993 based on a comparison of average annual canalstage levels at a control structure on the L-30 Canal. Simulated daily water levels in the aquifer during May and November 1998 were averaged for each grid cell, and water levels during May and November 1993 from Sonenshein and Koszalka (1996) were subtracted to calculate difference maps (figs. 17 and 18). Water-level discrepancies are generally greater in the north, east, and far south of the model domain and near supply well fields than in the area of interest.

\section{Estimation of Well-Field Capture Zones and Drawdown}

Once the model was calibrated to groundwater heads and net exchange, steady-state simulations representing a range of hydrologic conditions were executed to estimate travel-time capture zones for $10,30,100$, and 210 days, and 0.25 -ft and 0.1 -ft drawdown contours for the well fields. In addition, two scenarios representing (1) seepage mitigation controls and (2) lake expansion were simulated, and the resulting capture zones and drawdown contours were compared to the results of the system without these proposed modifications.

\section{Methods}

Travel-time capture zone and drawdown were simulated under steady-state conditions. A deterministic approach used the base-case distribution of hydraulic parameters, and the Monte Carlo simulations employed statistical variations of these parameters to investigate parameter uncertainty. To represent a range of hydrologic conditions, a dry, average and wet day were selected for the analysis. Maximum design-capacity pumping rates for all county supply well fields near and within the study area were used in order to estimate the largest extent of the capture zones and drawdown contours. Steady-state conditions were represented by converting boundary conditions (input using EVT, RIV, CHD packages for the transient simulation) to specified flux for the selected dry, average and wet days. To represent steady-state recharge for the average and wet hydrologic conditions, daily rainfall rates for the selected average and wet-condition days were annualized. For the dry conditions, the steady-state rainfall rate used was zero. 


\section{Lake Representation-Bulk Hydraulic Conductivity Calculation}

In the transient model, it was assumed that quarry lakes excavated the full thickness of the Biscayne aquifer. Lake depths in the steady-state scenario models were adjusted to improve the accuracy of lake volumes and simulated travel times and drawdown.

Quarry lake depths for the NWWF were compiled by Miami-Dade County Department of Regulatory and Economic Resources (RER) and utilized to create lake-bottom spatial coverages. Lake depths were based on bathymetric maps and rock-mining permits (J. Baker, Miami-Dade Department of Regulatory and Economic Resources, unpub. data, 2011). A permitted lake depth of $60 \mathrm{ft}$ below land surface was assumed for lakes that lacked bathymetry information or permit records. For lakes near the WWF, available bathymetry was utilized for the two southernmost lakes (Solo-Gabriele, 2000). RER provided a bathymetric survey for the northernmost lake, and the average depth of this lake was used for the smallest lake directly south of it. Although the lake spatial coverage used in the steady-state simulations was generated in 2004, bathymetric surveys were not necessarily collected in the same year. The available lake-bottom data were used with the general assumption that the lake depths in 2004 were the reported surveyed depths.

Lake-bottom altitudes were calculated for each grid cell by intersecting the grid cell centroids with interpolated raster datasets developed from the bathymetric points. Where aerial lake data indicated expansion of a lake after 2004, only bathymetric data within the 2004 lake polygon were utilized. On a cell-by-cell basis, lake depths were subtracted from the estimated thickness of the Biscayne aquifer to yield the thickness of the Biscayne aquifer in each model cell beneath the lakes.

To represent the lakes accurately in a one-layer model, a bulk hydraulic conductivity value was calculated for lake cells. The calculation used lake depth, an assumed 328,084-ft/d (100,000-m/d) lake hydraulic conductivity, the underlying aquifer thickness and the Biscayne aquifer hydraulic conductivity obtained from the corresponding transient model cell in the base-case simulation (fig. 11). The bulk hydraulic conductivity was calculated using:

$$
K_{\text {bulk }}=\frac{K_{\text {aquifer }} \times b_{\text {aquifer }}+K_{\text {lake }} \times b_{\text {lake }}}{b_{\text {total }}}
$$

where

$K_{\text {bulk }} \quad$ is the bulk hydraulic conductivity of the cell used in the hydrologic scenario models, in feet per day;

$K_{\text {aquifer }} \quad$ is the hydraulic conductivity of the aquifer beneath the lake, in feet per day;

$b_{\text {aquifer }} \quad$ is the thickness of the aquifer beneath the lake, in feet;

$K_{\text {lake }} \quad$ is $328,084 \mathrm{ft} / \mathrm{d}(100,000 \mathrm{~m} / \mathrm{d})$;

$b_{\text {lake }} \quad$ is the thickness of the lake in feet; and

$b_{\text {total }} \quad$ is the total sum of $b_{\text {aquifer }}$ and $b_{\text {lake }}$. 


\section{Determination of Drawdown and Travel-Time Capture Zones}

Drawdown was calculated as the difference between heads from the steady-state simulation without pumping and heads from the steady-state simulation with maximum design-capacity pumping. Drawdown contours of $0.25 \mathrm{ft}$ and $0.1 \mathrm{ft}$ were evaluated.

Groundwater flow velocities were calculated by MODPATH 5.0 using cell-by-cell Darcy fluxes from MODFLOW-2005 divided by the specified effective porosity values used with MODPATH for each model cell. Particles were tracked backwards using MODPATH 5.0 until they discharged to boundaries or internal sources or sinks. The weak sink option was used in MODPATH, which allows particles to pass through cells with an internal boundary condition, such as a cell that has a well (specified flux) or canal (head-dependent flux). This allows some particles to pass beneath canals (representing underflow) or move past a low discharge well, rather than terminate at the cell with the applied boundary condition. Along the L-30 and L-31N Canals, which are at the western model boundary, particles terminate at the canal because the cells to the west are inactive. The canals provide a strong head control, thus the pathlines backtracking from the well were tested and shown to be unaffected even if the aquifer to the west is set to be actively simulated. Particles that terminate at this boundary, however, may have been able to move past this boundary, indicating that they may have moved from the natural wetlands towards the well field, if this area were actively simulated (Appendix 3).

Particles were placed around individual public-supply wells in the NWWF and WWF areas in all steady-state simulations. A total of 600 particles were placed along the cell faces containing supply wells in the NWWF and a total of 120 particles were placed along the cell faces containing supply wells in the WWF. Particles were then tracked backwards in time until they reached internal sources or boundaries. Forward particle tracking may yield different results than backward tracking, particularly in complex three-dimensional simulations (Barlow, 1997). Groundwater flow in the Biscayne aquifer is predominantly horizontal and the model used in this study is two-dimensional. A forward-tracking analysis was used for the one-layer model with canal cells in the supplemental simulations discussed in Appendix 1. Capture-zone results from this forward tracking simulation were not markedly different than results from an analogous backward-tracking simulation. Additionally, with the weak sink option, particles did travel from areas beyond the test canals through the weaker canals (these were internal to the boundary of the actively simulated area) moving towards the well.

For particles that travel through lakes, particle endpoints were calculated using a post-processing technique that applied residence-time adjustments (Chin and others, 2010) (Appendix 6) to account for transport in open water. Residence times of lakes were calculated by dividing the lake volume by the simulated steady-state lake outflow into the surrounding aquifer. Lake volumes were calculated using lake-bottom altitude data provided by RER. Lake volumes were unchanged between all simulations, whereas lake outflows were different in each simulation and calculated using ZONEBUDGET (Harbaugh, 1990). The cell-by-cell flow file from the maximum design-capacity pumping steady-state run was adjusted to calculate flows from just the lakes (as opposed to total flows between cells in the one-layer model) by multiplying lake-cell flows by the ratio of the product of the lake thickness $\left(b_{\text {lake }}\right)$ and the lake hydraulic conductivity $\left(K_{\text {lake }}\right)$ to the total Biscayne aquifer transmissivity. This adjusted cell-by-cell flow file was used as the input into ZONEBUDGET. The particle locations throughout time in the steady-state models were assumed to follow the actual particle pathlines through the lakes, although the lakes actually have more complicated mixing dynamics. The use of a residence time is one way to implement lake mixing without explicitly simulating the mixing process because a residencetime approach assumes the lake is well mixed. 
Residence times were calculated and used to adjust the particle locations by determining where adjusted particles would be located at 10,30, 100, and 210 days. Once a particle was tracked backwards to a lake, the particle location was adjusted to either the inflow side of the lake, if the residence time was such that the particle was located inside the lake at 10,30,100, or 210 days, or allowed to travel past the inflow of the lake and into the aquifer beyond, if the residence time was such that the particle was no longer inside the lake during the 10-, 30-, 100-, or 210-day period being tracked. For example, if a particle reached a lake within 10 days and this lake had a residence time of 90 days, the particle would need to be tracked backwards for an additional 110 days from the inflow side of the lake to obtain the 210-day capture-zone location. For the 30-day capture zone, however, the particle location would be the inflow point of the lake (which corresponds to where the particle would ultimately exit the lake when tracked backwards) because the residence time (90 days) and tracking time (10 days) are collectively larger than the required capture-zone endpoint (30 days). This residence-time approach is conceptually more correct than assuming porous media flow and a porosity of 1.0, because the latter does not account for mixing. Further information and justification on the particle post-processing method is discussed in Appendix 6. Finally, ending particle locations for specified times were plotted on a map to yield a spatial estimate of capture zones for the individual well fields.

Steady-state deterministic simulations under different hydrologic conditions were conducted using the base-case horizontal hydraulic conductivity field, with bulk hydraulic conductivities for lake cells, and a uniform value of 0.12 for the effective porosity of the Biscayne aquifer and 1.0 for lakes. These base-case deterministic simulations were compared with Monte Carlo simulations to evaluate the benefits of considering parameter uncertainty using the Monte Carlo analysis compared to the traditional deterministic approach.

\section{Evaluation of Uncertainty Using Monte Carlo Analysis}

Hydraulic conductivity and effective porosity are two physical parameters that are important in controlling groundwater flow and transport velocity. Although these parameters are estimated at APT locations, a large degree of uncertainty typically exists for parameter values between APT locations, while a smaller measurement-error uncertainty is present at those locations. A Monte Carlo analysis was performed to estimate capture zones and drawdown while considering uncertainties in hydraulic conductivity and effective porosity. A typical Monte Carlo analysis evaluates the effect of parameter uncertainty on model results by simulating a large number (hundreds or thousands) of realizations for which parameters are varied according to an assumed distribution. For this investigation, horizontal hydraulic conductivity and effective porosity were both varied. Canal bed conductances are also assigned the value of the aquifer hydraulic conductivity of the cell in which the RIV boundary condition is applied, so they vary as well Preliminary analyses indicated that 10,000 stochastic runs would be required to accommodate sample parameter uncertainty. Therefore, 10,000 conditioned hydraulicconductivity fields were created, 10,000 RIV Packages were created based on these conductivity fields, and 10,000 effective porosity values were sampled from a distribution representative of field and literature values. Each of the 10,000 realizations was simulated for each selected hydrologic condition.

Accounting for Uncertainty in Spatial Distribution of Hydraulic Conductivity

Aquifer performance test data (Fish and Stewart, 1991; Renken and others, 2008), which were used to create the base-case hydraulic conductivity field (fig. 11), were also used to condition the 10,000 hydraulic conductivity realizations. Horizontal hydraulic conductivity fields were generated using the 
sequential Gaussian simulation (SGSIM) method in PEST's FIELDGEN utility, which creates stochastic fields using a variogram model and conditioning data points (Deutsch and Journel, 1998; Doherty, 2010). Specifically, random variability multiplier arrays were created using the SGSIM method. The hydraulic conductivity field realization used in each model simulation was then calculated by multiplying the base-case hydraulic conductivity field by the stochastically generated multiplier array:

$$
K_{h_{r}(i, j)}=m_{r(i, j)} K_{h_{B C}(i, j)} .
$$

where for each realization $r$,

$$
\begin{array}{ll}
\quad i & \text { is the model row number, } \\
& \text { is the model column number, } \\
K_{h_{r}(i, j)} \quad \text { is the horizontal hydraulic conductivity for cell }(i, j), \\
m_{r(i, j)} \quad \text { is the multiplier for cell }(i, j) \text {, and } \\
K_{h_{B C}(i, j)} \quad \text { is the base-case horizontal hydraulic conductivity field interpolated from Fish and }
\end{array}
$$$$
\text { Stewart (1991) and Renken and others (2008) for cell }(i, j) \text {. }
$$

The variogram used in the SGSIM controls the variability and correlation structure of the stochastic fields. For this study, an exponential variogram with a correlation length of 13,123 ft $(4,000 \mathrm{~m})$ was used to generate the multiplier arrays. This correlation length was selected by constructing a variogram through curve-fitting based on the percentage of Biscayne aquifer flow zone thicknesses to the total thickness of the aquifer as defined in Cunningham and others (2006a, b). At APT locations (conditioning data), the multiplier array was assigned an expected value of 1.0. This assignment results in a mean hydraulic conductivity at APT locations that equals the hydraulic conductivity derived from APTs. The SGSIM variogram included a log-based nugget of 0.01 to represent APT measurement error. For example, for an APT-measured hydraulic conductivity value of $6,484 \mathrm{ft} / \mathrm{d}(1,976 \mathrm{~m} / \mathrm{d})$, the log-based nugget of 0.01 results in a 3-standard deviation hydraulic conductivity range between approximately 3,250 and $12,937 \mathrm{ft} / \mathrm{d}$. The sill represents the total variance of the multiplier array for distances longer than the variogram range. A log-based sill of 0.1 was used that allows hydraulic conductivity to vary within the range of approximately 730 and 57,611 ft/d (3 standard deviations) about the mean of 6,484 ft/d. The maximum and minimum values for each of the 10,000 realizations of hydraulic conductivity were sorted and the 2.5 percentile, median, and 97.5 percentile of the maximums and minimums were determined to better understand the range of hydraulic conductivity (table 2 ). The maximum and minimum of each realization are extreme values at one individual grid cell and not representative of the majority of grid cell values for hydraulic conductivity, which will tend to be close to the mean value. Three realizations (fig. 19) are examples of the products of the multiplier array and the base-case hydraulic conductivity field. Lake bulk hydraulic conductivity has not been replaced where lakes are present in these three examples. 
All three realizations are unique, yet similar to each other in that areas of higher conductivity and lower conductivity are common to each of the three, because the conditioning values constrain the estimated conductivity at APT locations.

For cells with lakes, the hydraulic conductivity values from the base-case or 10,000 Monte Carlo realizations were not used directly. Instead, bulk hydraulic conductivities were calculated using the lake depth, lake hydraulic conductivity, and the aquifer hydraulic conductivity of the cell the lake is in for each realization. This was done in order to appropriately represent the high-conductivity lakes and their depths in each realization used in the model.

\section{Accounting for Uncertainty in Effective Porosity}

The uncertainty associated with effective porosity was evaluated concurrently with uncertainty in horizontal hydraulic conductivity. Unlike hydraulic conductivity realizations that contained variability throughout the model domain, a uniform effective porosity field was used in each realization. Although effective porosity is expected to vary spatially, and correlation between effective porosity and hydraulic conductivity in flow zones may exist, few data exist to determine the spatial variability of effective porosity. Use of a non-uniform effective porosity would have introduced an additional element of uncertainty. Based on a range of effective porosity values reported in the literature for the Biscayne aquifer-4 percent (Renken and others, 2008) to 20 percent (Langevin, 2001; Merritt, 1996, 1997)—a representative intermediate effective porosity value of 12 percent was chosen. For the base-case simulations, this porosity value was used, except in the lake cells where the effective porosity was set to 1.0 .

Effective porosity values were sampled from a lognormal distribution created using the PEST utility RANDPAR (Doherty, 2010). The seed for each of the 10,000 instances of RANDPAR was determined using a random number generator. The log normal effective porosity distribution (fig. 20) had a mean of 0.12 (log-transformed -0.92082) and a log-transformed standard deviation of 0.16. Most effective porosity values used in the 10,000 stochastic realizations centered around the mean value of 0.12 , with values from 0.04 to 0.36 falling within 3 standard deviations about the mean. Values used for all realizations ranged from 0.04 to 0.50 (fig. 20).

\section{Selection of Stress Period for Steady-State Particle-Tracking Simulation}

A variety of different hydrologic conditions were evaluated to account for all reasonable groundwater flow fields near the well fields. Dry conditions, defined as a period of no recharge, low aquifer heads and low canal stages, are expected to result in capture zones with the largest areal extent. Wet and average hydrologic conditions were also simulated to account for potential differences in flow directions and travel times. Stage levels for tailwater at the S-337 and G-119 control structures, which control surface-water levels near the NWWF and WWF, were used to guide the selection of representative daily hydrologic conditions during the 9-year transient model period (fig. 21). Control structure S-337 (tailwater) is located on the L-30 Canal (fig. 8) northwest of the NWWF, and control structure G-119 (tailwater) is located on the Tamiami Canal north of the WWF. Stage data from the G-119 structure were used to select wet, average, and dry days that would be used to create steady-state models to simulate these different conditions, and data from the S-337 structure were used to verify the selected days.

Dry hydrologic conditions were evaluated using June 19, 2004, when the minimum stage value for the 9-year transient period was recorded at G-119 and a low stage was recorded at S-337 (fig. 21). 
Average hydrologic conditions were determined by selecting a day, December 19, 2002, when observed tailwater stages were close to the average calculated tailwater stage at G-119. Wet hydrologic conditions were evaluated using October 16, 1999, when the maximum stage value for the transient period was recorded at both structures.

\section{Simulated Time of Travel and Drawdown for Dry, Average, and Wet Hydrologic Conditions}

Representative dry, average, and wet hydrologic steady-state conditions are simulated and results are compared herein to determine the largest combined area enclosed by capture zones and drawdown contours. Analyses included both deterministic and Monte Carlo simulations.

\section{Base-Case Deterministic Simulations}

For each of the three hydrologic conditions, a deterministic simulation was run. Simulated drawdowns were contained within the surrounding canals and comparable to one another for all three runs. Simulated backward-tracked particle positions for the base-case simulations indicate that the capture zones for the NWWF extend further to the west, and are generally more uniform and radial toward the west than toward the east (figs. 22, 23, and 24). Ambient flow direction in the aquifer is generally west to east, which increases the length of the path that a particle travels in a set amount of time, making the capture zone extent larger toward the west than the east. When a simulated particle reaches a lake, the residence-time adjustment effectively increases or decreases the areal extent of capture-zone contours when compared to particles that do not come into contact with lakes, depending upon the calculated residence time. This results in a generally more irregular shape of the capture zone east of the well field than west of the well field. In addition, the Snapper Creek Extension Canal, located east of the NWWF (fig. 8), maintains high water levels in the aquifer and acts as a strong sink for backward-tracked particles. The dry-conditions simulation (fig. 22) appears to yield more spatially extensive time-based capture zones when compared to average (fig. 23) and wet (fig. 24) conditions. This could be attributed to the strong influence on recharge by the canals during dry conditions. Particles reach the closest lake to the north of the NWWF within 10 days.

For the WWF, travel-time results for the three conditions are generally similar, with particles reaching a lake closest to the WWF within 100 days (figs. 22, 23, and 24). Capture zones for wet hydrologic conditions extend slightly farther to the north of the WWF than capture zones for dry and average hydrologic conditions (fig. 24), whereas capture zones for dry and average hydrologic conditions were generally more radially symmetric around the well field. This indicates that the capture zones for the WWF are more sensitive to recharge rates and fluctuations of canal stages than those for the NWWF.

In general, the 0.25 -ft and $0.1-\mathrm{ft}$ drawdown contours differ minimally between simulations for the three hydrologic conditions (figs. 22, 23, and 24).

\section{Monte Carlo Simulations}

The results from the base-case simulations represent deterministic outcomes for the capture zones and drawdown contours of the NWWF and WWF under different hydrologic conditions. These results only represent one possible realization of hydraulic conductivity, canal conductance, and effective porosity, and do not account for the effects of parameter uncertainty on model results. To address parameter uncertainty in model results, a set of 10,000 possible physical realizations using a 
reasonable range of hydraulic conductivity and effective porosity values was simulated for each of three hydrologic conditions.

Particle positions after 10,30,100, and 210 days of travel for the 10,000 dry hydrologic condition realizations generally cover a larger extent than those simulated for the base-case, dry conditions (figs. 22 and 25). The 210-day particle positions from the Monte Carlo simulations cover a larger areal extent than the deterministic base-case simulation particle endpoints because many of the 10,000 realizations have hydraulic conductivity and effective porosity values that differ markedly from base-case values. Many 100-day and 210-day capture-zone particles from the Monte Carlo simulations reach the western model boundary (fig. 25), whereas the 100-day and 210-day capture-zone particles for the base-case deterministic run do not (fig. 22). The Snapper Creek Extension Canal east of the NWWF functions as a strong sink for the backward-tracked particles limiting their movement to the east of the NWWF in both the base-case and Monte Carlo simulations. The Snapper Creek Extension Canal is reached by backward-tracked particles within 100 days (fig. 25). Several lakes surrounding the NWWF were reached by backward-tracked particles within 10 days. Particles travel to lakes closest to the WWF within 10 and 30 days and many particles tracked backwards to the western boundary condition within 100 days.

A statistical technique developed by Varljen and Shafer (1991) was utilized to statistically evaluate results from the 10,000 individual simulations for each hydrologic condition. The approach uses particle endpoints to delineate median capture-zone contour lines and the 95-percent CI zone of uncertainty. Particle endpoints are grouped into radial classes based on a specified class size (fig. 26). The class size must be small to satisfy the assumption that radial differences between particles are small, but also large enough to produce smooth contour lines.

Relative to the spatial center of withdrawals for each well field, particles were sequentially ordered in the counter-clockwise direction starting at the 0-degree baseline (fig. 26). Particles were then separated into particle classes using 12,000 and 2,400 particles per class for the NWWF and WWF, respectively. This partitioning resulted in a total of 500 radial-slice particle classes for each well field. Within each class, particle distances from the centroid of withdrawals were used to statistically estimate travel-time capture zones. Varljen and Shafer's (1991) approach assumes that the particles are normally distributed in each direction; this assumption allows determination of the 95-percent CI zone of uncertainty using the calculated mean and standard deviation calculated for each particle class. However, because stochastic samples of effective porosity values are log-normally distributed and lakes noticeably change the areal extent of particles depending upon their residence time, the calculation of the 95-percent CI was based on the 2.5 and 97.5 percentiles of the cumulative distribution function of the particle endpoints in each class. The $50^{\text {th }}$ percentile in a given particle class is equivalent to the median distance for that travel time from the center of the well field. The 95-percent CI about this median was approximated by discarding those endpoints whose distances were less than the 2.5 percentile or greater than the 97.5 percentile within each radial class.

Simulated particle positions for dry conditions surrounding the NWWF for the 210-day capture zone for 100 of the 10,000 Monte Carlo simulations show the dense distribution of particles along the inflow boundaries of the lakes because of the residence-time adjustment of the particles tracked backwards through lakes (fig. 26). West of the NWWF supply wells, a more normal particle density distribution is evident.

For the steady-state dry, average, and wet hydrologic conditions, the 95-percent confidence interval, the median, and the base-case deterministic simulated particle endpoints for 210, 100, 30, and 10 days are presented. In the absence of lakes, the width of the 95-percent CI band reflects ambient flow conditions and uncertainty in the distribution of hydraulic properties and fluxes. In the presence of 
lakes, the width of the 95-percent CI band also reflects the uncertainty of residence times of the lakes and particle adjustments in post processing. The extent of the 95-percent CI contours differ depending on the hydrologic conditions.

Simulated median capture zones and 95-percent CI for dry hydrologic conditions were determined for 210,100, 30, and 10 days (figs. 27, 28, 29, and 30). The 210-day median capture zone for the Monte Carlo simulations are similar to but cover a larger spatial extent than the capture-zone particle positions for the base-case simulation, showing a greater extent toward the west than toward the east, (fig. 27). The width of the 95-percent CI is generally narrower north, east and southeast of the well field, where lake density is high, than west of the well field, because of (1) the high values of bulk hydraulic conductivities of lake cells, (2) an effective porosity of 1.0 for lakes in each realization, and (3) residence-time adjustments of the backward-tracked particles. In the area with lakes around the NWWF, the 95-percent CI is irregular for the 210-day and 100-day capture zones because individual particles may traverse more than one lake depending upon the lake residence times. The width of the 95percent CI is approximately $3 \mathrm{mi}$ west of the NWWF away from the lakes, indicating greater uncertainty in particle transport rates. As with the deterministic results, results from the Monte Carlo simulations indicate that particles reach lakes closest to the NWWF within 10 days (fig. 30).

Simulated median capture zones and 95-percent CIs for the average hydrologic conditions (figs. 31, 32, 33 and 34) are similar to those for the dry hydrologic conditions (figs. 27, 28, 29 and 30) although less spatially extensive. Simulated median capture zones and 95-percent CIs for wet hydrologic conditions (figs. 35, 36, 37, 38) are also similar to those for average conditions for the NWWF, but are substantially different in the cases of 210 days and 100 days for the WWF (figs. 31, 32, 35, and 36). The 95-percent CI bands for the WWF are more radially symmetric (except in the presence of lakes) for dry and average hydrologic conditions than for wet conditions, and extend farther to the north of the WWF for wet conditions than for dry and average conditions. For the NWWF, the outer 95-percent CI contour for the 210-day capture zone for dry hydrologic conditions almost fully encompasses the outer 95-percent CI contour for the 210-day capture zone for wet hydrologic conditions (fig. 39). For the WWF, the outer 95-percent CI contour for the 210-day capture zone for dry conditions does not fully encompass the outer 95-percent CI contour for the 210-day capture zone for wet conditions, which extends farther to the north (fig. 39). This finding indicates that the WWF has different recharge source areas depending on hydrologic conditions. Therefore, consideration of dry, average and wet hydrologic conditions is important when defining the maximum areal extent of capture zones for the WWF.

The 30-day capture zone for the WWF extends further toward the southwest for dry conditions than for average or wet conditions (figs. 29, 33, 37). The upper bound and median of the 95-percent CIs of the 30-day capture zone intersect a lake to the southwest of the WWF in this case, indicating faster transport of an introduced-chemical constituent from this lake to the WWF during the dry season than during the wet season.

The longer-travel-time capture zones, 210-day and 100-day, indicate the area surrounding the well fields that ultimately contribute groundwater to, and within which introduced-chemical constituents may reach well fields, whereas a 10-day travel-time capture zone, indicates an area within which introduced-chemical constituents may reach well fields in a short amount of time. Because of the residence-time approach to particle transport through lakes, which is based on residence-time mixing, any lake that intersects a capture zone can contribute to the well field within that capture-zone travel time. The nearest lake north of the NWWF is approximately $650 \mathrm{ft}$ from the closest supply well. The median and upper bound of the 95-percent CIs of the 10-day capture zone intersect this lake, for dry, average, and wet conditions. The results indicate that, because of the proximity of the lake to the 
NWWF, an introduced-chemical constituent could reach the NWWF within 10 days. Mixing processes in lakes and interactions between the lake and the surrounding aquifer introduce substantial uncertainty as to whether an introduced-chemical constituent in a lake will reach a well field within 10 days if the lake is within a 10-day capture zone. The possibility exists, nonetheless, and is worthy of consideration in management of wells that are close to lakes.

A composite 210-day capture zone for each well field was estimated by delineating the entire area in which particles were captured by each well field for both the dry and wet conditions. The upper bounds of the 95-percent CIs were overlaid on one another and the union of these two contour lines was formed (fig. 40). The composite capture zone shows the largest possible estimate (within the 95-percent CI zone of uncertainty) for 210 days of travel for both well fields based on this analysis. The composite 210-day capture zone differs substantially in shape and extent of the 210-day capture zones used by the county to establish Wellhead Protection Areas (figs. 3 and 40). There are substantial differences in the models used to generate the capture zones: (1) the model described herein accounts for the presence and transport of particles through lakes; (2) the Monte Carlo analysis used to determine a 95-percent CI accounts for uncertainty in hydraulic property distribution; and (3) the pumping rate for the WWF has been updated from $140 \mathrm{Mgal} / \mathrm{d}$ to $25 \mathrm{Mgal} / \mathrm{d}$ herein.

Drawdowns of $0.1 \mathrm{ft}$ and $0.25 \mathrm{ft}$ for the NWWF and WWF were also estimated using the Monte Carlo simulations. The median and 95-percent CI of the drawdown in each cell were first calculated for each of the hydrologic conditions (dry, average, and wet conditions). Then the median and the upper and lower bounds of the 95-percent CI were contoured for the 0.1-ft and 0.25-ft drawdowns for each of the hydrologic conditions (figs. 41, 42, and 43). There are minimal differences in the median and 95-percent CIs of the drawdowns for the different hydrologic conditions, likely because the the canals provide an unlimited source of water and the hydraulic conductivity is high, so pumping simply draws more water into the aquifer from the canals, maintaining the groundwater levels. Drawdown contours around the WWF coalesce with drawdown contours around other major well fields. For purposes of this analysis, a maximum design-capacity pumping rate was also used for well fields outside of the NWWF and WWF. Deterministic base-case simulated drawdowns (figs. 22, 23, and 24) coincide with the median drawdowns obtained from the Monte Carlo simulations and, therefore, are not shown.

Canals, both within the model domain and at the model boundaries, act as sources of water and particle discharge locations, as can be seen in drawdown and capture zone results. Except in a few cases, particles did not pass through internal canals, even when the weak sink option was used in MODPATH 5.0, which indicates internal canals act mainly as strong sources of water. Particles did, in some instances, pass through secondary internal canals when they were tracked to their final discharge locations beyond the 210-day extent shown. 


\section{Two Proposed Scenarios: Potential Effects of Seepage Mitigation and Lake Expansion on Capture Zones and Drawdown}

Two Monte Carlo simulations of three proposed anthropogenic changes to the natural environment were performed to evaluate their potential effects on well-field capture zones and drawdown. The first scenario investigates the effects of a recharge canal near the NWWF and restriction of flow from the western boundary west of the WWF. The second scenario evaluates the effects of proposed lake expansion on the capture zones and drawdown of both well fields.

\section{Proposed Scenario 1: Investigation of Effects of Seepage Mitigation}

Construction of a 7-mi-long slurry wall located west of the WWF has been proposed as a means to reduce the seepage of groundwater from ENP beneath the L-31N Canal. The proposed slurry wall would be constructed west of and parallel to the L-31N Canal between the Tamiami Canal and SFWMD primary canal structure G-211 (Lake Belt Mitigation Committee, 2009). A 1,000 ft section of this wall has been constructed to test the feasibility of this project. At the time of this writing, plans are in place to finish the 7-mi slurry wall section and possibly complete the wall to a greater subsurface depth than the test slurry wall. The existing test slurry wall section is 28 inches (in.) wide and $18 \mathrm{ft}$ deep and does not extend to the full depth of the Biscayne aquifer. The location of the proposed slurry wall between the L-31N Levee and the L-31N Canal is designed to reduce lateral seepage of groundwater beneath the canal from the Everglades toward the eastern part of the county, but not to inhibit the seepage from the canal into the aquifer. The L-31N Canal and undeveloped and protected areas west of the canal could potentially serve as sources of water east towards the WWF.

The model cannot explicitly evaluate the effects of a slurry wall west of the L-31N Canal, as the canal coincides with the western model boundary. The head-dependent flux boundary condition imposed at the L-31N Canal represents composite sources, leakage from the canal into the aquifer and underflow beneath the canal from the west. Sensitivity of the model results to the flux from the western model boundary was tested because the slurry wall could not be explicitly simulated.

The model was modified, using the MODFLOW-2005 Horizontal Flow Barrier (HFB) Package to cut-off flow from the western boundary, to evaluate the effect on capture zones and drawdown near the WWF. Using the HFB package, interfaces between the L-31N RIV cells and the cells east of these cells were assigned a barrier with hydraulic conductivity of zero to eliminate flow from the west (fig. 44). The effects on the capture zones and drawdown of the WWF were evaluated using a Monte Carlo analysis for the steady-state dry conditions.

A proposed recharge canal west of the NWWF along the Dade-Broward Levee was also included in this scenario (fig. 44). This canal is proposed to be connected to a northern adjoining interceptor canal and will recharge $60 \mathrm{Mgal} / \mathrm{d}$ from an external source of water. The recharge canal was represented in the steady-state seepage mitigation simulation with the WEL Package. The 219 cells along the length of this canal each contained a well that injected at a rate of $0.27 \mathrm{Mgal} / \mathrm{d}$. The MODPATH 5.0 option IFACE for particle tracking for these cells was set to 6 to ensure that particles could track backwards to the top of the cell to properly represent seepage from the recharge canal.

In the NWWF, the 210-day 95-percent CI and median capture zones differ from the dry conditions simulation that did not implement seepage mitigation (fig. 45). The presence of the recharge canal moves the extent of the simulated 210-day capture zone toward the east, away from the model boundary, relative to the 210-day capture zone in the absence of the recharge canal. Also shown in this figure are particle endpoints at the end of the steady-state Monte Carlo simulations (where particles 
eventually track backwards to water source locations sometime after 210 days). The endpoints represent the source areas within the simulated area for the NWWF under this seepage mitigation scenario. In the absence of the recharge canal, particles tracked backwards to the existing canals. With the introduction of seepage mitigation measures, some particles track backwards to the proposed recharge canal, although the majority of the particles track backwards to the western boundary. As this western boundary represents a composite flux of water from the L-30 Canal and west of the canal, particles that track backwards to this boundary may represent source-area water west of this canal. Results for the 100-, 30-, and 10-day capture zones and drawdowns for the seepage mitigation scenario (not shown) were not substantially different from those for the dry conditions without the slurry wall and recharge canal (figs. 28, 29, and 30).

Results of this simulation also indicate that the imposed flow barrier affects the extent of simulated capture zones around the WWF (figs. 46 and 47). The 95-percent CI upper bounds for the 210- and 100-day capture zones (figs. 46 and 47) for the seepage mitigation scenario expanded eastward and toward the north and south, and retracted from the west. Reduction of flow from the western boundary causes the WWF to capture more flow from all other directions, thus expanding the capture zone extent in those directions.

\section{Proposed Scenario 2: Investigation of Effects of Lake Expansion}

Substantial expansion of rock-mining activities in the Lake Belt area has been proposed that would increase the surface area of quarry lakes by an additional $25 \mathrm{mi}^{2}$ (fig. 48) (a 150-percent increase from 2004 conditions). This proposed expansion may have a measurable effect on particle travel times, the areal extent of capture zones, and drawdown for both the NWWF and WWF. The effect of this lake expansion was simulated stochastically assuming representative steady-state dry (June 19, 2004) hydrologic conditions.

The 210-day median and 95-percent CI upper bound for these simulations show a marked decrease in the areal extent for the travel-time capture zones of the NWWF (fig. 49), relative to the results of the dry conditions simulations. This is attributed largely to the increase in volume of these lakes in the subsurface near the NWWF. In the dry conditions simulations, backward-tracked particles moving to the west of the NWWF may have traversed no lakes or one lake; in the proposed lakeexpansion simulation, nearly all NWWF backward-tracked particles reach lakes in all directions from the well field. The bounds of the 95-percent CI for the NWWF are difficult to distinguish from the 210-day capture zone median because once a particle enters a lake, it moves to the inflow location for the duration of the residence time. The extent of the simulated $0.25-\mathrm{ft}$ drawdown contour was also reduced relative to simulations of the dry conditions without additional lakes, although not as substantially as the reduction of the capture zone extent.

Around the WWF, the 95-percent CI upper bound for the 210-day capture zone for steady-state dry conditions for the lake-expansion scenario is similar to results without additional lakes, except for the area west and northwest of the WWF (fig. 50). Expansion of the largest lake nearly to the L-31N Canal shifted the capture zone west of its location without lake expansion (fig. 50). The 0.1-ft drawdown decreased in extent near the largest lake northwest of the WWF, but otherwise remained unchanged throughout the well-field area when compared to the results from the dry conditions simulations (fig. 50). 


\section{Model Limitations}

The groundwater flow model and Monte Carlo simulations developed for this investigation were designed to estimate well-field flow regimes and travel times and were used to delineate capture zones and drawdown associated with the NWWF and the WWF. The model and methodology were designed to address specific objectives and are not necessarily designed to address other problems or answer other questions in the study area, without consideration of the technical assumptions made for this particular investigation.

Model errors can mainly be attributed to limitations of the conceptual model and inaccuracies in representation of the aquifer input parameters and boundary conditions. Aquifer properties vary throughout Miami-Dade County and limited data (hydraulic conductivity, canal conductances, storage properties, and effective porosity) are available to characterize hydraulic parameters in each model cell. Even measured parameters are associated with varying degrees of uncertainty from measurement error, which can be considerable in some cases. Transmissivity estimates derived from aquifer performance tests can range over orders of magnitude depending on the type of test, equipment, aquifer heterogeneity, method of analysis, and conditions during the test. Hydraulic conductivity derived from transmissivity estimates requires an assumption of the thickness of the contributing zone, which is not known in all locations where transmissivity data are derived from field tests. The conceptual model developed in this investigation was based on available estimates for these input parameters, with a built-in level of measurement error in some instances (implemented by use of a nugget in the variogram for hydraulic conductivity realizations) to stochastically estimate well-field capture zones and drawdown and quantify the uncertainty. Capture zone estimates are sensitive to hydraulic conductivity and effective porosity values and are therefore sensitive to any potential errors in estimation of these values that are incorporated in the 10,000 realizations used in the Monte Carlo analysis.

MODFLOW-2005 is designed for simulating flow in aquifers under laminar, non-turbulent flow regimes and is based on the assumptions of Darcy's law. In fact, the karstic Biscayne aquifer is known to be highly heterogeneous and anisotropic, with the presence of high-porosity, high permeability, flow zones near the NWWF and WWF (Shoemaker and others, 2008a). A limitation of the model is that it does not account for the possible existence of turbulent, non-Darcian flow, especially near the well fields during changes in pumping conditions. With turbulent flow, the linear relation between specific discharge and the hydraulic gradient in Darcy's law may not apply at high velocity. Turbulence was not considered because steady-state models were used in this analysis.

The spatial distribution and variability of hydraulic properties generally contribute substantial uncertainty in hydrologic models. For this model, hydraulic conductivity values are derived from limited number of APTs at specific locations. These values vary over several orders of magnitude and may differ over short distances. Hydraulic conductivity in areas lacking data is uncertain. Furthermore, estimated values of hydraulic conductivity are subjected to error in measured field parameters and assumptions made about the flow system when calculating transmissivity from field test data. Derived conductivity values usually represent a composite value for the entire aquifer thickness, although observations of stratiform flow zones indicate vertical heterogeneity in conductivity. Effective porosity cannot be measured directly, and may be considerably different than measured porosity, and there are few transport data with which to calibrate effective porosity. Effective porosity may also be spatially variable and scale dependent. Uncertainty in hydraulic conductivity (including values used as canal conductances) and effective porosity in the model were addressed using the Monte Carlo approach. The Monte Carlo simulation results, although accounting for a reasonable range of variation of the lateral distribution of hydraulic conductivity and effective porosity values, may also be sensitive to the nugget 
and sill values specified in the variogram model used to generate the 10,000 individual fields of hydraulic conductivity.

Although multiple flow zones are known to exist at some locations in the Biscayne aquifer, a one-layer model was used in this investigation because (1) the distribution and connectivity of individual flow zones across the model area is unknown, (2) few water-level data for individual flow zones exist in the study area with which to constrain model calibration, (3) to attempt to simulate individual flow zones would introduce substantially more uncertainty to the model, and (4) a simplification of the system made the stochastic approach more tractable. Development and calibration of a three-dimensional groundwater flow model that represents multiple flow zones is not possible based on present understanding of flow zone continuity and hydraulic conductivity. Observed datasets are not available to calibrate individual flow zones, and this precludes formal quantification of uncertainty in capture zones. The flow zones have not been mapped over the entire study area; there are only a few monitoring wells that measure water levels of specific flow zones; and few APT data exist in the study area to constrain vertical and horizontal hydraulic conductivity estimates of layers representing individual flow zones. The effect of the presence of flow zones on the extent of travel-time capture zones was implicitly included in the analysis by using a large range of effective porosity values. Although analyses indicated the travel-time capture zones and drawdown for a one-layer model differ somewhat from those for a multi-layer model (Appendix 1), one-layer models with a composite hydraulic conductivity that represent multiple lithologies have been used to simulate flow for the surficial aquifer system of Florida at a regional-scale (Sepulveda and Kuniansky, 2010; Sepulveda and others, 2012). While simulating multiple layers may improve precision of particle tracking, the decision was made to simplify representation of the Biscayne aquifer with a one-layer model to limit uncertainty, making the stochastic approach more tractable.

The model developed in this study may not be appropriate to address questions regarding ultimate sources of groundwater to the well fields from west of the model boundary. Many of the Monte Carlo simulated particle tracks for longer travel times terminate in the western boundary of the model (L-30 and L-31N Canals). These hydrologic features separate the urban part of Miami-Dade County from the Everglades National Park and Water Conservation Area 3B, yet studies indicate that underflow may occur beneath the canals from the western wetland areas (Cunningham and others, 2006; Sonenshein, 2001). Field tests and vertical-head data are required to better characterize the temporal and spatial distribution of underflow. A primary objective of this study was to determine capture zones within the urban part of the study area. Therefore, detailed simulation of contributing areas within the Everglades and the Water Conservation Areas was not within the scope of this study. The headdependent boundary conditions at the western model boundary are designed to represent all flow coming from the canals and under the canals from the Everglades and Water Conservation Areas. Particles that track backwards to this western model boundary indicate that the source area could be either the canal or west of the canal.

Simplifications were made to boundary conditions that affect recharge and discharge. Areal recharge is a function of precipitation and evapotranspiration. Precipitation and evapotranspiration rates were applied uniformly within the model domain, although they are known to be spatially variable. Canal stages and conductances of canal beds also affect recharge and discharge to the system. Errors in canal stage values are possible, particularly for smaller secondary canals where stage data were not directly available, or in ungaged reaches. Canal bed conductances, while calibrated, are largely unknown, and contribute uncertainty to the calibrated recharge. Explicit simulation of runoff and dynamic surface-water flow could improve the distribution of canal stages and thus the estimates of recharge, but were deemed beyond the scope of this study. Results of these analyses should be 
considered in light of the considerable uncertainty in the controls on recharge and discharge in the system.

Mixing within lakes was not explicitly simulated in the model. Instead, a lake-residence time was incorporated, using an approach modified from Chin and others (2010), to estimate particle transport through lakes for the Monte Carlo analysis (Appendix 6). This adjustment was based on the assumption of lake mixing occurring over the period of the residence time, which may not be a valid assumption as the residence time is a measure of the average amount of time that water is retained in a lake. Through the Monte Carlo analysis, a range of residence times was calculated for each lake, based on the flow rate from the lake to the aquifer, which changed between each realization. Furthermore, the pathlines of backward-tracked particles through lakes are different between each realization. Therefore, although a simple residence-time approach to lake transport was utilized, the Monte Carlo analysis considers the uncertainty of particle pathlines and lake-aquifer exchanges, and therefore, ensures that the greatest possible capture area is estimated.

A further assumption made in the modeling process is that groundwater recharge from rainfall occurs instantaneously. The unsaturated zone is not explicitly simulated because delay of infiltrating rainfall in the unsaturated zone is expected to be less than a day and is not expected to substantially affect particle transport compared to other water-budget components.

The no-flow boundary condition at the bottom of the model assumes no water is exchanged between the lower Biscayne aquifer and the underlying gray limestone aquifer as there is a low-permeability confining unit that limits leakage between the two aquifers (Fish and Stewart, 1991). This no-flow boundary is also used in previous models (Langevin, 2001; Lohmann and others, 2012). There is likely some heterogeneity in the properties of the confining unit and leakage may occur but leakage is considered to be small relative to other sources/sinks in the model.

Particle tracking evaluations were made for steady-state conditions using MODPATH, which accounts for advective transport, but does not consider dispersive transport. Advective particle tracking is commonly used to determine well-field capture zones and was used to develop the existing capture zones for the study area. Results of tracer tests near the NWWF indicate that dispersive transport is estimated to be small compared to advective transport at a scale of about $100 \mathrm{~m}$ (Renken and others, 2008; Shapiro and others, 2008). These results may not apply at the scale of this investigation, nonetheless the assumption was made that dispersion contributed minimally to the reach of individual pathlines. MODPATH can simulate particle tracking in both steady-state and transient flow fields, but results from transient particle tracking were assumed to fall within the results from the steady-state Monte Carlo analysis. Backward particle tracking simulations were analyzed with the Monte Carlo approach; forward particle tracking simulations were not analyzed, except as discussed in Appendix 1 to verify backward-tracked particle pathlines. It is possible that forward tracking my provide different results than backward tracking, but the results in Appendix 1 indicate that, in this case, the results would be essentially the same.

Simulated results of how the system would respond to proposed modifications should be interpreted with caution because the model was not designed specifically to evaluate those conditions. Groundwater recharge from a proposed recharge canal was modeled using the MODFLOW Well (WEL) Package, allowing direct input of a uniform rate of water entering the aquifer along the entire length of the proposed canal. In reality, recharge from the canal may not occur at this maximum specified rate and may not be controllable, and also may not be equally distributed along the length of the canal, as it is in the model.

The proposed slurry wall could not be explicitly simulated because (1) the location of the proposed structure is beyond the model boundary, and (2) the one-layer model cannot directly account 
for a flow barrier that is installed only partially through the aquifer. Application of a horizontal flow barrier on the east side of the western head-dependent flux boundary effectively cut off flow from the west, and capture-zone extents and drawdowns were shown to be sensitive to this change in the flow field.

Sensitivity analyses are used to determine the impact that parameter uncertainty may have on model predictions. A quantitative predictive sensitivity analysis to evaluate to what extent individual parameters and stresses affect the capture zones was not formally conducted. Instead, the Monte Carlo analysis incorporates uncertainty in the hydraulic properties, and was used in this investigation to investigate parameter uncertainty effects on capture zones and drawdown for steady-state wet, average and dry hydrologic conditions.

\section{Summary and Conclusions}

The U.S. Geological Survey investigated groundwater flow paths in the urban areas near the Northwest (NWWF) and West (WWF) Well Fields in Miami-Dade County, Florida, to evaluate traveltime capture zones and drawdowns. A one-layer groundwater flow model of the Biscayne aquifer was developed for the eastern part of Miami-Dade County. The model documented herein was modified from a previously existing integrated surface-water/variable-density groundwater flow model (Lohmann and others, 2012). The model accounts for daily changes in interactions between the aquifer and surface-water features, recharge and evapotranspiration, changing tidal stages in Biscayne Bay, as well as groundwater pumping. The model was calibrated to transient daily conditions during January 1996 to December 2004 by adjustment of evapotranspiration extinction depth, ungaged secondary and tertiary canal stages, canal conductance, and hydraulic conductivity. Calibration targets were observed groundwater levels and net exchanges between the canals and aquifer in primary canal basins.

The model was modified to represent steady-state dry, average and wet hydrologic conditions to determine travel-time capture zones and drawdown for the NWWF and WWF. Canal stage data from two control structures near the NWWF and WWF were used to select one day each representing dry, average, and wet hydrologic conditions in the study area. Model input for these 3 days were selected from the transient model, and adjustments were made to annualize the rainfall rates for each of these hydrologic conditions. To simulate transport more accurately through the lakes, bulk hydraulic conductivities were calculated from information on lake depths and aquifer thicknesses and applied to model cells with lakes. Using the annualized rainfall rates and bulk hydraulic conductivities for lakes, three steady-state simulations representing dry, average, and wet hydrologic conditions were run with and without well-field pumping.

To account for uncertainty in the spatial distributions of hydraulic conductivity, effective porosity, and canal conductances, 10,000 stochastic realizations of these model input parameters were created based on published data from field tests and documented models. For each of the three hydrologic conditions, the 10,000 realizations were simulated, and the 10,000 results were used to calculate drawdown and to simulate particle pathways. The median and 95-percent confidence intervals (CI) of the 0.25 -foot (ft) and 0.1-ft drawdowns were contoured for each of the three hydrologic conditions. MODPATH 5.0 backward particle tracking was applied for each simulation, and particle endpoints through lakes were further adjusted to account for the lake residence time, to estimate the median and 95-percent CIs of the 10-, 30-, 100-, and 210- day capture zones for each of the three hydrologic conditions. Each particle path through a lake was adjusted to account for lake residence time without explicitly simulating mixing in the lake. 
Two scenarios were simulated to investigate the effects on capture zones and drawdown of (1) two seepage mitigation structures, and (2) future proposed expansion of man-made quarry lakes. The mitigation scenario simulated the addition of a recharge canal near the NWWF and a flow barrier west of the WWF, effectively cutting off flow from the western boundary. The lake-expansion scenario simulated increasing the spatial extent of the lakes by 25 square miles $\left(\mathrm{mi}^{2}\right)$.

The results of this investigation indicate several considerations for management of the groundwater resources near the NWWF and WWF.

- Because the ambient groundwater-flow direction is generally from west to east near the well fields, the capture zones are more extensive toward the west than east of the well fields for all travel times and hydrologic conditions evaluated, particularly for the NWWF. The shape of the capture zones in areas with lakes is more irregular than in areas without lakes, because of the residence-time adjustment in lakes.

- In general, the deterministic and median and 95-percent CIs of the 0.25-ft and 0.1-ft drawdown contours differ minimally between simulations for the three hydrologic conditions, and the median CIs for the $0.25-\mathrm{ft}$ and $0.1-\mathrm{ft}$ drawdown contours are similar to the simulated drawdown contours for the deterministic base-case simulations.

- The capture zones for the NWWF show the same basic shape for dry, average, and wet hydrologic conditions, with slightly greater extent toward the west for drier conditions than for average and wet conditions.

- The simulated capture zones for the WWF indicate that recharge areas for this well differ slightly for dry and wet hydrologic conditions. The WWF capture zones, in general, are radially symmetric around the well field during dry hydrologic conditions, except where lakes are present west of the well field, but are slightly skewed toward the north during wet hydrologic conditions. The 30-day capture zone for the WWF extends into a lake southwest of the well field during dry conditions, indicating the possibility of faster transport of an introduced-chemical constituent from this lake to the WWF during the dry season than during the wet season.

- The 10-day travel-time capture zone indicates an area within which introduced-chemical constituents may reach well fields in a short amount of time. One lake, just north of the NWWF, is included within the 10-day capture zone for all three hydrologic scenario runs. Mixing processes in lakes are likely more complicated than represented herein and therefore, there is substantial uncertainty whether an introduced-chemical constituent in a lake will reach a well field within 10 days if the lake is within a 10-day capture zone, yet the possibility exists.

- In general, backward-tracked particles ultimately terminate at canals, even when the weak-sink particle-tracking option in MODPATH 5.0 is used, indicating that most canals in the study area act as strong sources of water. Westward-tracking particles can originate no further than the western model boundary, which is defined by the L-31N and L-30 Canals. Because the western boundary condition represents a composite flux from the canal and from groundwater entering the model domain beneath the canal from the west, particles that track backwards to this boundary could represent water originating from sources west of the boundary, from the canals themselves, or a combination of western sources and canals. 
- The composite 210-day capture zones differ substantially in shape and extent from the 210-day capture zones used by the county to establish Wellhead Protection Areas (WHPAs) because (1) the model described in this report has accounted for the presence and transport of particles through lakes, (2) a stochastic approach was used for these evaluations to determine 95-percent confidence intervals that accounted for uncertainty in hydraulic property distribution, and (3) the pumping rate used for the WWF in this analysis was substantially lower than that used to establish the original WHPAs.

- Alterations to the hydrologic system may affect the distribution of capture zones and drawdown contours. Simulation results show that (1) the recharge canal captures some particles that would have otherwise tracked back to the western boundary, and reduces the extent of the capture zones; (2) reduction of flow from the western boundary causes the WWF to capture more flow from all other directions, thus expanding the capture zone and drawdown extent in those directions; and (3) the addition of lakes resulted in a general decrease in the areal extent of capture zones and a decrease in the extent of the $0.25-\mathrm{ft}$ drawdown contour for the NWWF, expanded the westward extent of the capture zone around the WWF, and decreased the extent of the drawdown contour of the WWF.

- The model is limited by assumptions about the flow system, simplifications made in the conceptual model, and knowledge of the hydraulic properties of the units simulated. These include, among others: the distribution of hydraulic properties; the simulation of the Biscayne aquifer as a single composite layer; the proximity of the study area to the western model boundary; and the transport behavior in quarry lakes. While model results should be considered in light of these limitations, the Monte Carlo analysis incorporates uncertainty into the model predictions of capture zones and drawdown. This allows for calculation of confidence intervals of results, producing a more informative evaluation of the response of the hydrologic system to varying stresses and hydrologic conditions than an evaluation based solely on deterministic simulation results. 


\section{Selected References}

Anderson, M.P., Hunt, R.J., Krohelski, J.T., and Chung, K., 2002, Using High Hydraulic Conductivity Nodes to Simulate Seepage Lakes: Ground Water, v. 40, no. 2, p. 117-122.

Anderson, M.P., and Woessner, W.W., 1992, Applied groundwater modeling, simulation of flow and advective transport: San Diego, Calif., Academic Press, Inc., 381 p.

Bair, E.S., Safreed, C.M., and Stasny, E.A., 1991, A Monte Carlo-based approach for determining traveltime-related capture zones of wells using convex hulls as confidence regions: Ground Water, $v$. 29 , no. 6, p. 849-855.

Barlow, P.M. 1997, Particle-tracking analysis of contributing areas of public-supply wells in simple and complex flow systems, Cape Cod, Massachusetts: U.S. Geological Survey Water-Supply Paper 2434, $66 \mathrm{p}$.

Camp Dresser \& McKee Inc. (CDM), 1985, Groundwater flow model for the Northwest Well Field, Dade County, Florida: Consultant report prepared for Miami-Dade Department of Environmental Resources Management.

CH2MHill, 2001, Risk assessment and groundwater modeling of the Miami-Dade Northwest Wellfield: Report prepared for the Miami-Dade Department of Environmental Resources Management (DERM).

Chin, D.A., Iudicello, J.J., Kajder, K.C., Kelly, P.M., Porzilli, D.V., and Guha, H., 2010, Lake effect in wellhead protection: Journal of Water Resources Planning and Management, ASCE, May/June 2010.

Chin, D.A., and Patterson, R.D., 2005, Quantification of hydrologic processes and assessment of rainfall-runoff models in Miami-Dade County, Florida: U.S. Geological Survey Scientific Investigations Report 2004-5191.

Code of Miami-Dade County, Florida, 2009, Ordinance No. 09-27, accessed June 26, 2012, at http://library.municode.com/index.aspx?clientId $=10620$.

Cooper, R.P., and Lane, J., 1987, An atlas of eastern Dade County surface water management basins: South Florida Water Management District Technical Memorandum.

Cunningham, K.J., Carlson, J.L., Wingard, G.L., Robinson, Edward, and Wacker, M.A., 2004a, Characterization of aquifer heterogeneity using cyclostratigraphy and geophysical methods in the upper part of the karstic Biscayne aquifer, southeastern Florida: U.S. Geological Survey WaterResources Investigations Report 03-4208, 46 p.

Cunningham, K.J., Renken, R.A., Wacker, M.A., Zygnerski, M.R., Robinson, E., Shapiro, A.M., and Wingard, G.L., 2006a, Application of carbonate cyclostratigraphy and borehole geophysics to delineate porosity and preferential low in the karst limestone of the Biscayne aquifer, SE Florida, in Harmon, R.S., and Wicks, C., eds., Perspectives on Karst Geomorphology, Hydrology, and Geochemistry: Geological Society of America, v. 404, p. 191-208.

Cunningham, K.J., and Sukop, M.C., 2011, Multiple technologies applied to characterization of the porosity and permeability of the Biscayne aquifer, Florida: U.S. Geological Survey Open-File Report 2011-1037, 8 p.

Cunningham, K.J., Sukop, M.C., Huang, H., Alvarez, P.F., Curran, H.A., Renken, R.A., and Dixon, J.F., 2009, Prominence of ichnologically influenced macroporosity in the karst Biscayne aquifer:

Stratiform "super-K" zones: Geological Society of America Bulletin, v. 121, no. 1/2, p. 164-180. 
Cunningham, K.J., Wacker, M.A., Robinson, E., Dixon, J.F., and Wingard G.L., 2006b, A cyclostratigraphic and borehole geophysical approach to development of a three-dimensional conceptual hydrogeologic model of the karst Biscayne aquifer, southeastern Florida., U.S. Geological Survey Scientific Investigations Report, 2005-5235, 69 p.

Cunningham, K.J., Wacker, M.A., Robinson, Edward, Gefvert, C.J., and Krupa, S.L., 2004b, Hydrogeology and ground-water flow at Levee-31N, Miami-Dade County, Florida, July 2003 to May 2004: U.S. Geological Survey Scientific Investigations Map I-2846, 1 sheet.

Department of Environmental Resources Management, 1992, Modeling for the West Wellfield updated protection area: Miami-Dade County Department of Environmental Resources Management Technical Memorandum.

Deutsch, C.V., and Journel, A.G., 1998, GSLIB: Geostatistical software library: Oxford University Press, 384 p.

Doherty, J., 2010, PEST: Model independent paramater estimation, user documentation: Brisbane, Queensland, Australia, Watermark Numerical Computing.

Federal Register Notice, 1979, Biscayne aquifer; notice of determination: Notice FRL 1264-3, v. 44, no. 198, p. 58797-58798.

Fish, J.E., and Stewart, M.T., 1991, Hydrogeology of the surficial aquifer system, Dade County, Florida: U.S. Geological Survey Water-Resources Investigations Report 90-4108.

Florea, L.J., Cunningham, K.J., and Altobelli, S., 2009, NMR imaging of fluid exchange between macropores and matrix in eogenetic karst: Groundwater, v. 47, p. 382-390.

Franke, O.L., Reilly, T.E., Pollock, D.W., and LaBaugh, J.W., 1998, Estimating areas contributing recharge to wells, lessons from previous studies: U.S. Geological Survey Circular 1174, 14 p.

Franzetti, S., and Guadagnini, A., 1996, Probabilistic estimation of well catchments in heterogenous aquifers: Journal of Hydrology, v. 174, p. 149-171.

German, E.R., 2000, Regional Evaluation of Evapotranspiration in the Everglades: U.S. Geological Survey Water-Resources Investigations Report 00-4217, 48 p.

Giddings, J.B., Kuebler, L.L., Restrepo, J.I., Rodberg, K.A., Montoya, A.M., and Radin, H.A., 2006, Draft report of Lower East Coast subRegional (LECsR) MODFLOW Model Documentation, South Florida Water Management District, 294 p.

Guha, H., 2008, A stochastic modeling approach to address hydrogeologic uncertainties in modeling wellhead protection boundaries in karst aquifers: Journal of the American Water Resources Association, v. 44, no. 3.

Harbaugh, A.W., 1990, A computer program for calculating subregional water budgets using results from the U.S. Geological Survey modular three-dimensional ground-water flow model: U.S. Geological Survey Open-File Report 90-392, 46 p.

Harbaugh, A.W., 2005, Modflow-2005, The U.S. Geological Survey modular ground-water modelThe Ground-Water Flow Process, U.S. Geological Survey Techniques and Methods 6-A16.

Harvey, R.W., Metge, D.W., Shapiro, A.M., Renken, R.A., Osborn, C.L., Ryan, J.N., Cunningham, K.J., and Landkamer, L.L., 2008, Pathogen and chemical transport 
in the karst limestone of the Biscayne aquifer: 3. Use of microspheres to estimate the transport potential of Cryptosporidium parvum oocysts: Water Resources Research, v. 44, W08431, doi:10.1029/2007WR006060.

Hunt, R.J., Haitjema, H.M., Krohelski, J.T., and Feinstein, D.T., 2003, Simulating ground-water-lake interactions: Approaches and insights: Ground Water, v. 41, no. 2, p. 227-237.

Kerans and Tinker, 1997, Sequence stratigraphy and characterization of carbonate reservoirs: SEPM Short course notes, Vol. 40, $130 \mathrm{p}$.

Kuniansky, E.L., Gómez-Gómez, Fernando, and Torres-González, Sigfredo, 2004, Effects of aquifer development and changes in irrigation practices on ground-water availability in the Santa Isabel area, Puerto Rico: U.S. Geological Survey Water-Resources Investigations Report 03-4303, 56 p.

Lake Belt Mitigation Committee, 2009, Lake Belt Mitigation Committee meeting summary, April 17, 2009: Accessed March 9, 2010, at http://www.sfwmd.gov/portal/page/portal/pg_grp_sfwmd_watersupply/subtabs\%20\%20miamidadeco\%20\%20-\%20mitigation/tab1610177/meeting\%20summary4-17-09.pdf

Langevin, C.D., 2001, Simulation of ground-water discharge to Biscayne Bay, Southeastern Florida: U.S. Geological Survey Water-Resources Investigations Report 00-4251.

Lee, T.M., 1996, Hydrogeologic controls on the groundwater interactions with an acidic lake in karst terrain, Lake Barco, Florida: Water Resources Research, v. 32, no. 4, p. 831-844.

Lohmann, M.A., Swain, E.D., Wang, J.D., and Dixon, J., 2012, Evaluation of Effects of Changes in Canal Management and Precipitation Patterns on Salinity in Biscayne Bay, Florida, using an Integrated Surface-Water/Groundwater Model: U.S. Geological Survey Scientific Investigations Report 2012-5099, 94 p.

Marella, R.L., 2009, Water withdrawals, use, and trends in Florida, 2005: U.S. Geological Survey Scientific Investigations Report 2009-5125, 49 p.

McDonald, M.G., and Harbaugh, A.W., 1988, A modular three-dimensional finite-difference groundwater flow model: U.S. Geological Survey Techniques of Water Resources Investigations, book 6, chap. A1, 586 p.

Merritt, M.L., 1997, Simulation of the water-table altitude in the Biscayne aquifer, Southern Dade County, Florida, water years 1945-89: U.S. Geological Survey Water-Supply Paper 2458, 148 p.

Merritt, M.L., 1996, Numerical simulation of a plume of brackish water in the Biscayne aquifer originating from a flowing artesian well, Dade County, Florida: U.S. Geological Survey WaterSupply Paper 2464, 74 p.

Merritt, M.L. and Konikow, L.F., 2000, Documentation of a computer program to simulate lake-aquifer interaction using the MODFLOW ground-water flow model and the MOC3D solute-transport model: U.S. Geological Survey Water-Resources Investigations Report 00-4167, 146 p.

Parker, G.G., 1951, Geologic and hydrologic factors in the perennial yield of the Biscayne aquifer: American Water Works Association Journal, v. 8, p. 817-835.

Pollock, D.W., 1994, User's Guide for MODPATH/MODPATH-PLOT, Version 3: A particle tracking post-processing package for MODFLOW, the U.S. Geological Survey finite-difference ground-water flow model: U.S. Geological Survey Open-File Report 94-464, 6 ch. 
Prickett, T.A., and Lonnquist, C.G., 1971, Selected digital computer techniques for groundwater resource evaluation: Illinois State Water Survey Bulletin 55, Champaign, Ill.

Reese, R.S. and Cunningham, K.J., 2000, Hydrogeology of the gray limestone aquifer in southern Florida: U.S. Geological Survey Water-Resources Investigations Report 99-4213, 244 p.

Reese, R.S., and Richardson, Emily, 2008, Synthesis of the hydrogeologic framework of the Floridan aquifer system and delineation of a major Avon Park permeable zone in central and southern Florida: U.S. Geological Survey Scientific Investigations Report 2007-5207, 60 p., 4 pls., plus apps.

Reilly, T.E. and Pollock, D.W., 1993, Factors affecting areas contributing recharge to wells in shallow aquifers: U.S. Geological Survey Water Supply Paper 2412, 21 p.

Renken, R.A., Cunningham, K.J., Shapiro, A.M., Harvey, R.W., Zygnerski, M.R., Metge, D.W., and Wacker, M.A., 2008, Pathogen and chemical transport in the karst limestone of the Biscayne aquifer: 1. Revised conceptualization of groundwater flow: Water Resources Research, v. 44, W08429, doi: 10.1029/2007WR006058

Renken, R.A., Shapiro, A.M., Cunningham, K.J., Harvey, R.W., Metge, D.W., Zygnerski, M.R., Osborn, C.L., Wacker, M.A., and Ryan, J.N., 2005, Assessing the vulnerability of a municipal well field to contamination in a karst aquifer: Environmental and Engineering Geoscience, v. 11, no. 4, p. 319-331.

Sepúlveda, Nicasio and Kuniansky, Eve L., 2010, Effects of model layer simplification using composite hydraulic properties: Hydrogeology Journal, v. 18, p. 405-416.

Sepúlveda, Nicasio, Tiedeman, C.R., O’Reilly, A.M., Davis, J.B., and Burger, Patrick, 2012, Groundwater flow and water budget in the surficial and Floridan aquifer systems in east-central Florida: U.S. Geological Survey Scientific Investigations Report 2012-5161, 214 p.

Shapiro, A.M., Renken, R.A., Harvey, R.W., Zygnerski, M.R., and Metge, D.W., 2008, Pathogen and chemical transport in thekarst limestone of the Biscayne aquifer: 2. Chemical retention from diffusion and slow advection: Water Resources Research, v. 44, W08430, doi:10.1029/2007WR006059.

Shoemaker, W.B., Cunningham, K.J., Kuniansky, E.L., and Dixon, J.F., 2008a, Effects of turbulence on hydraulic heads and parameter sensitivities in preferential groundwater flow layers: Water Resources Research, v. 44, W03501, doi:10.1029/2007WR006601.

Shoemaker, W.B., Kuniansky, E.L., Birk, Steffen, Bauer, Sebastian, and Swain, E.D., 2008b, Documentation of a Conduit Flow Process (CFP) for MODFLOW-2005: U.S. Geological Survey Techniques and Methods 6-A24, $50 \mathrm{p}$.

Solo-Gabriele, H., 2000, An isotopic study of two rock mining lakes: Second interim technical report for isotope study, Phase I, Submitted to Kendall Properties and Investments, Inc., University of Miami Departmant of Civil, Architectural, and Environmental Engineering, Coral Gables, Fla.

Sonenshein, R.S., 2001, Methods to quantify seepage beneath Levee 30, Miami-Dade County, Florida: U.S. Geological Survey Water-Resources Investigations Report 01-4074, 36 p.

Sonenshein, R.S., and Koszalka, E.J., 1996, Trends in water-table altitude (1984-93) and saltwater intrusion (1974-93) in the Biscayne aquifer, Dade County, Florida: U.S. Geological Survey Open-File Report 95-705, 2 sheets. 
Snyder, D.T., Wilkinson, J.M., and Orzol, L.L., 1998, Use of a ground-water flow model with particle tracking to evaluate ground-water vulnerability, Clark County, Washington: U.S. Geological Survey Water-Supply Paper 2488, 63 p.

Starn, J.J., Bagtzoglou, A.C., and Robbins, G.A., 2010, Using atmospheric tracers to reduce uncertainty in groundwater recharge areas: Ground Water v. 48, no. 6, p. 858-868, doi:10.1111/j.17456584.2010.00674.x.

Starn, J. Jeffrey and Brown, Craig J., 2007. Simulations of Ground-Water Flow and Residence Time near Woodbury, Connecticut. Geological Survey (U.S.) Scientific Investigations Report 2007-5210, viii, $45 \mathrm{p}$.

Starn, J.J., Stone, J.R., and Mullaney, J.R., 2000, Delineation and analysis of uncertainty of contributing areas to wells at the Southbury Training School, Southbury, Connecticut: U.S. Geological Survey Water-Resources Investigation Report 00-4158, 53 p.

Swain, E.D., Howie, B., and Dixon, J., 1996, Description and field analysis of a coupled ground water/surface-water flow model (MODFLOW/BRANCH) with modifications for structures and wetlands in southern Dade County, Florida: U.S. Geological Survey Water-Resources Investigations Report 96-4118, $71 \mathrm{p}$.

U.S. Environmental Protection Agency, 1987, Guidelines for delineation of wellhead protection areas: Office of Ground-Water Protection, U.S. Environmental Protection Agency report no. 440687010.

Varljen, M.D., and Shafer, J.M., 1991, Assessment of uncertainty in time-related capture zones using conditional simulation of hydraulic conductivity: Ground Water, v. 29, no. 5, p. 737-748.

Wilson, J.D. and Naff, R.L., 2004, The U.S. Geological Survey modular ground-water model-GMG linear equation solver package documentation: U.S. Geological Survey Open-File Report 2004-1261, $47 \mathrm{p}$. 



\section{Appendix 1. Comparative analysis of a one-layer and a multi-layer representation of a hydrologic system}

A conceptual exercise was developed to evaluate whether a one-layer groundwater flow model that uses bulk aquifer properties can accurately estimate capture zones and drawdown for a heterogeneous, anisotropic aquifer composed of two groundwater flow zones and a relatively less permeable zone in between. A single-layer steady-state MODFLOW groundwater flow model (conceptual Model A) was created with a well located in the center of the domain and constant-head boundaries on the left- and right-hand boundaries (fig. 1-1). The grid consisted of 100 rows and 100 columns with 1,640-feet $(\mathrm{ft})(500$-meter $(\mathrm{m}))$ grid spacing in the $\mathrm{x}$ - and y-directions. The top altitude of the model was assigned a uniform value of $0.0 \mathrm{ft}(0.0 \mathrm{~m})$ and the bottom altitude was assigned a uniform value of $-69.0 \mathrm{ft}(-21.0 \mathrm{~m})$, similar to the surface and average bottom altitudes of the Biscayne aquifer (fig. 4). Constant-head cell boundaries were set to 0.0 IW

A second conceptual steady-state MODFLOW groundwater flow model (conceptual Model B) was developed containing three layers (fig. 1-1). A uniform horizontal grid discretization was used and specified constant-head cells on the left- and right-hand boundaries of the model in layer 1 were the same as those in Model A. The uppermost and lowermost layers of Model B represent continuous megaporosity flow zones mapped near the NWWF (Cunningham and others, 2006a, 2006b) and WWF. In this analysis, these flow zones were hypothesized to be well connected over the scale of the model domain. It was assumed that horizontal hydraulic conductivity in these two layers was considerably larger than in layer 2. This assumption corresponds well with a simplified conceptualization of the framework of the Biscayne aquifer near the NWWF and WWF (Cunningham and others, 2006; Renken and others, 2008) in which groundwater flow occurs primarily within the highly porous, touching-vug flow zones. The top and bottom altitudes of Model B were assigned the same values as those in conceptual Model A, with the top and bottom altitudes of the less permeable layer 2 set to $-10 \mathrm{ft}$ $(-3.048 \mathrm{~m})$ and $-45 \mathrm{ft}(13.716 \mathrm{~m})$, respectively.

Equivalent bulk hydraulic properties of horizontal hydraulic conductivity and effective porosity were used in the one-layer conceptual Model A, whereas uniform individual hydraulic properties were assigned to each layer in the multi-layer Model B. The vertical anisotropy in layers 1 and 3 of conceptual Model B was set at 1.0, with horizontal hydraulic conductivity being equivalent to vertical hydraulic conductivity. The vertical conductivity of layer 2 was one order of magnitude larger than the horizontal hydraulic conductivity of layer 2 and is consistent with air permeability data in Cunningham and others (2004a). The hydraulic conductivity was 32,808 feet per day (ft/d) (10,000 meters per day $(\mathrm{m} / \mathrm{d})), 328 \mathrm{ft} / \mathrm{d}(100 \mathrm{~m} / \mathrm{d})$, and 32,808 ft/d (10,000 m/d) in model layers 1, 2, and 3, respectively. An equivalent bulk hydraulic conductivity of $16,309 \mathrm{ft} / \mathrm{d}(4,971 \mathrm{~m} / \mathrm{d})$ was used in conceptual Model A and was calculated from the values of conductivities and thicknesses of the layers in conceptual Model B using a thickness-weighted average. The effective porosity for layers 1, 2, and 3 of conceptual Model B were set to $0.5,0.176$, and 0.5 , respectively, to represent high-porosity flow zones in layers 1 and 3 . The bulk equivalent effective porosity for conceptual Model A was calculated by multiplying the porosity of layers 1 and 3, which is assumed to dominate the flow, by the fraction of the thickness of the aquifer for which the groundwater flow zones compose, yielding an effective porosity of 0.246.

Recharge and evapotranspiration were not applied in either model. In both models, a well was placed in a cell in the center of the model domain and assigned a specified flux in the MODFLOW-2005 WEL package based on the maximum design-capacity pumping rate of the NWWF (225 million gallons 
per day $(\mathrm{Mgal} / \mathrm{d}))$. In the multi-layer conceptual Model B, the well was placed in the lowest highconductivity flow zone (layer 3).

Particles were tracked backwards from the simulated well for 500 days, effectively delineating the 500-day travel-time capture zone. Particles were placed around the well in layer 3 of Model B, with particles distributed at evenly spaced vertical intervals throughout the layer. Particles in Model A were distributed at evenly spaced vertical intervals in the bottom third of the single model layer to remain consistent with the locations of particles in Model B. Results of backward-tracked particles are shown in figure 1-1. Particle pathlines and head contours are similar for both conceptual models indicating the single-layer deterministic model of the Biscayne aquifer yields capture zones and drawdown comparable to those generated by a multi-layer model with explicit representation of flow zones. The parameter values used in Models A and B were representative of the Biscayne aquifer, however, considerable uncertainty exists for these parameters and deterministic results do not consider parameter uncertainty.

To further evaluate the validity of the one-layer regional model, the stochastic approach used to address the effects of parameter uncertainty in the regional-model study was also applied to conceptual Models A and B. Horizontal hydraulic conductivity fields were generated using the sequential Gaussian simulation (SGSIM) method in the utility FIELDGEN (Doherty, 2010) to create stochastic fields using an exponential variogram model. The correlation length of 13,123 $\mathrm{ft}(4,000 \mathrm{~m})$, the same as that used in the regional model, was used to create the perturbed multiplier fields, although in this case (Model A) hydraulic conductivity fields, and not multiplier fields, were created. A log-based sill of 0.1 and a mean value of $6,647 \mathrm{ft} / \mathrm{d}(2,026 \mathrm{~m} / \mathrm{d})$ were used to generate the stochastic hydraulic conductivity fields evaluated with conceptual Models A and B (these parameters are the same as those used in the regional model). Unlike the regional model, however, the stochastic hydraulic conductivity fields in the models presented herein were not conditioned using APT point data, as these models are conceptual. The generated hydraulic conductivity realizations were used, along with the values of effective porosity from the regional model, to create 10,000 versions of Model A that were statistically similar to the fields evaluated with the regional model.

For Model B, calculations were made to create horizontal hydraulic conductivity realizations for layers 1, 2, and 3 from the horizontal hydraulic conductivity realizations used in Model A. The bulk horizontal hydraulic conductivity used in Model A was assumed to be the thickness-weighted horizontal hydraulic conductivity of the individual layers of Model B. It was assumed that the horizontal hydraulic conductivity of the flow-zone layers 1 and 3 were equal $\left(K_{1}=K_{3}\right)$ and that the horizontal hydraulic conductivity of layer 2 was two orders of magnitude smaller than in layers 1 and $3\left(100^{*} K_{2}=K_{1}=K_{3}\right)$. Model B layers 1 and 3 are isotropic and the vertical hydraulic conductivity of model layer 2 is an order of magnitude greater than the horizontal hydraulic conductivity.

Effective porosity values used in the regional model were applied with spatial uniformity in Model A runs. Based on field observations (Cunningham and other, 2004a, b, 2006a, b, 2009; Renken and others, 2008; Shapiro et al, 2008; Harvey and others, 2008), flow zones in the study area (layers 1 and 3) may rapidly move groundwater and potential contaminants. Therefore, the effective porosity of the flow zones were calculated, using their thicknesses, from the effective porosity values used in the one-layer Model A runs. It was assumed that the effective porosities of layer 1 and layer 3 were equal because they are both flow zones. The effective porosity of matrix layer 2 was set at 0.176 . The following equation was solved for $n_{e_{B, 3, r}}$ (which is equivalent to $n_{e_{B, 1, r}}$ ) for each realization: 


$$
n_{e_{A, 1, r}}=\frac{n_{e_{B, 3, r}}\left(b_{B, 1}+b_{B, 3}\right)}{\sum_{l=1,2,3} b_{B, l}}
$$

where

$n_{e_{K, l, r}}$

is the effective porosity of layer $l$ in realization $r$ of Model $K$, and $b_{K, l}$ is the thickness of layer $l$ in Model $K$, where $K$ is either $A$ or $B$.

In the Monte Carlo simulations, Models A and B were further modified to include two canals, which were simulated using the MODFLOW River (RIV) Package. The locations of these two canals were the same in Models A and B, except in Model B the canals are located only in layer 1. The stages, conductances and bottom altitudes of the canals were modeled to resemble the L-30 Canal (to the west of the NWWF) and the canal directly to the north of the NWWF. The stage of the western canal was set at $3.12 \mathrm{ft}(0.95 \mathrm{~m})$ and the stage of the northern canal was set at $1.31 \mathrm{ft}(0.40 \mathrm{~m})$ based on data collected during dry conditions on June 19, 2004. The locations and shapes of the canals were meant to mimic the general location and shape of these canals with respect to the well fields, not the actual shape of the canals themselves. These canals in the regional model effectively enclose the well field (along with other connecting canals) whereas in the conceptual models simulated herein, the canals are implemented to investigate and compare the hydraulic effects of strong and weak canals, in general, in both a one layer and multi-layer context, on capture zones and drawdowns of the well field. The modified version of MODFLOW-2005, which uses the horizontal hydraulic conductivity of the cell to compute the RIV conductance, was used in Model A and B simulations; this allowed canal conductances to be varied stochastically as well. The weak sink option was used in MODPATH 5.0 to allow particles to track backwards through RIV cells that were not strong sources of water.

Lakes were not added to Models A and B Monte Carlo simulations because the lakes range in depth from 60 to $80 \mathrm{ft}$. As a result, the lakes would fully penetrate all model layers in Models A and B and would not result in any noticeable difference in the results.

Constant heads (fig. 1-2) were imposed at the left and right boundaries to allow an ambient flow field similar to that present in the regional model during dry conditions on June 19, 2004. The western boundary head was set at $2.95 \mathrm{ft}(0.9 \mathrm{~m})$ and the eastern boundary head was set at $0.98 \mathrm{ft}(0.3 \mathrm{~m})$. For Model B runs, the constant heads were set only in layer 1.

The wells (fig. 1-2) were placed in a line of 6 cells and the $80 \mathrm{Mgal} / \mathrm{d}$ pumpage was distributed evenly between these cells to reflect the configurations of the actual well fields of the NWWF and WWF. The wells in the Model B runs were placed in layer 3. Particles were placed around the wells in layer 1 in Model A runs and around the wells in layer 3 in Model B runs. Particles were placed in 10 different vertical locations throughout layer 3 in the Model B runs. To ensure particle endpoints in Models A and B would be comparable to one another, particles were vertically spaced throughout the bottom 34 percent of the Model A runs, because this is equivalent to the depth of the layer 3 production zone in Model B runs. The particles were tracked backwards for 210 days to obtain the 210-day capture zone. 
Initially, a control run was completed without well-field withdrawals to obtain a distribution of starting heads with which to calculate drawdown. Next a run was completed with well-field withdrawals of $80 \mathrm{Mgal} / \mathrm{d}$.

After 210 days of backward tracking from the wells, the particle endpoints were statistically analyzed using the technique adopted from Varljen and Shafer (1991), described in this report. The median and 95-percent confidence intervals (CIs) for the 210-day capture zone and for 1-ft drawdown were calculated.

In some simulations for Model B, cells in layer 1 became dry. These simulations were excluded in both the Model A and Model B run results so that results could be compared between models in a consistent manner. Following the exclusion process, results from 7,662 runs were available for comparison. Results show that 1-ft drawdown and 210-day capture zones were comparable but slightly more extensive for 1-layer Model A than for 3-layer Model B (fig. 1-3 and fig. 1-4). Results from this investigation are consistent with findings of Sepulveda and Kuniansky (2010) in which it was determined that flow in the unconfined surficial aquifer system in Florida could be simulated reasonably well as a one-layer unit with calculated composite horizontal hydraulic conductivity based on a thickness-weighted arithmetic mean of multiple lithologic units.

Reilly and Pollock (1993) define the contributing area of a well as the surface area that contributes recharge to the well. This differs from a capture zone, which is defined by the volume of aquifer water that enters the well within a specified amount of time. Forward and backward tracking will not always yield the same contributing area and forward tracking is preferred for contributing area determination, while backward tracking is often used for delineation of capture zone (Barlow, 1997). Forward tracking with the simple model was accomplished with particles placed on the tops of cells for each cell in the area surrounding the wells and canals in the one-layer model (not shown). These forward-tracked particles all ended within the well cells and their pathlines were consistent with pathlines of backward-tracked particles from the wells. Particles to the west of the western canal and to the north of the northern canal moved past the canals to the wells. Thus, the test simulations indicate that with a weak sink option chosen with MODPATH, particles will move past boundary conditions such as canals towards the wells with the one-layer model. 


\section{Appendix 2. Modification of MODFLOW-2005 Code}

Conductances of canals simulated using the MODFLOW-2005 River (RIV) Package were stochastic parameters in this investigation and were unique and variable along each canal for each of the 10,000 realizations. MODFLOW-2005 was modified and recompiled to calculate canal conductance internally from the assigned horizontal hydraulic conductivity of the aquifer cell in which a canal is located (found in the Layer-Property Flow (LPF) Package in the model), and the assigned conductance value of each RIV cell, which was specified in the RIV Package. This conductance value was set for each realization and equal to $\mathrm{L}^{*} \mathrm{~W} / \mathrm{M}$ (see Equation 1).

Within the module GWF2RIV7.f, the subroutine GWF2RIV7FM was changed to calculate CRIV from HK (from the LPF Package) and RIVR (from the RIV Package): SUBROUTINE GWF2RIV7FM(IGRID)

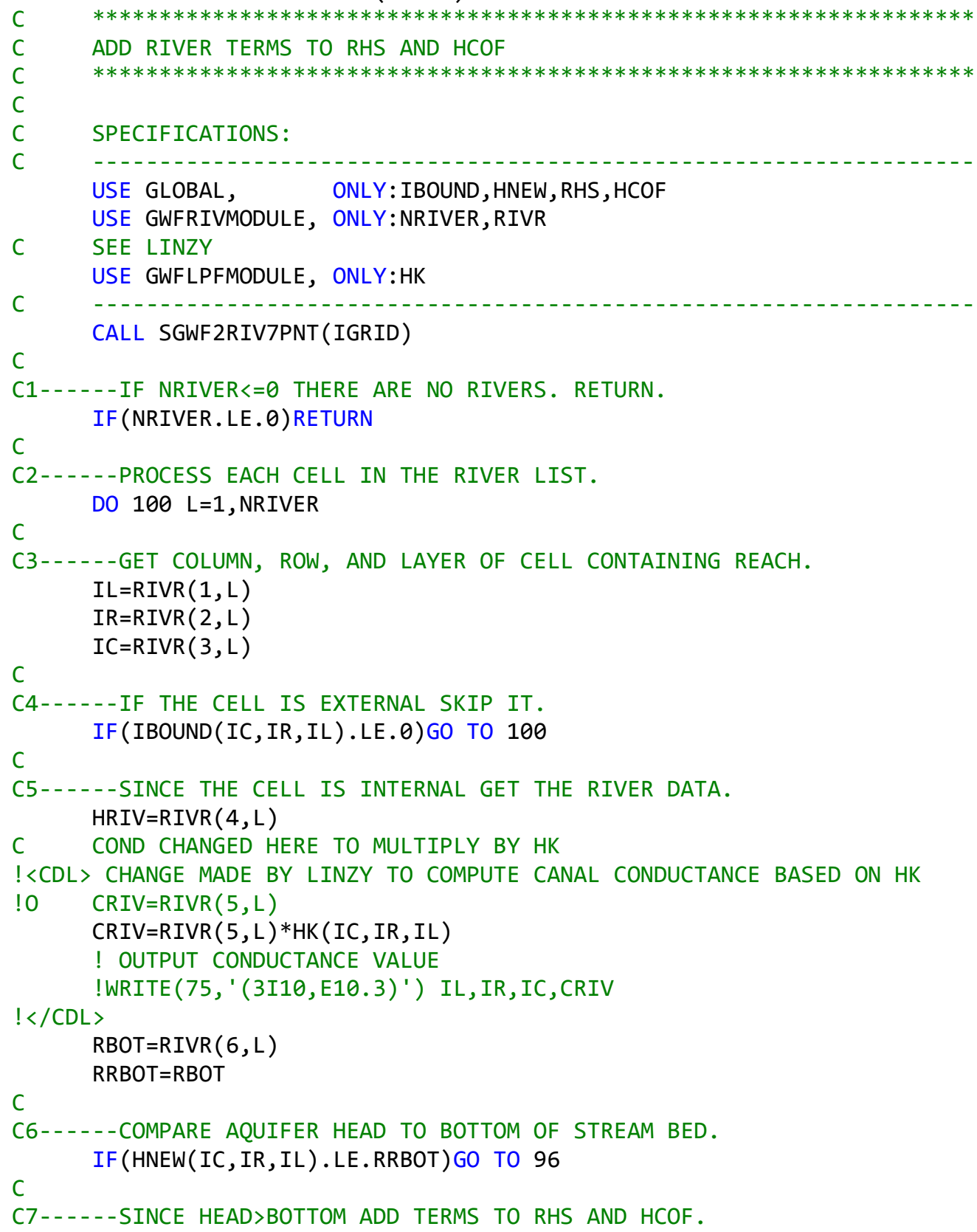




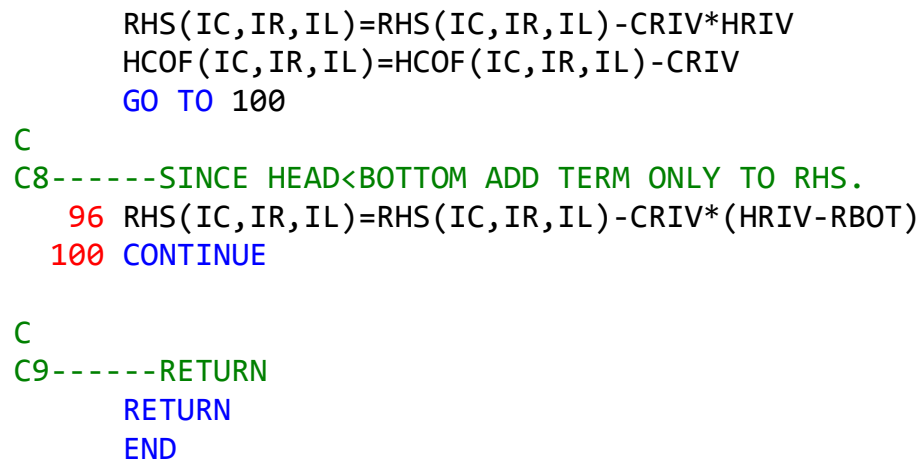

Also, the subroutine GWF2RIV7BD is changed to output the calculated CRIV to a file fort.75: SUBROUTINE GWF2RIV7BD(KSTP, KPER, IGRID)

$\mathrm{C} \quad * * * * * * * * * * * * * * * * * * * * * * * * * * * * * * * * * * * * * * *$

C CALCULATE VOLUMETRIC BUDGET FOR RIVERS

$\mathrm{C} \quad * * * * * * * * * * * * * * * * * * * * * * * * * * * * * * * * * * * * * * * * * * * * * * * * * * * * * * * * * * * * * * * * * * *$

C

C SPECIFICATIONS:

$\mathrm{C}$

USE GLOBAL, ONLY: IOUT, NCOL, NROW, NLAY, IBOUND, HNEW, BUFF

USE GWFBASMODULE, ONLY:MSUM, ICBCFL, IAUXSV, DELT, PERTIM, TOTIM, 1 VBVL, VBNM

USE GWFRIVMODULE, ONLY:NRIVER, IRIVCB, RIVR, NRIVVL, RIVAUX

C SEE LINZY

USE GWFLPFMODULE, ONLY:HK

C

DOUBLE PRECISION HHNEW, CHRIV, RRBOT, CCRIV, RATIN, RATOUT, RRATE

CHARACTER*16 TEXT

DATA TEXT /' RIVER LEAKAGE'/

C

CALL SGWF2RIV7PNT(IGRID)

C

C1-----INITIALIZE CELL-BY-CELL FLOW TERM FLAG (IBD) AND

C1-----ACCUMULATORS (RATIN AND RATOUT).

ZERO $=0$.

RATIN $=Z E R O$

RATOUT $=$ ZERO

$\mathrm{IBD}=0$

IF (IRIVCB. LT. 0 .AND. ICBCFL.NE.0) IBD $=-1$

IF (IRIVCB.GT.0) IBD $=$ ICBCFL

IBDLBL $=0$

C

C2-----IF CELL-BY-CELL FLOWS WILL BE SAVED AS A LIST, WRITE HEADER. IF (IBD.EQ. 2) THEN

NAUX=NRIVVL -7

IF (IAUXSV.EQ.0) NAUX $=0$

CALL UBDSV4(KSTP, KPER, TEXT, NAUX, RIVAUX, IRIVCB, NCOL, NROW, NLAY, 1 NRIVER, IOUT, DELT, PERTIM, TOTIM, IBOUND)

END IF

$\mathrm{C}$

C3-----CLEAR THE BUFFER.

DO $50 \quad I L=1$, NLAY

DO $50 \quad I R=1$, NROW

DO $50 I C=1, N C O L$

$\operatorname{BUFF}(I C, I R, I L)=Z E R O$ 


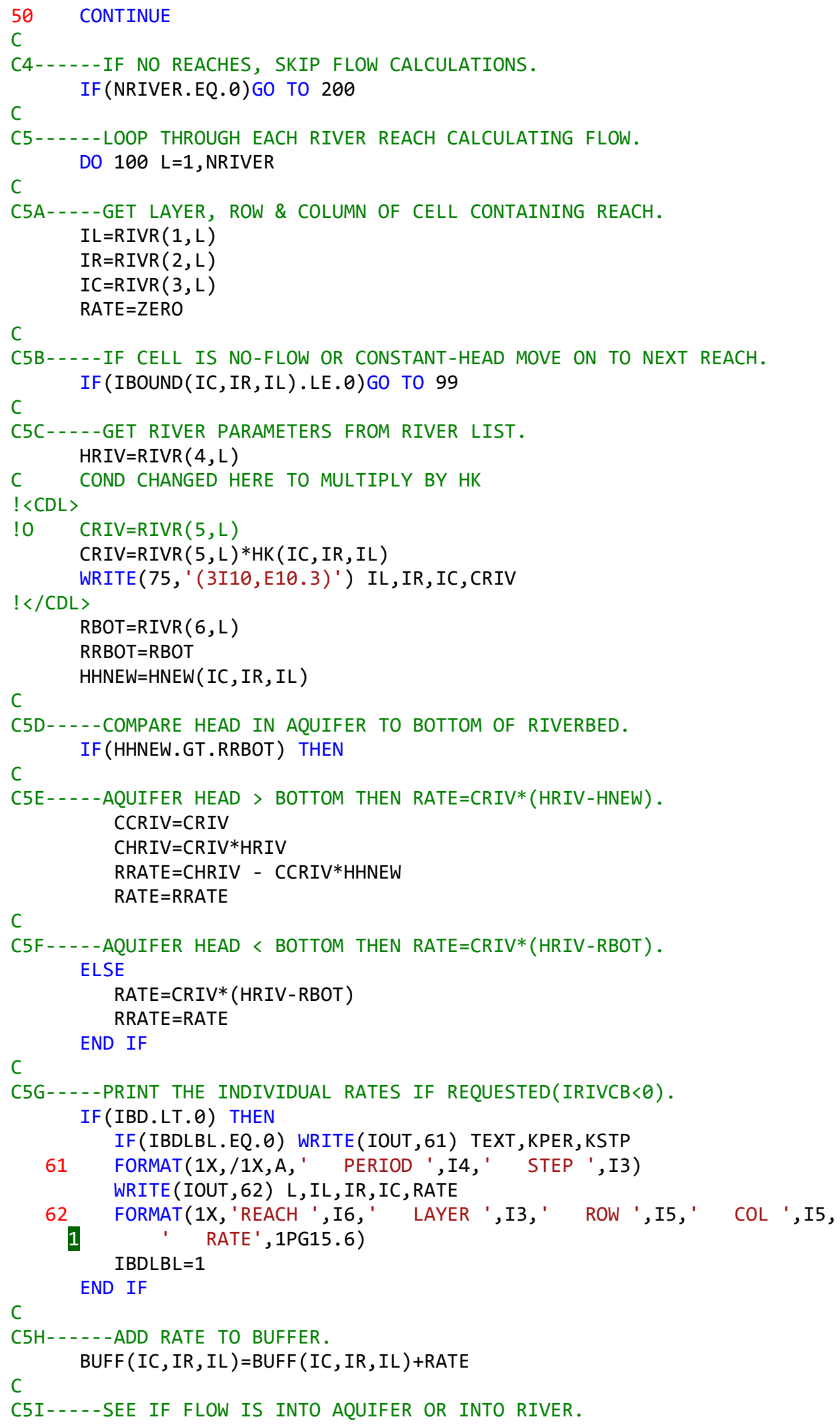




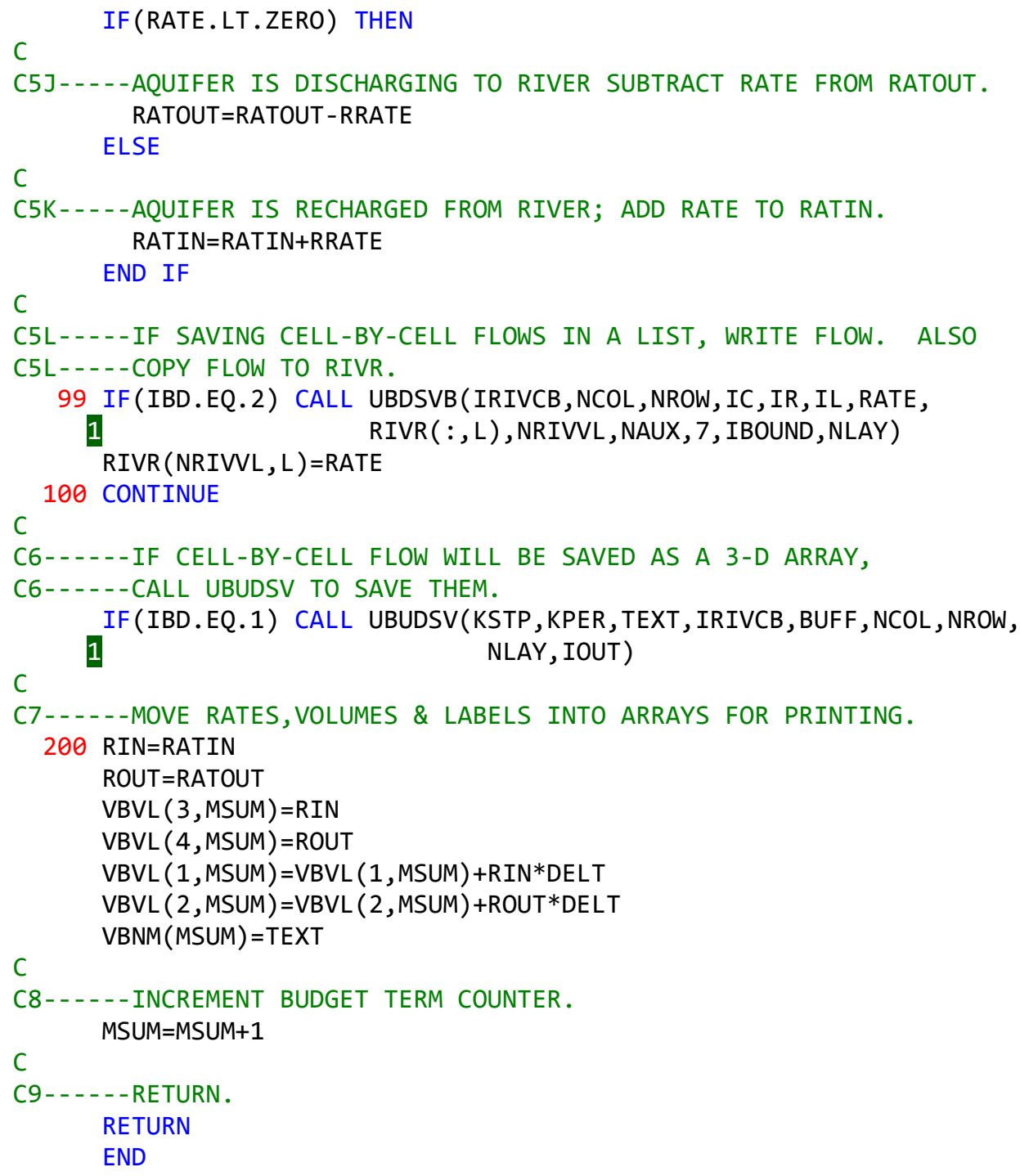




\section{Appendix 3. Test of Boundary Condition near the NWWF}

The western boundary canals are hydraulically connected to the Biscayne aquifer and control the stage near the well fields. The aquifer does extend west of the L-30 and L-31 Canals, however, and underflow has been documented. A simple test with the base-case, steady-state, average condition was made to check that the western canal does indeed control the head near the NWWF, and that simulated water levels near the well field would be identical if another boundary condition was applied. The test was accomplished by making the aquifer system active west of the L-30 Canal. Additionally, a general head boundary (GHB) was set at the western edge of the model using the average head at two gages for December 19, 2002, the day chosen to represent average hydrologic conditions for the steady-state model (Station "USGS 254754080344300 SHARK RIVER SLOUGH NO.1 IN CONS.3B NR COOPERTOWN" with daily stage of $7.74 \mathrm{ft}$ and Station "USGS 255250080335001 SITE $71 \mathrm{IN}$ CONSERVATION AREA 3B NR COOPERTOWN, FL" with daily stage of $8.07 \mathrm{ft}$, which averages to $7.91 \mathrm{ft} \mathrm{NGVD29).} \mathrm{December} \mathrm{is} \mathrm{at} \mathrm{the} \mathrm{end} \mathrm{of} \mathrm{the} \mathrm{wet} \mathrm{season} \mathrm{and} \mathrm{much} \mathrm{of} \mathrm{the} \mathrm{area} \mathrm{west} \mathrm{of} \mathrm{L-30} \mathrm{Canal} \mathrm{is}$ inundated with water. Stage in the L-30 Canal is $4.79 \mathrm{ft}(1.46 \mathrm{~m})$, thus there is an eastward gradient in the Biscayne aquifer from the conservation area and the Everglades. Two tests were conducted with the general-head conductance set at 269 square feet per day $\left(\mathrm{ft}^{2} / \mathrm{d}\right)\left(25\right.$ square meters per day $\left.\left(\mathrm{m}^{2} / \mathrm{d}\right)\right)($ cell area 26,910 square feet $\left(\mathrm{ft}^{2}\right)\left(2500\right.$ square meters $\left.\left(\mathrm{m}^{2}\right)\right)$ multiplied by a vertical hydraulic conductivity $\left(\mathrm{K}_{\mathrm{v}}\right)$ of $0.0328 \mathrm{ft} / \mathrm{d}(0.01 \mathrm{~m} / \mathrm{d})$ and a $3.28 \mathrm{ft}(1 \mathrm{~m})$ thickness of sediment $)$ and $26,910 \mathrm{ft}^{2} / \mathrm{d}\left(2500 \mathrm{~m}^{2} / \mathrm{d}\right)$ (cell area $26,910 \mathrm{ft}^{2}\left(2500 \mathrm{~m}^{2}\right)$ multiplied by a $\mathrm{K}_{\mathrm{v}}$ of $3.28 \mathrm{ft} / \mathrm{d}(1 \mathrm{~m} / \mathrm{d})$ and a $3.28 \mathrm{ft}(1 \mathrm{~m})$ thickness of sediment). Water-level contours remain the same near the NWWF (fig. 3-1). The change in conductance of the GHB only affects water levels between the levee and the western extent of the new active area.

The test in Appendix 1 indicated that particles can move beneath a canal when the weak sink option is used in MODPATH. The boundary condition tests in this appendix indicate that the L-30 Canal provides a strong hydraulic head boundary condition and pathlines from the canals to the well fields are the same if the area west of the L-30 Canal is actively simulated or not actively simulated. The area west of the L-30 Canal is not urban and the goal of the study was to estimate capture zones within urban areas for a maximum of 210 days of particle travel. In order to save on computation times, this area was made inactive and thus the simulations cannot be used to determine which parts of the natural wetlands are in the overall contributing area of the NWWF. 


\section{Appendix 4. Comparative analysis of lake representation using high hydraulic conductivity zones and the LAK Package}

In groundwater models, lakes are commonly represented by cells with high hydraulic conductivity (Lee, 1996; Anderson and others, 2002; Hunt and others, 2003). The use of high hydraulic conductivity cells as an approach to represent lakes was compared to the explicit representation of lakes using the MODFLOW Lake (LAK) Package (Merritt and Konikow, 2000) to support the approach taken for this investigation.

When the LAK Package is used, model cells delineated as lake cells are excluded from groundwater flow calculations and the relation between stage, volume, and surface area for individual lakes are determined directly from the model layer geometry. Individual lakes can be defined as single grid cells or contiguous groups of grid cells. Aquifer-lake exchanges are a function of the difference between the simulated lake stage and simulated head in active groundwater cells immediately adjacent (horizontally and vertically) to the defined lake perimeter. Lake conductances are calculated as the harmonic mean of lake sediment and aquifer hydraulic properties. The LAK Package includes functionality to simulate lakes with varying lateral extents, as well as coalescing lakes; available options, functionality, and numerical implementation of the LAK Package are detailed in Merritt and Konikow (2000).

Some of the advantages of using the LAK Package are (1) the ability to simulate a single stage for a lake, (2) the ability to easily calculate lake water budgets, and (3) the elimination of model convergence issues related to use of high hydraulic conductivities to represent lakes. The most substantial limitations of the LAK Package for this investigation are (1) the difficulty of achieving steady-state lake stages when initial lake stages and groundwater levels differ substantially from steadystate conditions and lake volumes are large, and (2) the termination of MODPATH 5.0 (Pollock, 1994) particles in lake cells, which limits the ability to determine well-field capture zones.

A one-layer steady-state MODFLOW model was developed using parameters representative of the Biscayne aquifer in northwestern Miami-Dade County to evaluate the appropriateness of the high hydraulic conductivity approach to represent lakes surrounding the NWWF (fig. 4-1). A total of 38 separate quarry lakes were simulated. The model domain comprised 300 columns and rows, with a constant horizontal grid spacing of $164 \mathrm{ft}(50 \mathrm{~m})$. Uniform upper and lower model altitudes of $9.84 \mathrm{ft}(3$ m) and -88.6 ft (-27 m) NAVD 88, respectively, were specified and resulted in an aquifer thickness of approximately $100 \mathrm{ft}$. A hydraulic conductivity of 7,136 ft/d (2,175 m/d) was assigned to all active model cells in both models. For the high hydraulic conductivity simulation, a hydraulic conductivity of $7.136 \times 10^{5} \mathrm{ft} / \mathrm{d}\left(2.175 \times 10^{5} \mathrm{~m} / \mathrm{d}\right)$ was assigned to the lake cells.

A constant head of $9.51 \mathrm{ft}(2.90 \mathrm{~m})$ and $6.92 \mathrm{ft}(2.11 \mathrm{~m})$ was assigned to the left and right boundaries, respectively, in both models. A no-flow boundary was assigned to the top and bottom boundaries in both models; recharge was not applied in either model. A maximum evapotranspiration rate of $32.5 \mathrm{in} / \mathrm{yr}$ was applied to active groundwater and lake cells in both models. An evapotranspiration extinction depth of $3.28 \mathrm{ft}(1 \mathrm{~m})$ was applied in all active groundwater cells. An evapotranspiration surface altitude of $9.84 \mathrm{ft}(3 \mathrm{~m})$ was applied in cells representing the aquifer and an evaporation surface altitude of $-65.62 \mathrm{ft}(-20 \mathrm{~m})$ was applied to quarry lakes represented using the high hydraulic conductivity approach. Fifteen production wells, each having a constant individual groundwater withdrawal rate of $15 \mathrm{Mgal} / \mathrm{d}$ for a total well-field withdrawal rate of $225 \mathrm{Mgal} / \mathrm{d}$, were simulated in both models. Canals were not simulated in either model. For the LAK Package model, a lake-bed leakance value of $2.175 \times 10^{5}$ feet per day per foot $((\mathrm{ft} / \mathrm{d}) / \mathrm{ft})$ was assigned to each lake cell and is based on a sediment hydraulic conductivity of $7,136 \mathrm{ft} / \mathrm{d}(2,175 \mathrm{~m} / \mathrm{d})$ and a sediment thickness of 
$0.328 \mathrm{ft}(0.1 \mathrm{~m})$. Backward-tracked particle pathlines from the 15 production wells were calculated using MODPATH 5.0 (Pollock, 1994) for both models. For the LAK Package simulation, particle locations on the upgradient side of lakes were determined for the simulations in which the lakes were represented with high hydraulic conductivity. These particle locations on the upgradient side of lakes were used to define additional starting particle locations for the LAK Package simulations, and the resulting pathlines were directly compared with particle pathlines for the simulations representing lakes with high hydraulic conductivity throughout the model domain.

The geometric multigrid (GMG) solver (Wilson and Naff, 2004) was used in both models. Residual ( $\ell^{2}$-norm) and head convergence criteria of 1,766 cubic feet per day $\left(\mathrm{ft}^{3} / \mathrm{d}\right)(50$ cubic meters per day $\left.\left(\mathrm{m}^{3} / \mathrm{d}\right)\right)$ and $3.28 \times 10^{-6} \mathrm{ft}\left(1 \times 10^{-6} \mathrm{~m}\right)$ were used to ensure that lake stages and volumes were not changing in the LAK Package model. A head convergence criterion greater than $3.28 \times 10^{-6} \mathrm{ft}(1 \times$ $10^{-6} \mathrm{~m}$ ) resulted in lake levels that would change if final groundwater heads and lake levels from one simulation were used as initial conditions for a second simulation. In all cases, the final $\ell^{2}$-norm of the residual and maximum head change for both models was less than $272 \mathrm{ft}^{3} / \mathrm{d}\left(7.7 \mathrm{~m}^{3} / \mathrm{d}\right)$ and $3.28 \times 10^{-6} \mathrm{ft}$ $\left(1 \times 10^{-6} \mathrm{~m}\right)$, respectively.

Simulated steady-state groundwater heads and particle pathlines for the high hydraulic conductivity model and LAK Package model are shown in figure 4-1. Quantitative comparison of simulated groundwater inflows and outflows and evapotranspiration from the 38 defined quarry lakes are summarized in table 4-1. All lake water-budget flow terms simulated using the high hydraulic conductivity approach and the LAK Package differed by less than \pm 2.0 percent. Comparison of groundwater heads, particle pathlines, and quantitative lake water-budget terms indicates the high hydraulic conductivity approach for representing quarry lakes adjacent to the NWWF yields similar results to the approach in which lakes are explicitly represented using the LAK Package. Thus, the approach using high hydraulic conductivity cells for lakes, which is easier and introduces fewer parameters, was used for this investigation. 


\section{Appendix 5. Additional Groundwater Head Calibration Plots}

Figure 5-1. Daily observed and model-simulated water levels for monitoring wells in the study area not shown in figure 13.

Figure 5-1 is shown on page 0 (प.

\section{Appendix 6. Comparison with an Alternative Particle-Tracking Analysis Approach}

Chin and others (2010) proposed a method to estimate well field travel-time capture zones in areas characterized by lakes. The method uses an advective-dispersive backward particle-tracking algorithm that accommodates lake residence times to determine travel-time contours. Lake residence 
times of particles that traverse lakes are added to the time required for the particle to reach the lake from the pumping well in order to delineate the backward-tracked travel-time contour. If the sum of the lake residence time and travel time from the pumping well to the lake is greater than the travel-time contour of interest, then the entire lake should be included in the capture zone. Conversely, if the sum of the lake residence time and travel time from the pumping well to the lake is less than the capture zone of interest, the difference between the capture zone of interest and the sum is calculated, and particles are tracked backwards from the inflow side of the lake for this additional length of time.

This method is compared to an alternative method of tracking particles backwards through lakes with no residence-time adjustment (fig. 6-1). The particle tracks backwards to the lake in 24 days (fig. 6-1A). The particle continues to move through the lake and reaches the other side, where it exits, enters a second lake at 70 days, and exits that lake at 80 days to continue backward tracking. In contrast, figure 6-1 $B$ shows results with the residence-time post-processing adjustment to the particle times. This particle tracks backwards to the first lake, the residence time (10 days) is added to the travel time from the pumping well to the lake (24 days), and the particle location is adjusted to the exit point of the lake (actually the entry point because this is backward tracking), for a total travel time thus far of 34 days. By comparison, the particle in figure 6-1 $A$ does not exit the lake until 57 days of travel. The particle in figure 6-1B continues to track backwards for 13 more days, encountering the second lake, with a residence time of 5 days, where its location is adjusted to the exit point of the lake where the travel time is 52 days. By comparison, the particle location in figure 6-1A had a travel time of 80 days.

Chin and others (2010) illustrated this residence-time backward particle-tracking approach with an advective-dispersive code for particle tracking for the NWWF using a previously published multilayer calibrated model in which residence times for lakes near the pumping wells were estimated by dividing the volume of the lake by the steady-state outflow from the lake into groundwater (Chin and others, 2010). This calculation of residence time is based on the assumption that the lake is well-mixed.

To compare results of the model used in the current study with the results presented by Chin and others (2010), a modified version of the deterministic base-case simulation representing dry hydrologic conditions (June 19, 2004) was created. Parameters and details were changed in the dry hydrologic conditions steady-state model to better match details in the model of Chin and others (2010). The maximum pumping rate for the NWWF was changed to $158 \mathrm{Mgal} / \mathrm{d}$. Lakes were specified by Chin and others (2010) using a hydraulic conductivity of $1.00 \times 10^{6} \mathrm{ft} / \mathrm{d}(305,000 \mathrm{~m} / \mathrm{d})$, a value greater than that used in base-case and Monte Carlo simulations evaluated in the current study. Both hydraulic conductivities were tested and calculated residence times were not found to be sensitive to this parameter, likely because both values for lake conductivity are very large. The lakes highlighted in Chin and others (2010), namely, 22, 23, 28, 30, 32 and 33, were simulated for steady-state dry hydrologic conditions using the lake coverage of Chin instead of the 2004 lake coverage (fig. 6-2 and fig. 12). Residence times were estimated using lake outflow rates calculated from steady-state groundwater water-budget terms for individual lakes by multiplying the percentage of lake transmissivity to total cell transmissivity by the value for that cell in the cell-by-cell flow file. This scaling created an adjusted cellby-cell flow file. This adjusted cell-by-cell flow file, which is scaled to better represent flows from lakes into the groundwater as opposed to the total flow between cells, was input into ZONEBUDGET (Harbaugh, 1990) to calculate lake outflows into the groundwater for each lake. Lake volumes were calculated by multiplying lake cell areas and the depths of the lakes in each cell, which were estimated from bathymetric data and rock-mining permits (J. Baker, Miami-Dade Department of Permitting, Environment, and Regulatory Affairs, unpub. data, 2011). Where lake-bottom altitude data were unavailable, a depth of $60 \mathrm{ft}$ was assumed based on the majority of rock-mining permits for the Lake Belt region. 
A quantitative comparison between results of this investigation and Chin and others (2010) was made for the lakes shown in figure 6-2. Residence times for the model used in this investigation are mostly smaller than those calculated by Chin and others (2010) (table 6-1), likely because the lake volumes are generally smaller than those used by Chin and others (2010) (lake-bottom altitudes were not reported in Chin and others, 2010). Furthermore, flow rates from the lake into the aquifer were generally larger in this investigation (except for lakes 30 and 33) than those in Chin and others (2010), likely because dry conditions represented in this investigation differ from the conditions used in the model of Chin and others (2010). Smaller residence times indicate that particles will remain in the lakes in this investigation for a shorter duration than was calculated by Chin and others (2010). The one exception is lake 30, located southwest of the NWWF, for which the residence time calculated by the current model is approximately twice the value calculated by Chin and others (2010). Smaller residence times imply more particles will potentially need to be backward-tracked from the inflow side of the lake and potentially for a longer amount of time than those particles in the model of Chin and others (2010). This finding could lead to, in general, more spatially extensive capture zone estimates using the model in this investigation. The residence-time post-processing particle adjustment used in this investigation addresses the need to track particles backward beyond lake inflows to estimate capture zones, or to include the entire lake within the capture zone, depending on the duration of the capture zone and lake residence time, as recommended by Chin and others (2010). 



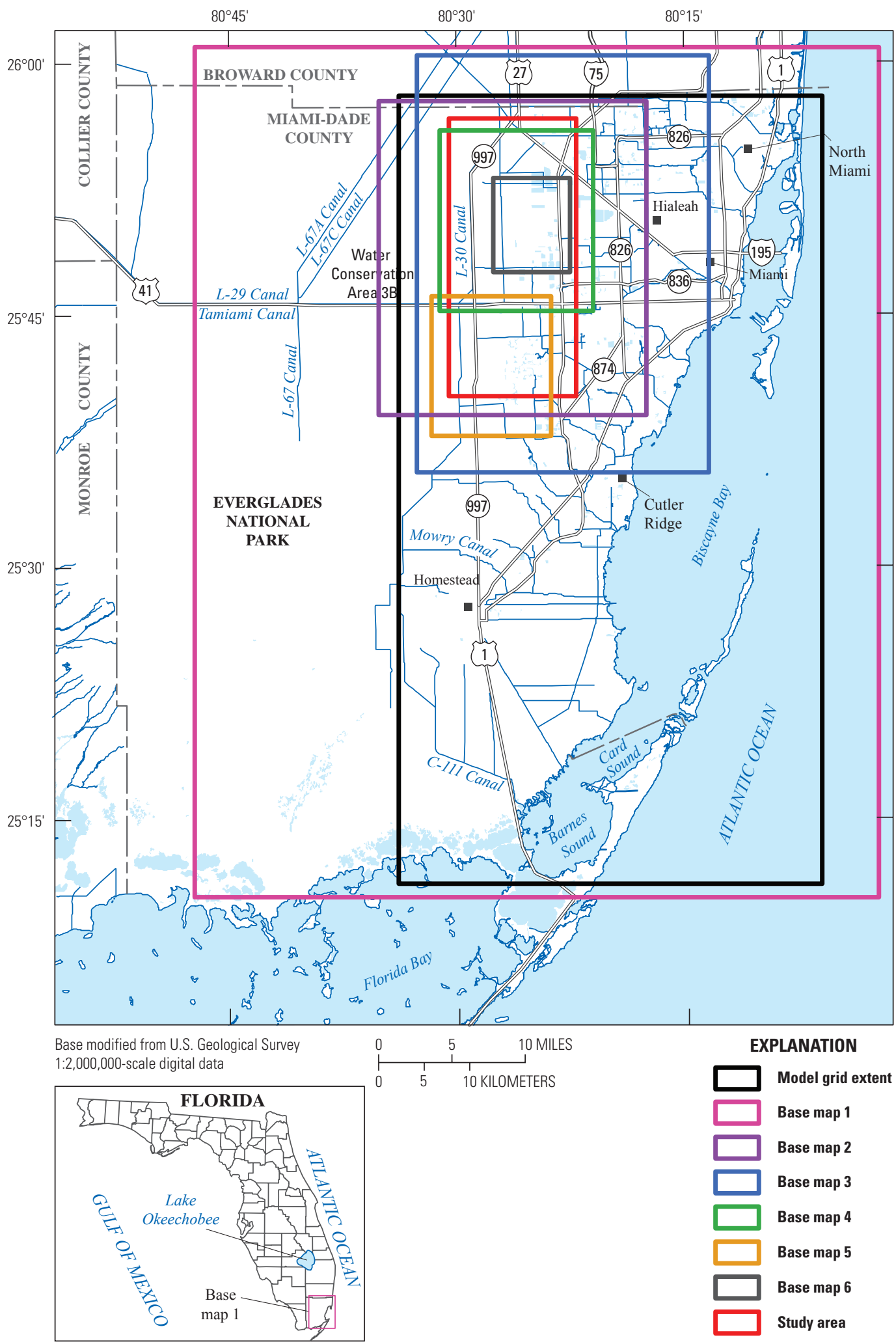

Figure 1. Locations of all base maps used throughout this report. Base maps are referred to in each map figure caption. 


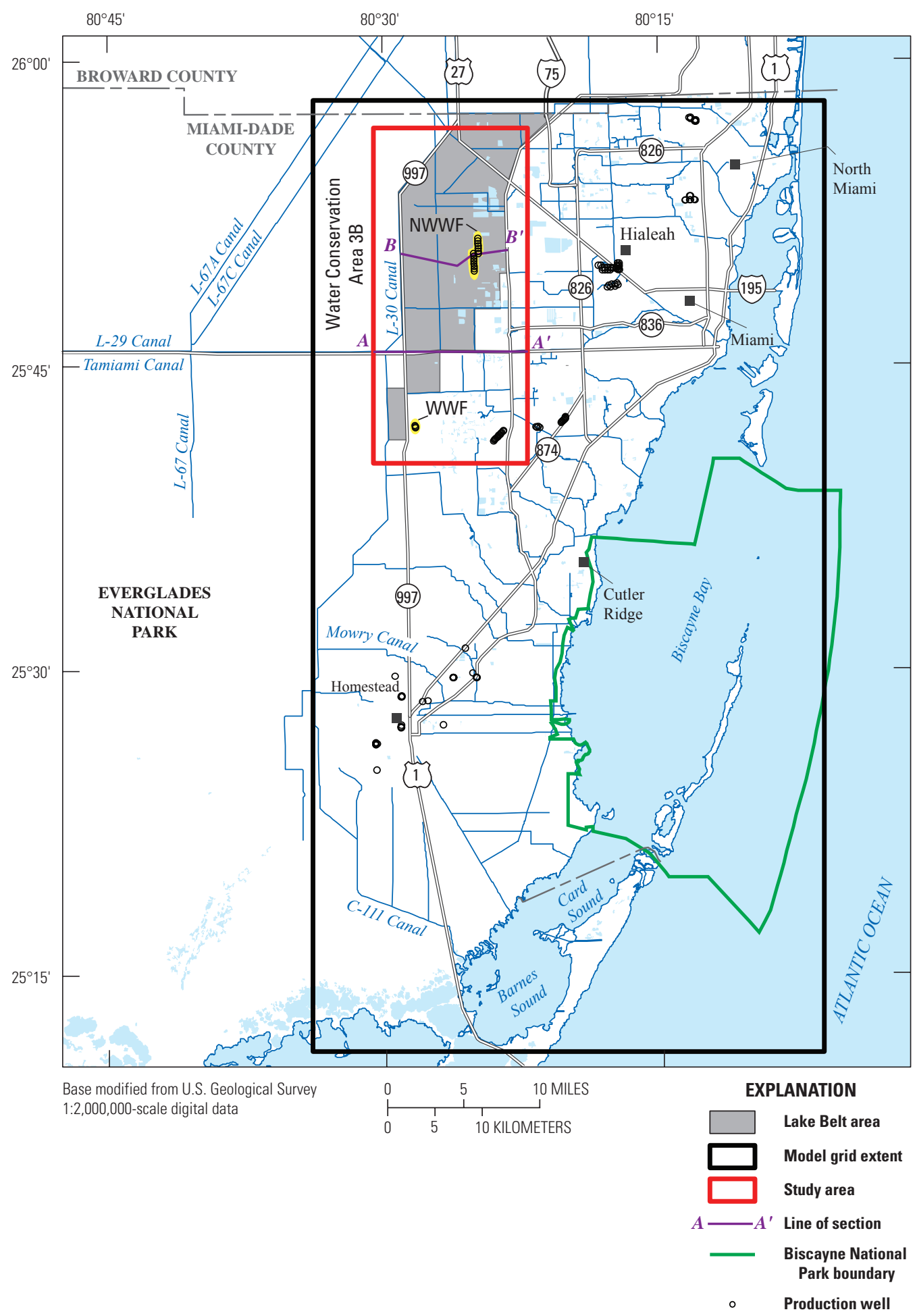

Figure 2. Model grid extent, study area, hydrogeologic sections $A-A^{\prime}$ and $B-B^{\prime}$, location of production well fields and location of canals, southeastern Florida. Area shown is Base map 1 (fig. 1). NWWF is Northwest Well Field. WWF is West Well Field. 


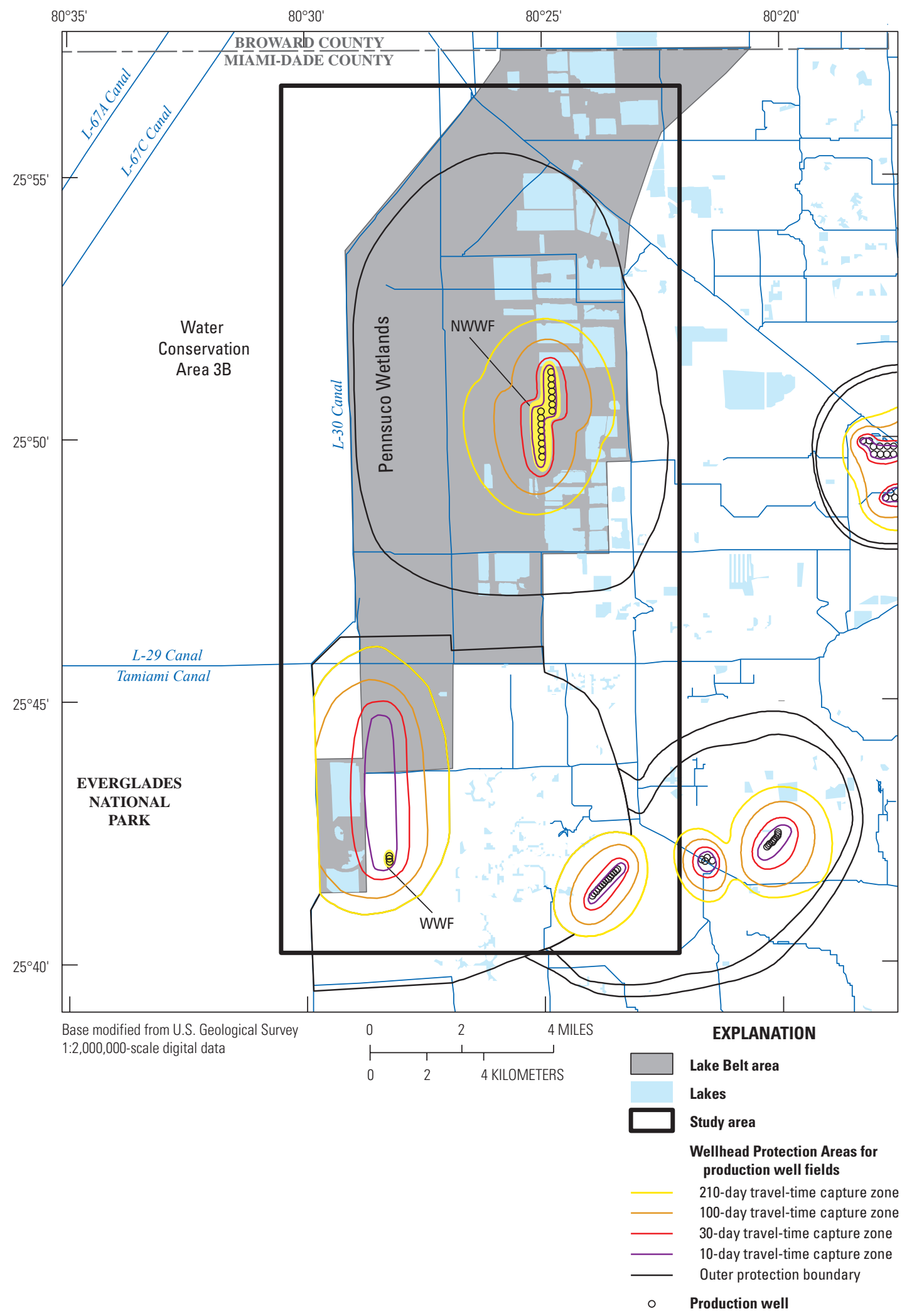

Figure 3. Study area and existing Wellhead Protection Areas for production well fields in Miami-Dade County (Miami-Dade County Department of Regulatory and Economic Resources,

http://www.miamidade.gov/derm/library/water/wellfield_protection_areas_poster.pdf, accessed

February 8, 2012). Area shown is Base map 2 (fig. 1). NWWF is Northwest Well Field. WWF is West Well Field. 


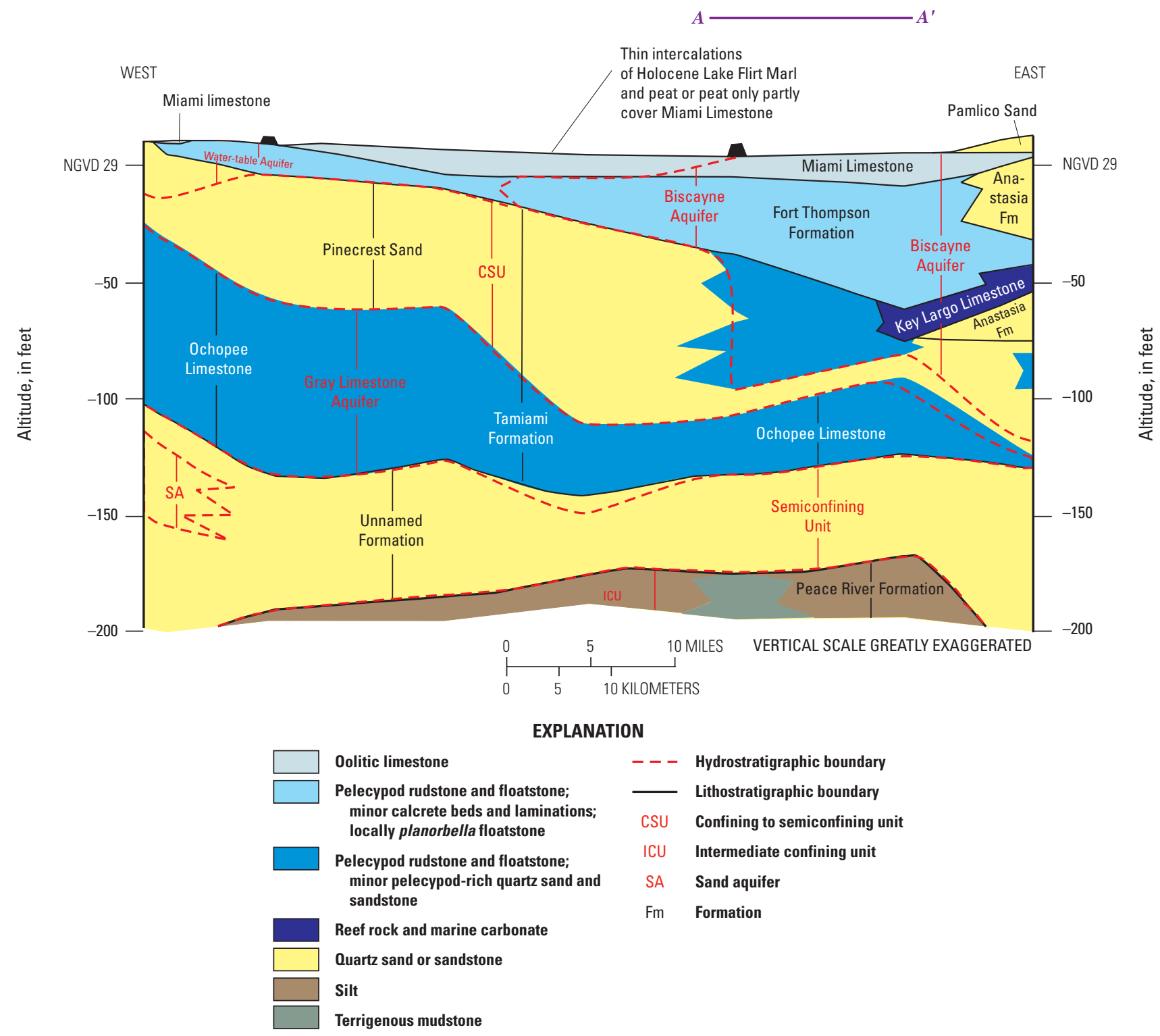

Figure 4. Hydrogeologic cross section with subset section $A-A^{\prime}$. Modified from Reese and Cunningham (2000). Location of subset cross section shown in fig. 2. 


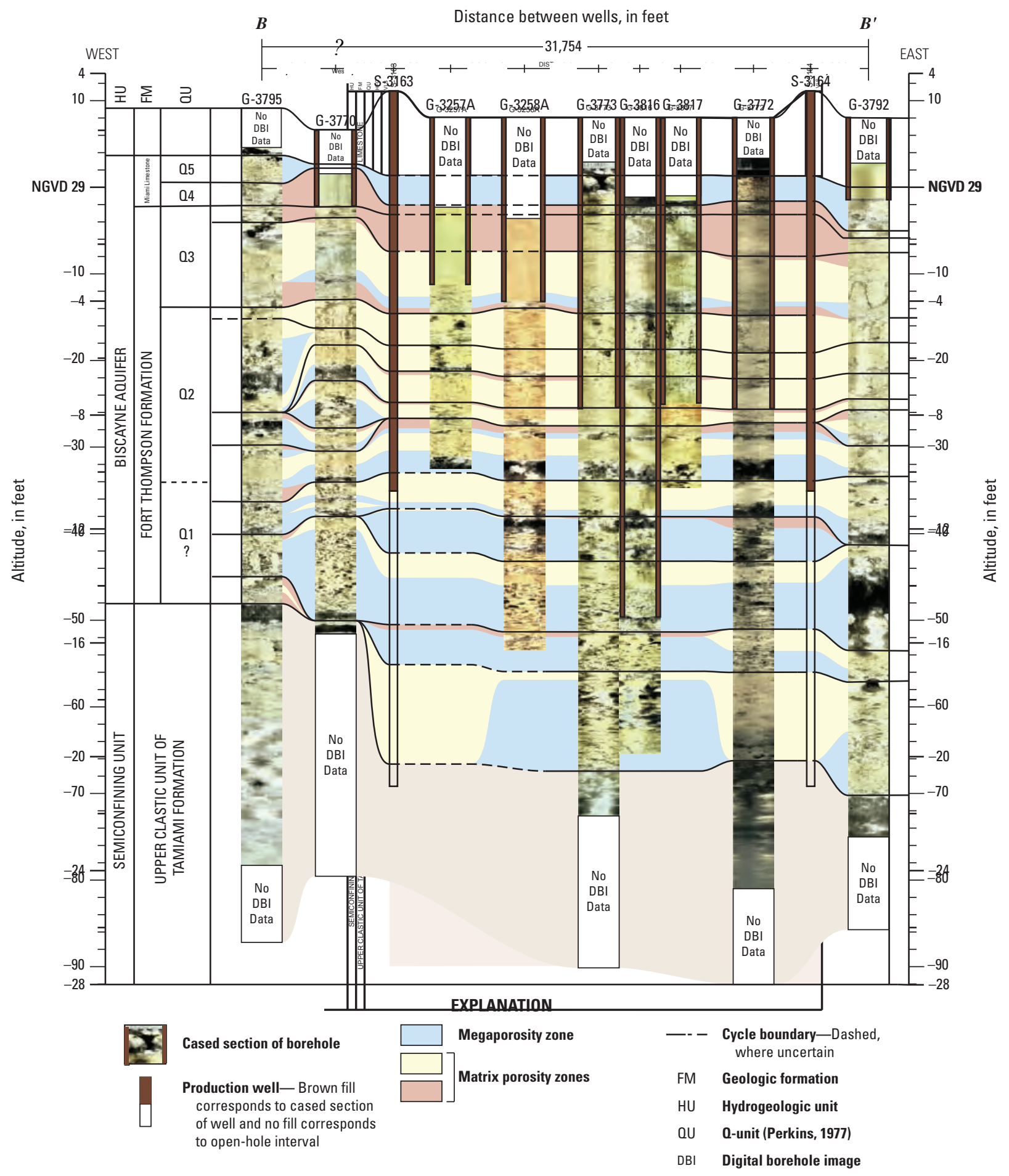

Figure 5. Hydrogeologic cross section $B-B^{\prime}$ across central part of the study area, including the Northwest Well Field (modified from Renken and others, 2008). Location of cross section shown in fig. 2. 


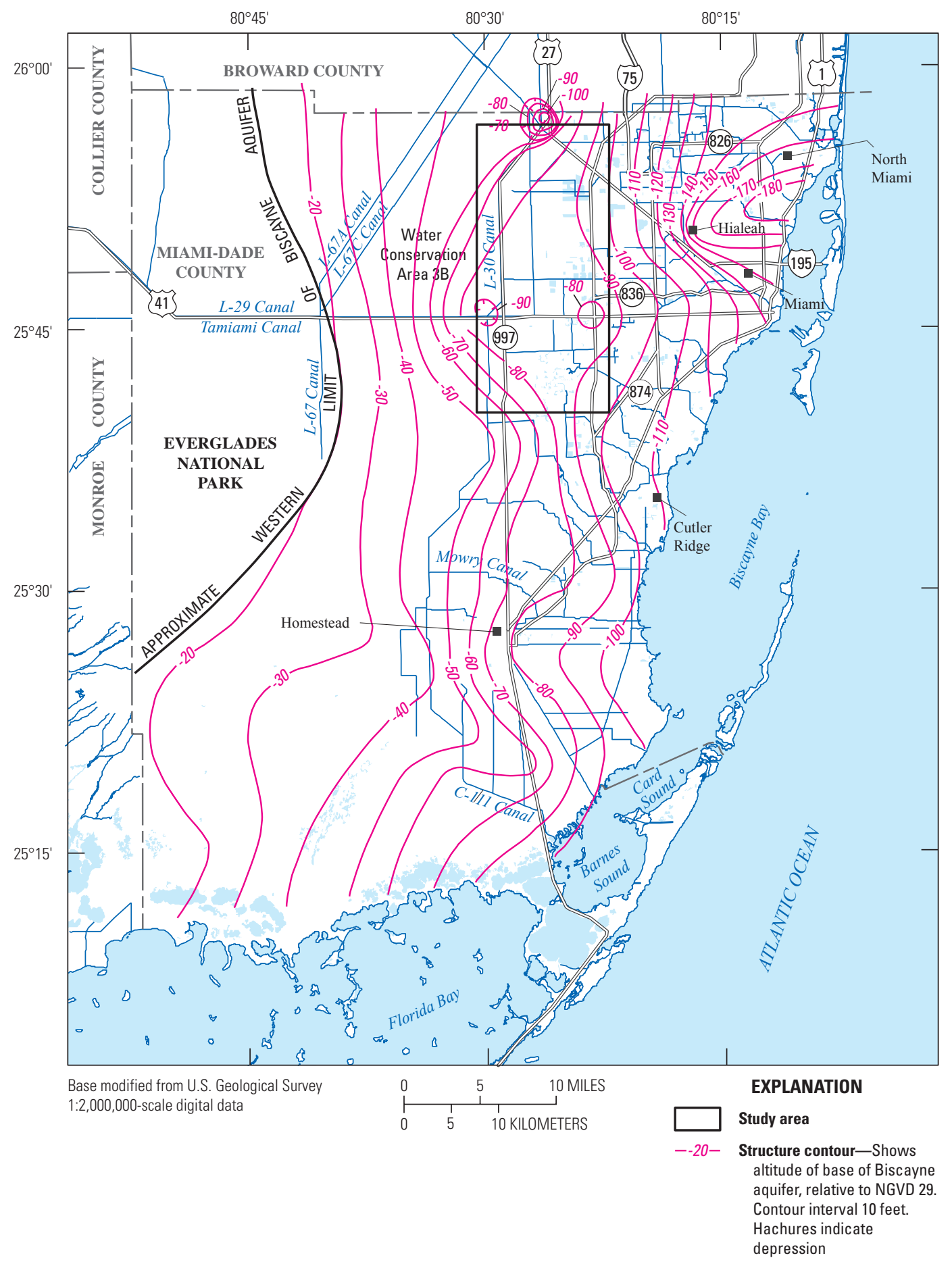

Figure 6. Altitude of the base of the Biscayne aquifer and its western extent throughout most of Miami-Dade County (Fish and Stewart, 1991). 


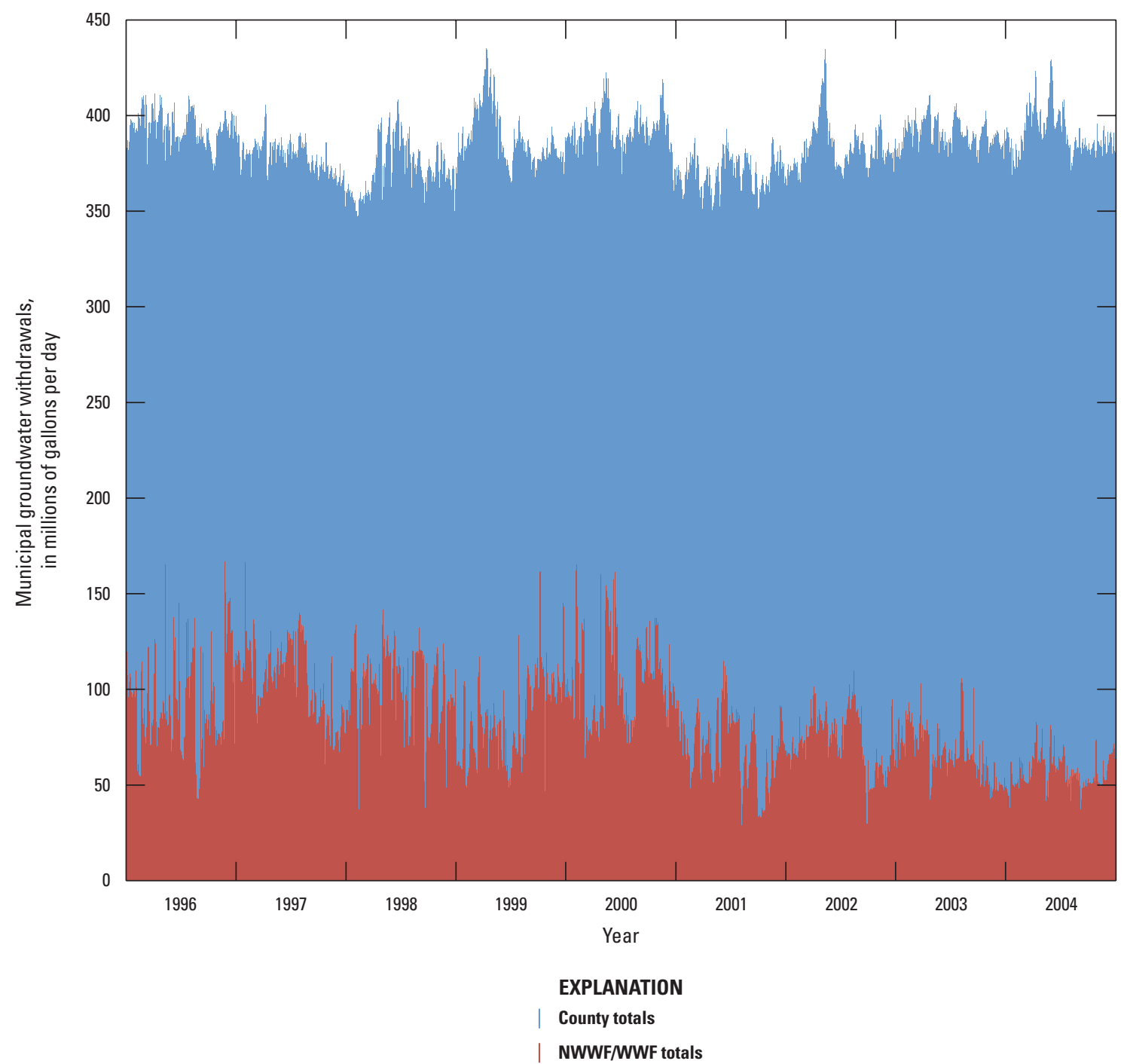

Figure 7. Daily municipal supply well withdrawals from the Biscayne aquifer in Miami-Dade County for January 1, 1996, through December 31, 2004. NWWF is Northwest Well Field. WWF is West Well Field. 


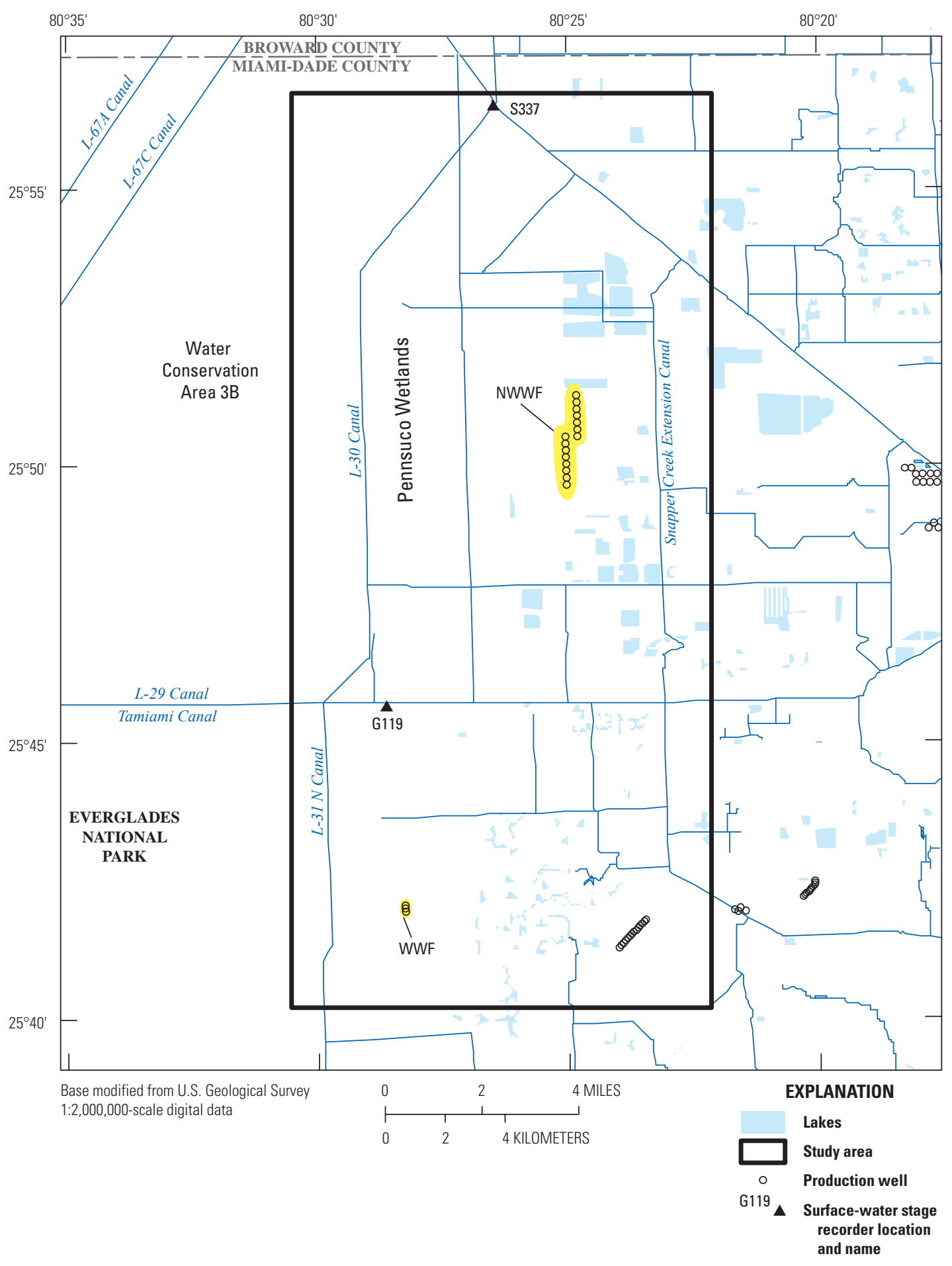

Figure 8. Primary and secondary canal system in study area. Area shown is Base map 2 (fig. 1). NWWF is Northwest Well Field. WWF is West Well Field. 


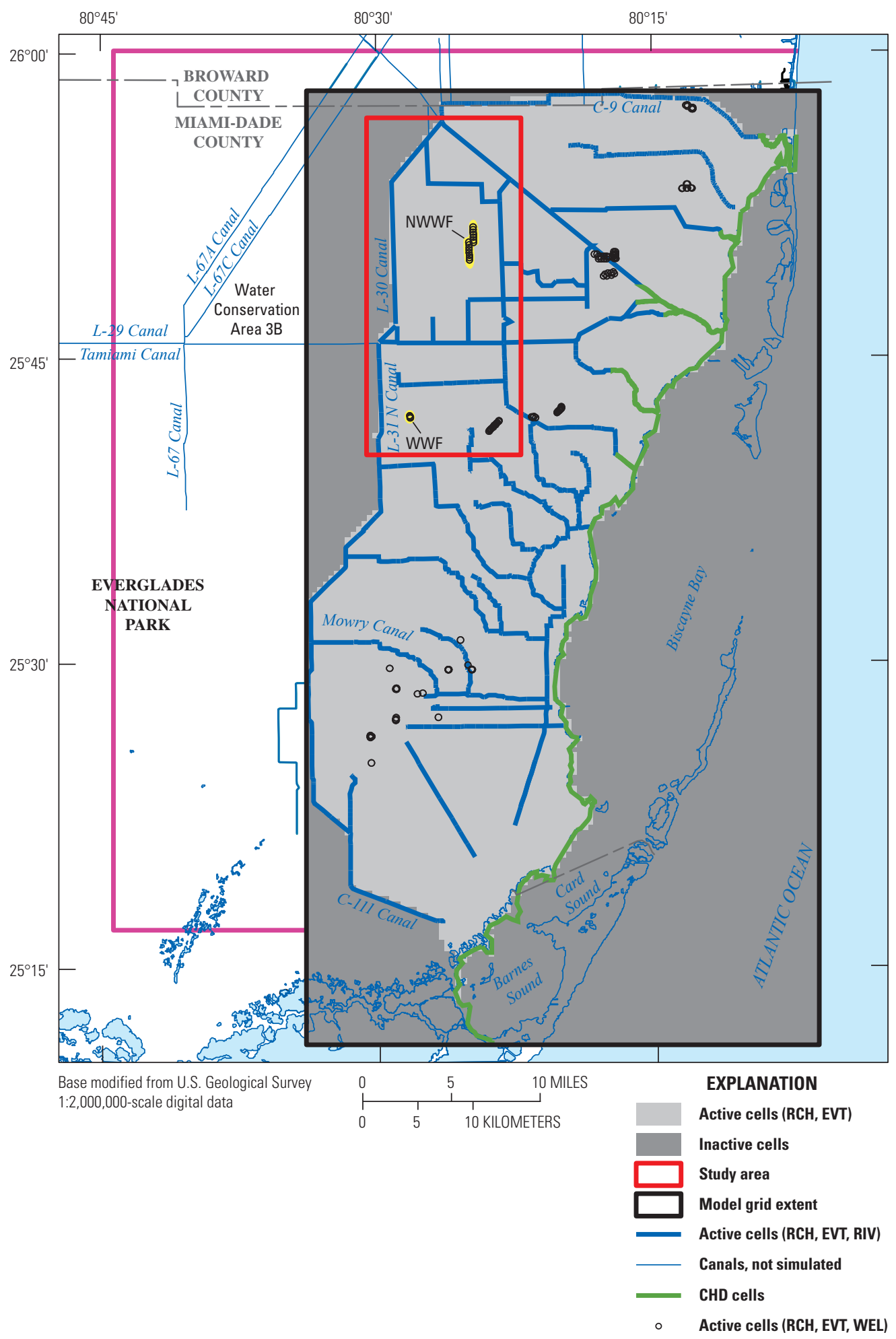

Figure 9. Location of active and inactive model cells, and type of MODFLOW boundary condition. $[\mathrm{RCH}=$ Recharge Package, EVT = Evapotranspiration Package, RIV = River Package, $\mathrm{CHD}=$ Time-Variant Specified-Head Package, and WEL = Well Package $]$. Area shown is Base map 1 (fig. 1). NWWF is Northwest Well Field. WWF is West Well Field. 


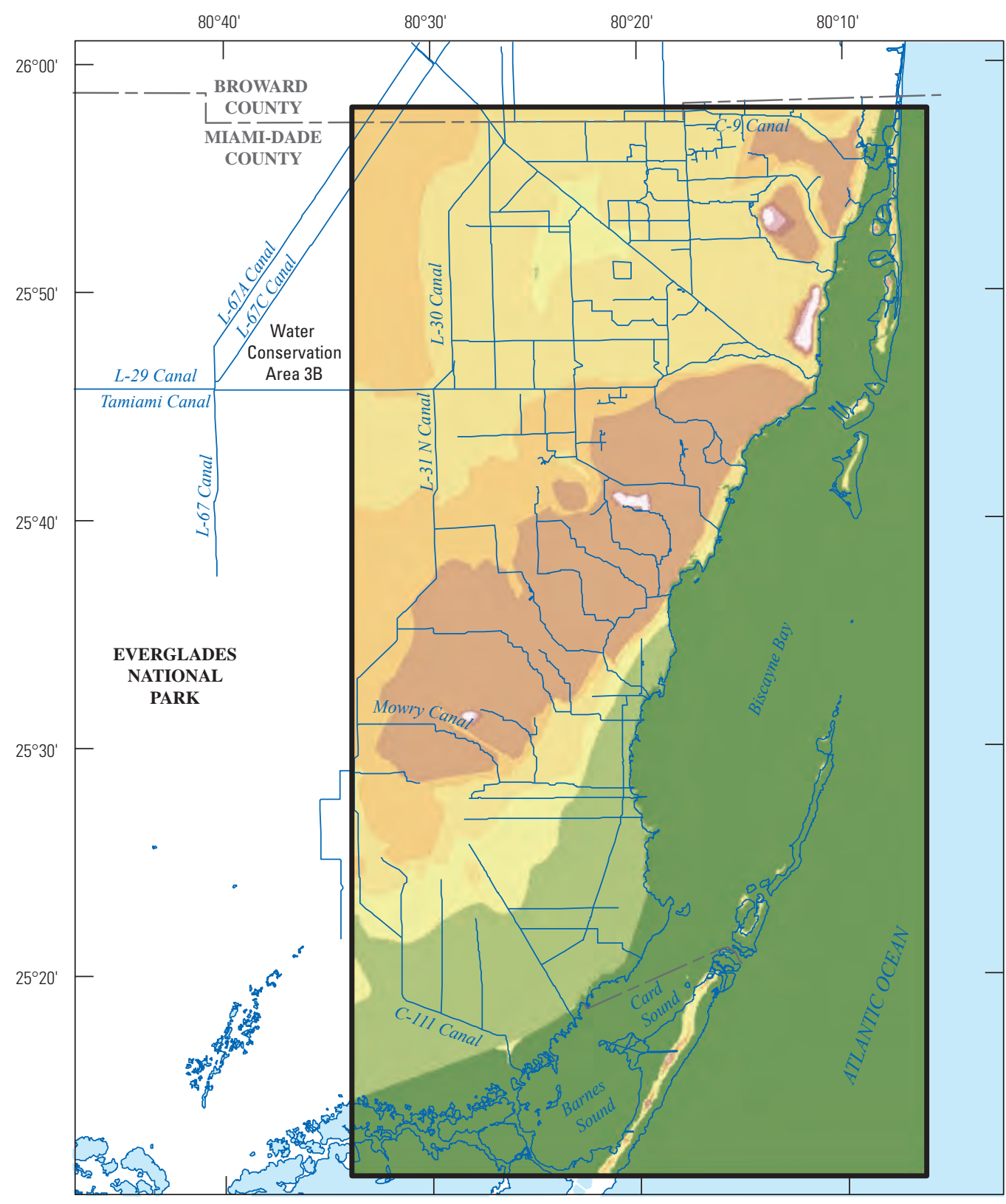

Base modified from U.S. Geological Survey $1: 2,000,000$-scale digital data

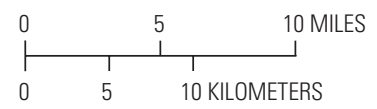

\section{EXPLANATION}

Land surface altitude, in feet NAVD 88

Less than 0

0 to 1.99

2 to 3.99

4 to 5.99

6 to 7.99

8 to 9.99

10 to 11.99

12 to 13.99

14 to 15.99

Model grid extent

Figure 10. Altitude of the top of the Biscayne aquifer model. Area shown is Base map 1 (fig. 1). 


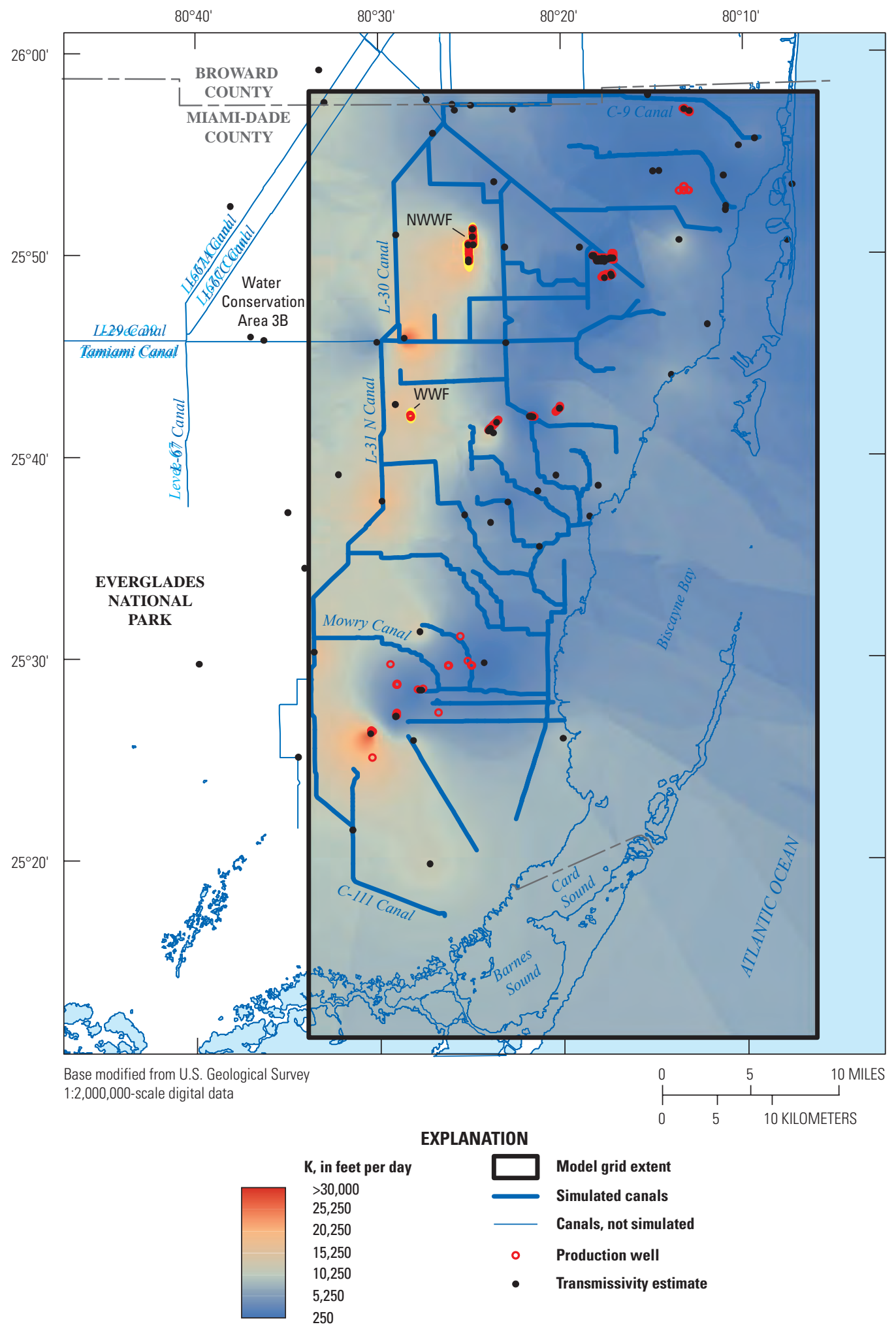

Figure 11. Hydraulic conductivity field for the base-case simulation and locations of transmissivity estimates derived from aquifer performance tests. Area shown is Base map 1 (fig. 1). 


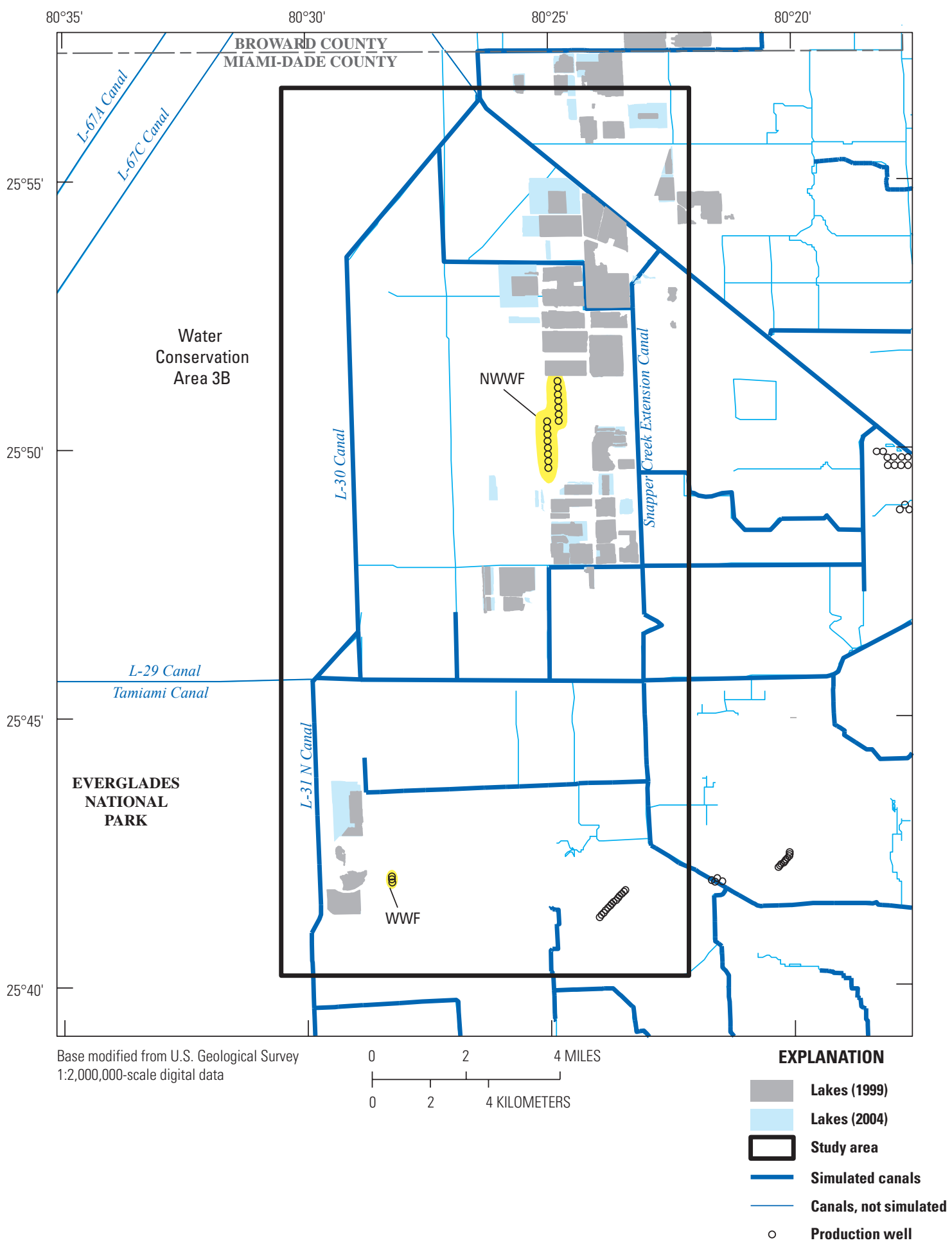

Figure 12. Locations of lakes in 1999 (transient simulation) and 2004 (steady-state simulations). Area shown is Base map 2 (fig. 1). NWWF is Northwest Well Field. WWF is West Well Field. 

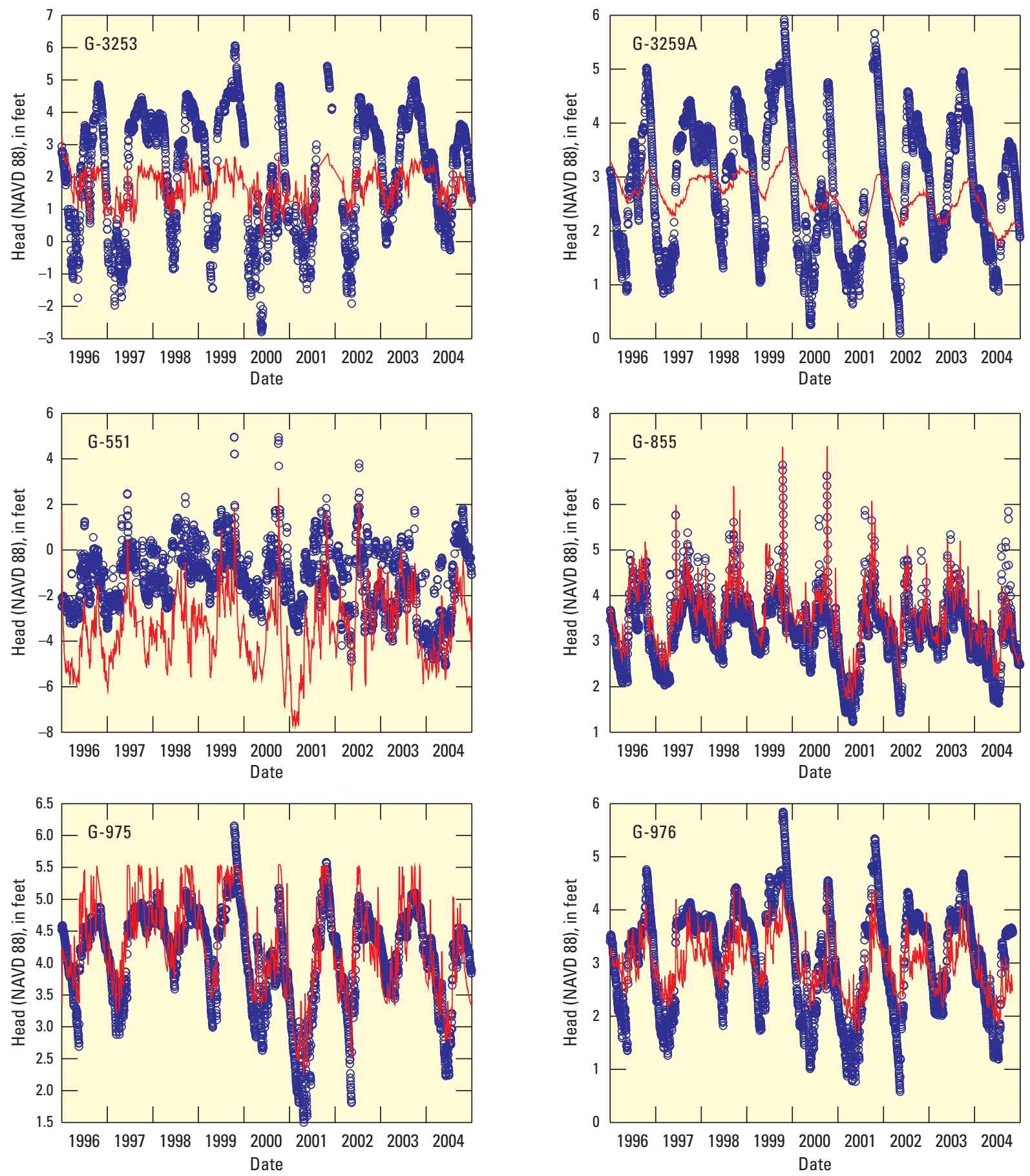

\section{EXPLANATION}

Simulated groundwater heads

Observed groundwater heads

Figure 13. Daily observed and model-simulated water levels for selected monitoring wells in the study area. 


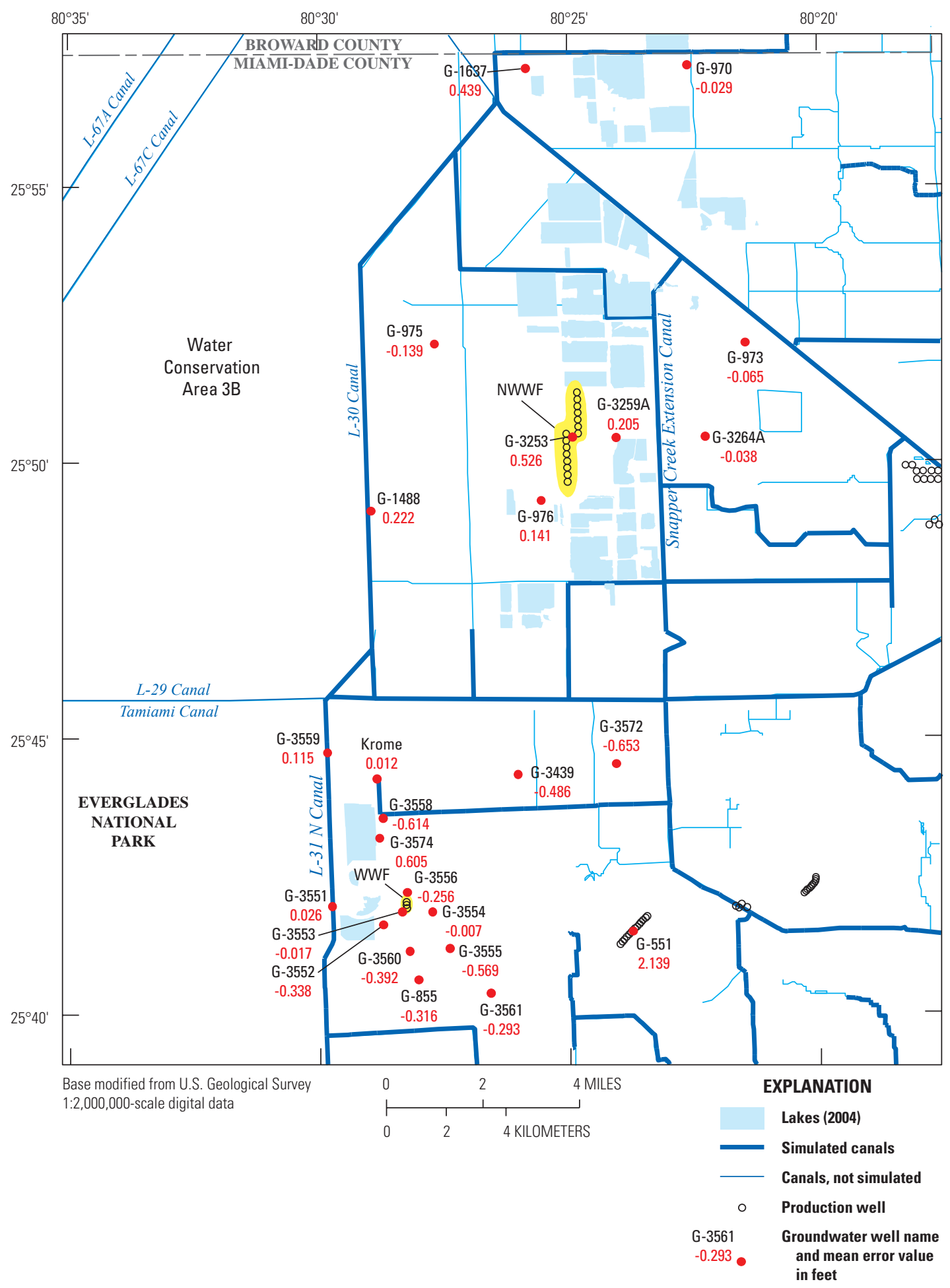

Figure 14. Locations of groundwater observation data used to calibrate model and mean error calculated from observed and simulated daily water levels. Area shown is Base map 2 (fig. 1). NWWF is Northwest Well Field. WWF is West Well Field. 


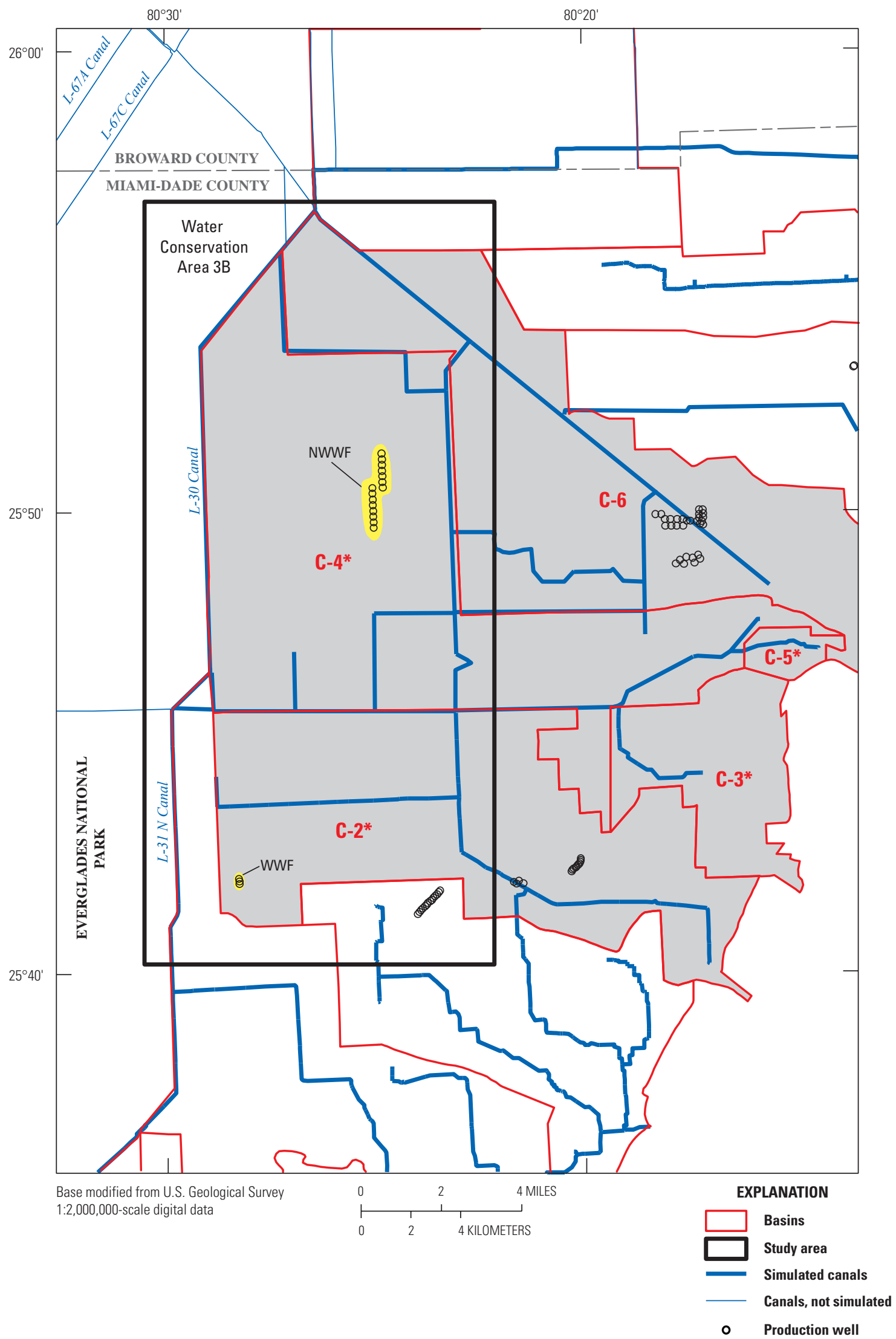

Figure 15. Selected surface-water basins (shaded) in simulated area, locations of production wells, and canals. Area shown is Base map 3 (fig. 1). NWWF is Northwest Well Field. WWF is West Well Field. 

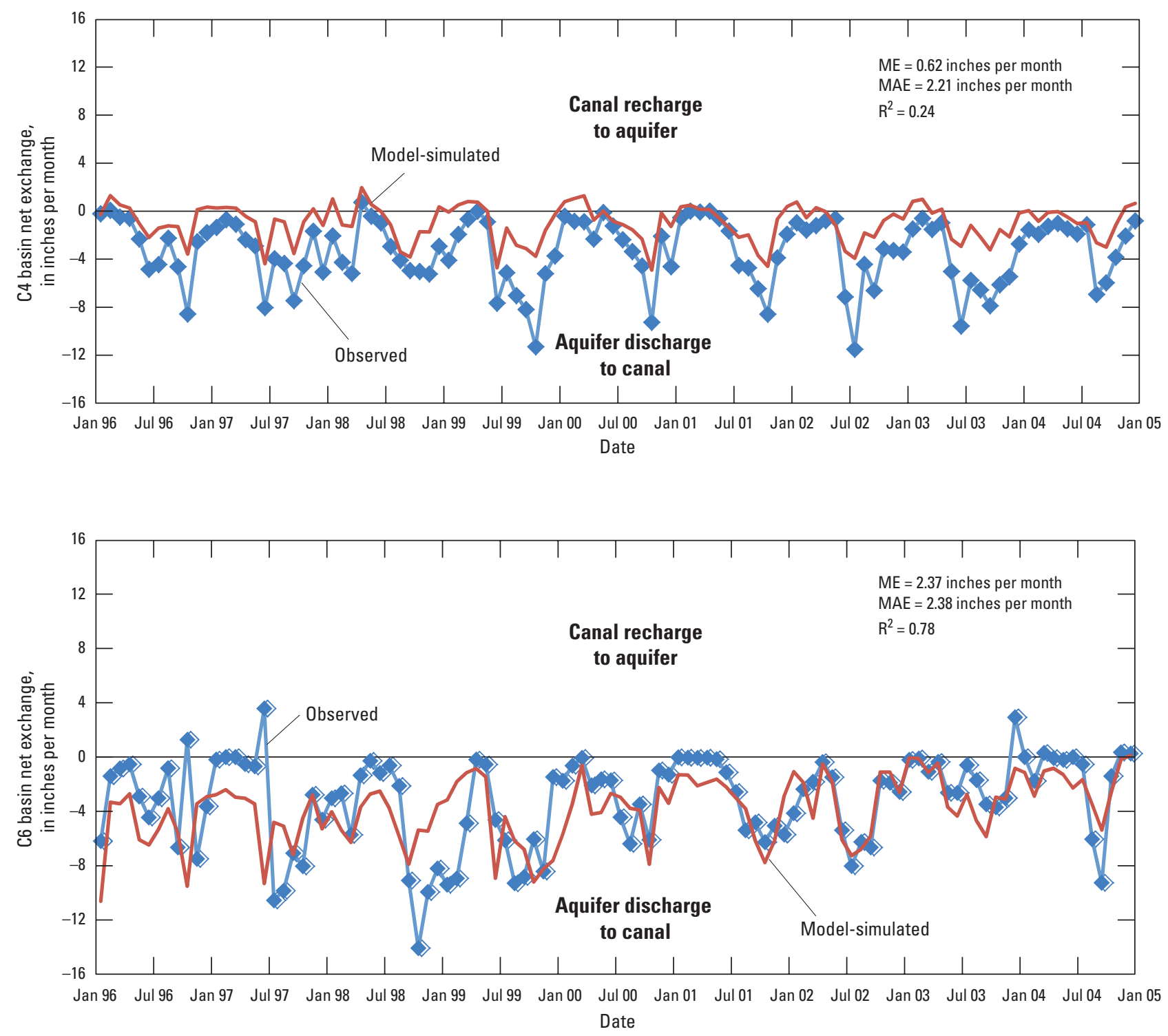

Figure 16. Monthly model-simulated (red) and observed (blue) net exchange for composite C-4 and C-6 basins, and mean error (ME), mean absolute error (MAE) and the coefficients of determination $\left(\mathrm{R}^{2}\right)$ for simulated versus observed net exchange for each basin. 


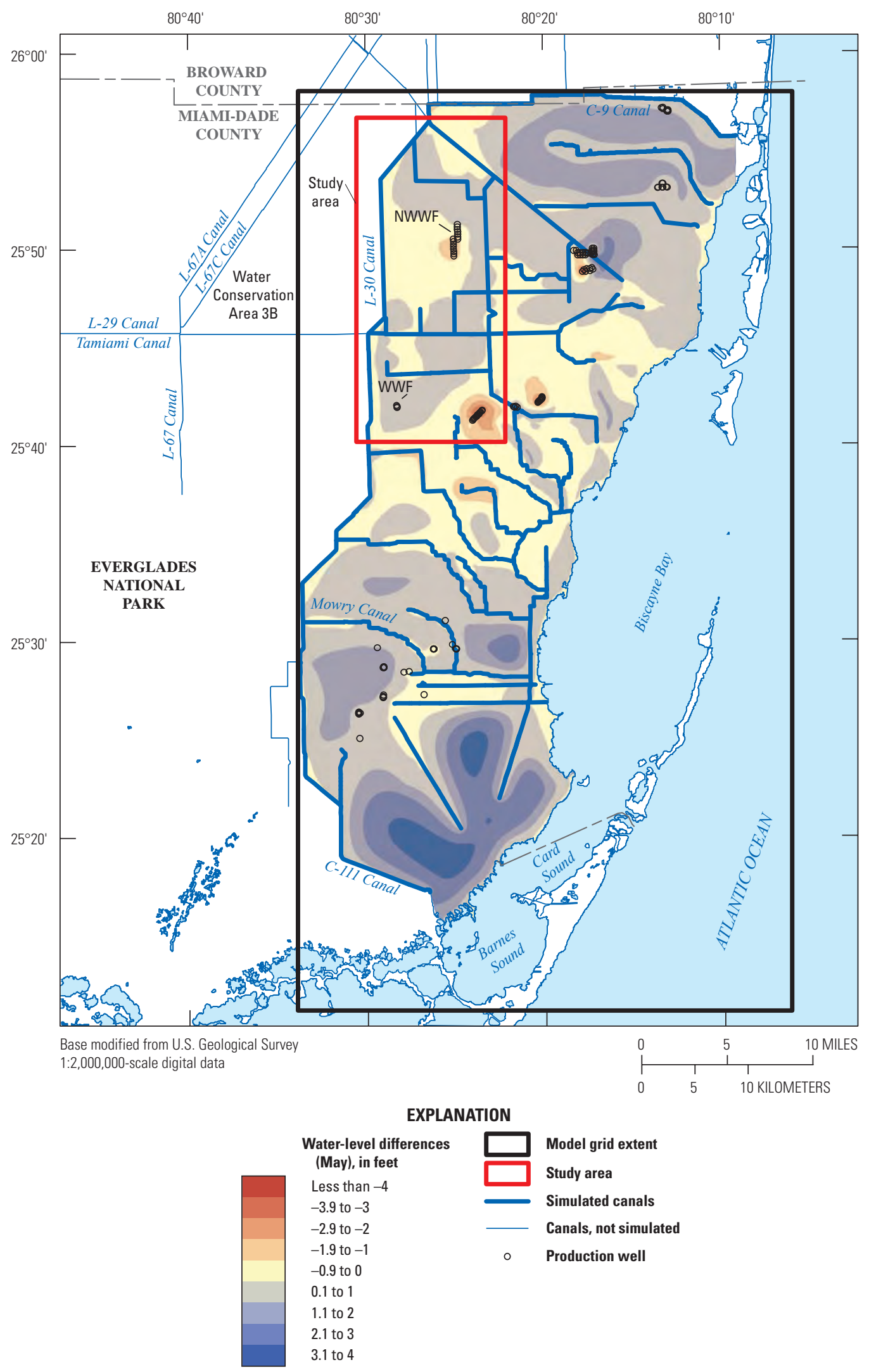

Figure 17. Average water-level differences for the Biscayne aquifer between May 1993 (observed) and May 1998 (simulated). Area shown is Base map 1 (fig. 1). White shaded area within model boundary comprises inactive areas of model. NWWF is Northwest Well Field. WWF is West Well Field. 


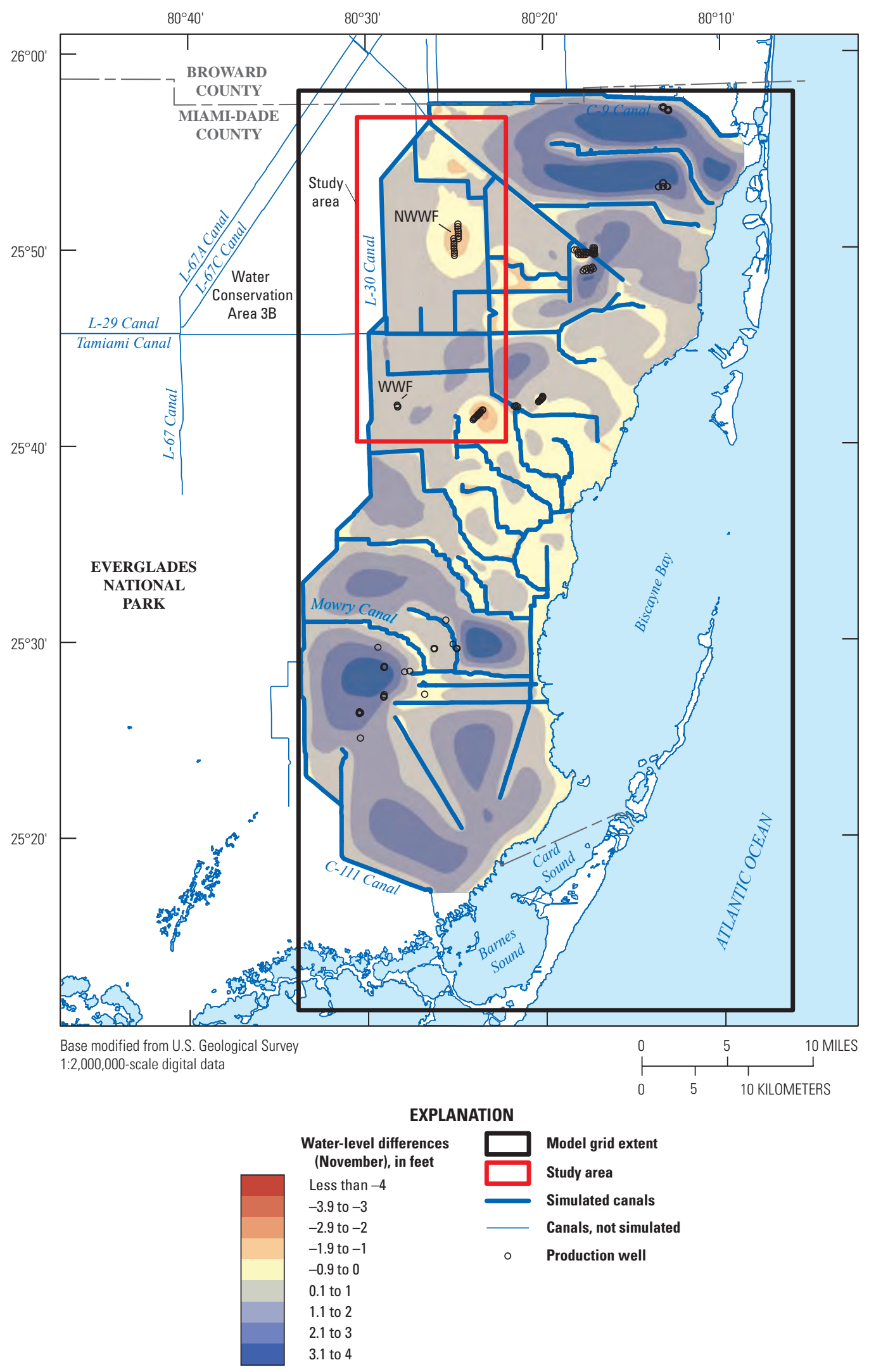

Figure 18. Average water-level differences for the Biscayne aquifer between November 1993 (observed) and November 1998 (simulated). Area shown is Base map 1 (fig. 1). White shaded area within model boundary comprises inactive areas of model. NWWF is Northwest Well Field. WWF is West Well Field. 


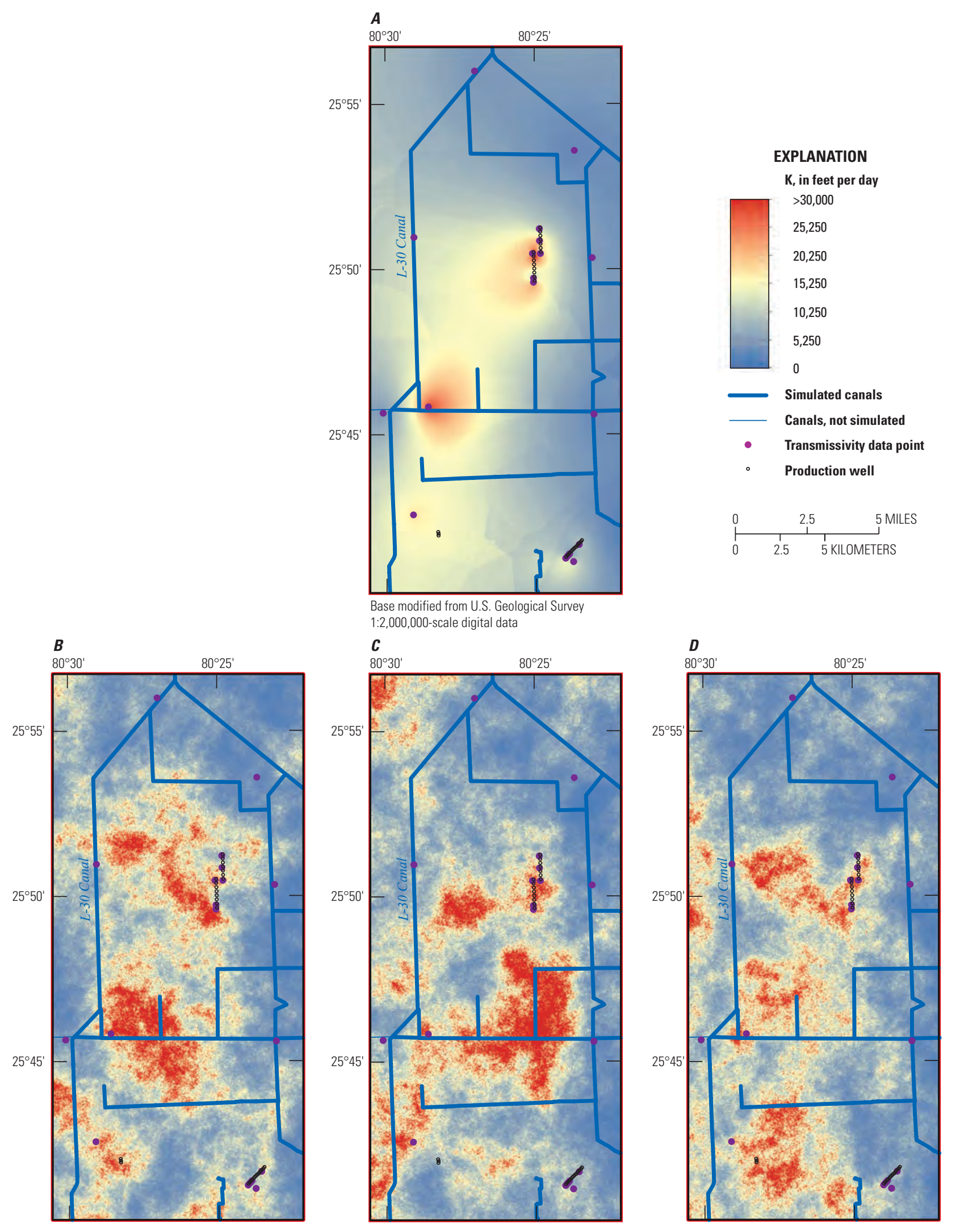

Figure 19. Hydraulic conductivity field used in transient and deterministic base-case steady-state simulations in the study area for the $(A)$ base-case simulation, and $(B, C$ and $D)$ for three selected additional realizations. These realizations are products of the multiplier array and the base-case hydraulic conductivity field, and do not have lake cells replaced with calculated bulk hydraulic conductivities. 


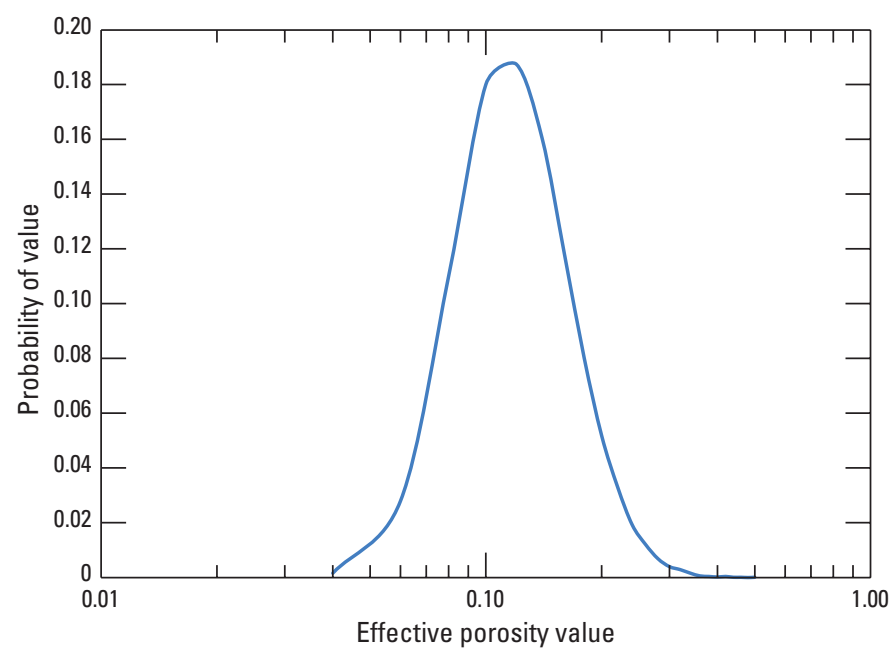

Figure 20. Log-normal probability distribution of effective porosity used for sampling of random values for Monte Carlo analysis. Values range from 0.04 to 0.50 . 


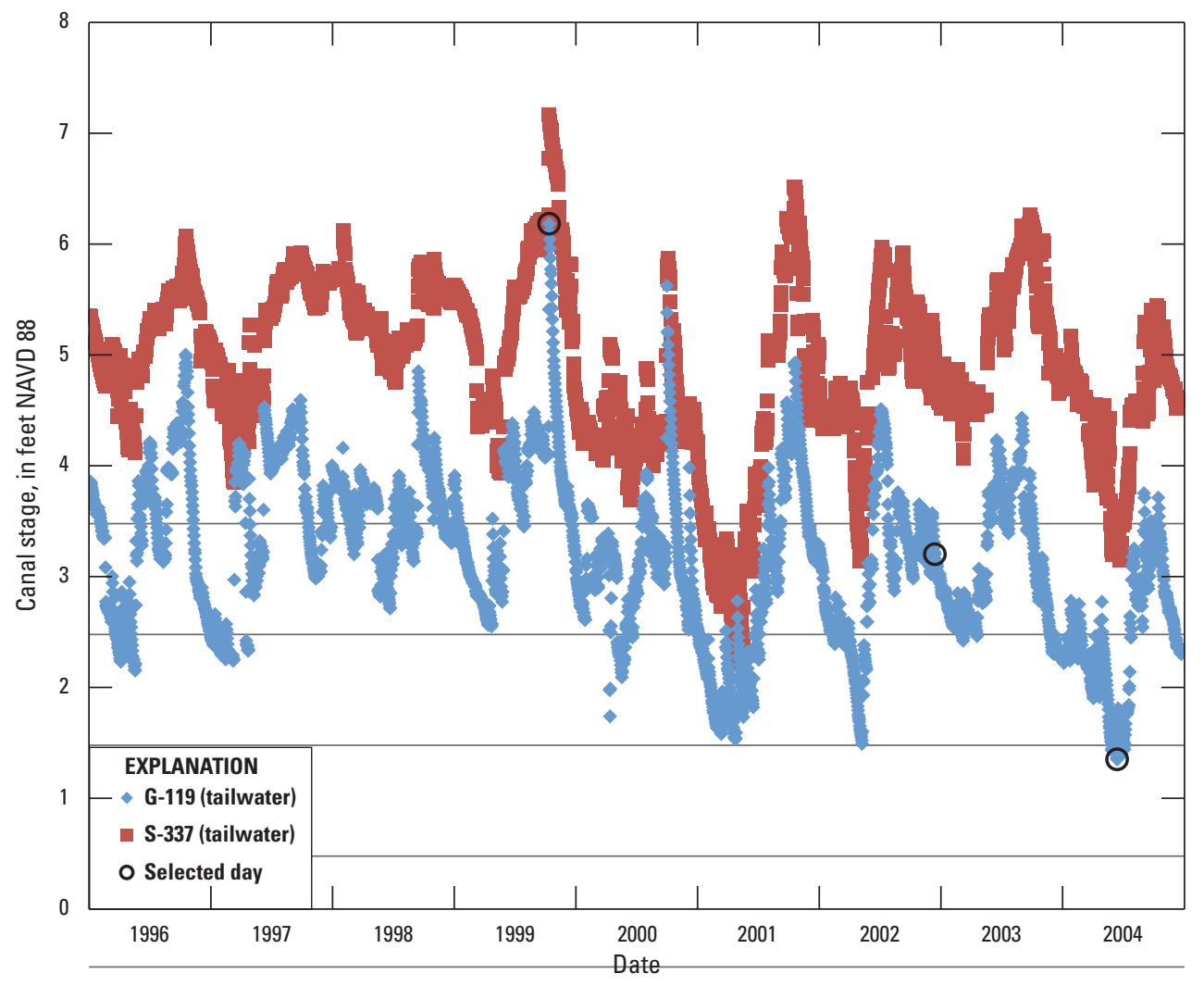

Figure 21. Tailwater stages at S-337 and G-119 with selected days representing dry, average, and wet hydrologic conditions identified with black circles. 


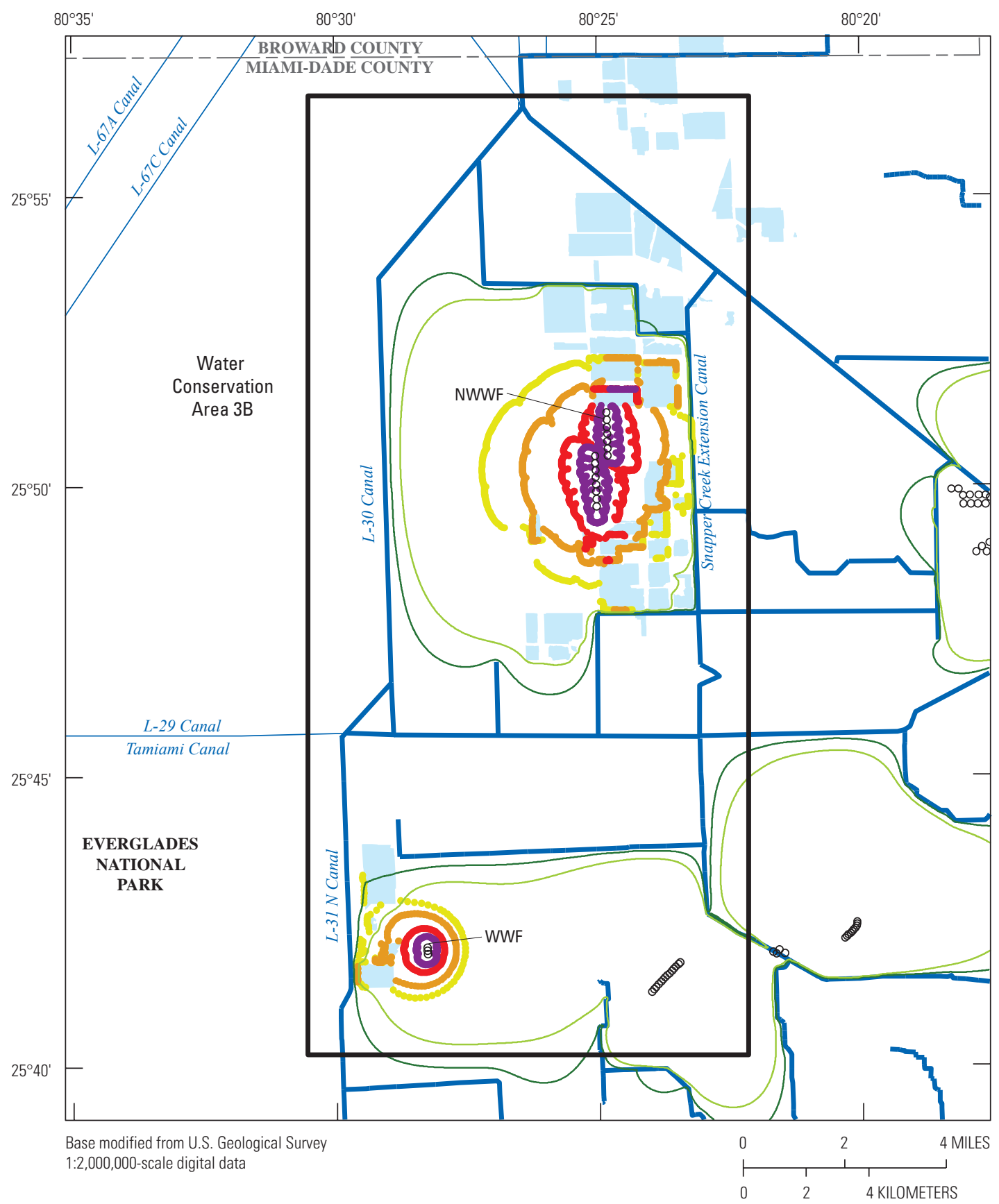

EXPLANATION

\begin{tabular}{lll}
\hline Lakes (2004) & $\circ$ & $\begin{array}{c}\text { Production well } \\
\text { Study area }\end{array}$ \\
$\square$ & & $\begin{array}{c}\text { Particle endpoints, } \\
\text { days of travel }\end{array}$ \\
\hline 0.1-foot drawdown & - & 10 \\
0.25-foot drawdown & - & 30 \\
Simulated canals & -100 \\
Canals, not simulated & 210
\end{tabular}

Figure 22. Simulated 0.25 -foot and 0.1 -foot drawdown contours, and particle endpoints for travel times of 10, 30, 100, and 210 days for the base-case simulation of dry conditions (June 19, 2004). Area shown is Base map 2 (fig. 1). NWWF is Northwest Well Field. WWF is West Well Field. 


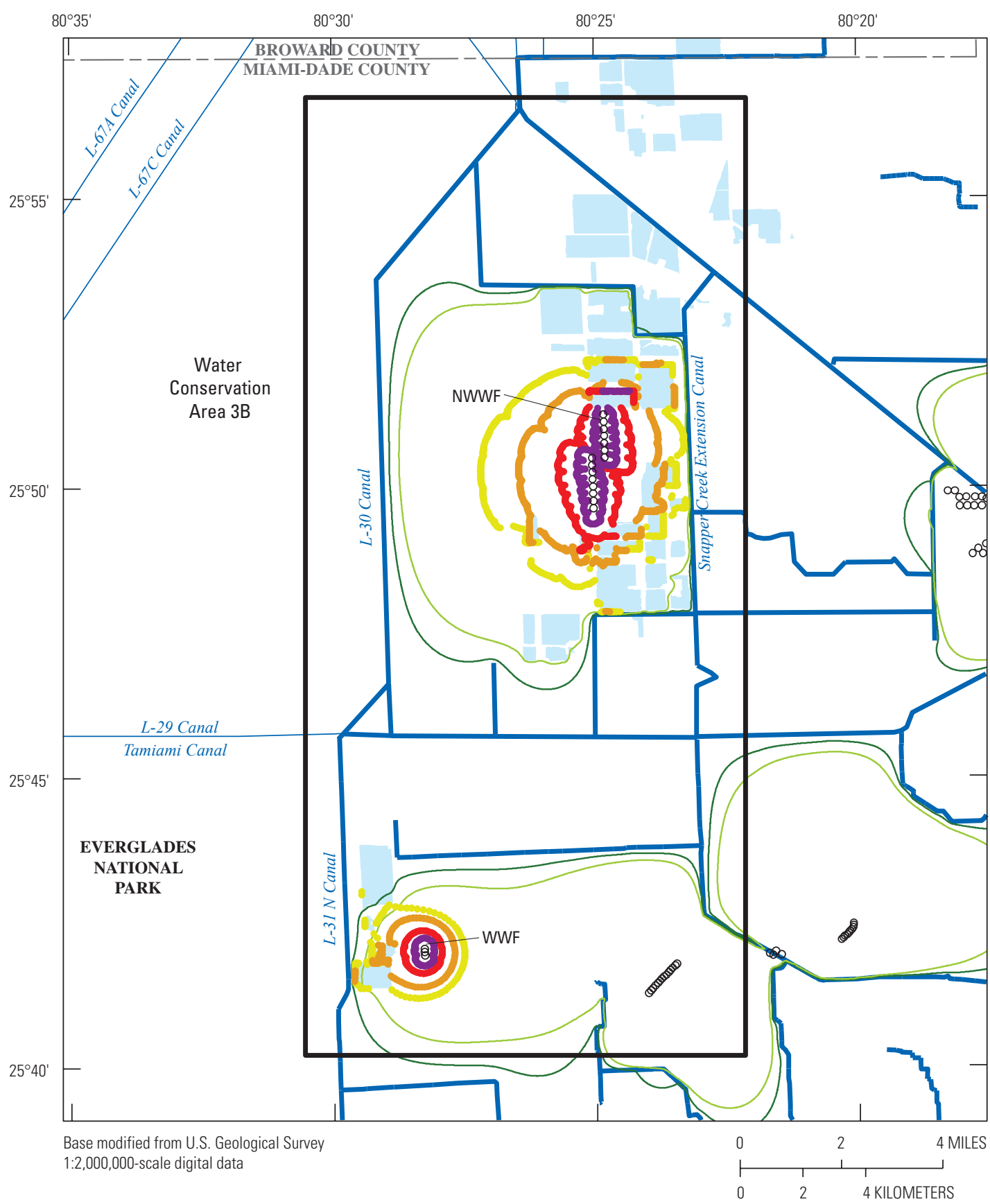

EXPLANATION

\begin{tabular}{lll}
\hline Lakes (2004) & $\circ$ & $\begin{array}{c}\text { Production well } \\
\text { Study area }\end{array}$ \\
\hline 0.1-foot drawdown & & $\begin{array}{c}\text { Particle endpoints, } \\
\text { days of travel }\end{array}$ \\
\hline 0.25-foot drawdown & - & 10 \\
Simulated canals & - & 30 \\
Canals, not simulated & & 210 \\
\hline
\end{tabular}

Figure 23. Simulated 0.25 -foot and 0.1 -foot drawdown contours, and particle endpoints for travel times of 10, 30, 100, and 210 days for the base-case simulation of average conditions (December 19, 2002). Area shown is Base map 2 (fig. 1). NWWF is Northwest Well Field. WWF is West Well Field. 


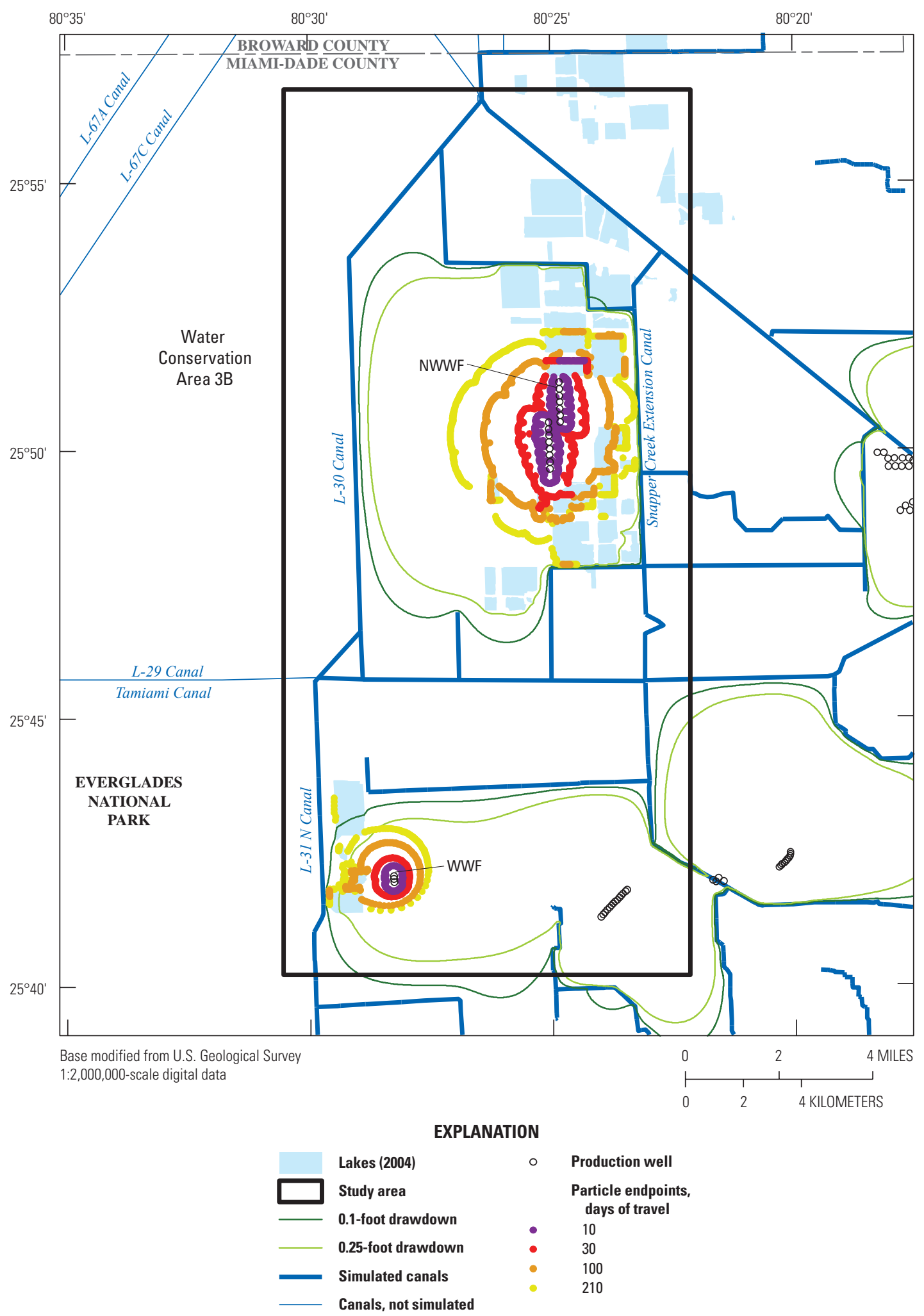

Figure 24. Simulated 0.25 -foot and 0.1 -foot drawdown contours, and particle endpoints for travel times of 10, 30, 100, and 210 days for the base-case simulation of wet conditions (October 16, 1999). Area shown is Base map 2 (fig. 1). NWWF is Northwest Well Field. WWF is West Well Field. 


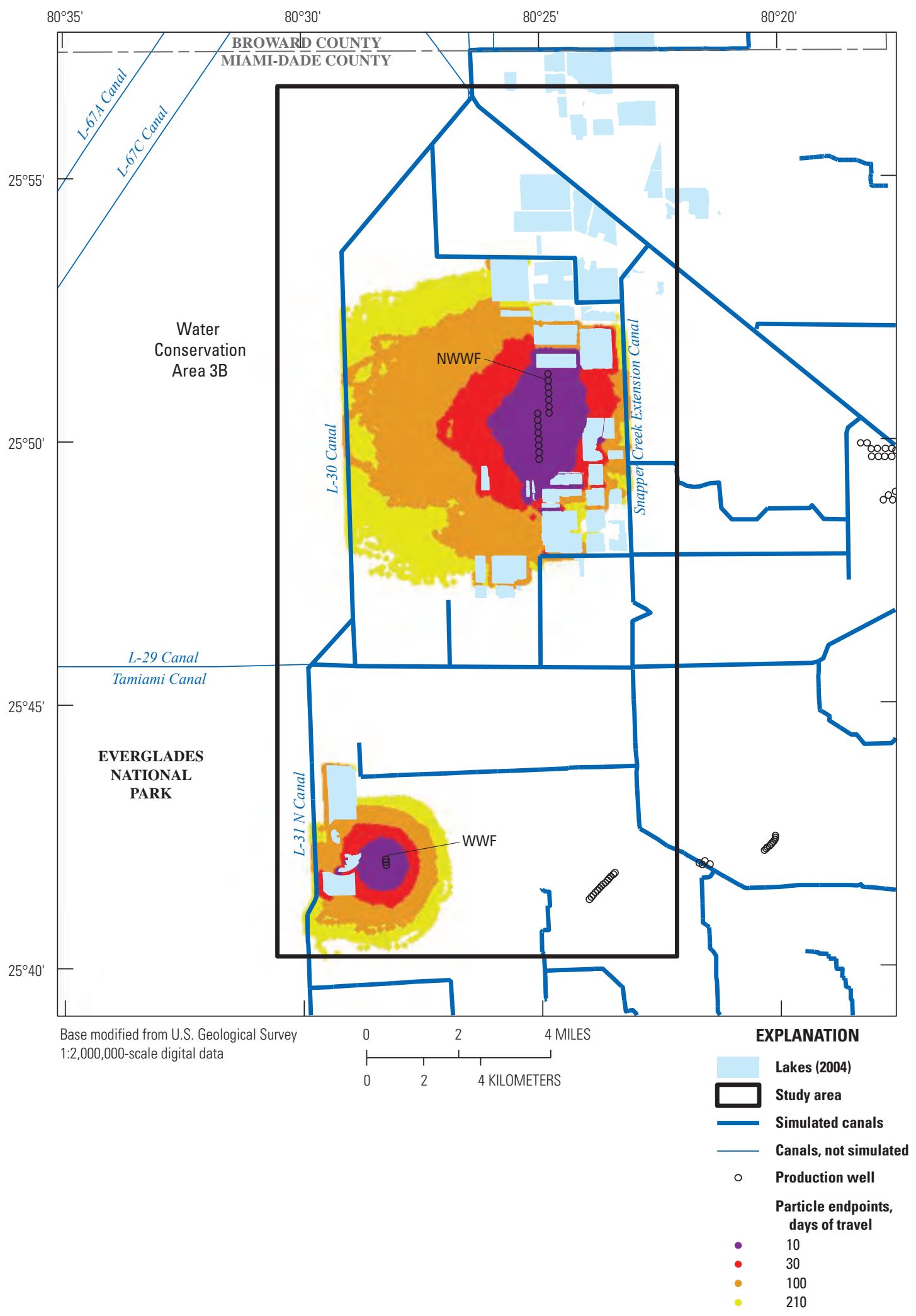

Figure 25. Simulated particle endpoint locations for travel times of 10,30, 100, and 210 days for dry conditions for 10,000 realizations. Area shown is Base map 2 (fig. 1). NWWF is Northwest Well Field. WWF is West Well Field. 


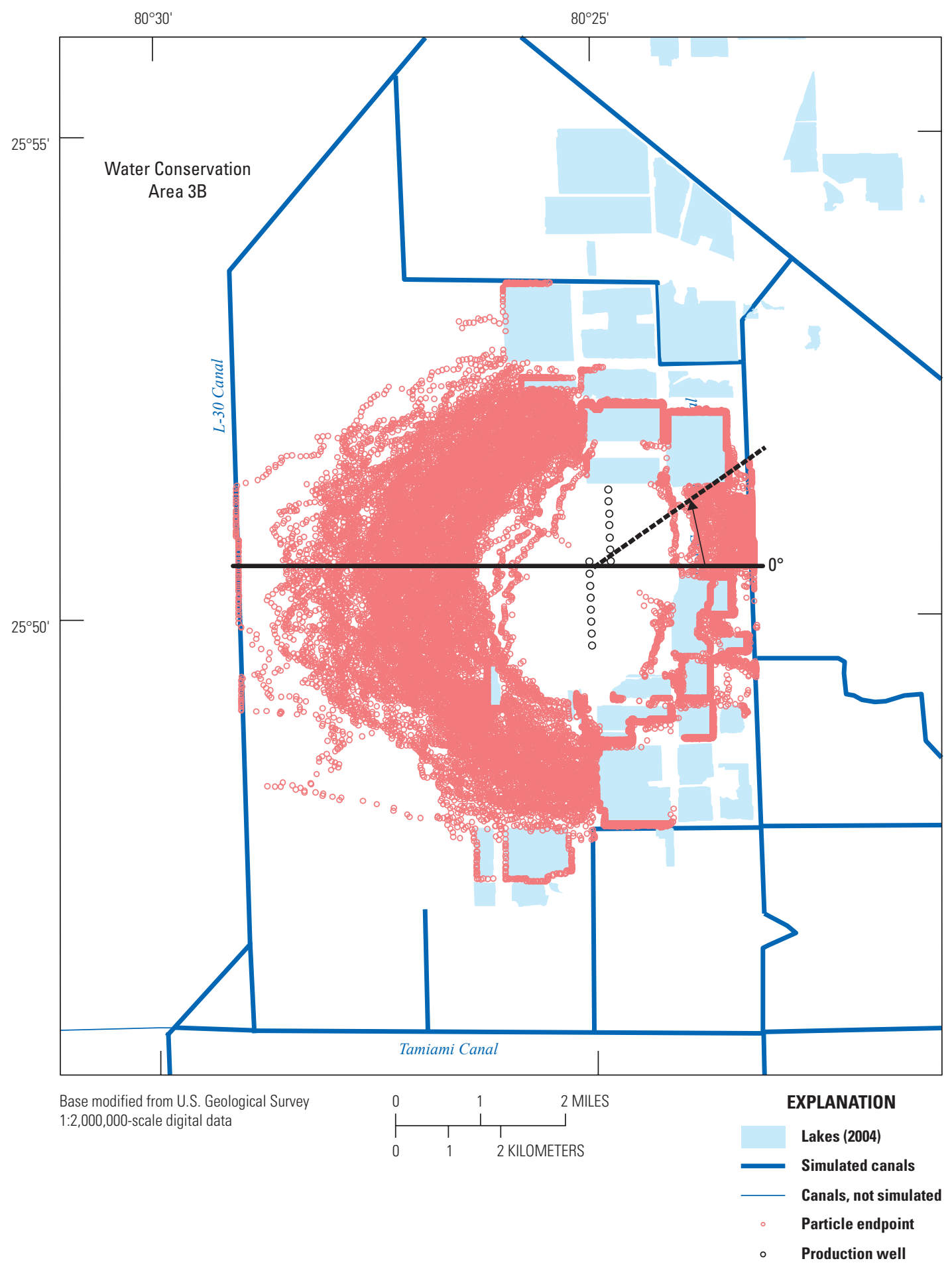

Figure 26. Simulated particle endpoint locations for 210 days of travel for dry conditions for 100 realizations around the Northwest Well Field (NWWF), and an example of the radial class division described by Varljen and Shafer (1991). Area shown is Base map 4 (fig. 1). 


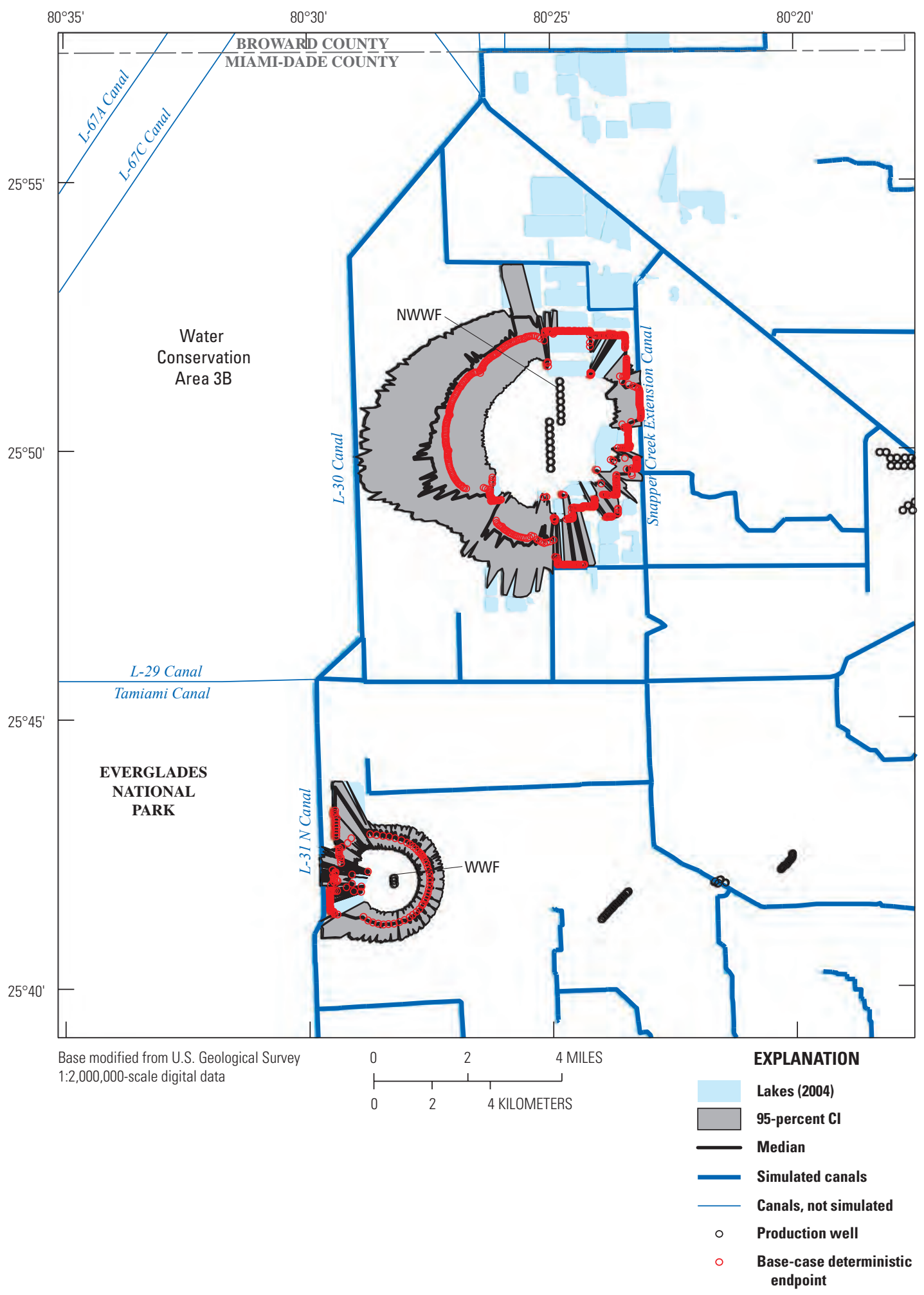

Figure 27. Median and 95-percent confidence intervals for the 210-day capture zones for the Northwest Well Field (NWWF) and West Well Field (WWF) for steady-state, dry conditions, and particle endpoints for 210 days of travel for the base-case simulation of dry conditions. Area shown is Base map 2 (fig. 1). 


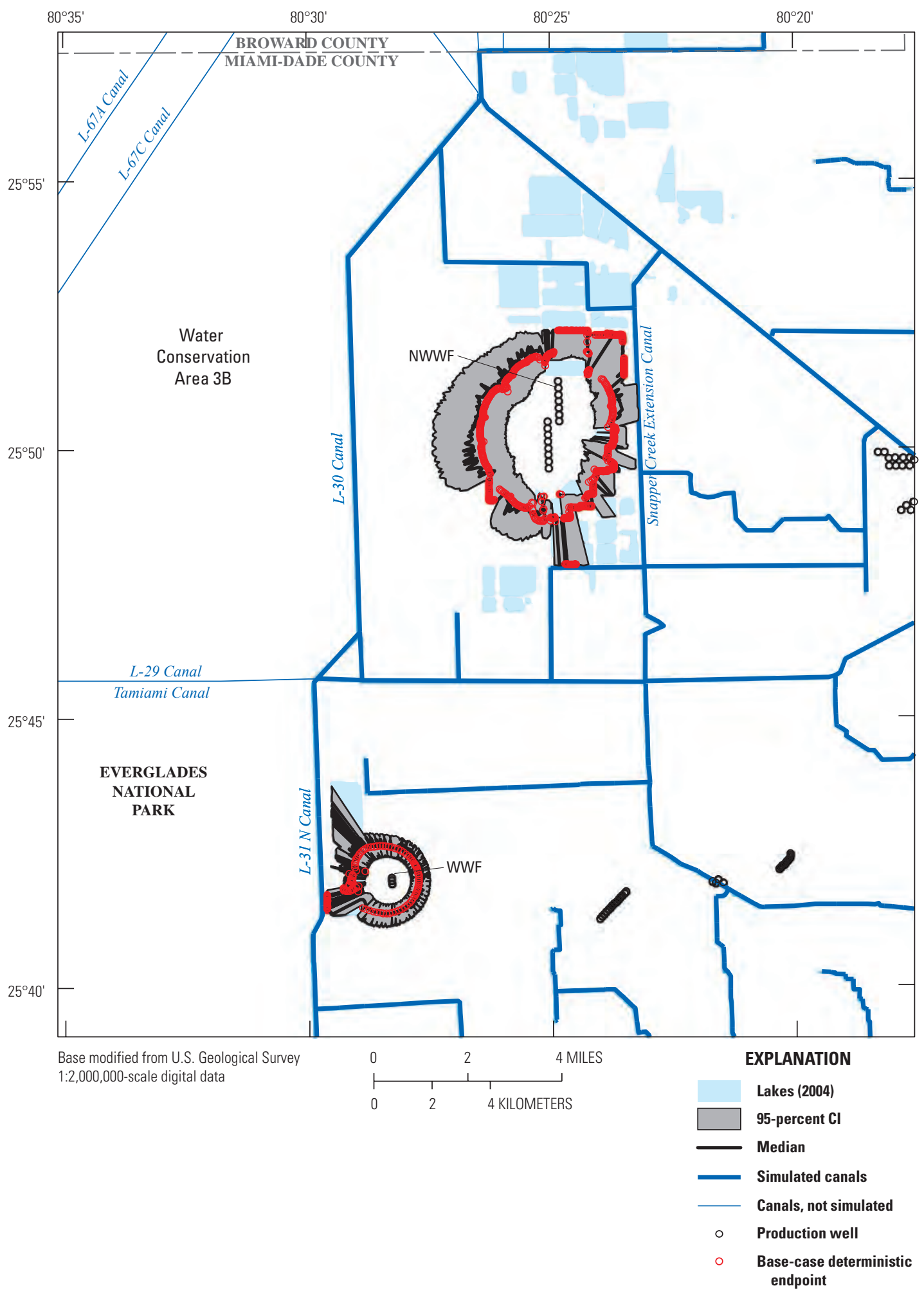

Figure 28. Median and 95-percent confidence intervals for the 100-day capture zones for the Northwest Well Field (NWWF) and West Well Field (WWF) for steady-state, dry conditions, and particle endpoints for 100 days of travel for the base-case simulation of dry conditions. Area shown is Base map 2 (fig. 1). 


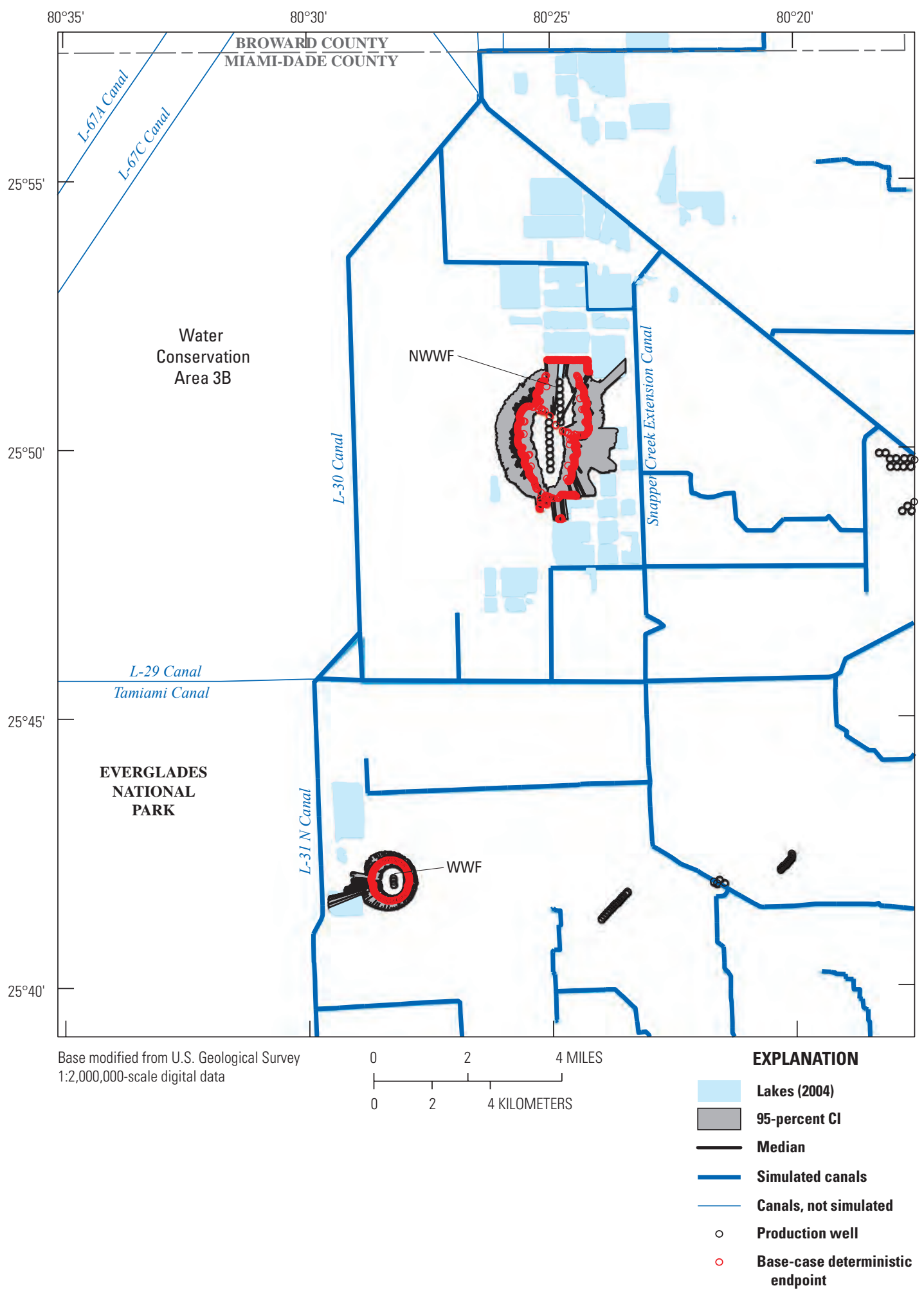

Figure 29. Median and 95-percent confidence intervals for the 30-day capture zones for the Northwest Well Field (NWWF) and West Well Field (WWF) for steady-state dry conditions, and particle endpoints for 30 days of travel for the base-case simulation of dry conditions. Area shown is Base map 2 (fig. 1). 


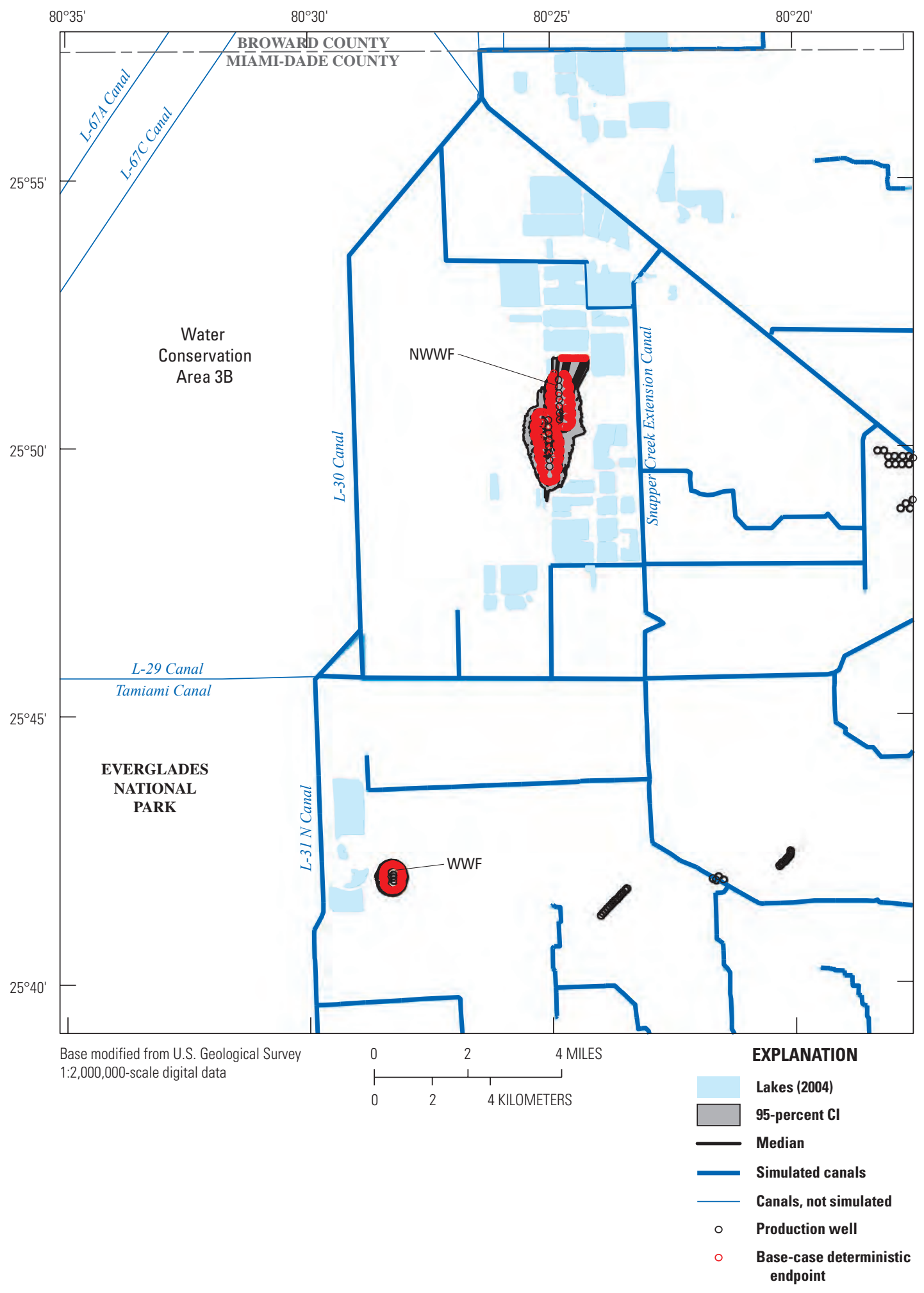

Figure 30. Median and 95-percent confidence intervals for the 10-day capture zones for the Northwest Well Field (NWWF) and West Well Field (WWF) for steady-state, dry conditions, and particle endpoints for 10 days of travel for the base-case simulation of dry conditions. Area shown is Base map 2 (fig. 1). 


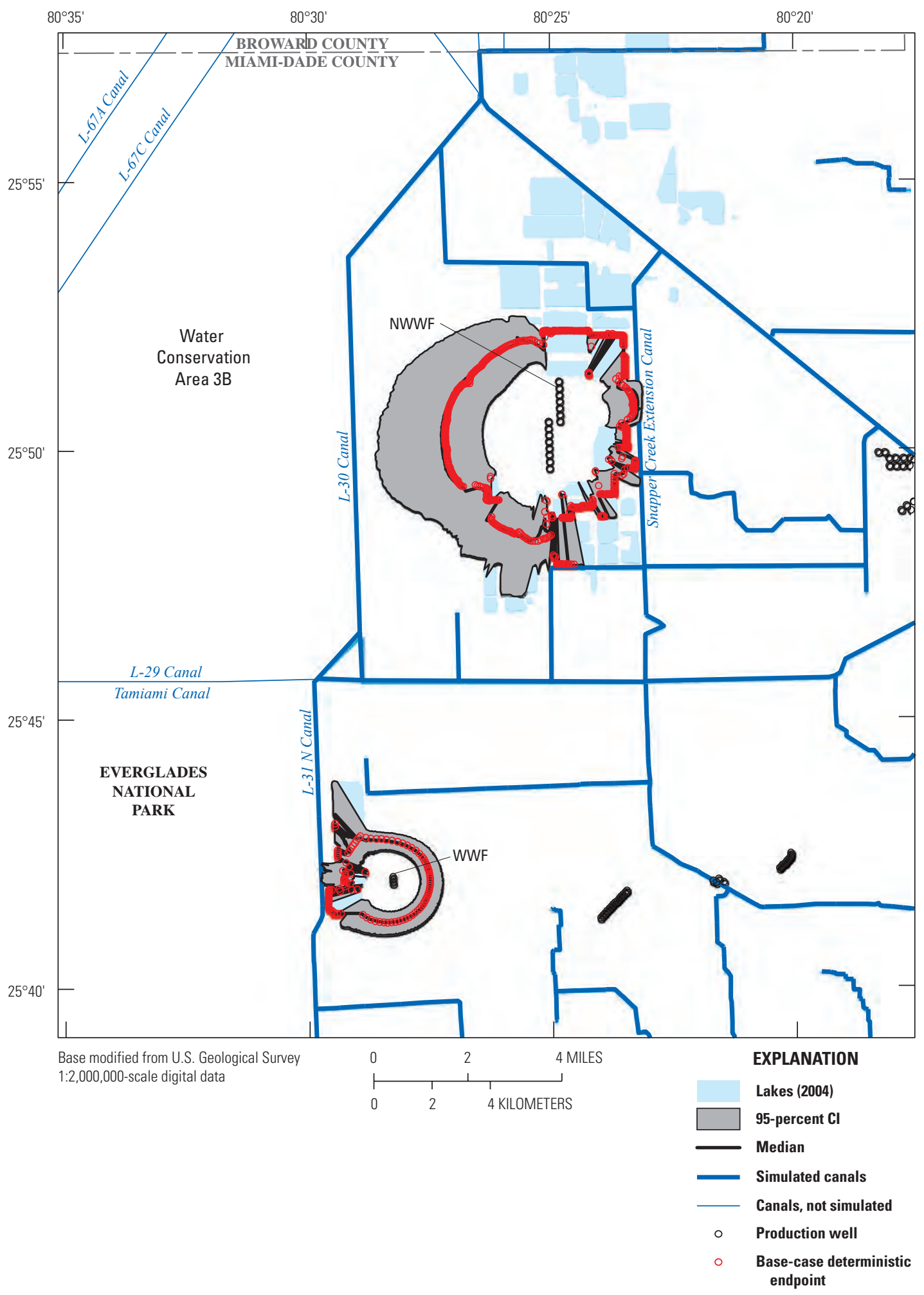

Figure 31. Median and 95-percent confidence intervals for the 210-day capture zones for the Northwest Well Field (NWWF) and West Well Field (WWF) for steady-state, average conditions, and particle endpoints for 210 days of travel for the base-case simulation of average conditions. Area shown is Base map 2 (fig. 1). 


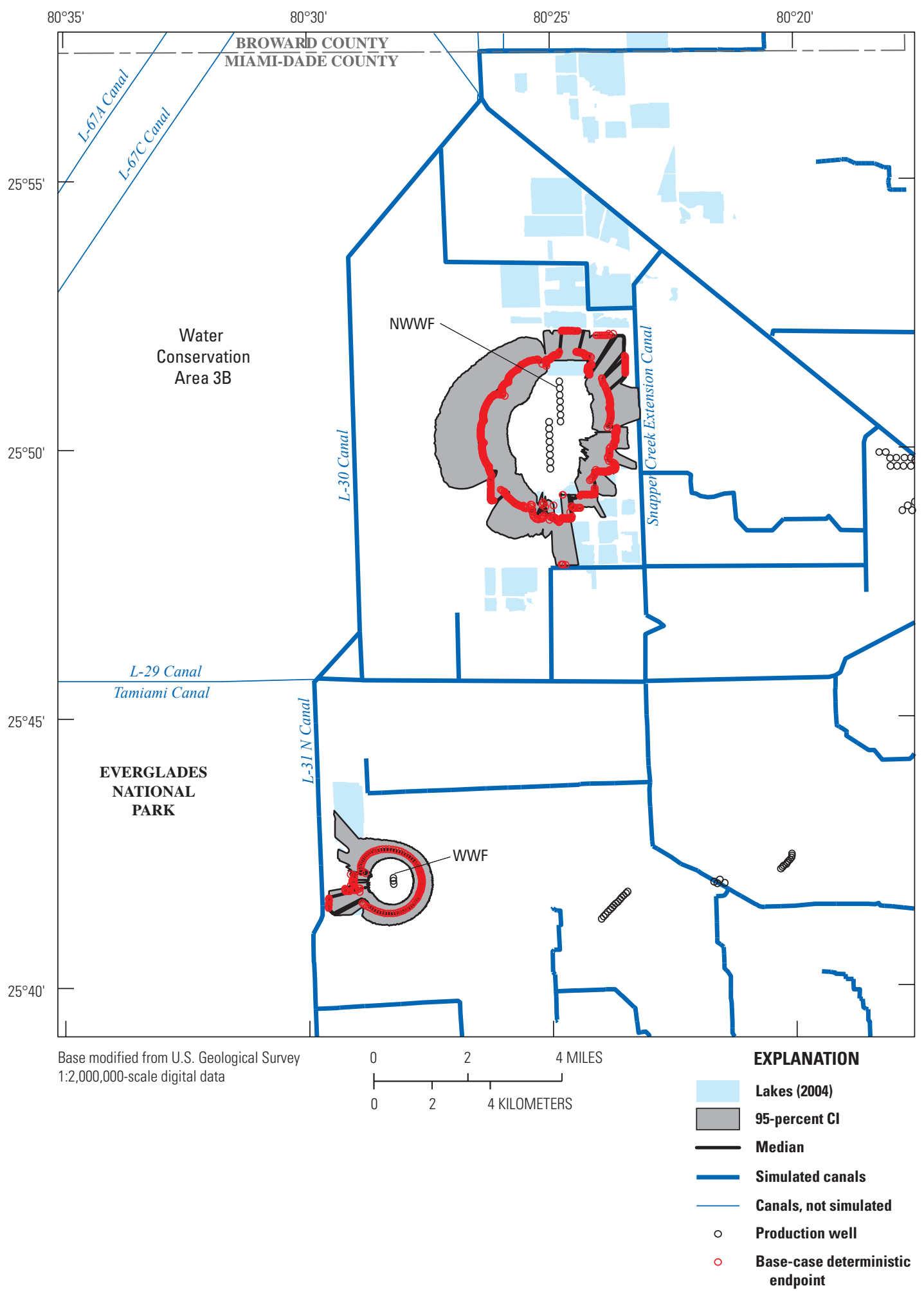

Figure 32. Median and 95-percent confidence intervals for the 100-day capture zones for the Northwest Well Field (NWWF) and West Well Field (WWF) for steady-state, average conditions, and particle endpoints for 100 days of travel for the base-case simulation of average conditions. Area shown is Base map 2 (fig. 1). 


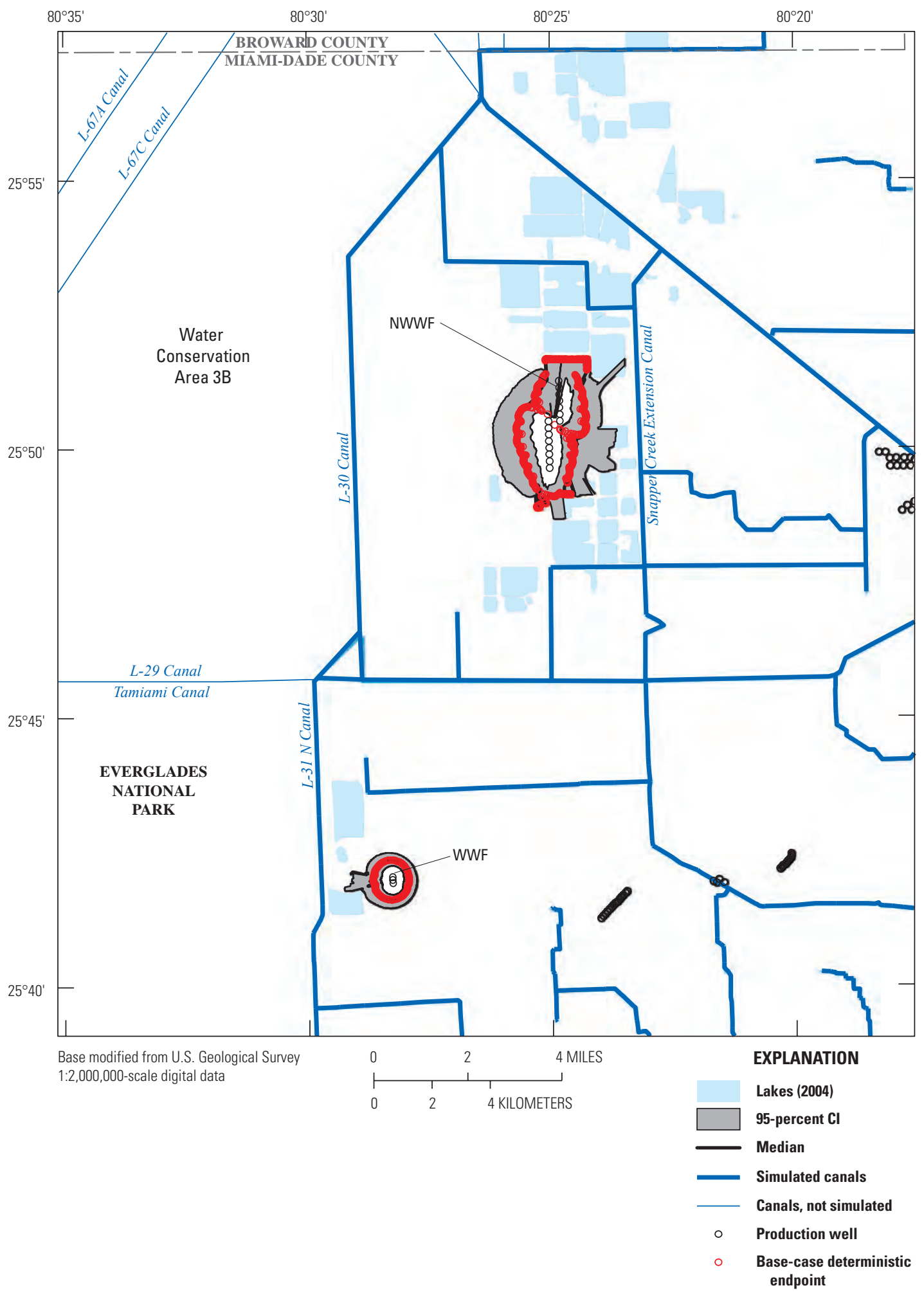

Figure 33. Median and 95-percent confidence intervals for the 30-day capture zones for the Northwest Well Field (NWWF) and West Well Field (WWF) for steady-state, average conditions, and particle endpoints for 30 days of travel for the base-case simulation of average conditions. Area shown is Base map 2 (fig. 1). 


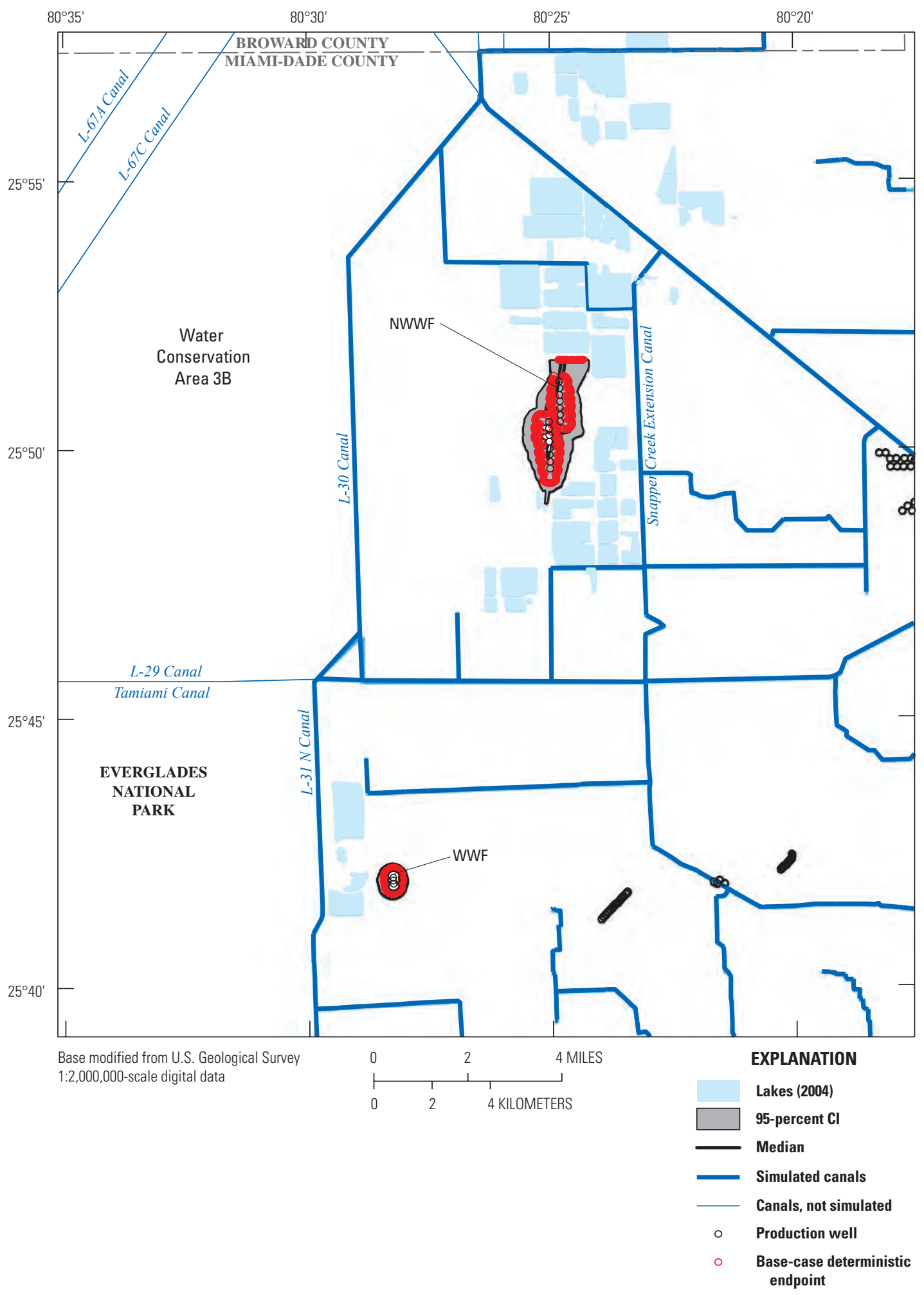

Figure 34. Median and 95-percent confidence intervals for the 10-day capture zones for the Northwest Well Field (NWWF) and West Well Field (WWF) for steady-state, average conditions, and particle endpoints for 10 days of travel for the base-case simulation of average conditions. Area shown is Base map 2 (fig. 1). 


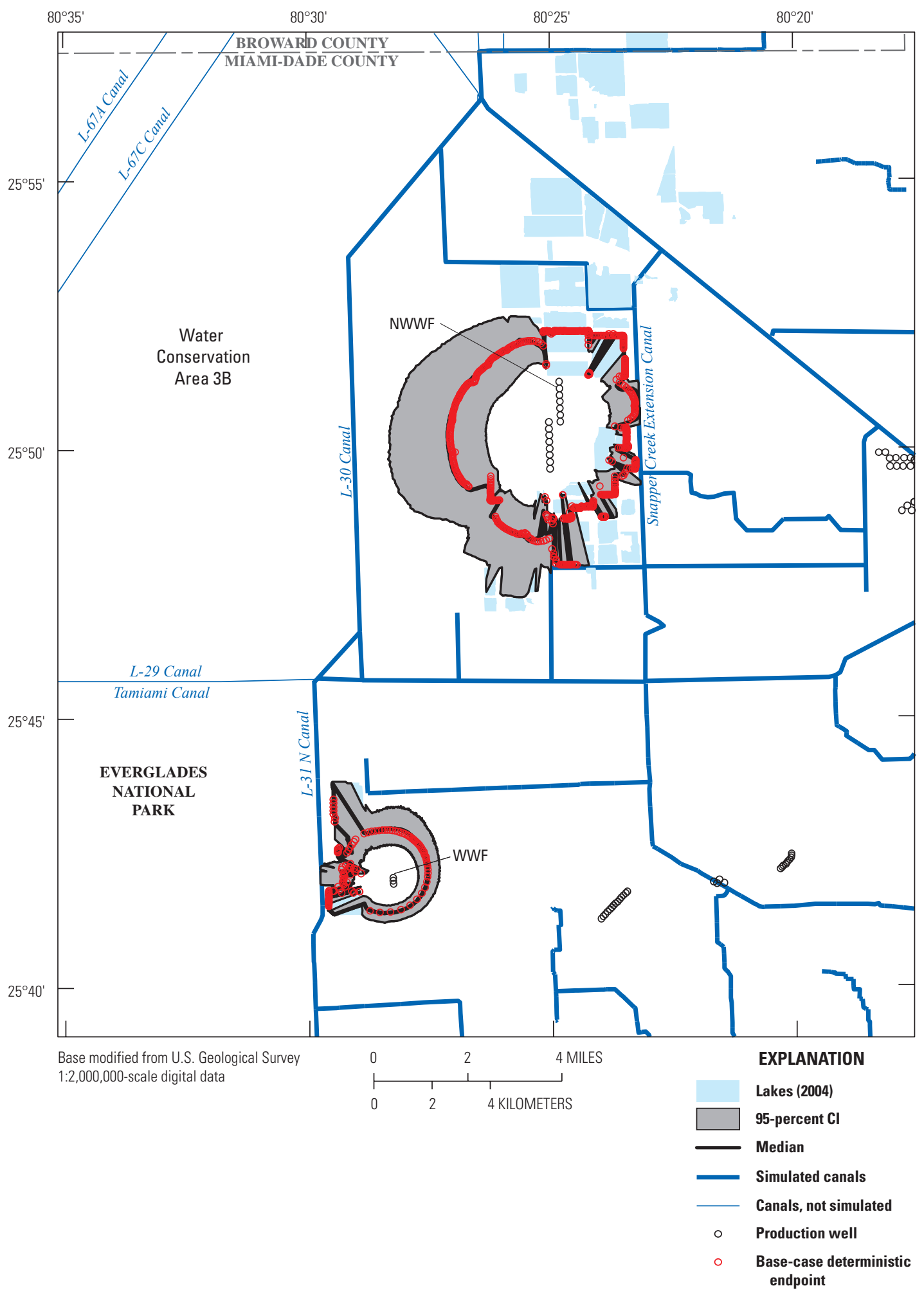

Figure 35. Median and 95-percent confidence intervals for the 210-day capture zones for the Northwest Well Field (NWWF) and West Well Field (WWF) for steady-state, wet conditions, and particle endpoints for 210 days of travel for the base-case simulation of wet conditions. Area shown is Base map 2 (fig. 1). 


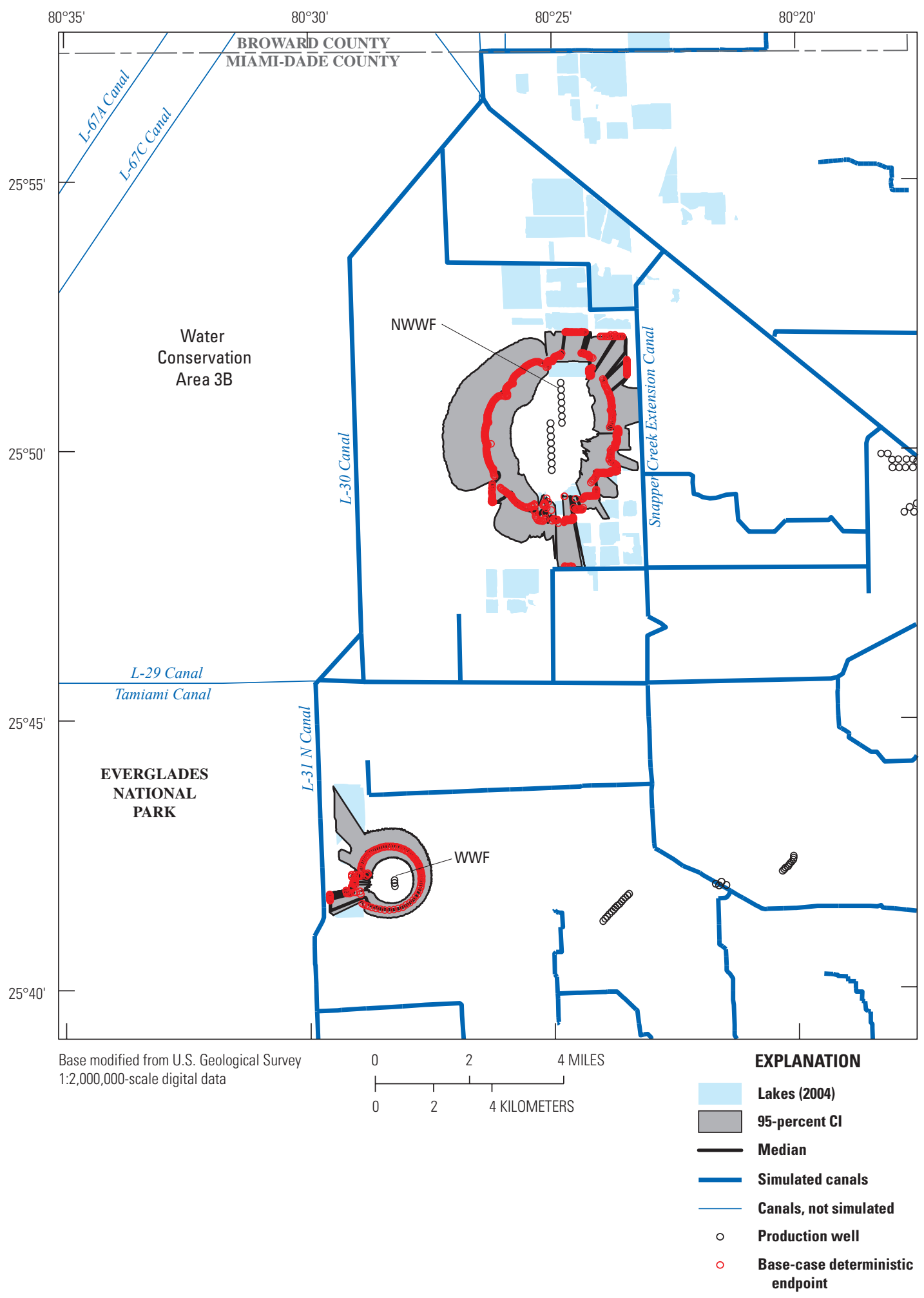

Figure 36. Median and 95-percent confidence intervals for the 100-day capture zones for the Northwest Well Field (NWWF) and West Well Field (WWF) for steady-state, wet conditions, and particle endpoints for 100 days of travel for the base-case simulation of wet conditions. Area shown is Base map 2 (fig. 1). 


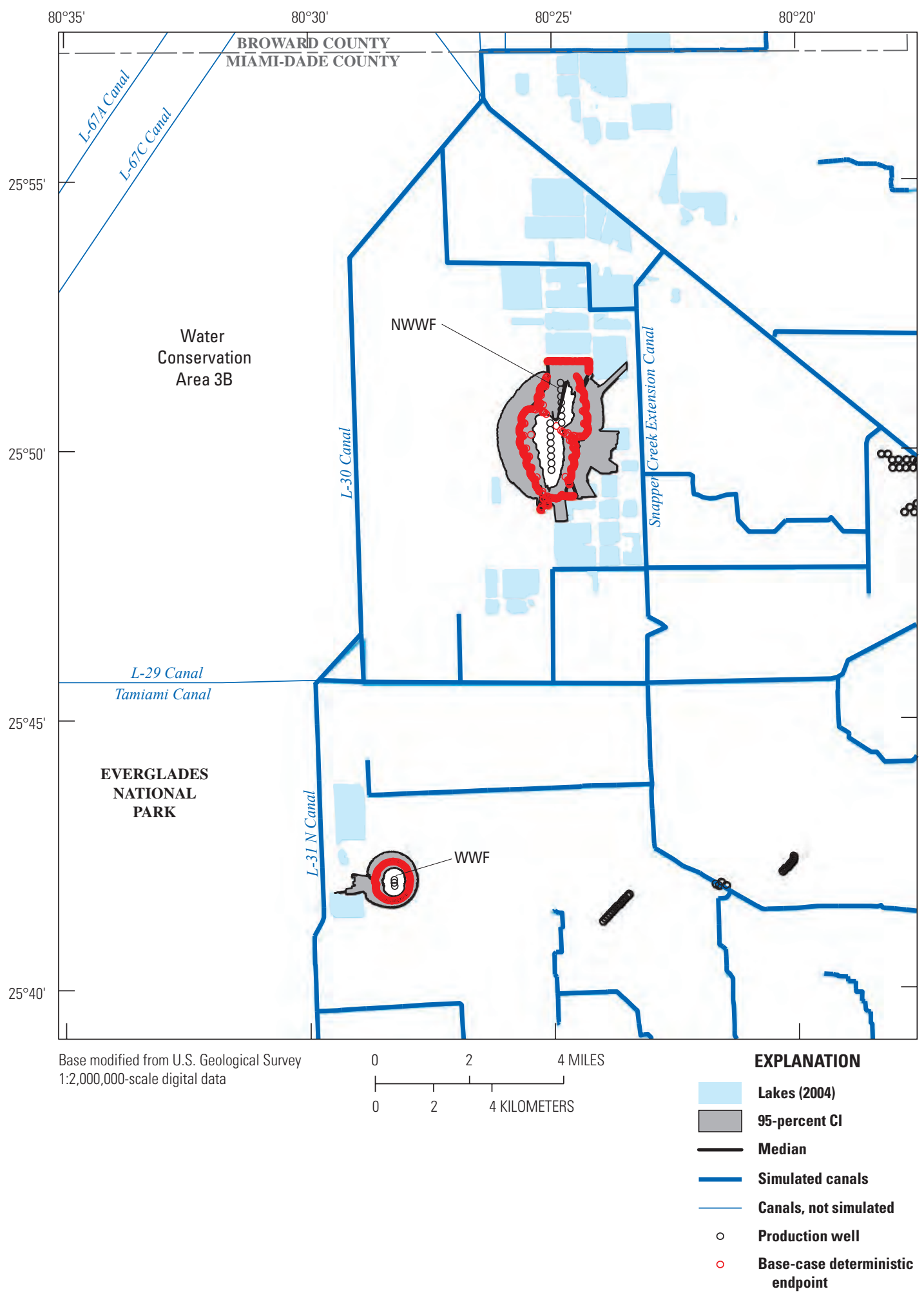

Figure 37. Median and 95-percent confidence intervals for the 30-day capture zones for the Northwest Well Field (NWWF) and West Well Field (WWF) for steady-state, wet conditions, and particle endpoints for 30 days of travel for the base-case simulation of wet conditions. Area shown is Base map 2 (fig. 1). 


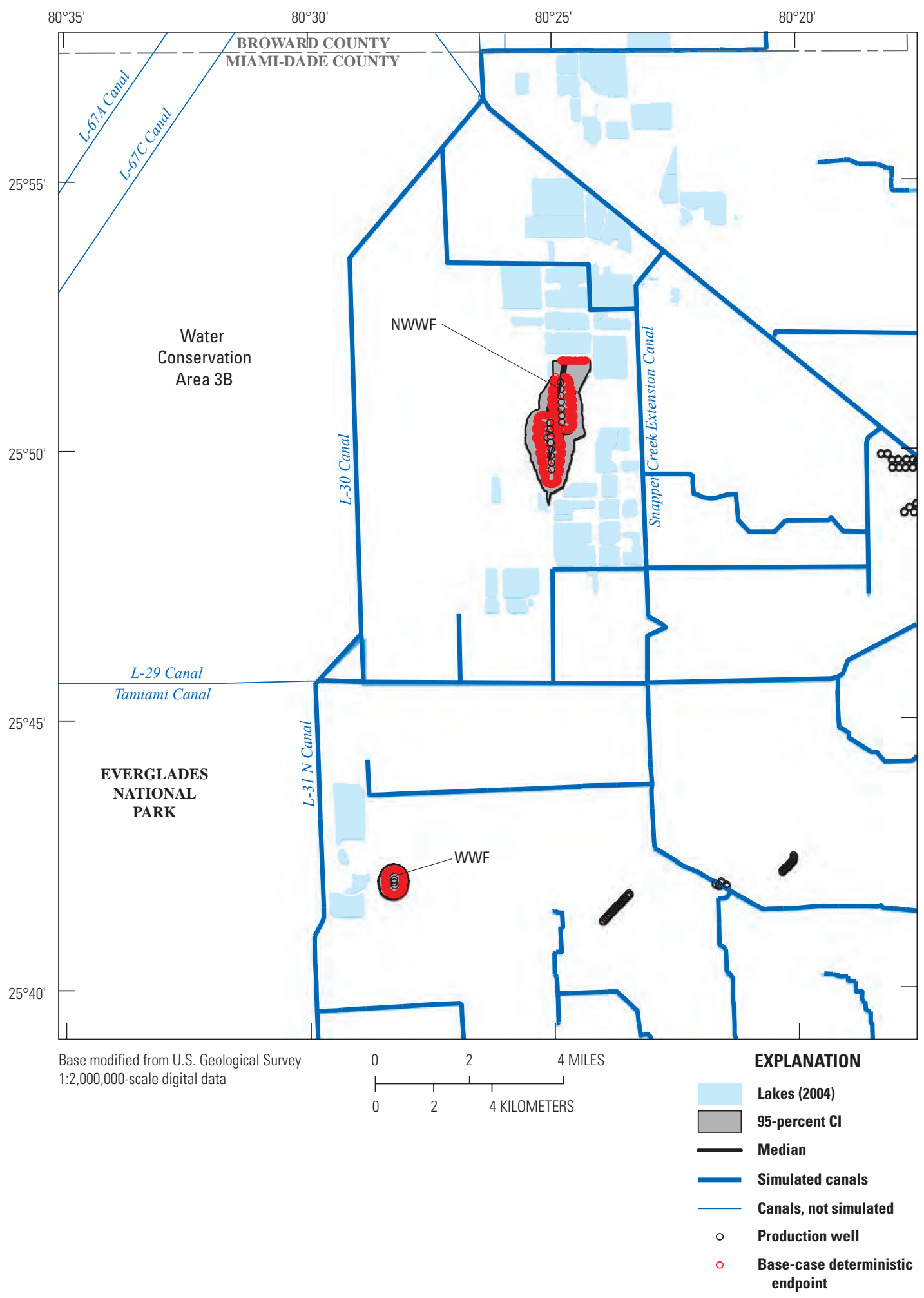

Figure 38. Median and 95-percent confidence intervals for the 10-day capture zones for the Northwest Well Field (NWWF) and West Well Field (WWF) for steady-state, wet conditions, and particle endpoints for 10 days of travel for the base-case simulation of wet conditions. Area shown is Base map 2 (fig. 1). 


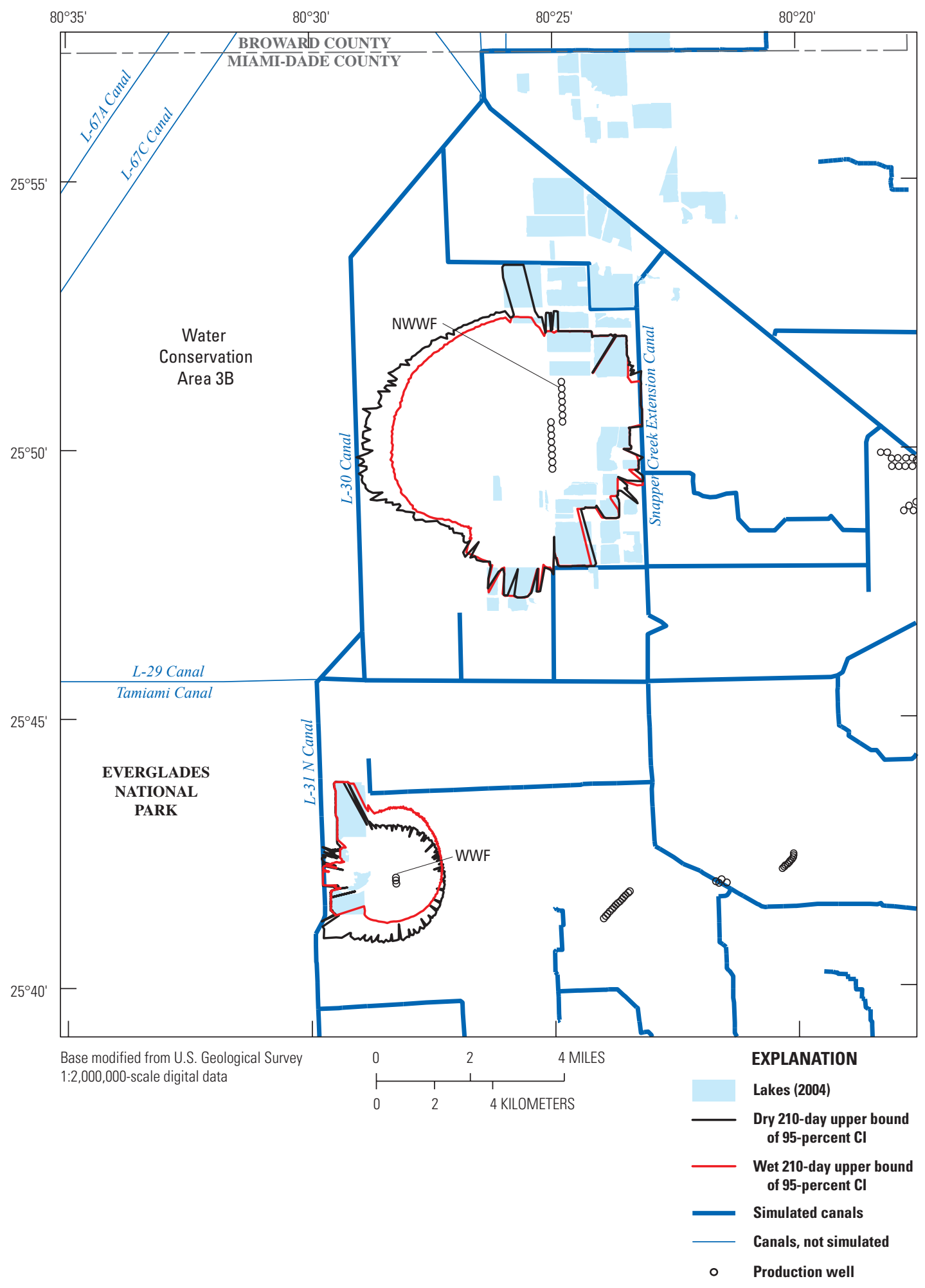

Figure 39. Upper bounds of the 95-percent confidence intervals (CI) for the 210-day capture zones for the Northwest Well Field (NWWF) and West Well Field (WWF) for steady-state, wet and dry conditions. Area shown is Base map 2 (fig. 1). 


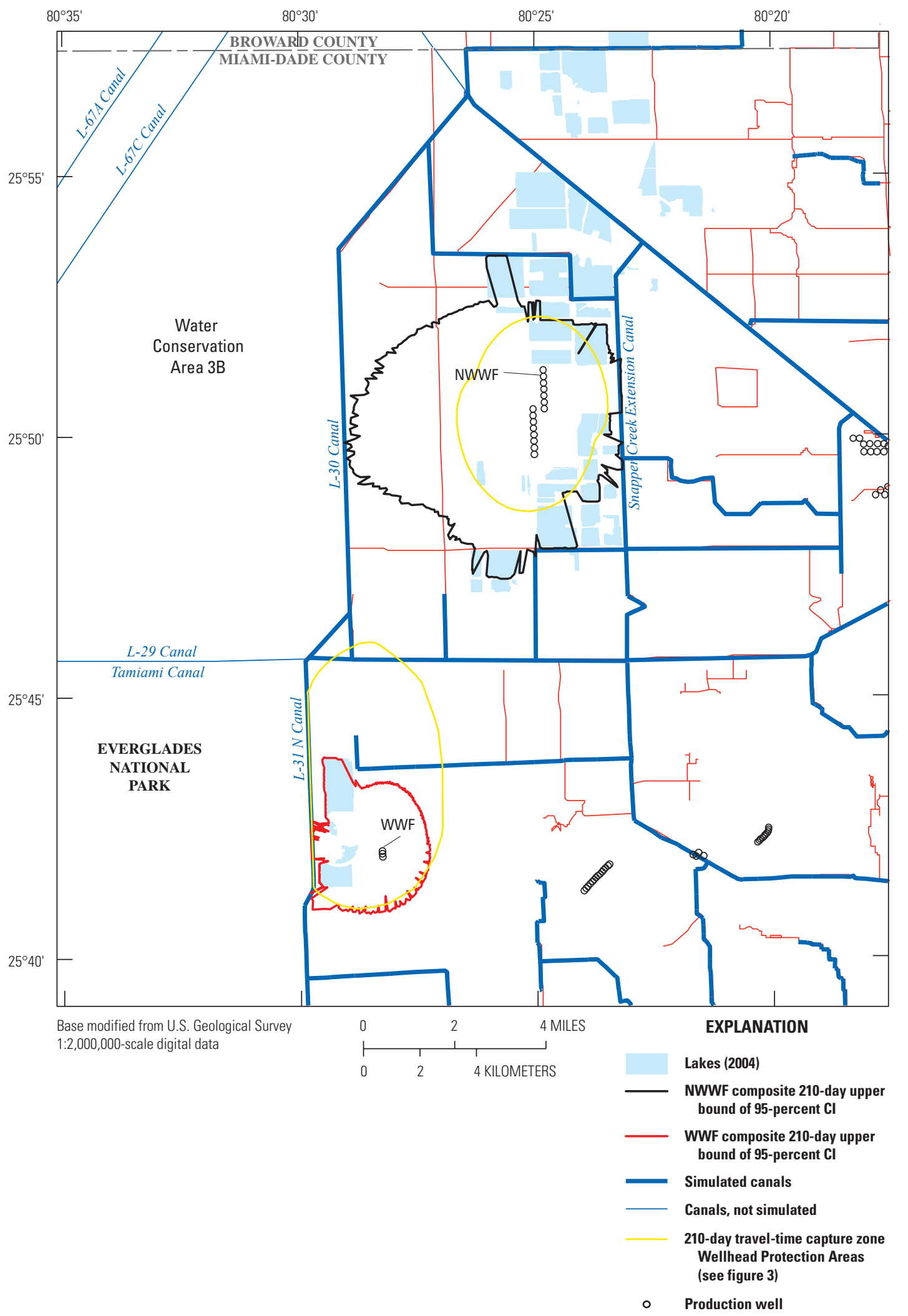

Figure 40. Composite areal extent of the upper bounds of the 95-percent confidence intervals $(\mathrm{Cl})$ for the 210-day capture zones for the Northwest Well Field (NWWF) and West Well Field (WWF) for steady-state, wet and dry conditions. Also shown are the current 210-day Wellhead Protection Areas for the NWWF and the WWF (fig. 3). Area shown is Base map 2 (fig. 1). 


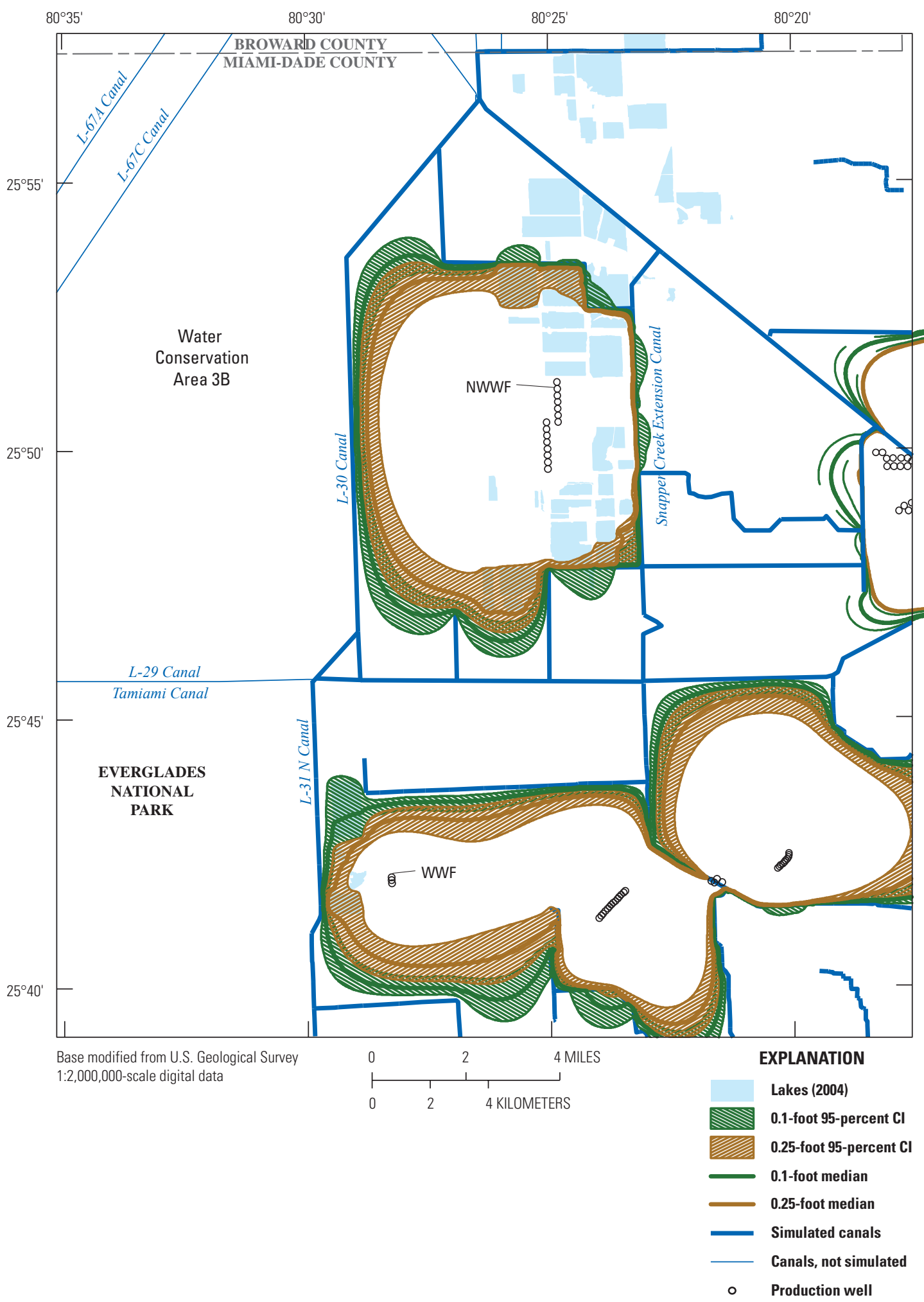

Figure 41. Median and 95-percent confidence intervals ( $\mathrm{Cl}$ ) for 0.1 -foot and 0.25 -foot drawdowns for the Northwest Well Field (NWWF) and West Well Field (WWF) for steady-state, dry conditions. Area shown is Base map 2 (fig. 1). 


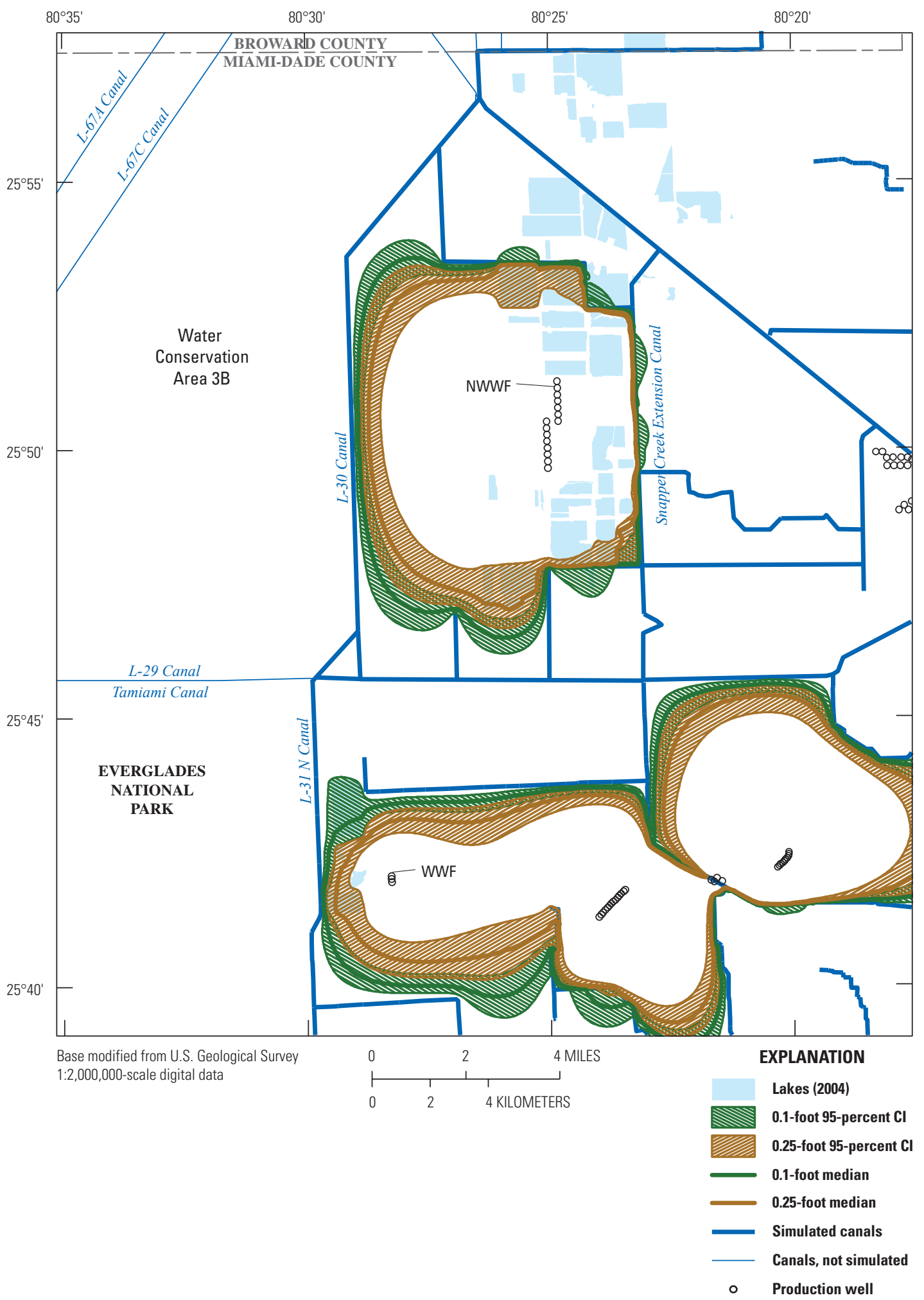

Figure 42. Median and 95-percent confidence intervals ( $\mathrm{Cl}$ ) for 0.1 -foot and 0.25 -foot drawdowns for the Northwest Well Field (NWWF) and West Well Field (WWF) for steady-state, average conditions. Area shown is Base map 2 (fig. 1). 


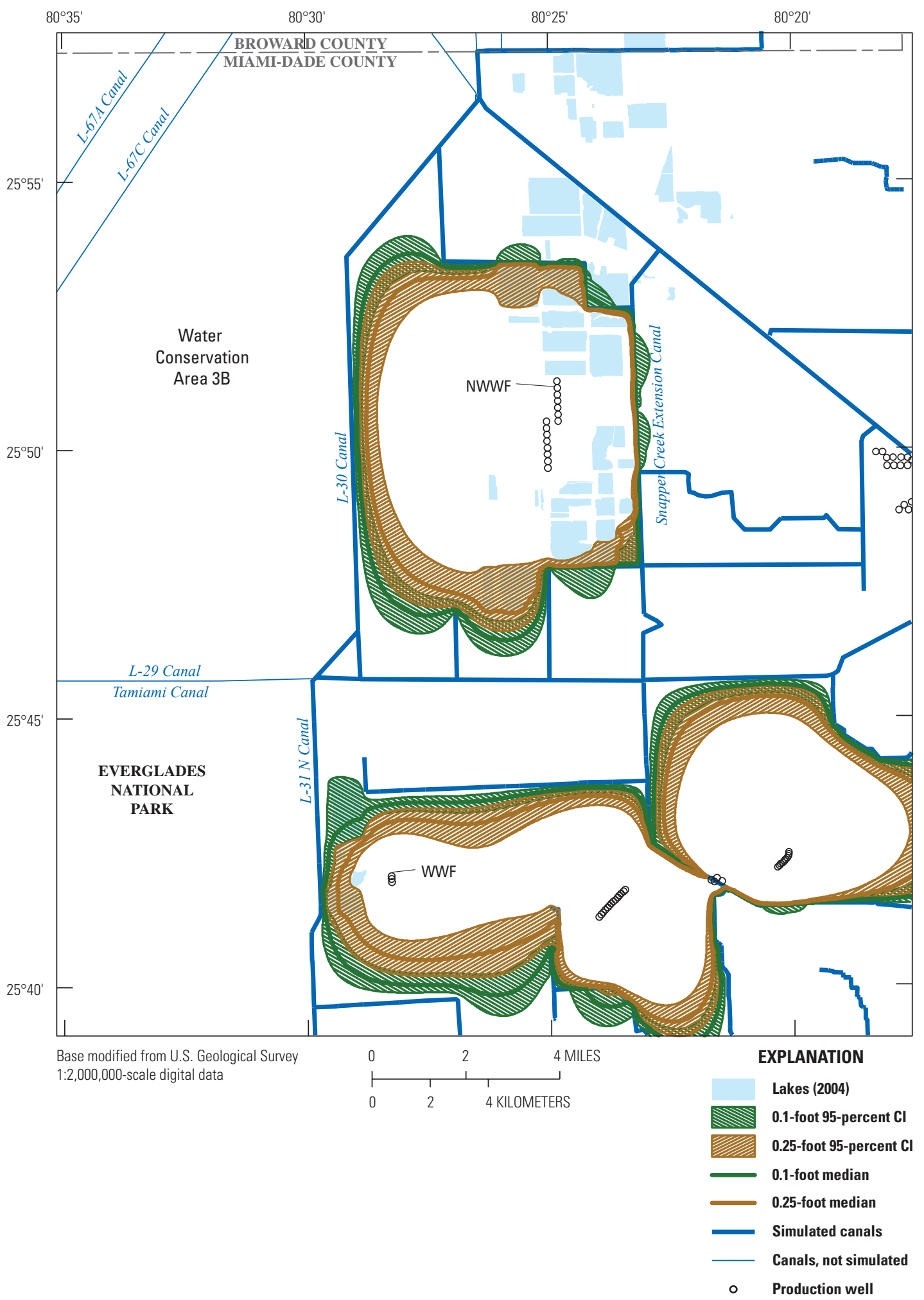

Figure 43. Median and 95-percent confidence intervals ( $\mathrm{Cl}$ ) for 0.1 -foot and 0.25 -foot drawdowns for the Northwest Well Field (NWWF) and West Well Field (WWF) for steady-state, wet conditions. Area shown is Base map 2 (fig. 1). 


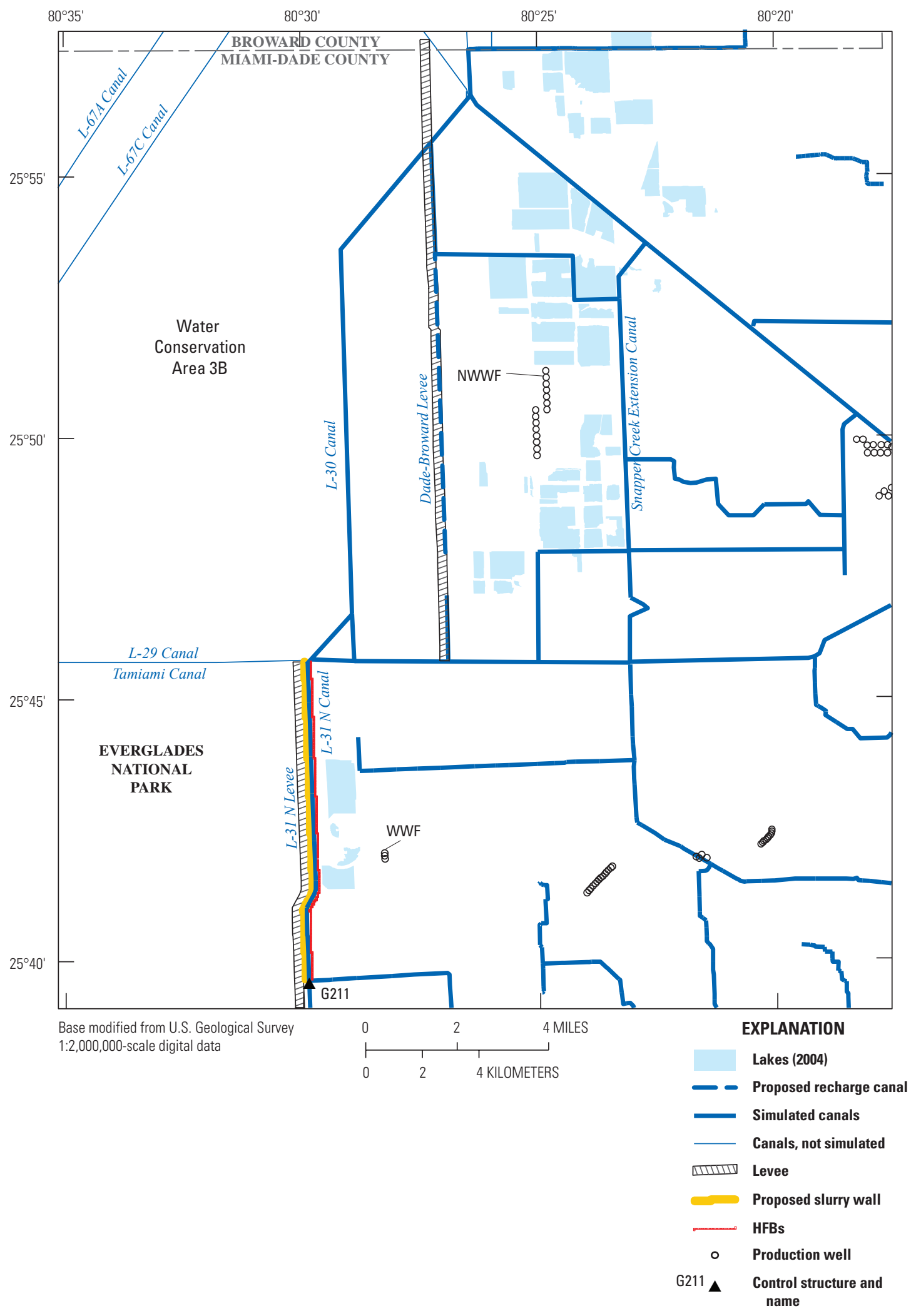

Figure 44. Locations of the recharge canal west of the Northwest Well Field (NWWF), the proposed slurry wall between the L-31N Levee and the L-31N Canal, and the Horizontal Flow Barriers (HFBs) west of the West Well Field (WWF) for Scenario 1. Area shown is Base map 2 (fig. 1). 


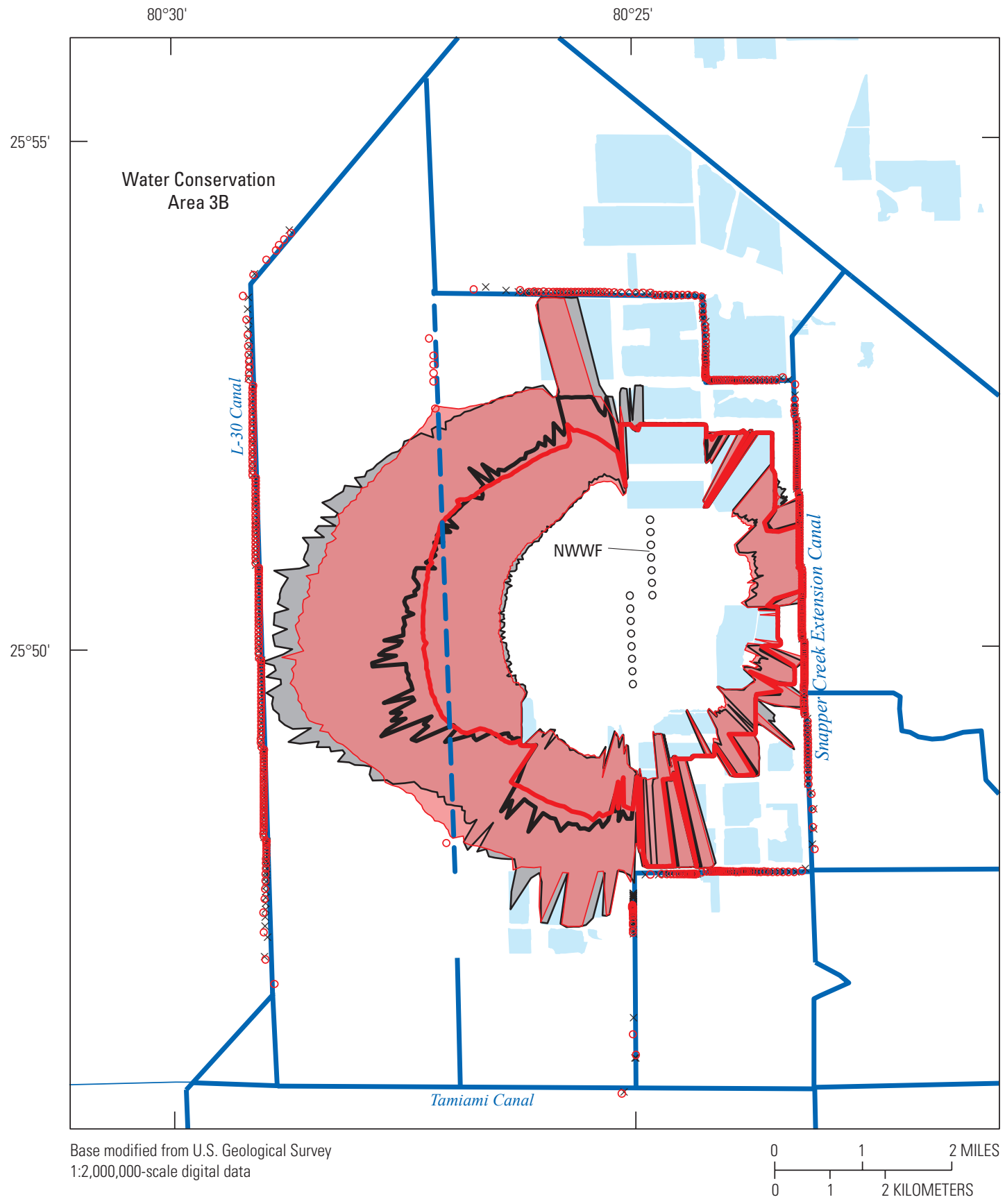

EXPLANATION

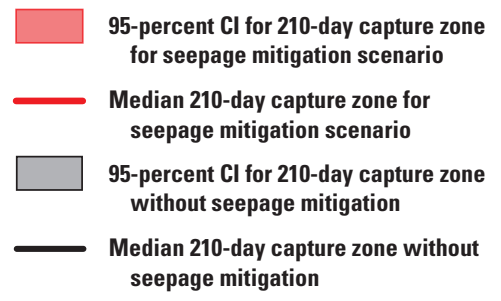

Lakes (2004)

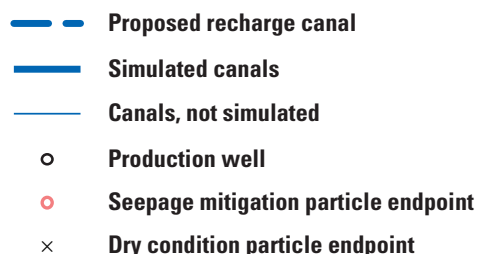

Figure 45. Median and 95-percent confidence intervals for the 210-day capture zones for the Northwest Well Field (NWWF) for steady-state, dry conditions for seepage mitigation scenario and without seepage mitigation, and final particle endpoints for both conditions beyond 210 days. Area shown is Base map 4 (fig. 1). 


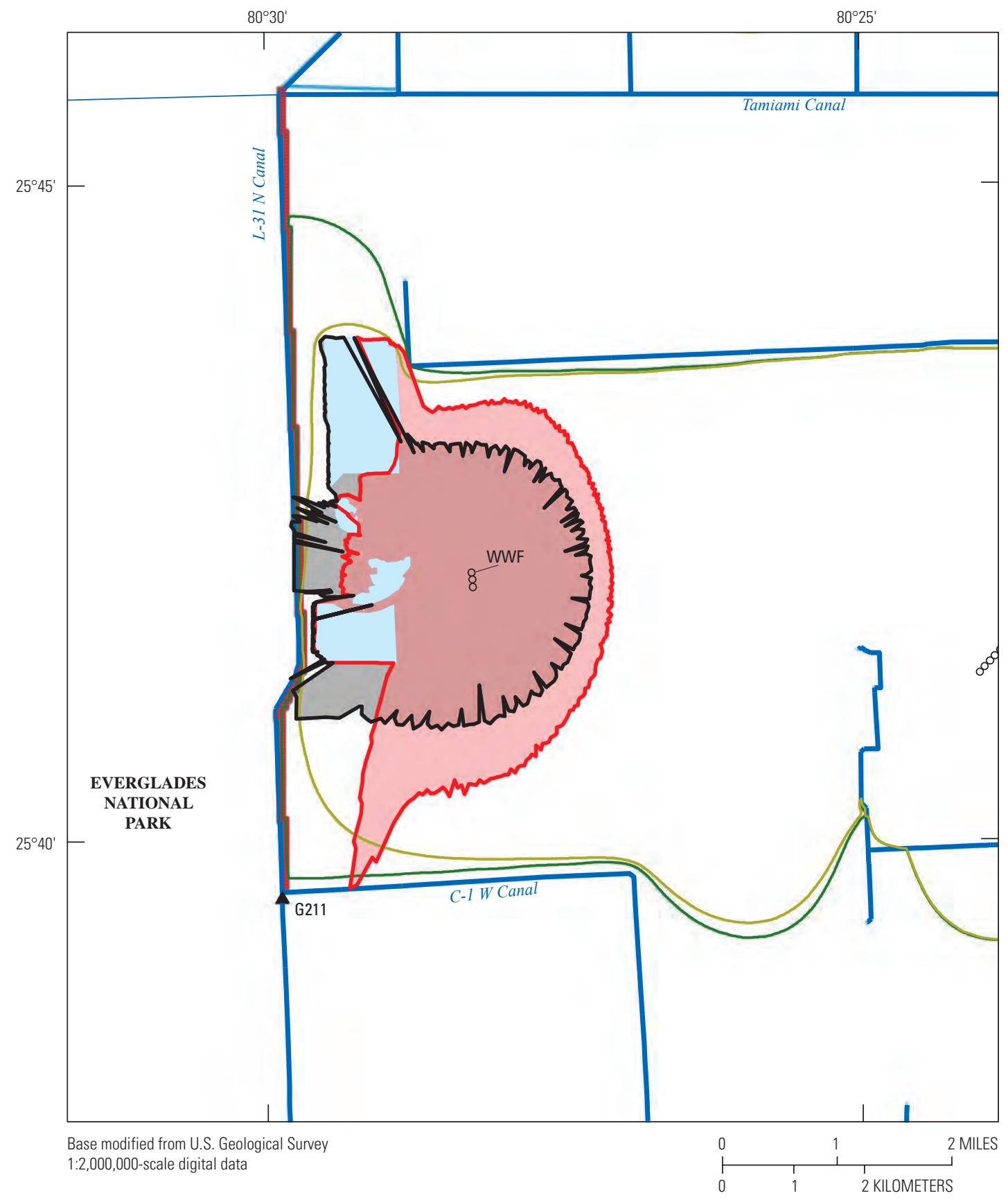

EXPLANATION

\begin{tabular}{|c|c|c|}
\hline $\begin{array}{l}\text { Upper bound of } 95 \text {-percent } \mathrm{Cl} \text { for } 210 \text {-day capture } \\
\text { zone for seepage mitigation scenario }\end{array}$ & & Lakes (2004) \\
\hline $\begin{array}{l}\text { Upper bound of } 95 \text {-percent } \mathrm{Cl} \text { for } 210 \text {-day capture } \\
\text { zone without seepage mitigation }\end{array}$ & & Canals, not simulated \\
\hline Upper bound of the 95-percent $\mathrm{Cl}$ for 0.1 -foot & rmmmmm & HFBs \\
\hline io & $\circ$ & Production well \\
\hline $\begin{array}{l}\text { Upper bound of the 95-percent Cl for } 0.1 \text {-foot } \\
\text { drawdown without seepage mitigation }\end{array}$ & $\mathrm{G} 211 \Delta$ & Control structure an \\
\hline
\end{tabular}

Figure 46. Upper bound of the 95-percent confidence intervals (CI) for the 210-day capture zones and upper bound of the 95-percent $\mathrm{Cl}$ for the 0.1 -foot drawdown for the West Well Field (WWF) for steady-state, dry conditions for seepage mitigation scenario and without seepage mitigation. Area shown is Base map 5 (fig. 1). 


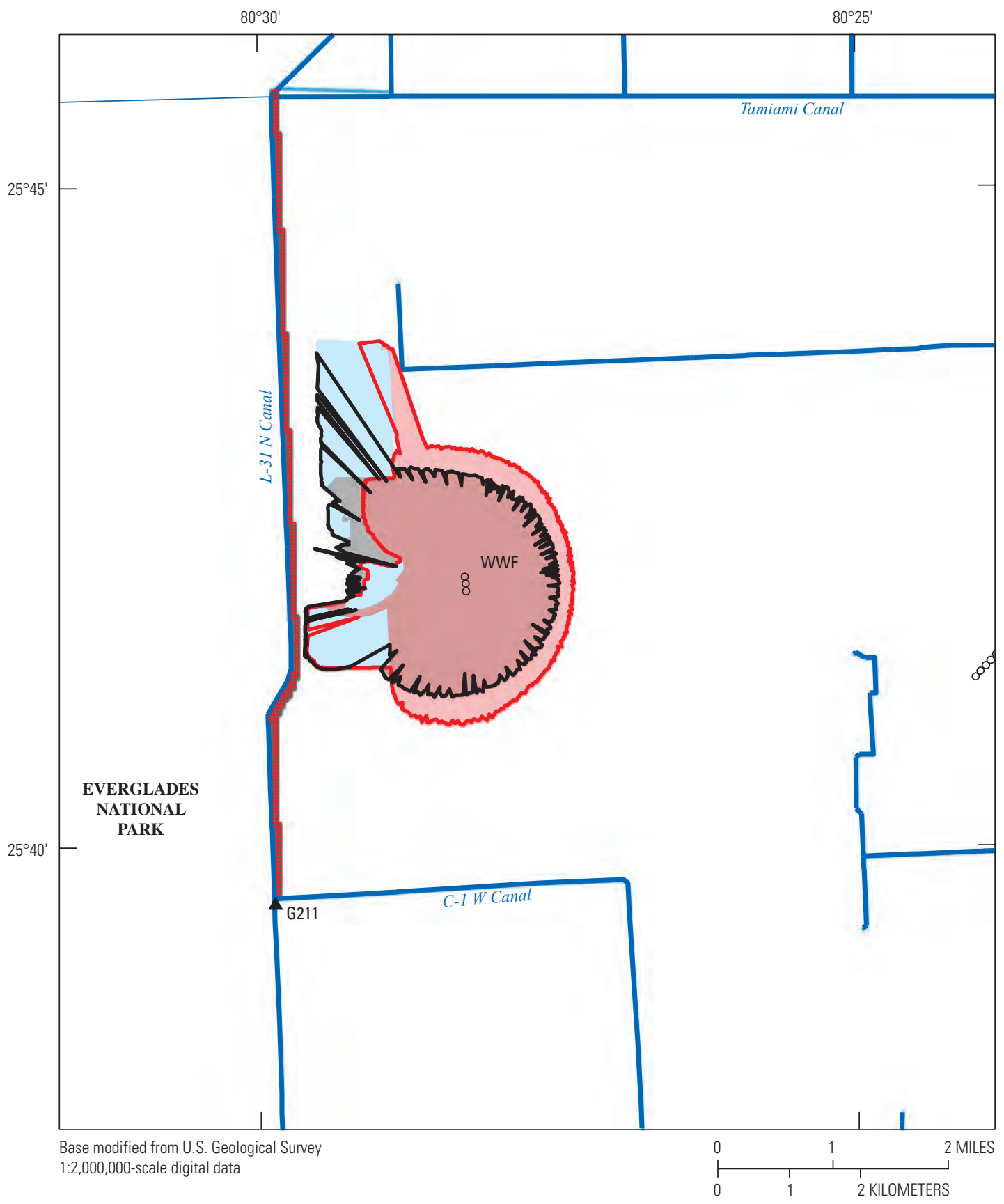

EXPLANATION

Upper bound of 95-percent $\mathrm{Cl}$ for 100-day capture zone for seepage mitigation scenario

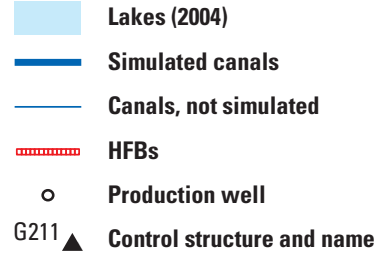

Figure 47. Upper bound of the 95-percent confidence intervals (CI) for the 100-day capture zones for the West Well Field (WWF) for steady-state, dry conditions for seepage mitigation scenario and without seepage mitigation. Area shown is Base map 5 (fig. 1). 


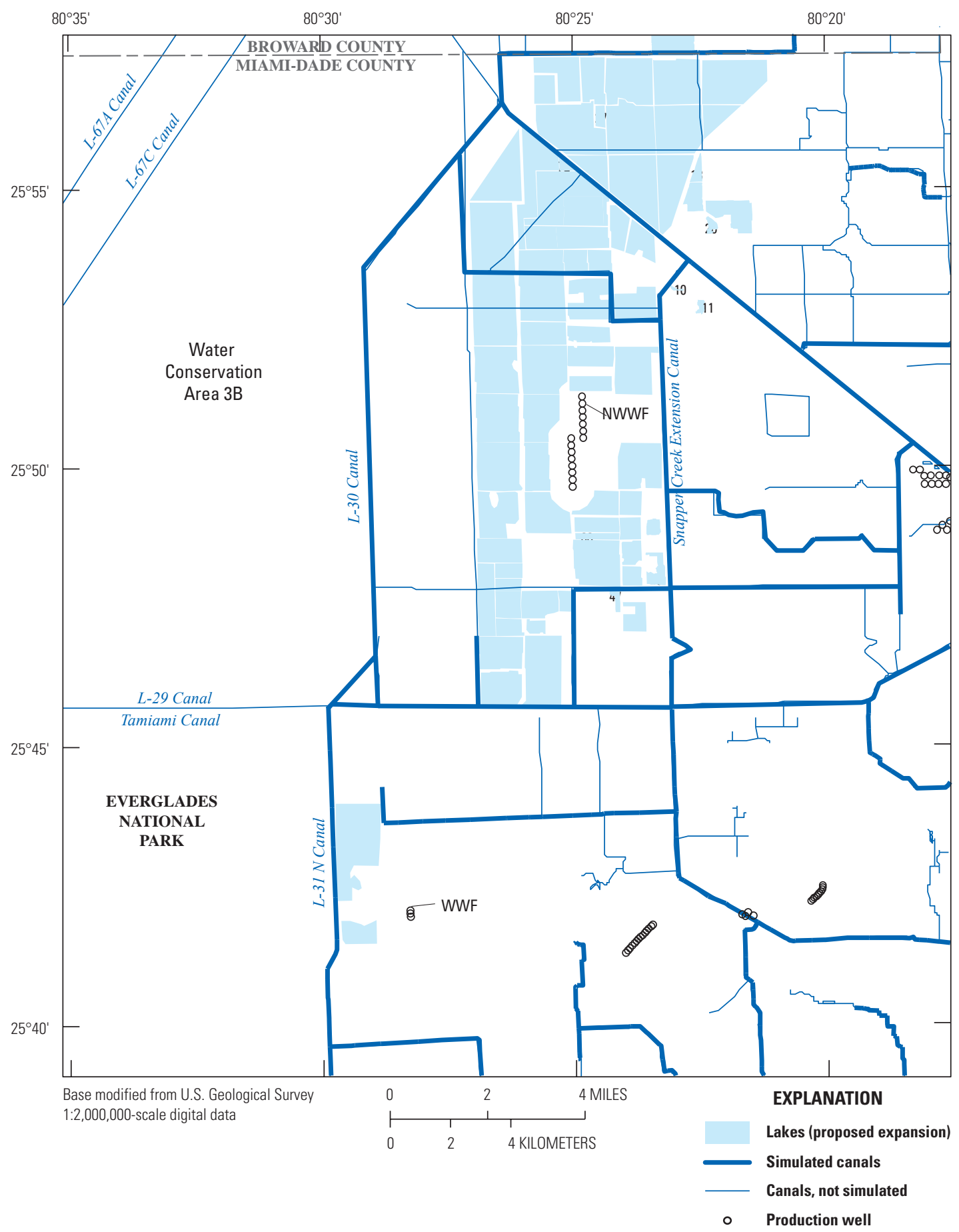

Figure 48. Locations of existing lakes, projected expansion of existing lakes and new proposed lakes for lake-expansion scenario. Area shown is Base map 2 (fig. 1). NWWF is Northwest Well Field. WWF is West Well Field. 


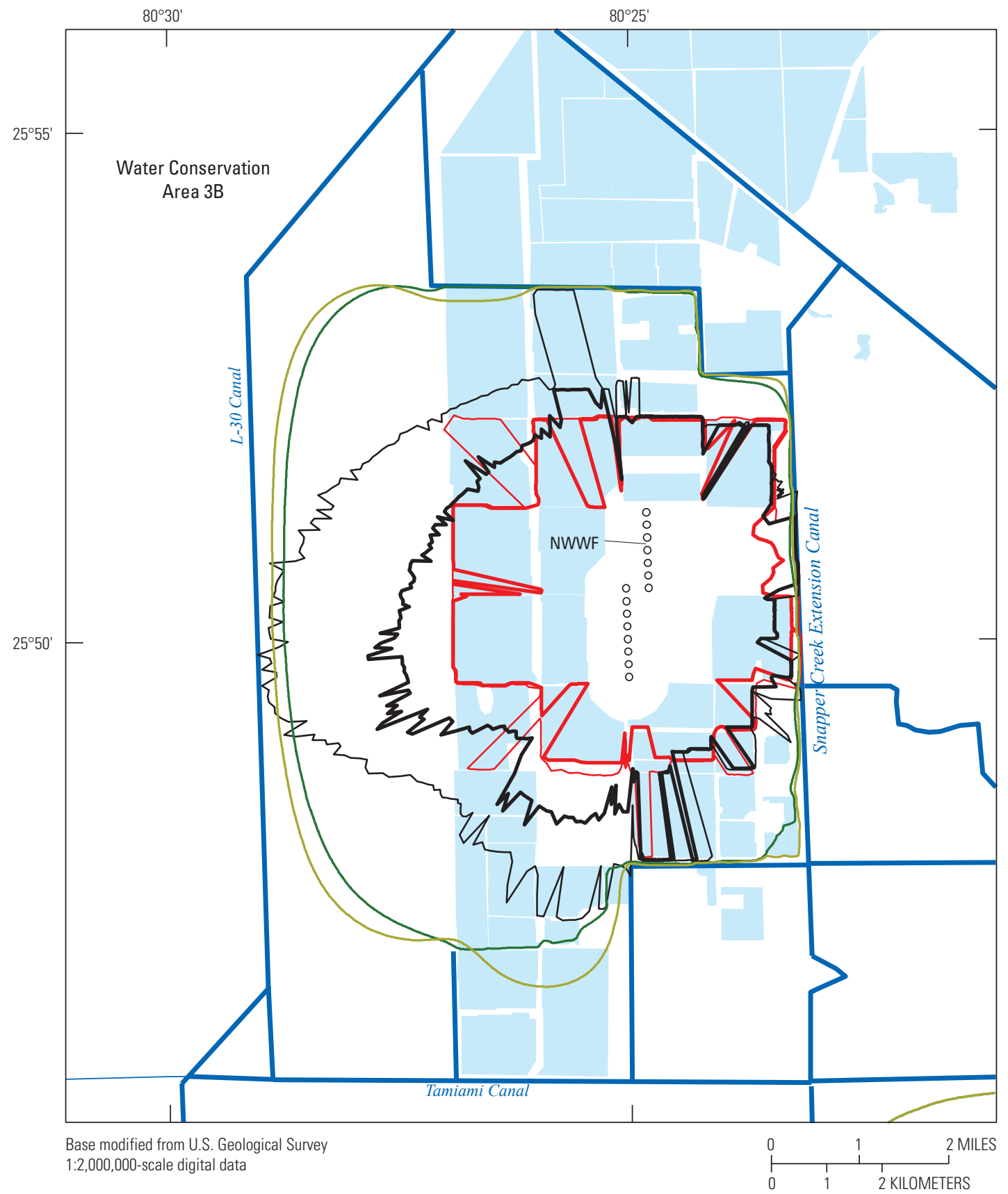

EXPLANATION

Lakes (proposed expansion)

Simulated canals

Canals, not simulated

Upper bound of 95-percent for 210-day capture zone for lake expansion scenario

Upper Bound of 95-percent CI for 210-day capture zone without lake expansion

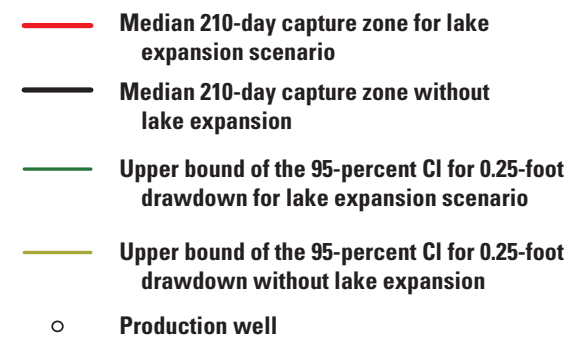

Figure 49. Median and upper bound of the 95-percent confidence intervals (CI) for the 210-day capture zones and upper bound of the 95-percent $\mathrm{Cl}$ for the 0.25-foot drawdown for the Northwest Well Field (NWWF) for steady-state dry conditions for the lake expansion scenario and without lake expansion. Area shown is Base map 4 (fig. 1). 


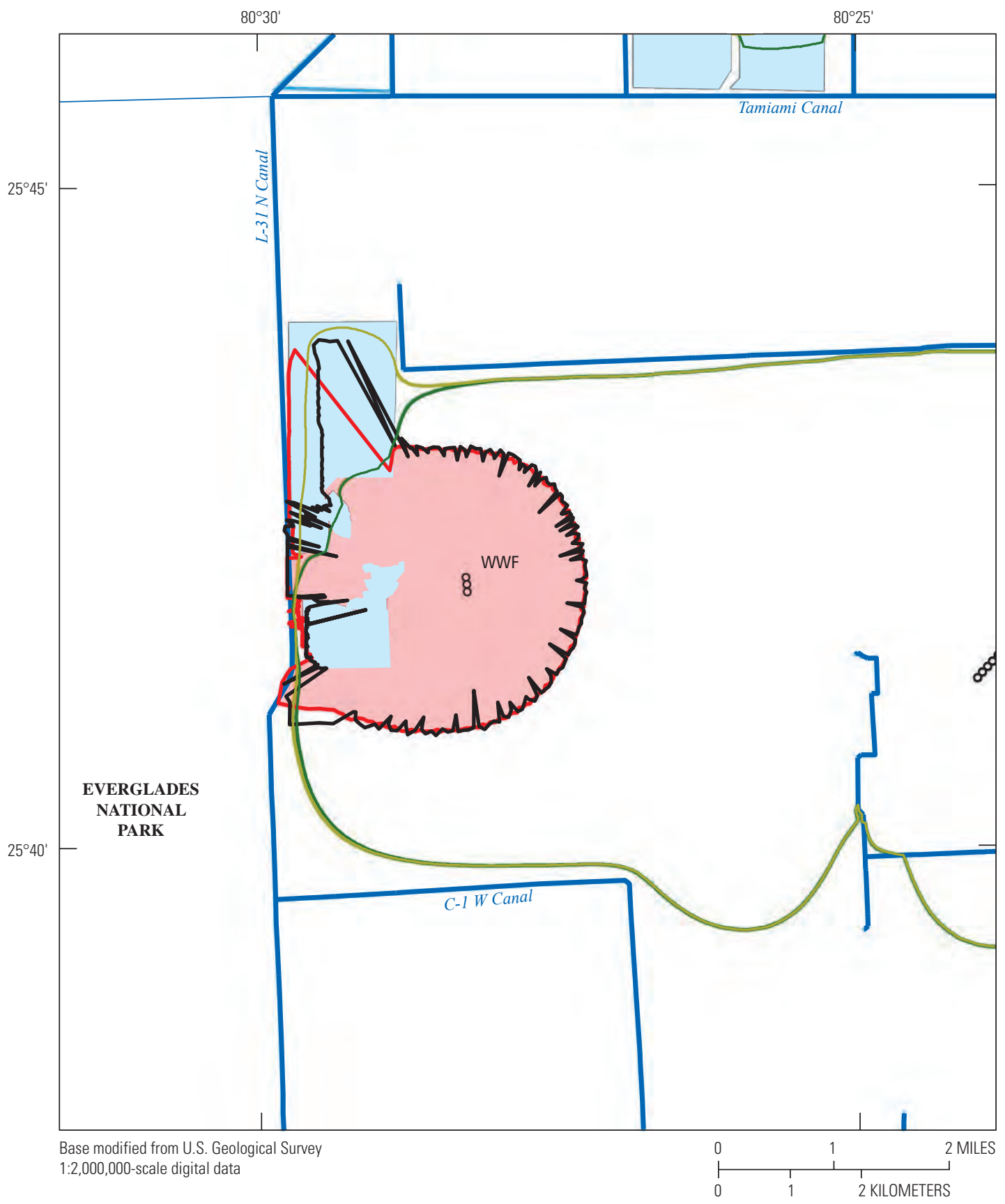

EXPLANATION

Lakes (proposed expansion)

Upper bound of 95-percent Cl for 210-day capture zone for lake expansion scenario

Upper bound of 95-percent $\mathrm{Cl}$ for 210-day capture zone without lake expansion
Upper bound of 95-percent Cl for 0.1-foot drawdown for lake expansion scenario

Upper bound of the 95-percent $\mathrm{Cl}$ for 0.1-foot drawdown without lake expansion

Simulated canals

Canals, not simulated

Production well

Figure 50. Upper bound of the 95-percent confidence intervals (CI) for the 210-day capture zones and upper bound of the 95-percent Cl for the 0.1-foot drawdown for the West Well Field (WWF) for steady-state, dry conditions for the lake expansion scenario and without lake expansion. Area shown is Base map 5 (fig. 1). 


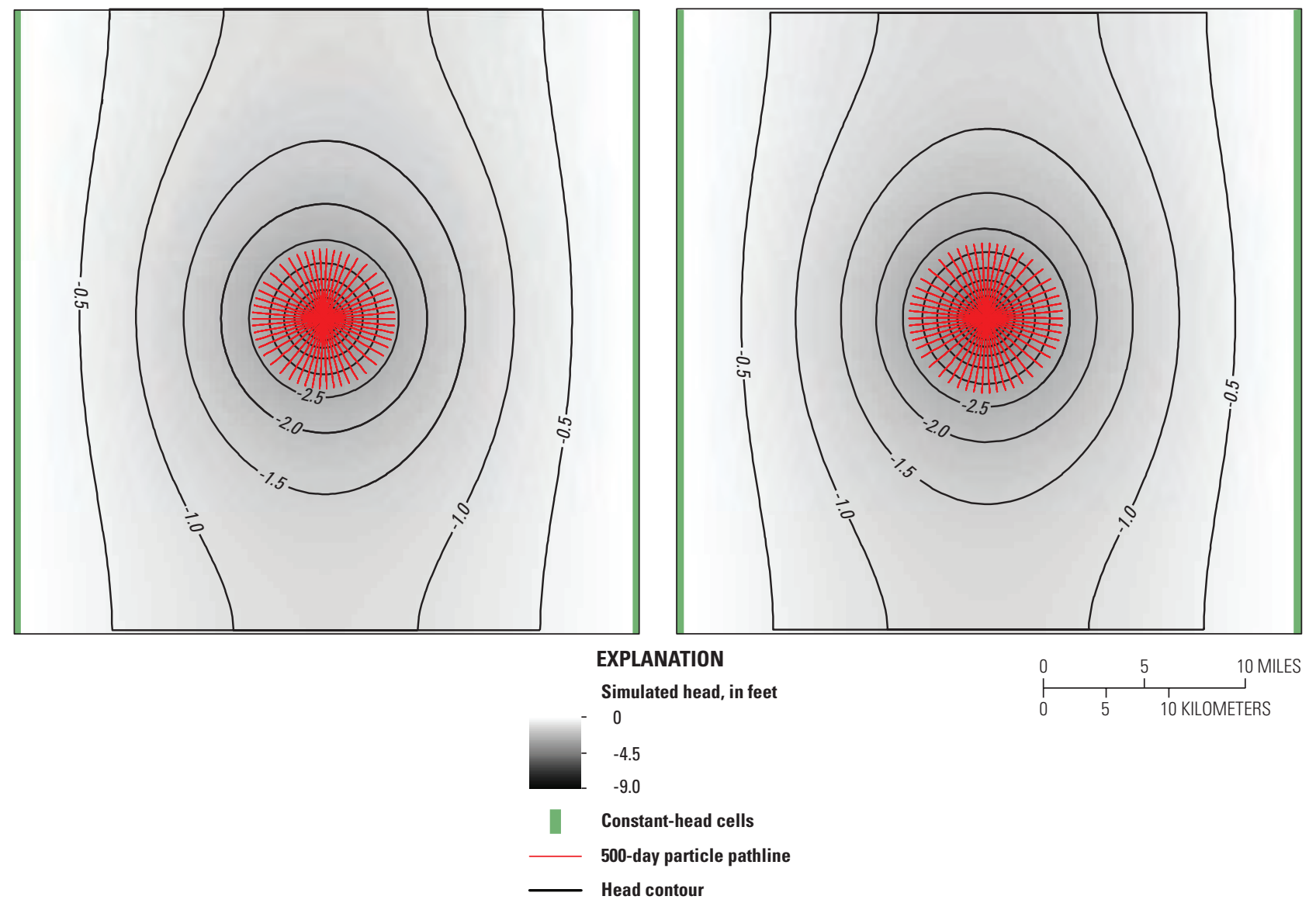

Figure 1-1. Simulated 500-day particle pathlines and head contours for one-layer conceptual Model A (left) and three-layer conceptual Model B (layer 2) (right). 

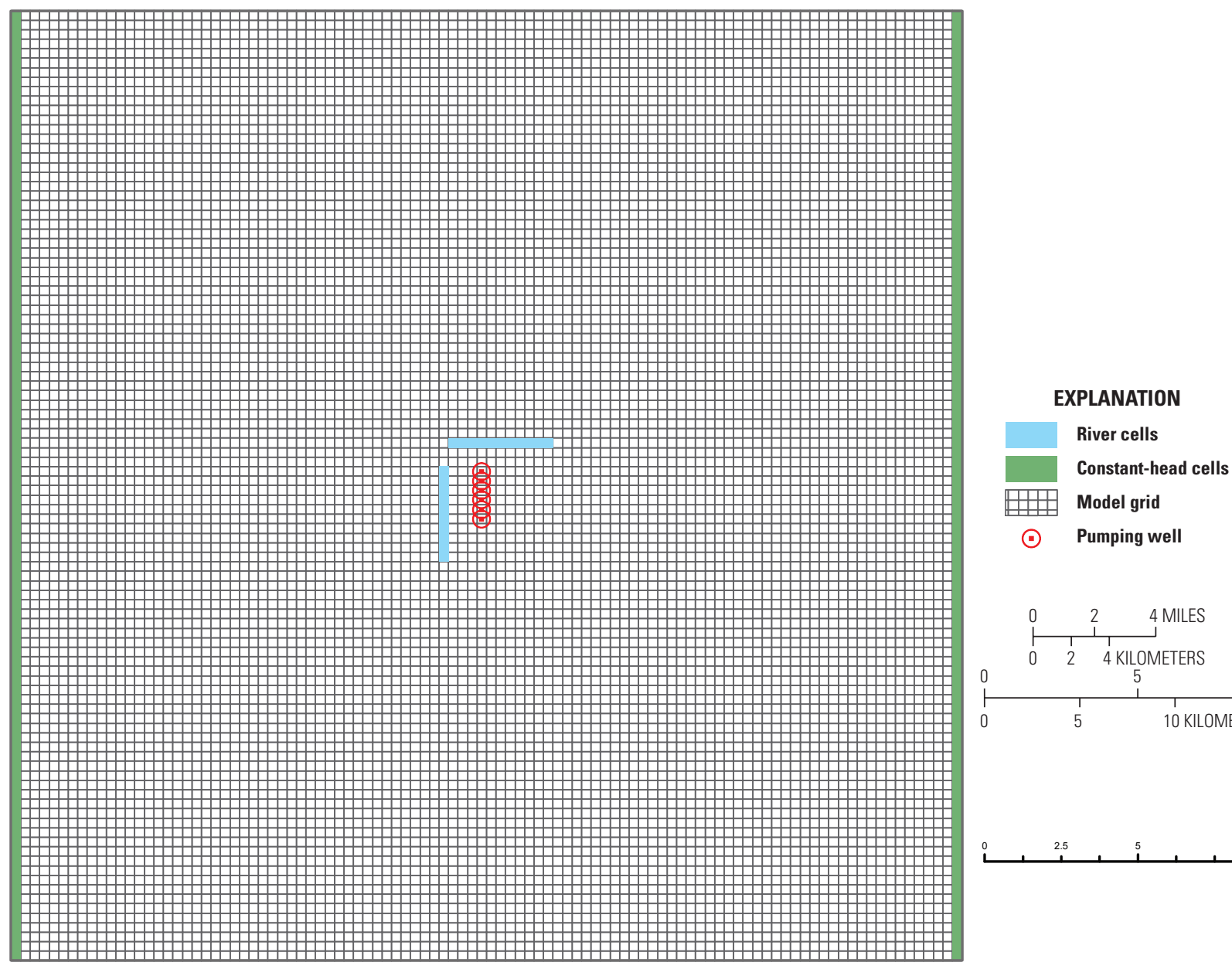

Figure 1-2. Model grid, locations of constant-head cells, river cells and pumping wells for Model A and Model B. 


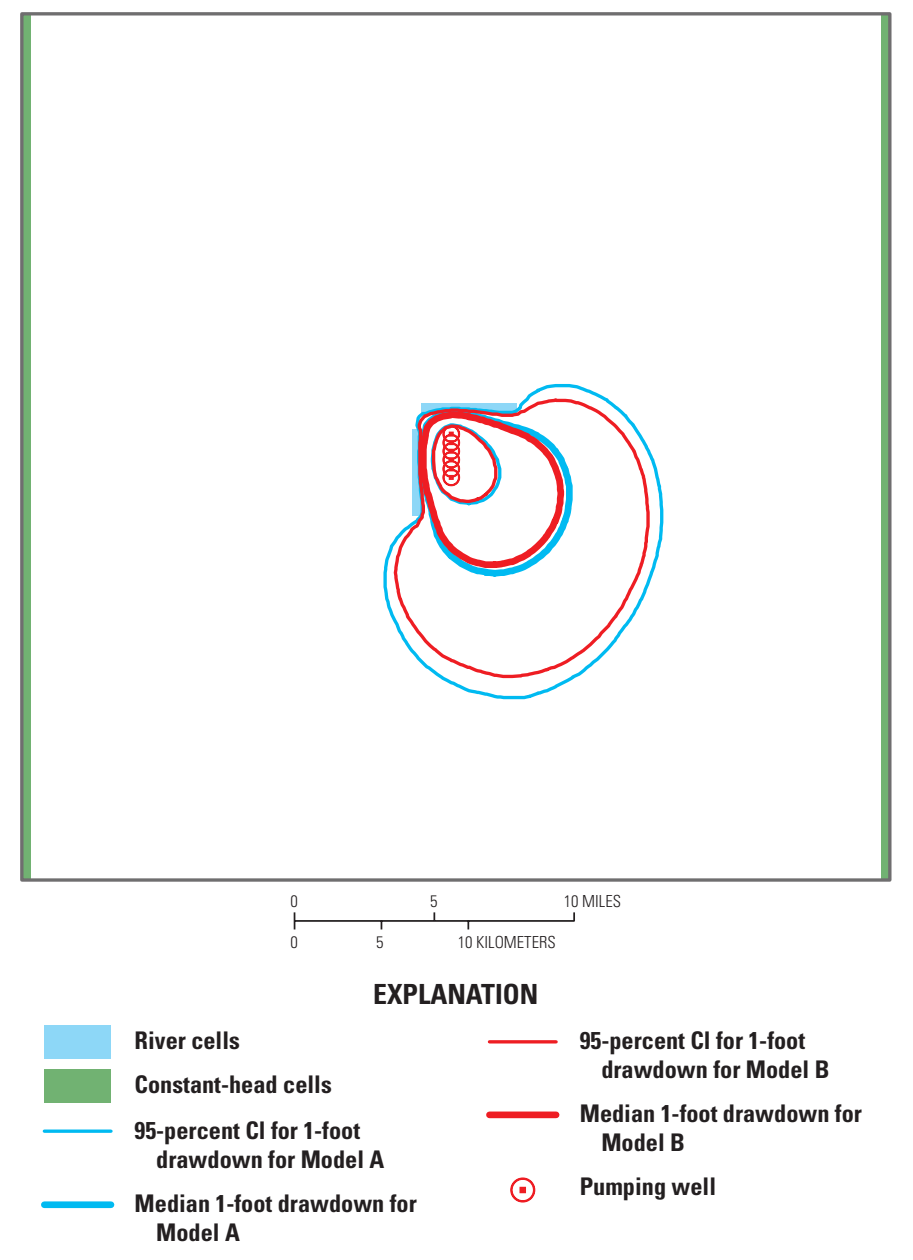

Figure 1-3. Median and 95-percent confidence intervals (CI) for 1-foot drawdown for Model A and Model B. 

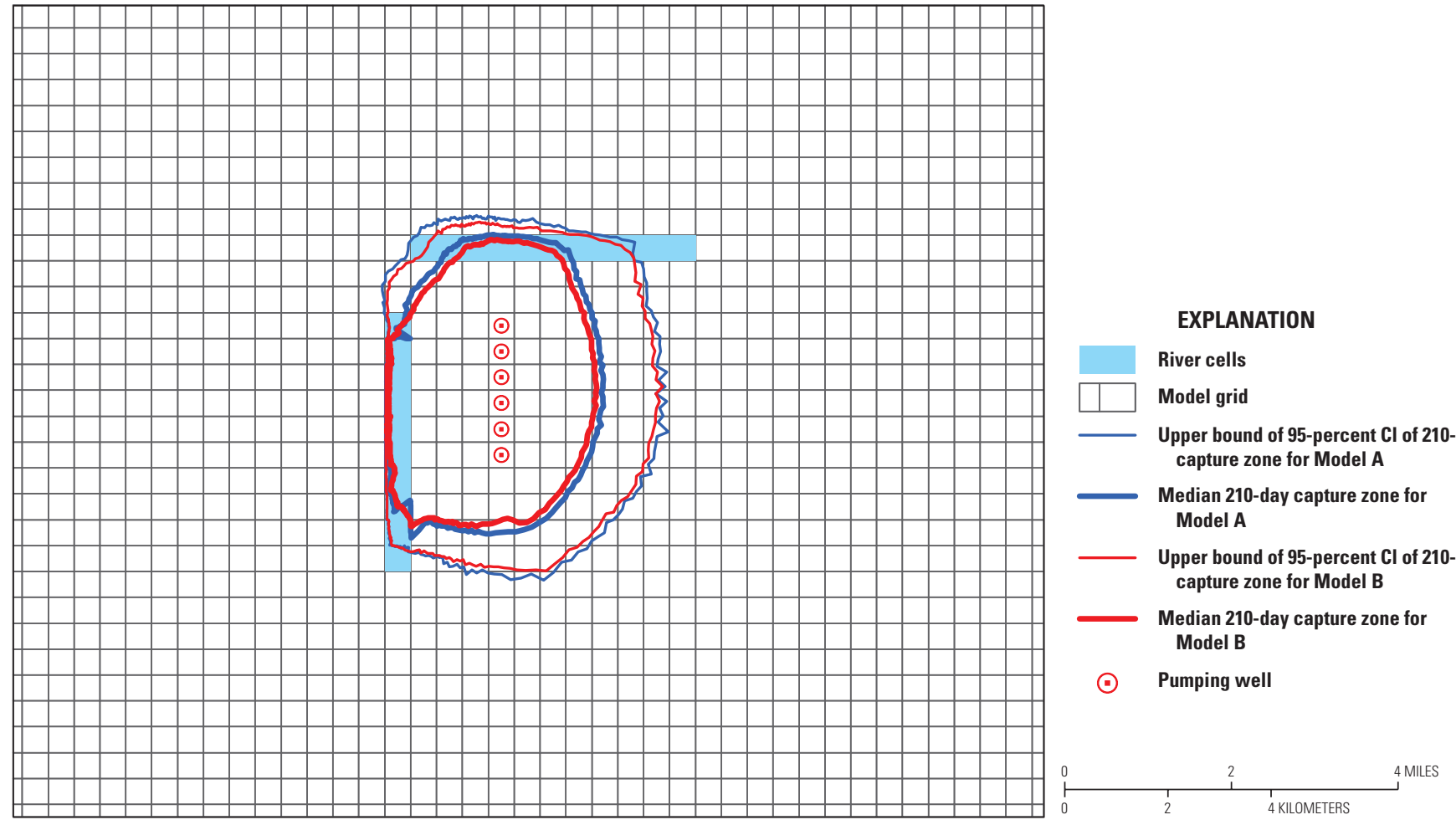

Figure 1-4. Median and upper bound of 95-percent confidence interval (CI) for 210-day capture zones for Model A and Model B. 


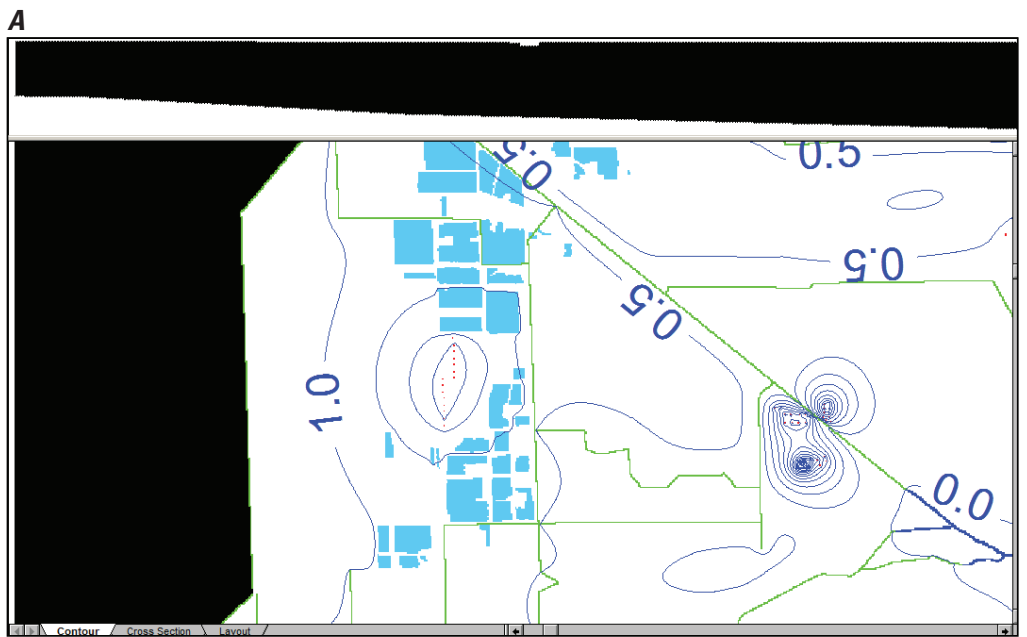

B

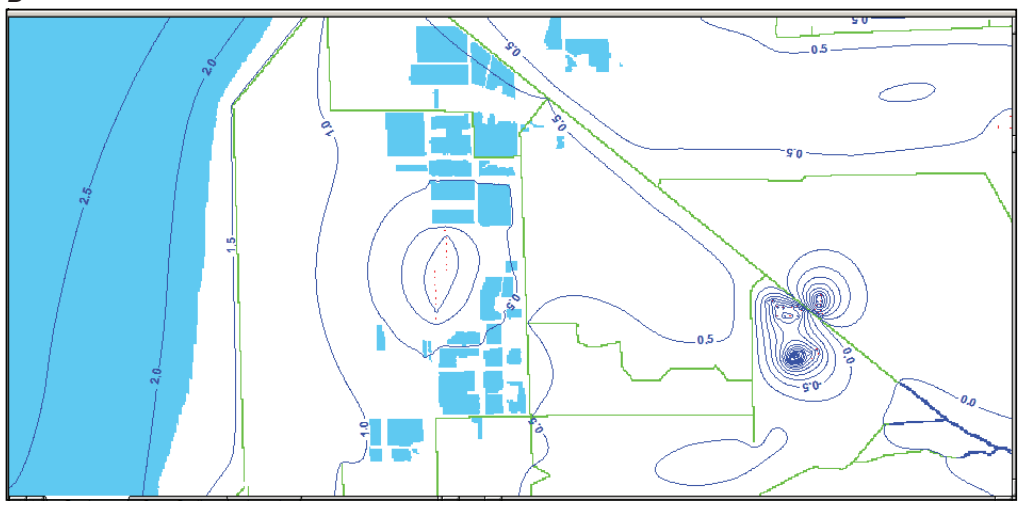

C

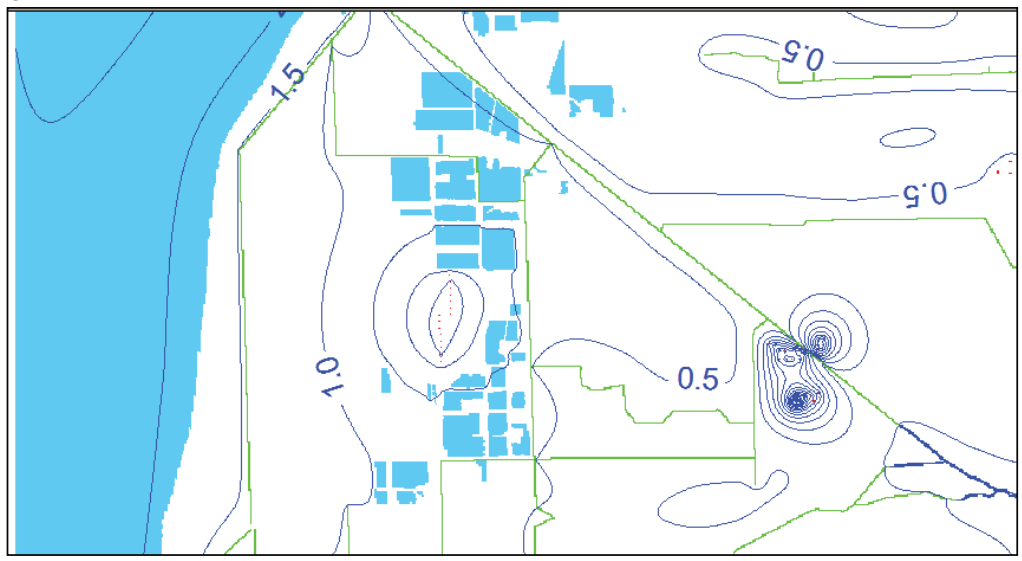

\section{EXPLANATION}

Inactive model cells

Area of standing surface water in Everglades

Water-level contour. contour interval 0.5 foot

_ Simulated canals

Figure 3-1. Simulated water levels for base-case, steady-state average conditions (black area represents inactive model cells) $(A)$ with model boundary as described in the main body of the report, $(B)$ with model boundary extended west of the western canals and general head boundary conductance of 269 square feet per day $\left(\mathrm{ft}^{2} / \mathrm{d}\right)$ (25 square meters per day $\left(\mathrm{m}^{2} / \mathrm{d}\right)$ ), and $(C)$ with model boundary extended west of the western canals and general head boundary conductance of $26,910 \mathrm{ft}^{2} / \mathrm{d}\left(2,500 \mathrm{~m}^{2} / \mathrm{d}\right)$. 



Figure 4-1. Simulated steady-state groundwater head and backward-tracked particle pathlines for $(A)$ the model representing lakes with high hydraulic conductivity and $(B)$ the model using the LAK Package to represent lakes. Lake numbers correspond to data in Table 4-1. 

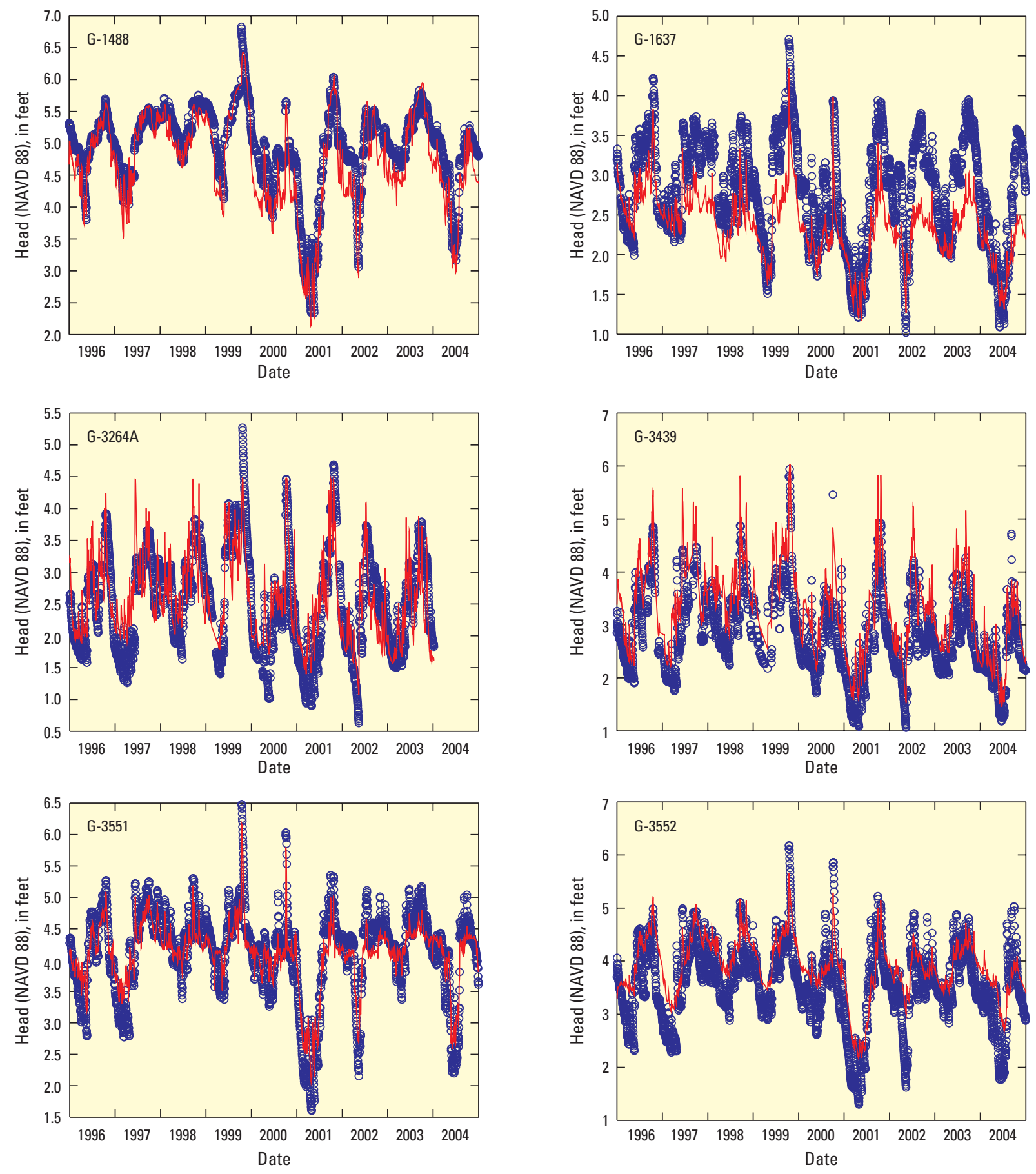

EXPLANATION

Simulated groundwater heads

Observed groundwater heads

Figure 5-1. Daily observed and model-simulated water levels for monitoring wells in the study area not shown in figure 13. 

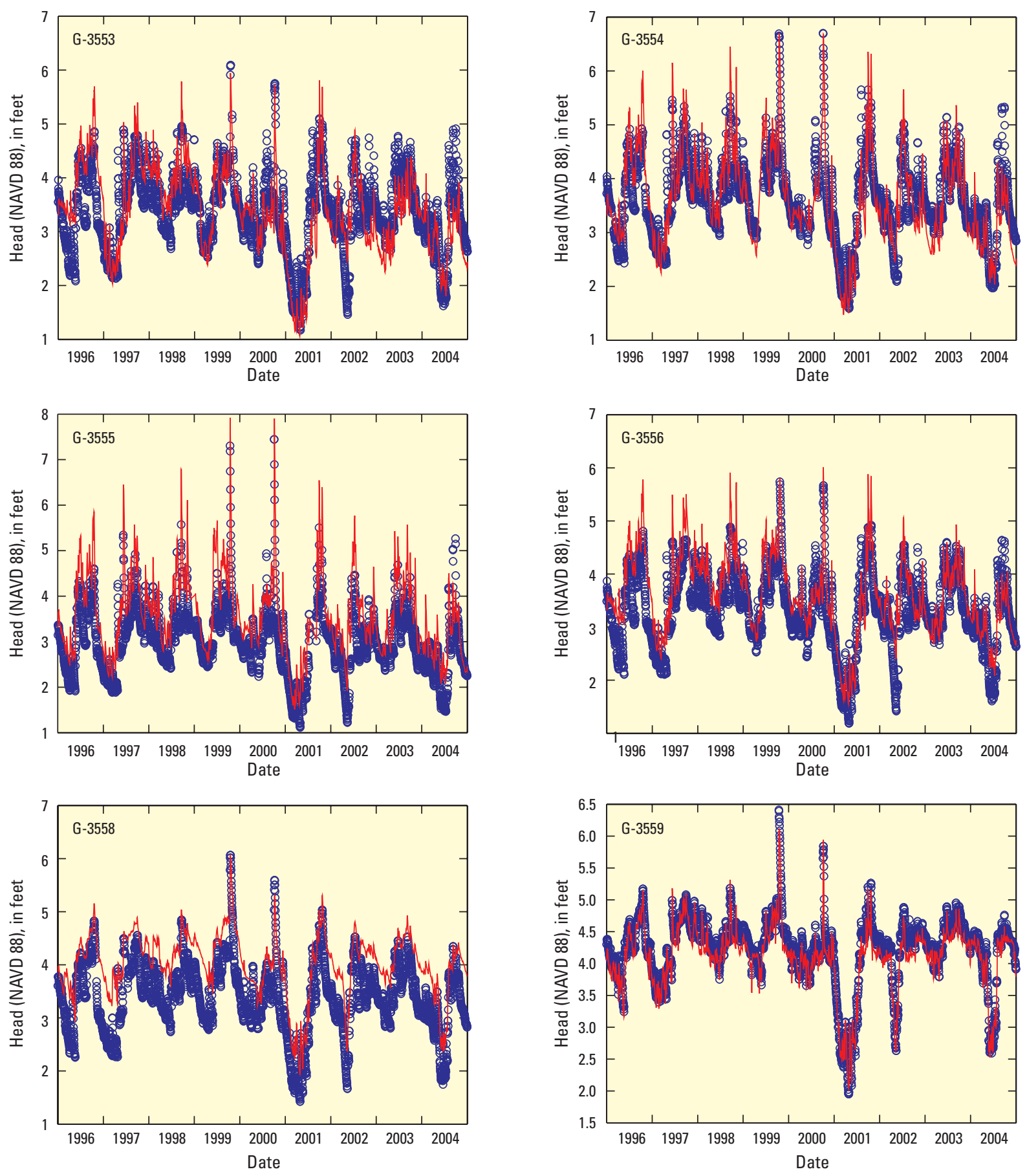

EXPLANATION

Simulated groundwater heads

$\circ$

Observed groundwater heads

Figure 5-1. Daily observed and model-simulated water levels for monitoring wells in the study area not shown in figure 13.-Continued. 

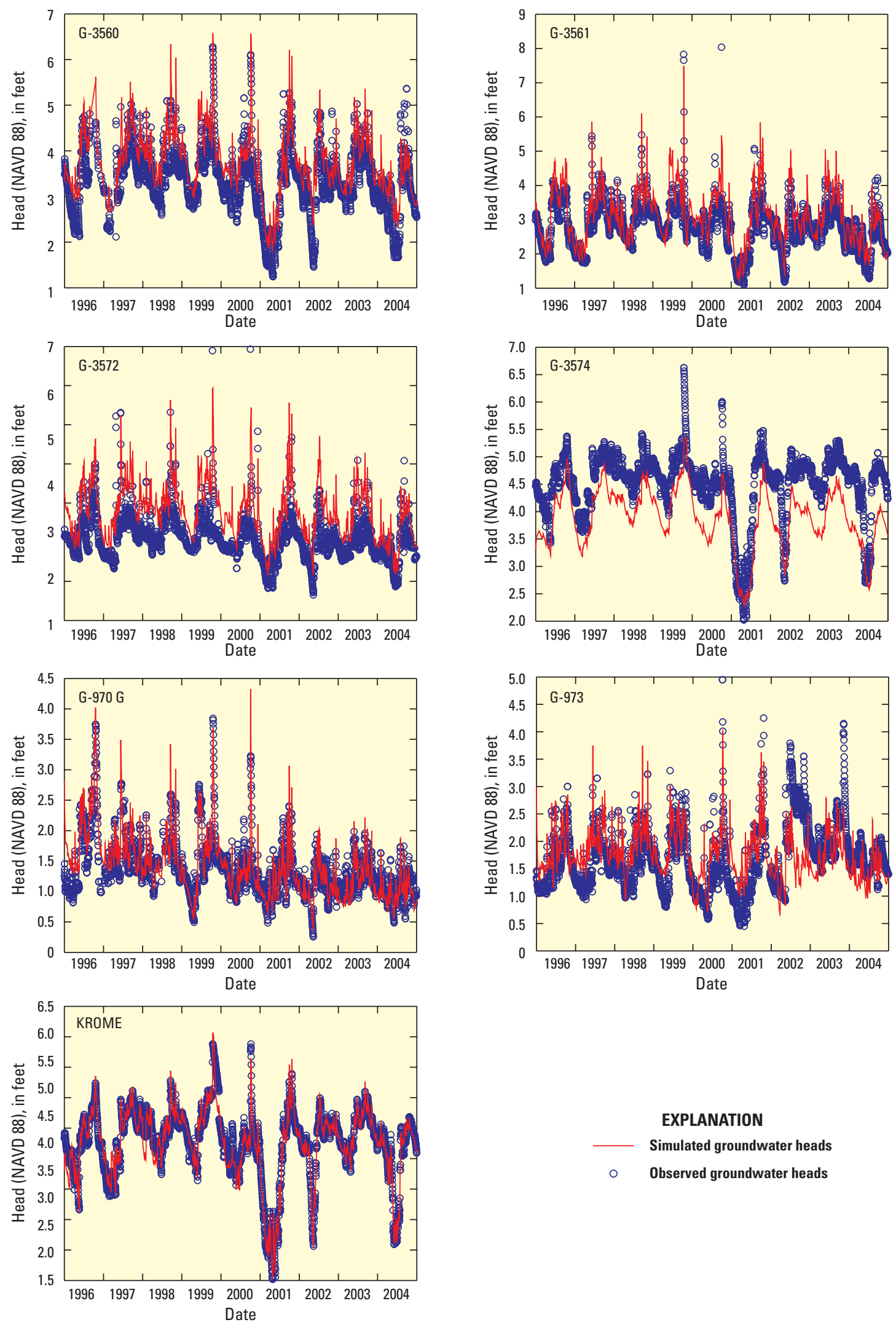

EXPLANATION

Simulated groundwater heads

- Observed groundwater heads

Figure 5-1. Daily observed and model-simulated water levels for monitoring wells in the study area not shown in figure 13.-Continued. 


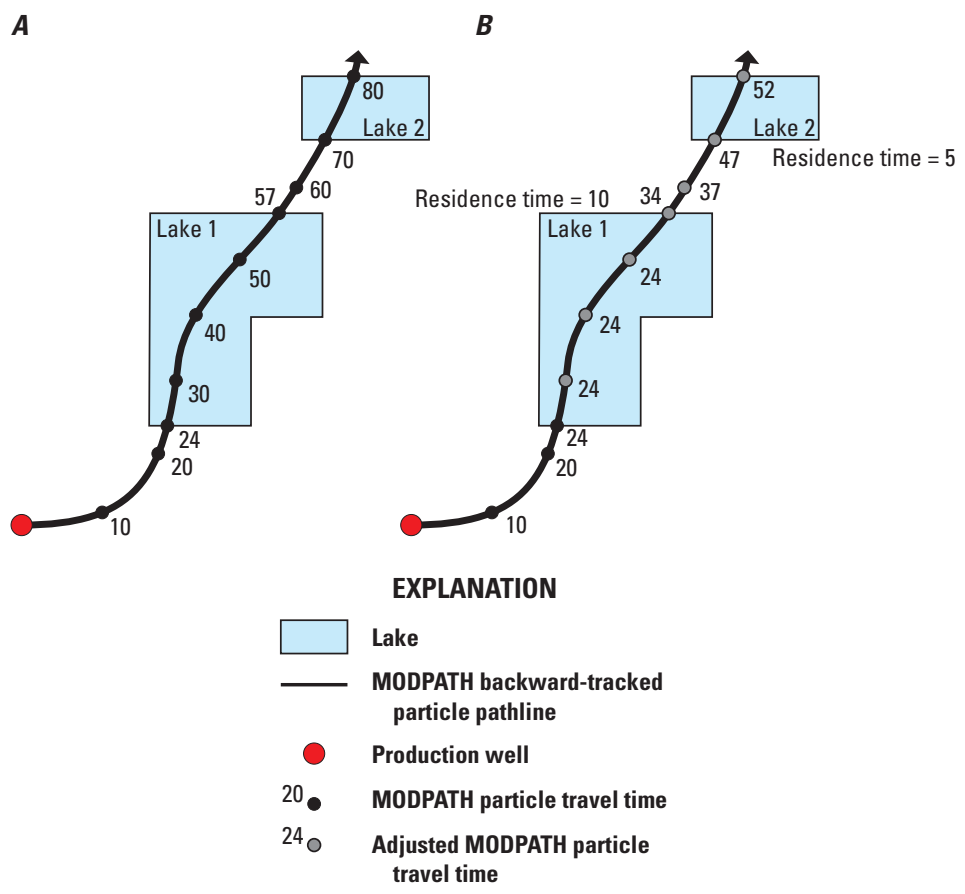

Figure 6-1. Backward-tracked particle pathlines from a pumping well through lakes $(A)$ without residence-time post-processing, $(B)$ with residence-time post-processing. 


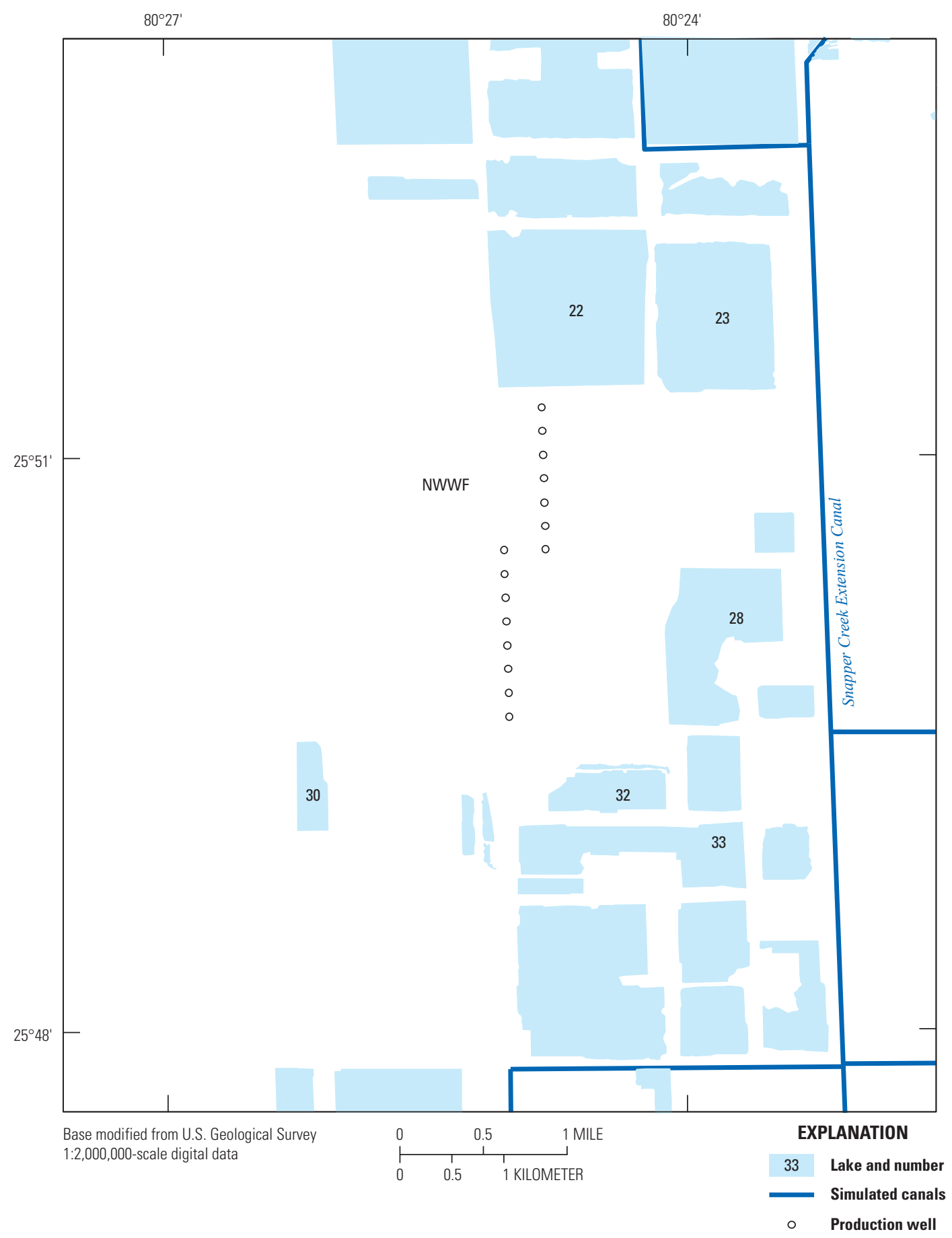

Figure 6-2. Map showing locations and numbering of lakes referred to in paper by Chin and others (2010). Lake numbers correspond to data in Table 6-1. Area shown is Base map 6 (fig. 1). 

Table 1. Monitoring well names, mean errors of head, mean absolute errors of head, and the coefficients of determination of simulated versus observed values of head.

[ME is plotted in figure 14. ME, mean error; MAE, mean absolute error; $\mathrm{R}^{2}$, coefficient of determination]

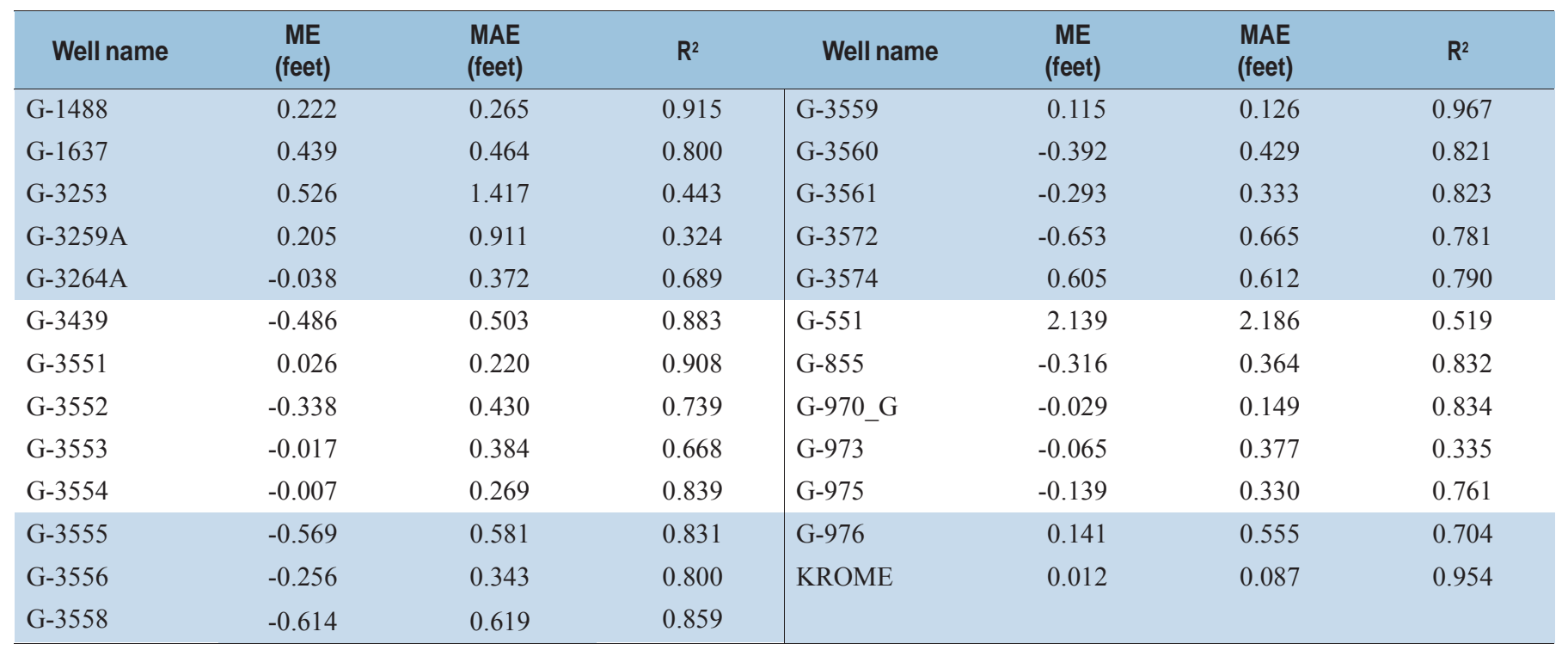


Table 2. Statistics of minimum value and maximum value of hydraulic conductivity for all realizations, prior to calculation of bulk hydraulic conductivities.

[Values shown are in feet per day]

\begin{tabular}{lcc}
\hline \multicolumn{1}{c}{ Descriptor } & $\begin{array}{c}\text { Minimum value for all } \\
\text { realizations }\end{array}$ & $\begin{array}{c}\text { Maximum value for all } \\
\text { realizations }\end{array}$ \\
\hline 2.5-percentile value & 60.5 & 104,205 \\
Median value & 109 & 147,672 \\
97.5-percentile value & 159 & 256,076 \\
\hline
\end{tabular}


Table 4-1. Simulated groundwater inflow, groundwater outflow, and evaporation lake water-budget terms for lakes simulated using the high-hydraulic-conductivity approach and the LAK Package. Lakes are shown in figure 4-1.

[ $\mathrm{ft}^{3} / \mathrm{d}$, cubic foot per day]

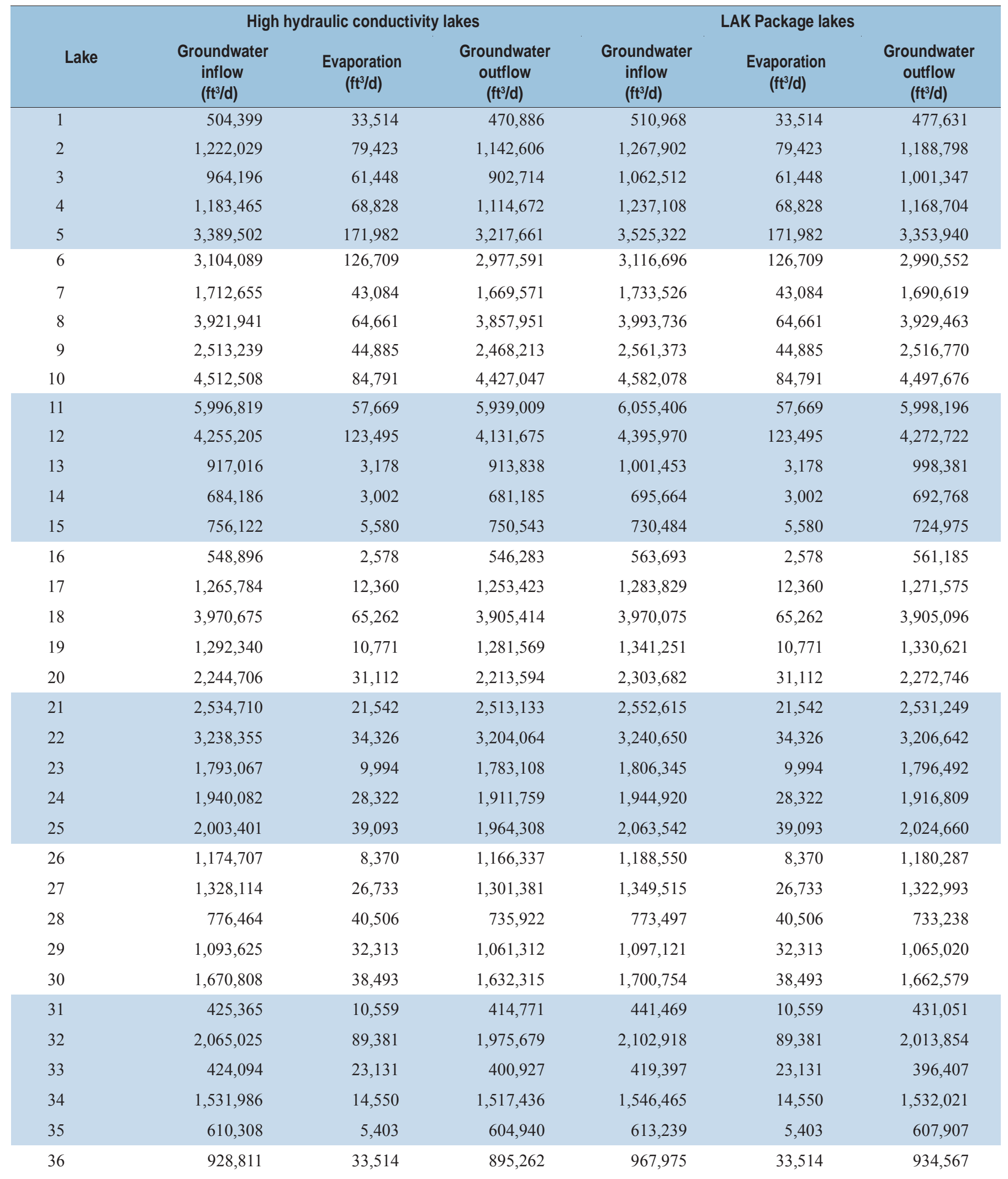


Table 4-1. Simulated groundwater inflow, groundwater outflow, and evaporation lake water-budget terms for lakes simulated using the high-hydraulic-conductivity approach and the LAK Package. Lakes are shown in figure 4-1.-Continued

[ $\mathrm{ft}^{3} / \mathrm{d}$, cubic foot per day]

\begin{tabular}{ccccccc}
\hline Lake & \multicolumn{3}{c}{ High hydraulic conductivity lakes } & \multicolumn{3}{c}{ LAK Package lakes } \\
\cline { 2 - 7 } & $\begin{array}{c}\text { Groundwater } \\
\text { inflow } \\
\left(\mathrm{ft}^{3} / \mathrm{d}\right)\end{array}$ & $\begin{array}{c}\text { Evaporation } \\
\left(\mathrm{ft}^{3} / \mathrm{d}\right)\end{array}$ & $\begin{array}{c}\text { Groundwater } \\
\text { outflow } \\
\left(\mathrm{ft}^{3} / \mathrm{d}\right)\end{array}$ & $\begin{array}{c}\text { Groundwater } \\
\text { inflow } \\
\left(\mathrm{ft}^{3} / \mathrm{d}\right)\end{array}$ & $\begin{array}{c}\text { Evaporation } \\
\left(\mathrm{ft}^{3} / \mathrm{d}\right)\end{array}$ & $\begin{array}{c}\text { Groundwater } \\
\text { outflow } \\
\left(\mathrm{ft}^{3} / \mathrm{d}\right)\end{array}$ \\
\hline 37 & $1,687,264$ & 89,381 & $1,597,883$ & $1,745,604$ & 89,381 & $1,656,646$ \\
38 & 678,607 & 16,351 & 662,221 & 696,864 & 16,351 & 680,549 \\
Sum & $70,864,529$ & $1,656,470$ & $69,208,059$ & $72,184,168$ & $1,656,470$ & $70,536,738$ \\
\hline
\end{tabular}


Table 6-1. Residence times used in model documented in this report and those calculated by Chin and others (2010). Lakes are shown in figure 6-2.

\begin{tabular}{ccc}
\hline \multirow{2}{*}{$\begin{array}{c}\text { Lake } \\
\text { number }\end{array}$} & \multicolumn{2}{c}{ Residence time (days) } \\
\cline { 2 - 3 } & This study & Chin and others (2010) \\
\hline 22 & 239 & 314 \\
23 & 325 & 1,290 \\
28 & 115 & 259 \\
30 & 165 & 88 \\
32 & 73 & 87 \\
33 & 99 & 159 \\
\hline
\end{tabular}






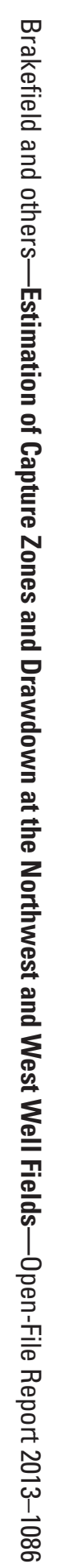

